\title{
Aplicação de Técnicas de Inteligência Artificial no Planejamento da Operação de Sistemas Hidrotérmicos de Potência
}

\author{
Patricia Teixeira Leite
}

Tese apresentada à Escola de Engenharia de São Carlos da Universidade de São Paulo, como parte dos requisitos para obtenção do título de Doutora em Engenharia Elétrica

Orientador: Prof. Dr. Adriano Alber de França Mendes Carneiro

Co-orientador: Prof. Dr. André Carlos Ponce de Leon Ferreira de Carvalho 
Dedicatória

Dedico este trabalho aos meus pais,

Elicrisio e Ângela, e aos meus irmãos,

Weliton, Elisângela e Daniela,

pelo incentivo e carinho. 
Ao Prof. Dr. Adriano Alber de França Mendes Carneiro pela excelente orientação, pela amizade e incentivo em todos os momentos.

Ao Prof. Dr. André Carlos Ponce de Leon Ferreira de Carvalho pelo incentivo, amizade e confiança me co-orientando neste trabalho e também à sua família pela assistência, durante o meu Doutorado Sanduíche no Canadá.

Ao Prof. Dr. Sadao Massago pela amizade, apoio no desenvolvimento computacional desta pesquisa.

Aos amigos, Maristela, Luiza, Mário e a Prof. Ângela pela infinita paciência e pelo incansável apoio durante o desenvolvimento deste trabalho.

As amigas da Cozinha Natural, Meire, Karla, Kátia, Ana Rita, Renata, Luciana, Natache, Aline, Franklina e Sarita, pelo momentos de alegria e descontração.

Aos amigos de São Carlos, Cuiabá, alunos do LSEE I e II, João Bosco, Guilherme, Arthur, Marcelo Rosa, Marcos, Nilson, e todos os outros que não foram aqui mencionados, por tudo.

Aos professores e funcionários do Departamento de Engenharia Elétrica da Escola de Engenharia de São Carlos, do Instituto de Ciências Matemáticas e de Computação de São Carlos e ao Departamento de Computação da Universidade de Guelph, que de forma direta ou indireta participaram do desenvolvimento deste trabalho.

À Fundação de Amparo à Pesquisa do Estado de São Paulo (FAPESP) pelo suporte financeiro fornecido para a realização deste trabalho (Processo No. 99/01710-2) e à apreciação técnica anônima prestada por parte da assessoria científica da mesma. 


\section{Sumário}

Lista de Figuras vi

Lista de Tabelas

Lista de Abreviaturas e Siglas xii

Lista de Símbolos $\quad$ xiv

Resumo xvi

Abstract $\quad$ xvii

1 Introdução 1

1.1 Contribuições desta Tese . . . . . . . . . . . . . . . . 3

1.2 Organização Geral deste Documento . . . . . . . . . . . . . . . 4

1.3 Artigos Publicados . . . . . . . . . . . . . . . . . 5

2 O Planejamento da Operação $\quad 8$

2.1 Introdução . . . . . . . . . . . . . . . . . . . . . . . 8

2.2 Características dos Sistemas Energéticos em Alguns Países . . . . . . . . 12

2.3 Parâmetros de Uma Usina Hidroelétrica . . . . . . . . . . . . . . . . . . 14

2.4 Formulação Matemática do Problema . . . . . . . . . . . . . . 15

2.5 Revisão Bibliográfica . . . . . . . . . . . . . . . . . . 22

3 Algoritmos Genéticos $\quad 28$

3.1 Introdução . . . . . . . . . . . . . . . . . . . . . . . 28

3.2 Histórico . . . . . . . . . . . . . . . . . . . . . . . 31

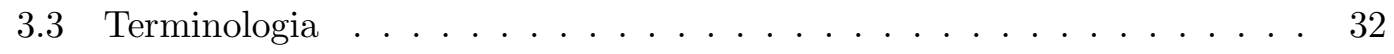

3.4 Características gerais e representação . . . . . . . . . . . . . 34

3.5 Seleção . . . . . . . . . . . . . . . . . . . . . 35

3.6 Operadores Genéticos . . . . . . . . . . . . . . . 36 
4 Adaptação dos Algoritmos Genéticos ao POSHP 41

4.1 Introdução . . . . . . . . . . . . . . . . . . . . . . . . . . . . 41

4.2 Algoritmo Proposto . . . . . . . . . . . . . . . . . . . . 42

4.3 Estudo . . . . . . . . . . . . . . . . . . . . . 62

4.3 .1 Uma usina isolada . . . . . . . . . . . . . . . . . 66

4.3.2 Três usinas em cascata . . . . . . . . . . . . . . . . 67

4.3 .3 Sete usinas em cascata . . . . . . . . . . . . . . . . 68

5 Aprimoramento dos Parâmetros Utilizados $\quad \mathbf{7 0}$

5.1 Introdução . . . . . . . . . . . . . . . . . . . . . . . . . . 70

5.1 .1 Tamanho da população e solução inicial . . . . . . . . . . . . 73

5.1 .2 Teste de hipótese . . . . . . . . . . . . . . . . . . . . . . 74

5.1 .3 Aplicação do teste de hipótese . . . . . . . . . . . . . . 76

5.1 .4 Ponderação dos operadores genéticos . . . . . . . . . . . . 81

6 Aplicações no Sistema Brasileiro $\quad 85$

6.1 Intodução . . . . . . . . . . . . . . . . . . . . . . . . 85

6.2 Estudo I . . . . . . . . . . . . . . . . . . . . . . . . 87

6.3 Estudo II . . . . . . . . . . . . . . . . . . . . . . . . . . . 89

6.4 Estudo III . . . . . . . . . . . . . . . . . . . . . . . . . . . . . . 91

6.5 Estudo IV . . . . . . . . . . . . . . . . . . . . . . . . . . . 92

6.5.1 Teste 1 - Afluência igual a MLT . . . . . . . . . . . . . . . 92

6.5.2 Teste 2 - Afluência igual a $80 \%$ da MLT . . . . . . . . . . . . . 97

6.5.3 Teste 3 - Afluência igual ao período do histórico de 1947 a 1949 . 99

6.5.4 Teste 4 - Afluência igual ao período do histórico de 1953 a 1955 . 100

6.6 Estudo V . . . . . . . . . . . . . . . . . . . . . . . . . 101

6.6.1 Teste 1 - Afluência igual a MLT . . . . . . . . . . . . . . . 101

6.6.2 Teste 2 - Afluência igual a $80 \%$ da MLT . . . . . . . . . . 105

6.6.3 Teste 3 - Afluência do período histórico de 1947 a 1949 . . . . . 110

$\begin{array}{llr}7 & \text { Conclusões } & 115\end{array}$

7.1 Trabalhos Futuros . . . . . . . . . . . . . . . . 116

$\begin{array}{ll}\text { A Algoritmo de Otimização - PNL } & 117\end{array}$

$\begin{array}{lr}\text { B Dados das Usinas Hidroelétricas } & 119\end{array}$

$\begin{array}{lr}\text { C Estudos Complementares } & 121\end{array}$ 
Referências Bibliográficas 132 


\section{Lista de Figuras}

2.1 Sistema hidrotérmico. . . . . . . . . . . . . . . 8

2.2 Cronograma de decisão para sistemas hidrotérmicos. . . . . . . . . . . 9

2.3 Perfil típico de uma usina hidroelétrica. . . . . . . . . . . . . . . . 14

2.4 Custo de operação do sistema não hidráulico $\ldots \ldots \ldots$. . . . . . . . 17

2.5 Fluxograma do Algoritmo desenvolvido utilizando 2 estágios. . . . . . . 25

2.6 Mutação direcionada. . . . . . . . . . . . . . . . . . 26

2.7 Elitismo parcial. . . . . . . . . . . . . . . . . . 27

3.1 Exemplo de mutação. . . . . . . . . . . . . . . . . . . 37

3.2 Exemplo de cruzamento de um ponto. . . . . . . . . . . . . 38

3.3 Exemplo de cruzamento de dois ponto. . . . . . . . . . . . . . 38

3.4 Exemplo de cruzamento uniforme. . . . . . . . . . . . . . . . 39

3.5 Exemplo de elitismo. . . . . . . . . . . . . . . . . . 40

4.1 Algoritmo proposto . . . . . . . . . . . . . . . . 43

4.2 População. . . . . . . . . . . . . . . . . . . . . . . 44

4.3 Cruzamento uniforme proposto. . . . . . . . . . . . . 51

4.4 Cruzamento médio proposto. . . . . . . . . . . . 55

4.5 Mutação proposta. . . . . . . . . . . . . . . 56

4.6 Novo indivíduo após mutação proposta . . . . . . . . . . . . . 58

4.7 Mutação local proposta. . . . . . . . . . . . . . . . . . . 59 
4.8 Mutação gradiente. . . . . . . . . . . . . . . . . . . . . . . . 62

4.9 Parte do Sistema Sudeste Brasileiro utilizado no Estudo . . . . . . . . . 62

4.10 Estudo - Trajetória ótima de volume para as 7 usinas (PNL) . . . . . . 64

4.11 Estudo - Trajetória ótima de volume para as 7 usinas (PNL+AGs) . . . 65

4.12 Estudo - Complementação térmica para uma usina isolada . . . . . . . . 66

4.13 Estudo - Complementação térmica para uma usina isolada escala ampliada 66

4.14 Estudo - Complementação térmica para três usinas em cascata . . . . . 67

4.15 Estudo - Complementação térmica para três usinas em cascata escala ampliada . . . . . . . . . . . . . . . 68

4.16 Estudo - Complementação térmica para sete usinas em cascata . . . . 68

4.17 Estudo - Complementação térmica para sete usinas em cascata escala ampliada . . . . . . . . . . . . . . . . . . . 69

5.1 Custo médio na análise dos operadores de cruzamentos propostos. . . . 82

6.1 Parte do Sistema Sudeste Brasileiro . . . . . . . . . . . . . . . . . 85

6.2 Estudo I - Trajetória ótima de volume no período de 1947 a 1949 . . . . 87

6.3 Estudo I - Trajetória ótima de volume no período de 1947 a 1949 . . . . 88

6.4 Estudo I - Complementação térmica para sete usinas em cascata (1947$1949) \ldots \ldots \ldots \ldots \ldots \ldots$

6.5 Estudo II - Trajetória ótima de volume no período de 1953 a 1955 . . . 90

6.6 Estudo II - Trajetória ótima de volume no período de 1953 a 1955 . . . 90

6.7 Estudo II - Complementação térmica para sete usinas em cascata (1953$1955) \ldots \ldots \ldots \ldots \ldots \ldots$. . . . . . . . . . . . . . . . . . . . . . . .

6.8 Estudo III - Complementação térmica para sete usinas em cascata (1981-

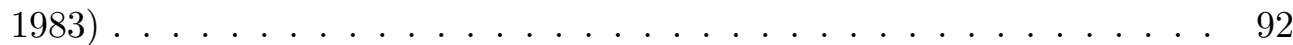

6.9 Estudo IV - Trajetória ótima de volume da cascata do rio Paranaiba . . 93

6.10 Estudo IV - Trajetória ótima de volume da cascata do rio Araguari . . . 94 
6.11 Estudo IV - Trajetória ótima de volume da cascata do rio Grande . . . 94

6.12 Estudo IV - Trajetória ótima de volume da cascata do rio Pardo . . . . 95

6.13 Estudo IV - Trajetória ótima de volume da cascata do rio Tietê . . . . . 95

6.14 Estudo IV - Trajetória ótima de volume da cascata do rio Paranapanema 96

6.15 Estudo IV - Trajetória ótima de volume da cascata do rio Paraná . . . . 96

6.16 Estudo IV - Geração Hidráulica e Complementação Térmica das usinas a reservatório do Sistema Sudeste . . . . . . . . . . . . . . . . . 97

6.17 Estudo IV - Trajetória ótima de volume de algumas usinas do Sistema Sudeste com afluência igual a $80 \%$ da MLT . . . . . . . . . . . . . 98

6.18 Estudo IV - Geração Hidráulica e Complementação Térmica das usinas a reservatório do Sistema Sudeste com afluência igual a 80\% da MLT . . 98

6.19 Estudo IV - Trajetória ótima de volume no período de 1947 a 1949 . . 99

6.20 Estudo IV - Geração Hidráulica e Complementação Térmica das usinas a reservatório do Sistema Sudeste no período de 1947 a 1949 . . . . . . 99

6.21 Estudo IV - Trajetória ótima de volume no período de 1953 a 1955 . . 100

6.22 Estudo IV - Geração Hidráulica e Complementação Térmica das usinas a reservatório do Sistema Sudeste no período de 1953 a 1955 . . . . . . 100

6.23 Estudo V - Trajetória ótima de volume da cascata do rio Paranaíba . 102

6.24 Estudo V - Trajetória ótima de volume da cascata do rio Araguari . . . 102

6.25 Estudo V - Trajetória ótima de volume da cascata do rio Grande . . . . 103

6.26 Estudo V - Trajetória ótima de volume da cascata do rio Pardo . . . . . 103

6.27 Estudo V - Trajetória ótima de volume da cascata do rio Tietê . . . . . 104

6.28 Estudo V - Trajetória ótima de volume da cascata do rio Paranapanema 104

6.29 Estudo V - Trajetória ótima de volume da cascata do rio Paraná . . . . 105

6.30 Estudo V - Geração Hidráulica e Complementação Térmica das usinas do Sistema Sudeste . . . . . . . . . . . . . . . . . . . . . . . . . . . 105

6.31 Estudo V - Trajetória ótima de volume da cascata do rio Paranaiba . 106 
6.32 Estudo V - Trajetória ótima de volume da cascata do rio Araguari . . . 106

6.33 Estudo V - Trajetória ótima de volume da cascata do rio Grande . . . . 107

6.34 Estudo V - Trajetória ótima de volume da cascata do rio Pardo . . . . . 107

6.35 Estudo V - Trajetória ótima de volume da cascata do rio Tietê . . . . 108

6.36 Estudo V - Trajetória ótima de volume da cascata do rio Paranapanema 108

6.37 Estudo V - Trajetória ótima de volume da cascata do rio Paraná ... 109

6.38 Estudo V - Geração Hidráulica e Complementação Térmica das usinas do Sistema Sudeste . . . . . . . . . . . . . . . . . . . . . . . 109

6.39 Estudo V - Trajetória ótima de volume da cascata do rio Paranaiba . . 110

6.40 Estudo V - Trajetória ótima de volume da cascata do rio Araguari . . . 111

6.41 Estudo V - Trajetória ótima de volume da cascata do rio Grande . . . . 111

6.42 Estudo V - Trajetória ótima de volume da cascata do rio Pardo . . . . . 112

6.43 Estudo V - Trajetória ótima de volume da cascata do rio Tietê . . . . . 112

6.44 Estudo V - Trajetória ótima de volume da cascata do rio Paranapanema 113

6.45 Estudo V - Trajetória ótima de volume da cascata do rio Paraná . . . . 113

6.46 Estudo V - Geração Hidráulica e Complementação Térmica das usinas do Sistema Sudeste . . . . . . . . . . . . . . . . . . . . . . . . . . . . . . 114

C.1 Cascata utilizada no Estudo Complementar I . . . . . . . . . . . . . 121

C.2 Afluência natural utilizada no Estudo Complementar I (MLT) . . . . . . 122

C.3 Estudo Complementar I - Trajetória ótima de volume . . . . . . . . . . 122

C.4 Trajetórias de Vazão afluentes, vazão turbinada máxima e defluência das usinas hidroelétricas de Emborcação, Itumbiara, Cachoeira Dourada e São Simão. . . . . . . . . . . . . . . . . . . . . . . . . . . . . 123

C.5 Estudo Complementar I - Geração hidráulica. . . . . . . . . . . . . . . . 124

C.6 Estudo Complementar I - Complementação térmica. . . . . . . . . . . . 124

C.7 Estudo Complementar II - Cascata do Rio Grande utilizada no estudo. . 125

C.8 Estudo Complementar II - Trajetória de volume. . . . . . . . . . . . . 125 
C.9 Estudo Complementar II - Vazão afluente, vazão turbinada máxima e defluência das usinas hidroelétricas de Água Vermelha, Estreito e Furnas. 126

C.10 Estudo Complementar II - Geração hidráulica. . . . . . . . . . . . . . . 127

C.11 Estudo Complementar II - Complementação Térmica. . . . . . . . . . . 127

C.12 Estudo Complementar II - Cascata do Rio Grande utilizada no estudo. . 128

C.13 Estudo Complementar III - Trajetória de volume. . . . . . . . . . . . . . 128

C.14 Estudo Complementar III - Vazão afluente, vazão turbinada máxima e defluência das usinas hidroelétricas de Camargo, itutinga, Furnas, Peixoto, Estreito e Jaguará. . . . . . . . . . . . . . . . . . . . . . . . . 129

C.15 Estudo Complementar III - Vazão afluente, vazão turbinada máxima e defluência das usinas hidroelétricas de Volta Grande, Porto Colômbia, Marimbondo e Água Vermelha. . . . . . . . . . . . . . . . . . . . . . . . 130

C.16 Estudo Complementar III - Geração hidráulica. . . . . . . . . . . . . . . 131

C.17 Estudo Complementar III - Complementação Térmica. . . . . . . . . . . 131 


\section{Lista de Tabelas}

1.1 Capacidade de Geração do Brasil (Set/2003). . . . . . . . . . . . . . 2

2.1 Capacidade hidráulica instalada em alguns países e no mundo (Jan/2001) 13

3.1 Terminologia Biológica x Terminologia Computacional x Terminologia do Planejamento da Operação. . . . . . . . . . . . . . . . . . . . . . 34

4.1 Dados da Usina hidroelétrica de Emborcação . . . . . . . . . . . . . . . 42

4.2 Dados de demanda e afluência para resolução do problema proposto . 42

4.3 Dados utilizados na seleção da população. . . . . . . . . . . . . . . . . 48

4.4 Tipos de taxas adotadas na seleção, cruzamento ou mutação. . . . . . . 50

4.5 Estudo - Custo de Operação . . . . . . . . . . . . . . . . . . . . . . . 64

5.1 Conjunto de testes. . . . . . . . . . . . . . . . . . 71

5.2 Configuração da população utilizada nos testes para analisar o tamanho da população e a solução inicial . . . . . . . . . . . . . . . . 73

5.3 Definição do tamanho da população e solução inicial. . . . . . . . . . . . 79

5.4 Configurações das populações adotadas nos testes de ponderação dos operadores genéticos. . . . . . . . . . . . . . . . . . 83

B.1 Dados das usinas hidroelétricas utilizados nos estudos I, II, III, IV e V • 119 


\section{Lista de Abreviaturas e Siglas}

- PCH - Pequenas Centrais Hidroelétricas;

- UHE - Usinas Hidroelétricas;

- CGH - Central Geradora Hidroelétrica;

- UTE - Usinas Termoelétricas;

- EOL - Central Geradora Eolielétrica;

- UTN - Usina Termonuclear;

- ANEEL - Agência Nacional de Energia Elétrica;

- BIG - Banco de Informação de Geração;

- MW - Megawatt $=10^{6}$ watts (Potência Ativa)

- POSHP - Planejamento da Operação de Sistemas Hidrotérmicos de Potência;

- IA - Inteligência Artificial;

- AGs - Algoritmos Genéticos;

- GH - Geração Hidroelétrica;

- GT - Geração Térmica;

- I - Importação de energia;

- PO - Planejamento da Operação;

- PDE - Programação Dinâmica Estocástica;

- ONS - Operador Nacional do Sistema; 
- TVA - Teneessee Valey Authority;

- PDED - Programação Dinâmica Estocástica Dual;

- TS - Tabu Search;

- SA - Simulated Annealing;

- MLT - Média de Longo Termo;

- PNL - Programação Não-Linear; 


\section{Lista de Símbolos}

- $g$ - potência gerada;

- $a, b, c$ - parâmetros característicos da usina termoelétrica;

- $H_{i j}$ - elemento da matriz Hessiana, dada pela derivada segunda em relação à variável x, da linha i, e y, da coluna j (defluência ou volume).

- F - função objetivo do problema;

- $x(t)$ - volume do reservatório no instante t;

- $x_{\text {mím }}$ - volume mínimo do reservatório;

- $x_{\text {máx }}$ - volume máximo do reservatório;

- $x_{u ́ t i l}$ - volume útil do reservatório;

- $q(t)$ - vazão turbinada pela usina no instante t;

- $v(t)$ - vazão vertida pela usina no instante t;

- $u(t)$ - defluência total da usina no instante t;

- $h_{m o n(x)}$ - nível d'água a montante do reservatório, função do volume de água acumulado;

- $h_{j u s(x)}$ - nível d'água a jusante do reservatório, função da defluência total da usina;

- $h(x, u)$ - altura de queda bruta da usina, definida como a diferença entre as alturas montante e a jusante do reservatório;

- $N$ - número de usina hidroelétricas; 
- $\phi_{i}($.$) - função de geração hidroelétrica da usina i;$

- $x_{i}($.$) - volume do reservatório i no intervalo t;$

- $q_{i}($.$) - vazão turbinada pela usina i no intervalo t;$

- $z_{i}($.$) - vazão vertida da usina i no instante t;$

- $u_{i}($.$) - vazão defluída da usina i no instante t;$

- $K_{i}$ - constante que engloba aceleração da gravidade, densidade da água, rendimento turbina-gerador e fatores de conversão de unidade;

- $h_{1 i}$ - altura de montante, em relação ao nível do mar, função do volume do reservatório;

- $h_{2 i}$ - altura de jusante, em relação ao nível do mar, função da vazão defluída total;

- $y_{i}(t)$ - afluência ao reservatório i no instante t;

- $\Omega_{i}$ - conjunto de todas as usinas imediatamente a montante da usina i; 


\section{Resumo}

Leite P. T. Aplicação de Técnicas de Inteligência Artificial no Planejamento da Operação de Sistemas Hidrotérmicos de Potência. São Carlos, 2003, Tese (Doutorado) - Escola de Engenharia de São Carlos, Universidade de São Paulo.

Neste trabalho foi investigado um novo modelo baseado em Inteligência Artificial como ferramenta para a resolução do Problema do Planejamento da Operação de Sistemas Hidrotérmicos de Potência.

Esta abordagem, que utiliza os princípios da evolução genética, tem se destacado com alta eficiência na solução de problemas de otimização. Para atender a todas as características do problema foram feitas algumas adaptações dos operadores genéticos tradicionais de recombinação e mutação, sendo o problema codificado usando uma cadeia de números reais, e não binários como normalmente é apresentado na literatura. Para isto, foram realizados vários testes visando moldar a técnica ao problema em questão, levando em conta suas características específicas.

O algoritmo proposto também foi aplicado em vários testes com usinas pertencentes ao Sistema Hidroelétrico Brasileiro e mostrou o bom desempenho desta abordagem em determinar uma operação ótima, garantindo, da melhor forma possível, o atendimento da demanda por um custo mínimo e com confiabilidade. As aplicações incluíram sistemas complexos, de grande porte, com até 35 usinas hidroelétricas, onde foram obtidos resultados satisfatórios.

Palavras-Chave: Algoritmos Genéticos, Inteligência Artificial, Sistemas Híbridos Genéticos, Sistemas Hidrotérmicos, Planejamento da Operação e Otimização. 


\section{Abstract}

Leite P. T. Artificial Intelligence Applied to Planning of the Hydrothermal Systems. São Carlos, 2003 Thesis (Doctor) - Escola de Engenharia de São Carlos, Universidade de São Paulo.

The present thesis investigates a new model based on Artificial Inteligence as a tool to solve the problem of the Operational Planning of Hydrothermal Systems.

This approach, which uses the principle of Genetic Evolution, has been very successful and efficient in the solution of optimization problems. To represent all the characteristics of the problem some adaptations of the traditional genetic operators of recombination and mutation were made. The problem used a string of real numbers instead of binary as usually presented in the literature. Thus, several tests were performed in order to adapt the technique to the problem, taking into account its specific characteristics.

The proposed algorithm has been applied in several tests in real Hydrothermal Systems, with plants belonging to the Brazilian Southeast System. The results achieved so far have indicated that the proposed approach can be an effective alternative or a complementary technique for the Planning of Hydrothermal System, as it determines an operation strategy for each power plant and minimizes the expected value of the operative cost along the planning horizon. The applications include large systems, with up to 35 hydroeletric plants, where good results were obtained.

Key-Words: Genetic Algorithms, Artificial Intelligence, Hybrid Genetic Algorithms, Hydrothermal Systems, Operation Planning and Optimization. 


\section{Capítulo 1}

\section{Introdução}

A energia elétrica tornou-se indispensável para a sobrevivência do ser humano. Sendo assim, o seu consumo vem aumentando em todo o mundo, principalmente em países em ascensão como o Brasil, estando diretamente ligado ao nível sócio-econômico da população.

A geração de energia elétrica pode ser obtida através de diversas fontes energéticas. No Brasil destacam-se: o uso de energia potencial da água, geração hidroelétrica (PCH - Pequenas Centrais Hidroelétricas, UHE - Usinas Hidroelétricas e CGH - Central Geradora Hidroelétrica), energia térmica (UTE - Usinas Termoelétricas), que utiliza combustíveis fósseis como petróleo e carvão mineral, combustíveis não fósseis como madeira e bagaço de cana, e ainda, em pequena escala, as que utilizam o vento (EOL - Central Geradora Eolielétrica) e as de combustível nuclear como urânio enriquecido (UTN - Usina Termonuclear). Na Tabela 1.1, são apresentadas as contribuições de cada fonte de energia, a potência instalada e sua participação percentual no Sistema Brasileiro. Esses dados são referentes a setembro de 2003, segundo informações da Agência Nacional de Energia Elétrica (ANEEL), obtidos do Banco de Informações de Geração $(\mathrm{BIG})^{1}$, lembrando que o Brasil é um dos poucos países com potencial hidráulico a ser ainda explorado.

Com o crescimento acelerado do país, existe a necessidade de um Planejamento da Operação cada vez mais avançado, que englobe as fontes de geração de energia elétrica,

\footnotetext{
${ }^{1}$ Os valores de porcentagem são referentes à Potência Fiscalizada, ou seja, é igual à considerada a partir da operação comercial da primeira unidade geradora.
} 
com o objetivo de garantir, da melhor forma possível, o atendimento da demanda. Este é um grande desafio para os gerenciadores do Setor Elétrico Brasileiro, agravado inclusive pela recente crise de abastecimento de energia, para a qual contribuiu decisivamente a falta de investimentos que acompanhassem a evolução das necessidades.

Além disso, a decisão política de reestruturar o Setor, com privatizações e desregulamentações, acompanhando algumas tendências internacionais, modificou bastante o ambiente de atuação das empresas de energia elétrica, trazendo novos e importantes desafios para o Planejamento da Operação. Uma das medidas para enfrentar estes desafios seria o desenvolvimento de técnicas de otimização e simulação mais sofisticadas e seguras, que possam auxiliar o planejamento da operação.

Este trabalho propõe uma técnica de otimização para a operação de sistemas hidrotérmicos, voltada para o Sistema Brasileiro, o qual possui características específicas que o diferencia dos demais sistemas no mundo, o que tem motivado o estudo e desenvolvimento de abordagens mais apropriadas.

Tabela 1.1: Capacidade de Geração do Brasil (Set/2003).

\begin{tabular}{|c|r|r|r|}
\hline Tipo & Quantidade & Potência (KW) & $\%$ \\
\hline CGH & 149 & 82.328 & 0.10 \\
\hline EOL & 9 & 22.025 & 0.03 \\
\hline PCH & 230 & 1.001 .269 & 1.18 \\
\hline UHE & 139 & 65.856 .132 & 77.62 \\
\hline UTE & 735 & 15.872 .473 & 18.71 \\
\hline UTN & 2 & 2.007 .000 & 2.44 \\
\hline Total & 1.265 & 84.841 .247 & 100 \\
\hline
\end{tabular}

A área dos sistemas de potência que trata justamente das necessidades energéticas por parte das usinas, de forma coordenada, é o chamado Planejamento da Operação de Sistemas Hidrotérmicos de Potência (POSHP). O objetivo do POSHP é encontrar uma política operativa que forneça energia elétrica ao sistema, em um determinado período, com confiabilidade e por um custo mínimo. Isto equivale a determinar um cronograma ótimo de geração para cada usina, a cada intervalo, de modo que o sistema atenda a demanda de forma confiável, procurando evitar o racionamento em ano de seca severa, e minimize o custo esperado da operação durante o período de planejamento, definindo uma estratégia adequada de complementação térmica. 
O POSHP vem sendo formulado através de modelos de otimização e simulação, onde têm-se problemas não-lineares bastante complexos. Vários algoritmos de otimização aplicados a este problema foram desenvolvidos, mas apresentam deficiências como dificuldade de convergência, simplificação da formulação original do problema, ou dificuldade devido à complexidade da função objetivo [ROSENTHAL (1980)]. Por outro lado, técnicas de Inteligência Artificial (IA) têm sido aplicadas com sucesso, em diversas áreas de Sistemas Elétricos de Potência, entre elas proteção, controle e supervisão, alarme, segurança, previsões, planejamento, etc.,[WARWICK et al. (1997), JONGEPIER (1996), MADAN \& BOLLINGER (1997) e ALANDER (2001)].

Dentre os vários métodos de Inteligência Artificial existentes na literatura, os que têm se destacado com alta eficiência na solução dos problemas de otimização são aqueles baseados em Algoritmos Genéticos (AGs), tornando esta técnica muito interessante como ferramenta de busca e otimização para a solução dos mais diferentes tipos de problemas, o que motivou a aplicação de AGs ao problema apontado. O desenvolvimento dessa pesquisa iniciou-se durante o mestrado da aluna, onde a investigação da aplicação de AGs ao POSHP foi iniciada [LEITE (1999)].

Atestada esta viabilidade, elaborou-se o projeto de Doutorado, que teve como objetivo a melhor codificação do problema bem como a aplicação de AGs em sistemas mais complexos. Um algoritmo mais elaborado foi desenvolvido com esta técnica e sua aplicação foi feita em situações reais de usinas do Sistema Brasileiro. Vale lembrar que a elaboração deste texto foi fortemente baseada nas publicações realizadas durante o desenvolvimento do doutorado, tomando como ponto de partida a dissertação de mestrado.

\subsection{Contribuições desta Tese}

Em todo o mundo tem-se procurado aperfeiçoar a solução do Problema do Planejamento da Operação de Sistemas Hidrotérmicos de Potência. Desta forma, vários modelos foram desenvolvidos e algumas técnicas de otimização investigadas. Destas, destacam-se a Programação Dinâmica Estocástica, a Programação Dinâmica Estocástica Dual, vários métodos de Programação Não Linear e os métodos de Linearização. As características de cada abordagem serão descritas na seção 2.5 . 
O problema do POSHP, como já apontado, é bastante complexo, principalmente no caso brasileiro, onde existe um grande número de usinas hidroelétricas hidraulicamente interligadas. Pode-se dizer que o problema do planejamento ainda não está superado. As diversas abordagens já desenvolvidas não apresentaram desempenho plenamente satisfatório para todos os aspectos do problema. Desta forma, é natural, e até necessária, a investigação de novos modelos com técnicas de otimização mais sofisticadas. Portanto, neste trabalho procurou-se representar todas as características de operação das usinas de forma individualizada e assim simular situações reais do sistema, evitando simplificações que possam apontar valores fictícios de operação ocasionando erros do planejamento da operação e, conseqüentemente, custos mais elevados e até déficit no abastecimento de energia.

Com a finalidade de encontrar um método eficaz, ou auxiliar, na solução do problema, este trabalho investigou o estudo da aplicação de técnica de IA com a intenção de desenvolver um modelo que possibilite uma política operativa que forneça energia elétrica ao sistema em um determinado período com confiabilidade e custo mínimo.

Mais especificamente, uma nova técnica que utiliza os princípios da evolução genética, os Algoritmos Genéticos, é proposta para solucionar o problema apontado. Esta abordagem permite uma representação individualizada das usinas independente do tamanho do sistema. A mesma é relativamente simples de ser aplicada, não apresenta a necessidade de alteração da formulação original do problema, garantindo assim as características particulares, e contornando as dificuldades apresentadas pelas técnicas clássicas de resolução de programação não linear, oriundas da complexidade do problema de planejamento da operação.

\subsection{Organização Geral deste Documento}

O presente trabalho está organizado da seguinte forma:

O Capítulo 2 contém a introdução do POSHP, com suas principais características, componentes de uma usina hidroelétrica, a formulação matemática e, finalizando, a revisão bibliográfica.

Um resumo sobre Algoritmos Genéticos, histórico e apresentação dos operadores genéticos tradicionalmente utilizados serão apresentados no Capítulo 3. 
O algoritmo proposto e uma aplicação em sistemas hidroélétricos, para confirmar na prática a viabilidade da técnica, serão apresentados no Capítulo 4.

No Capitulo 5, é feito um estudo dos parâmetros utilizados na configuração do algoritmo proposto.

Aplicações mais complexas em sistema hidroelétricos e os seus resultados serão apresentados no Capítulo 6, bem como a comparação entre a técnica de otimização baseada em Programação Não-linear (PNL), tradicionalmente utilizada, e a técnica proposta por este trabalho.

No Capítulo 7, algumas conclusões e comentários são apresentados e, seguindo-se a estes, as referências bibliográficas e os apêndices.

\subsection{Artigos Publicados}

A pesquisa gerou as publicações relacionadas a seguir, sendo parte essencial deste texto baseada nas mesmas.

\section{Capitulo de livro:}

1. Leite, P. T., Carneiro, A. A. F. M e Carvalho, A. P. L. F. (2003). In: REZENDE, S. O. (org) Sistemas Inteligentes: Fundamentos e Aplicações. Barueri, SP: Manole, p. 373-375.

\section{Periódico internacional:}

2. Leite, P. T., Carneiro, A. A. F. M e Carvalho, A. P. L. F. (2002). Energetic Operation Planning Using Genetic Algorithms, IEEE - Transaction on Power Systems, v. 17, n. 1, p. 173-179.

\section{Congresso nacional:}

3. Leite, P. T., Carneiro, A. A. F. M e Carvalho, A. P. L. F. (2003). Aplicação de Inteligência Artificial no Planejamento da Operação de Sistemas Hidrotérmicos 
de Potência, (CD Rom), XVII SNPTEE - Seminário Nacional de Produção e Transmissão de Energia Elétrica, 19-24 de outubro, Uberlândia.

4. Leite, P. T., Carneiro, A. A. F. M and Carvalho, A. P. L. F. (2002). Genetic Operators Setting for the Operation Planning of Hydrothermal Systems, V Brazilian Symposium on Neural Networks, 14-17 November, Recife, Brasil.

5. Leite, P. T., Carneiro, A. A. F. M e Carvalho, A. P. L. F. (2002). Aplicação de Algoritmo Genéticos na Determinação da Operação ótima de Sistemas Hidrotérmicos de Potência, (CD Rom), XIV Congresso Brasileiro de Automática, 02-05 de setembro, Natal.

6. Leite, P. T., Carneiro, A. A. F. M and Carvalho, A. P. L. F. (2001) Aplicação de Algoritmos Genéticos Híbridos em sistemas Hidrotérmicos de Potência, (CD Rom) ENIA 2001 - Encontro Nacional de Inteligência Artificial, 30-03 de Agosto, Fortaleza, Brasil.

7. Leite, P. T., Carneiro, A. A. F. M and Carvalho, A. P. L. F. (2000). Scheduling of Hydroeletric Power Systems Using Genetic Algorithms, (CD Rom) VII SEPOPE - Symposium of Specialists in Eletric Operation and Expansion Planning, 21-29 May, Curitiba, Brasil.

\section{Congresso internacional}

8. Leite, P. T., Carneiro, A. A. F. M and Carvalho, A. P. L. F. (1999). Application of Genetic Algorithms to Define the Optimal operation of Hydroeletric Power Systems, IASTED - Artificial Intelligence and Soft Computing, 12 August, Honolulu, Hawai - USA, p. 591-595.

\section{Trabalhos submetidos}

9. Leite, P. T., Carneiro, A. A. F. M and Carvalho, A. P. L. F. (2003), Aplicação de Algoritmo Genéticos na Determinação da Operação ótima de Sistemas Hidrotérmicos de Potência, Revista Controle e Automação, Sociedade Brasileira de Automática - SBA (artigo convidado para publicação - em revisão). 


\section{Trabalho que será publicado}

10. Leite, P. T., Carneiro, A. A. F. M e Carvalho, A. P. L. F. (2003). In: A. G. Evsukoff e N. F. F. Ebecken. Mineração de Dados em Recursos Hídricos. R. C. V. Silva (editor) Métodos Numéricos em Recursos Hídricos vol. 6, Capítulo 1. Fundação COPPETEC/ABRH. 2003 (a referência deve sair em Novembro/2003). 


\section{Capítulo 2}

\section{O Planejamento da Operação}

\subsection{Introdução}

Os sistemas energéticos de potência podem ser, simplificadamente divididos em: geração, transmissão e consumo. A geração em grande escala pode ser obtida de forma hidroelétrica, quando resulta do aproveitamento da energia potencial da água, e térmica, através da queima de combustíveis diversos como carvão, óleo, gás ou fissão do urânio e, eventualmente, importação de energia elétrica de sistemas vizinhos. Toda a energia elétrica disponível é enviada através das linhas de transmissão para o atendimento da demanda, conforme ilustrado na Figura 2.1.

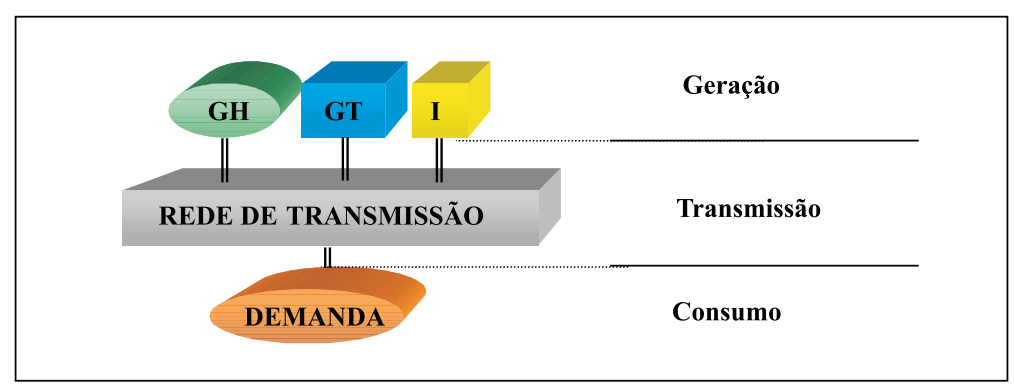

Figura 2.1: Sistema hidrotérmico.

Onde:

GH - Geração Hidroelétrica;

GT - Geração Térmica;

I - Importação de energia. 
Em sistemas com uma porcentagem substancial de geração hidroelétrica, como no caso do Brasil, aproximadamente 79\% [ANEEL (2003)], pode-se utilizar a energia armazenada nos reservatórios do sistema para atender a demanda, substituindo assim a geração dispendiosa das unidades térmicas.

Entretanto, o volume de água afluente aos reservatórios é desconhecido, pois depende basicamente das afluências que irão ocorrer no futuro. Além disso, a disponibilidade de energia hidroelétrica é limitada pela capacidade de armazenamento nos reservatórios. Isto introduz uma relação entre uma decisão de operação em uma determinada etapa e as conseqüências futuras desta decisão. Por exemplo, se a decisão for utilizar energia hidroelétrica para atender o mercado e no futuro ocorrer uma seca, poderá ser necessário utilizar geração térmica, de custo elevado, ou interromper o fornecimento de energia. Por outro lado, se a opção for o uso mais intensivo de geração térmica, conservando elevados os níveis dos reservatórios, e ocorrerem vazões altas no futuro, poderá haver vertimento no sistema, representando um desperdício de energia e, em conseqüência, um aumento desnecessário do custo de operação [SILVA (2001) e MAE (2002)], conforme ilustrado na Figura 2.2

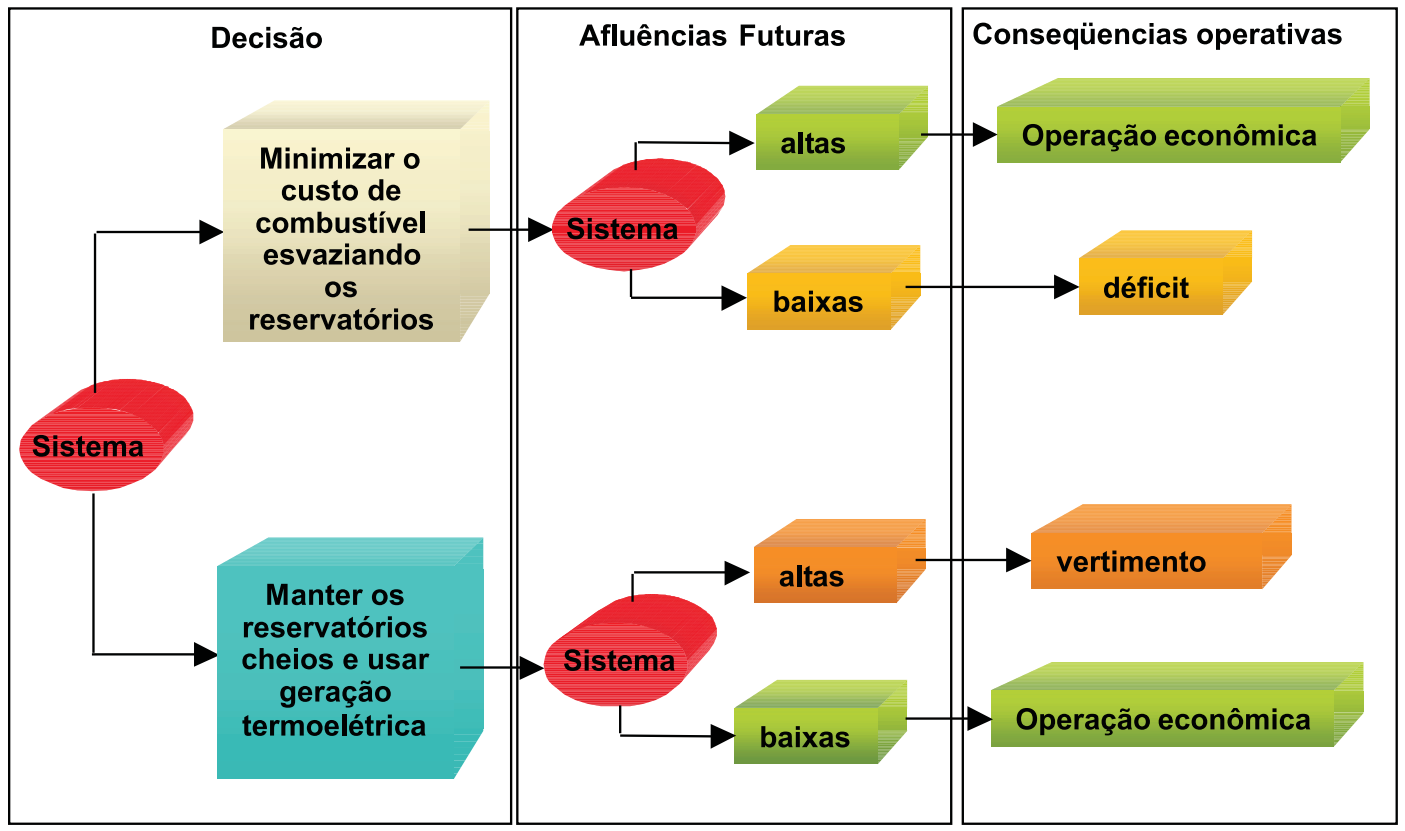

Figura 2.2: Cronograma de decisão para sistemas hidrotérmicos. 
A decisão ótima deve equilibrar o compromisso entre o benefício presente do uso da água para a geração hidroelétrica e o benefício futuro esperado, advindo do seu armazenamento, tudo medido em termos de economia de combustível, caracterizando um problema dinâmico.

O custo de operação de um sistema hidrotérmico é dado pela complementação térmica do sistema, ou seja, pelo custo do suprimento da parcela da demanda que não foi atendida pela geração hidroelétrica, mas sim pela geração térmica. Logo, a não linearidade da função objetivo deste problema deve-se, em primeiro lugar, à não linearidade do custo de geração térmica. Em segundo lugar, resulta da própria não linearidade da função de geração hidroelétrica, conforme pode ser visto com maiores detalhes na formulação matemática na seção 2.5 .

A função objetivo é também não convexa em toda sua região de abrangência, o que pode ser verificado através dos auto valores da matriz Hessiana, os quais apresentam valores positivos e negativos em algumas regiões [CARNEIRO \& MONTANHA (1997)].

Quando as usinas hidroelétricas estão situadas em uma mesma bacia hidrográfica, elas apresentam, de forma mais evidente, um acoplamento operativo entre si, formando um problema não-separável.

O parque hidroelétrico constitui-se em um sistema interconectado de geração, ao contrário do parque termelétrico, cujas unidade são independentes entre si. Isto pode ser melhor explicado analisando a matriz Hessiana da função de custo de operação do sistema, ou função objetivo do problema do Planejamento Energético da Operação, onde observam-se elementos fora da diagonal principal não nulos, o que representa a interconexão entre as variáveis de usinas diferentes [CARNEIRO \& MONTANHA (1997) e KADOWAKI (1995)]. Isto se traduz em uma função objetivo espacialmente não-separável, ou seja, não se pode isolar as variáveis de cada usina separadamente.

Este é também um problema estocástico em sua conceituação mais ampla, devido à aleatoriedade das vazões, além de ser de grande porte, devido ao grande número de usinas e intervalos envolvidos.

Dadas as características de geração das usinas hidroelétricas, o Planejamento da Operação de Sistemas Hidrotérmicos pode ser classificado como um problema de otimização dinâmico, de grande porte, com função objetivo não-linear, não-separável e não convexa 
[PEREIRA (1985), SOARES \& CARNEIRO (1991) e CARNEIRO \& BOND (1990)].

Como já afirmado, o objetivo do POSHP é determinar uma estratégia de geração para cada usina, que minimize o valor esperado dos custos operativos no período de planejamento e atenda a demanda de forma confiável. Incluem-se nestes custos os gastos com os combustíveis das usinas termoelétricas, eventuais compras de energia de sistemas vizinhos e os custos de eventuais não atendimentos à demanda [FORTUNATO et al. (1985)]. Em sistemas com grande participação hidroelétrica, o objetivo econômico do planejamento da operação é substituir, na medida do possível e de forma racional, a geração de origem termoelétrica, de custo elevado, por geração de origem hidroelétrica, de custo praticamente nulo [CARNEIRO \& BOND (1990) e FORTUNATO et al. (1985)].

Devido à sua própria dificuldade e à diversidade de objetivos e de características em que estão imersos os vários aspectos do problema, o Planejamento da Operação (PO) é dividido em diferentes horizontes de tempo. No Sistema Brasileiro, o planejamento da operação é dividido em horizontes de médio ${ }^{1}$, curto $^{2}$ e curtíssimo ${ }^{3}$ prazos, onde são abordados os aspectos energéticos e elétricos da operação [PEREIRA (1985), CARNEIRO \& BOND (1990), MACIEIRA et al. (2003) e SOARES (1987)].

No médio prazo é determinada a política ótima de operação do sistema hidrotérmico brasileiro, considerando a capacidade de regularização pluri-anual do sistema, a aleatoriedade das afluências através de um grande número de cenários hidrológicos. O horizonte de decisão é tipicamente de 5 anos e o período de planejamento é discretizado em intervalos mensais. Neste horizonte costuma-se adotar programação dinâmica estocástica dual (PDED) para o sistema brasileiro.

Já no planejamento de curto prazo, adota-se um período de alguns meses a dois anos com discretização mensal ou semanal, em que se atribuem as metas de geração individual a cada usina hidroelétrica e térmica, a partir da política ótima de operação calculada na etapa anterior, considerando-se diversas restrições de geração e também algumas restrições elétricas. Neste nível a incerteza das afluências e considerada menor.

\footnotetext{
${ }^{1} \mathrm{O}$ planejamento de médio prazo, segundo a nova nomenclatura do Operador Nacional do Sistema (ONS), se refere ao antigo planejamento de longo prazo da operação eletroenergética. O termo longo prazo é usado atualmente para o planejamento da expansão de sistemas elétricos.

${ }^{2} \mathrm{O}$ planejamento de curto prazo se refere ao antigo planejamento de médio prazo.

${ }^{3} \mathrm{O}$ planejamento de curtíssimo prazo ou programação da operação se refere ao antigo planejamento de curto prazo.
} 
Pode-se adotar programação não-linear, através de abordagem determinística.

Em sistemas hidrotérmicos de potência onde há uma grande participação hidráulica, é fundamental determinar o comportamento ótimo dos reservatórios, definindo a melhor maneira de operação. Para que o comportamento de cada reservatório possa ser melhor determinado, é importante que seja adotada uma representação individualizada para as usinas, o que faz com que o número de variáveis do sistema seja geralmente grande. Assim, para viabilizar a otimização com representação individualizada das usinas, uma das opções é tratar o problema de forma determinística [RODRIGUES et al. (2003)].

No planejamento de curtíssimo prazo, o horizonte é de algumas horas a uma semana, e o objetivo é a desagregação da meta de geração semanal ou mensal previamente fornecida, considerando todos os aspectos energéticos, hidráulicos e elétricos não levados em conta nas etapas de planejamento com horizontes mais amplos [SOARES (1987)]. Esse planejamento pode ser resolvido por algoritmos de fluxo de carga acoplados com modelos de simulação hidráulica [FORTUNATO et al. (1985)].

Os horizontes de médio e curto prazo são conhecidos pela designação de planejamento energético, já que tratam do aspecto energético da operação. Este trabalho está voltado preferencialmente para este planejamento energético, tendo sido desenvolvido com vistas para o horizonte de curto prazo.

\subsection{Características dos Sistemas Energéticos em Alguns Países}

O Brasil, a Noruega, a Suécia e o Canadá são grandes produtores de hidroeletricidade, porém as suas fontes energéticas são determinadas pelos recursos existentes e ainda conforme as características ambientais da região tais como relevo, clima, etc, sendo diferentes na maior parte dos países, alguns com sistemas de pequena ou grande participação hidroelétrica, outros quase que puramente térmicos [EIA (2001)]. Portanto, para cada tipo de sistema é empregada uma abordagem, apesar de se manter a filosofia básica quanto aos objetivos a serem atingidos. 
Na Tabela 2.1, é apresentada a capacidade hidráulica instalada em alguns países ${ }^{4}$.

Tabela 2.1: Capacidade hidráulica instalada em alguns países e no mundo (Jan/2001)

\begin{tabular}{|c|r|}
\hline País & Capacidade instalada $\left(10^{3} \mathbf{M W}\right)$ \\
\hline Brasil & 61,90 \\
\hline Canadá & 67,23 \\
\hline Noruega & 27,65 \\
\hline EUA & 98,88 \\
\hline Suécia & 16,36 \\
\hline Nova Zelândia & 5,19 \\
\hline Alemanha & 4,33 \\
\hline Mundo & $\mathbf{7 1 2 , 7 7}$ \\
\hline
\end{tabular}

O Brasil possui um sistema de geração predominantemente hidroelétrico, devido ao grande potencial hidráulico existente no país, onde se localizam grandes cascatas com usinas interligadas espalhadas em grande extensão territorial, sob regimes hidrológicos diversos.

O relevo brasileiro é suave, sem grandes montanhas, fazendo com que as usinas, em geral, tenham alturas de queda pequenas ou médias, levando, muitas vezes, a que o volume do reservatório da usina afete significativamente, sua produtividade. Também, as vazões afluentes às usinas sofrem, ao longo do tempo, relativamente grandes variações introduzindo incertezas quanto às operações futuras.

Adicionalmente, a privatização de usinas e o novo ambiente competitivo dificultam a determinação de uma operação que, pela sua própria essência, tem que ser cooperativa. Tudo isso leva a um cenário operativo bastante complexo onde o uso de métodos tradicionais utilizados em outros países, nem sempre traz bons resultados. Portanto, as características próprias do sistema brasileiro estimulam o desenvolvimento de métodos computacionais e critérios adequados às suas condições [PEREIRA et al. (1987)].

\footnotetext{
${ }^{4}$ Fonte: U.S. Department of Energy, Janeiro de 2001
} 


\subsection{Parâmetros de Uma Usina Hidroelétrica}

A Figura 2.3 é apresentada, para que se possa visualizar melhor as variáveis envolvidas no modelo matemático da usina, onde:

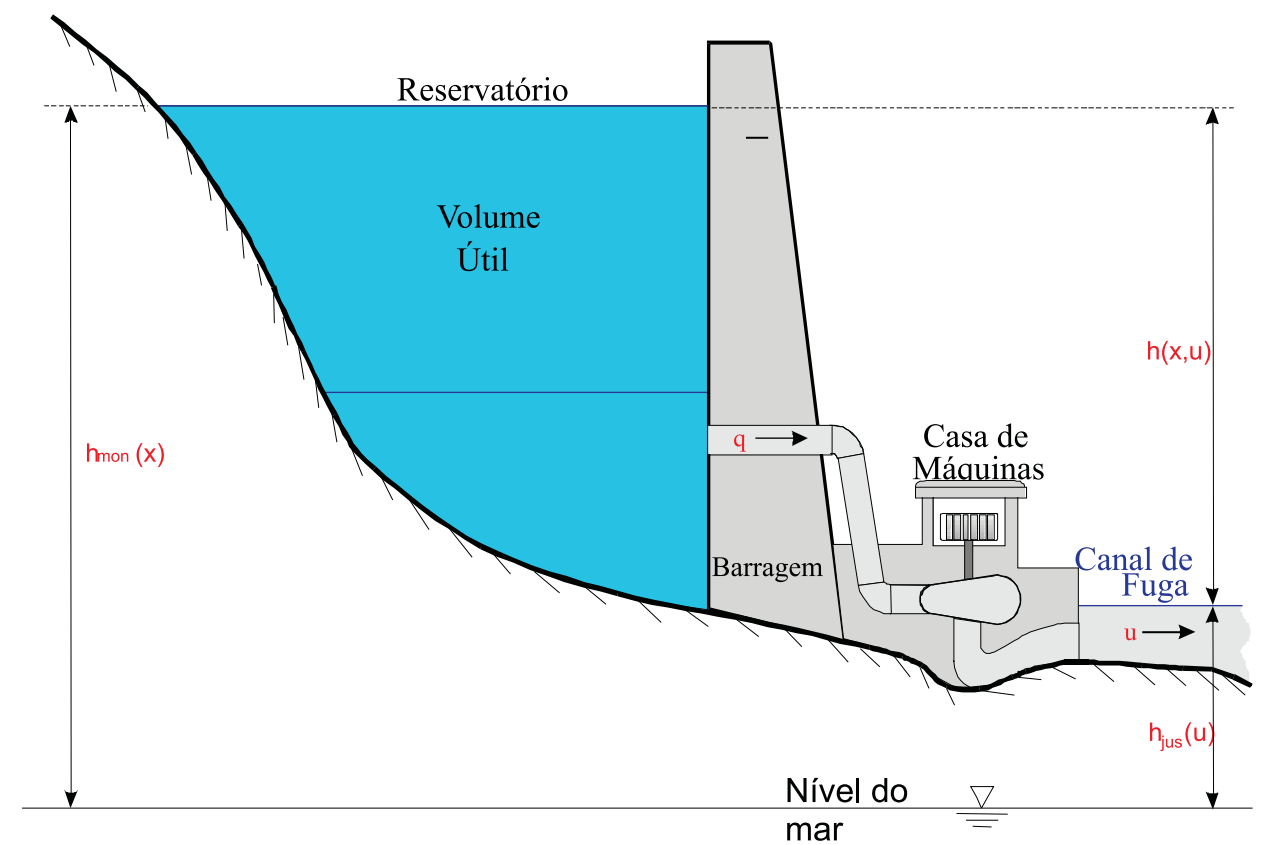

Figura 2.3: Perfil típico de uma usina hidroelétrica.

- $x(t)$ - volume do reservatório no instante $t$;

- $x_{\min }$ - volume mínimo do reservatório;

- $x_{m a ́ x}$ - volume máximo do reservatório;

- $x_{u}$ til - volume útil do reservatório;

- $q(t)$ - vazão turbinada pela usina no instante $t$;

- $z(t)$ - vazão vertida pela usina no instante $t$;

- $u(t)$ - defluência total da usina no instante $t, u(t)=z(t)+q(t)$

- $h_{m o n}(x)$ - nível d'água a montante do reservatório, função do volume de água acumulado; 
- $h_{j u s}(u)$ - nível d'água a jusante do reservatório, função da defluência total da usina;

- $h(x, u)$ - altura de queda bruta da usina, definida como a diferença entre as alturas a montante e a jusante do reservatório.

O volume $x$ equivale à quantidade de água armazenada no reservatório em um determinado instante. O volume mínimo $x_{m i n}$ é a menor quantidade de água armazenada no reservatório que permite o funcionamento da usina em condições normais de operação. O volume útil $x_{u}$ util é a diferença entre o maior volume suportado pelo reservatório em condições normais $x_{m a ́ x}$ e o volume mínimo.

A vazão turbinada $(q)$ representa a vazão que foi efetivamente utilizada na transformação de energia hidráulica em energia elétrica. Esta vazão é limitada pela turbinagem máxima, ou engolimento máximo, $\left(q_{m a ́ x}\right)$ da usina.

Adota-se a hipótese operativa de que uma usina só verte quando não puder mais turbinar. Desta forma, a vazão vertida $(v)$ ocorre quando a quantidade de água que chega à usina é maior que o engolimento máximo da mesma e o reservatório já encontrase cheio. Na operação real o vertimento também pode ocorrer em condições especiais de operação, como por exemplo no controle de cheias ou irrigação. Nestes casos a usina pode verter sem ter alcançado seu volume máximo.

A altura $h_{m o n}$ é a altura, em ralação ao nível do mar, do nível d'água a montante do reservatório. Esta altura é expressa em função do volume $(x)$. a altura $h_{j u s}$ é a altura, também em relação ao nível do mar, da água que encontra-se a jusante do reservatório e é expressa em função da defluência $(u)$. A altura $(h)$ é dada pela diferença entre as alturas a montante e a jusante e, evidentemente, é função tanto de $(u)$ quanto de $(x)$.

Após definidos alguns parâmetros necessários para uma melhor compreensão do problema, na seção 2.4 será apresentada a formulação matemática adotada na determinação da operação ótima do POSHP.

\subsection{Formulação Matemática do Problema}

O problema do Planejamento da Operação de Sistema Hidrotérmicos de Potência (POSHP) pode ser formulado através de um modelo de otimização, onde o custo 
de operação dos sistemas hidrotérmicos é dado pelas termoelétricas, já que as usinas hidroelétricas têm custo de operação quase nulo, a menos de taxas, visto que seu "combustível" é a água. Na realidade neste custo pode incluir eventuais importações de energia e o custo do déficit, sem prejuízo das considerações e análises feitas.

A seguir apresenta-se uma análise sobre a modelagem do problema, bem como, as formas de obtenção do custo marginal de operação e do valor marginal da água, conforme definido em [CARNEIRO (1991)].

O custo de operação de uma usina termoelétrica $\mathrm{C}(\mathrm{G})$, é dado por uma função convexa crescente, próxima de um polinômio de segundo grau, dado pela equação( 2.1).

$$
C(G)=a+b(G(t))+c(G(t))^{2}
$$

onde,

$G$ - potência ativa gerada;

$a, b, c$ - são parâmetros característicos da usina termoelétrica.

As restrições operativas são dadas pelos limites operacionais da usina:

$$
\underline{G} \leq G(t) \leq \bar{G}
$$

O conjunto de geração não hidráulico, que pode incluir a importação de energia e mesmo o corte de carga, pode ser modelado usando-se as funções de custo marginal para agregação em classes de térmicas. Desta forma, o custo de operação ótimo do conjunto não hidráulico é dado pela solução de um problema de despacho de geração, em um dado período, que procura igualar os custos marginais entre as fontes. Este custo é definido na seqüência de alocação da geração térmica e do déficit, pelo valor crescente dos respectivos custos marginais, das térmicas mais baratas para as mais caras [CARNEIRO (1991) e MARTINEZ (2001)]. Pode-se tomar, assim, uma função convexa crescente representando o custo de operação do conjunto das térmicas ou do sistema não hidráulico, como pode ser visto na Figura 2.4.

Para um subsistema composto por um conjunto de usinas térmicas sabe-se que o custo marginal em um intervalo é dado por $\lambda$, obtido pela agregação das disponibili- 


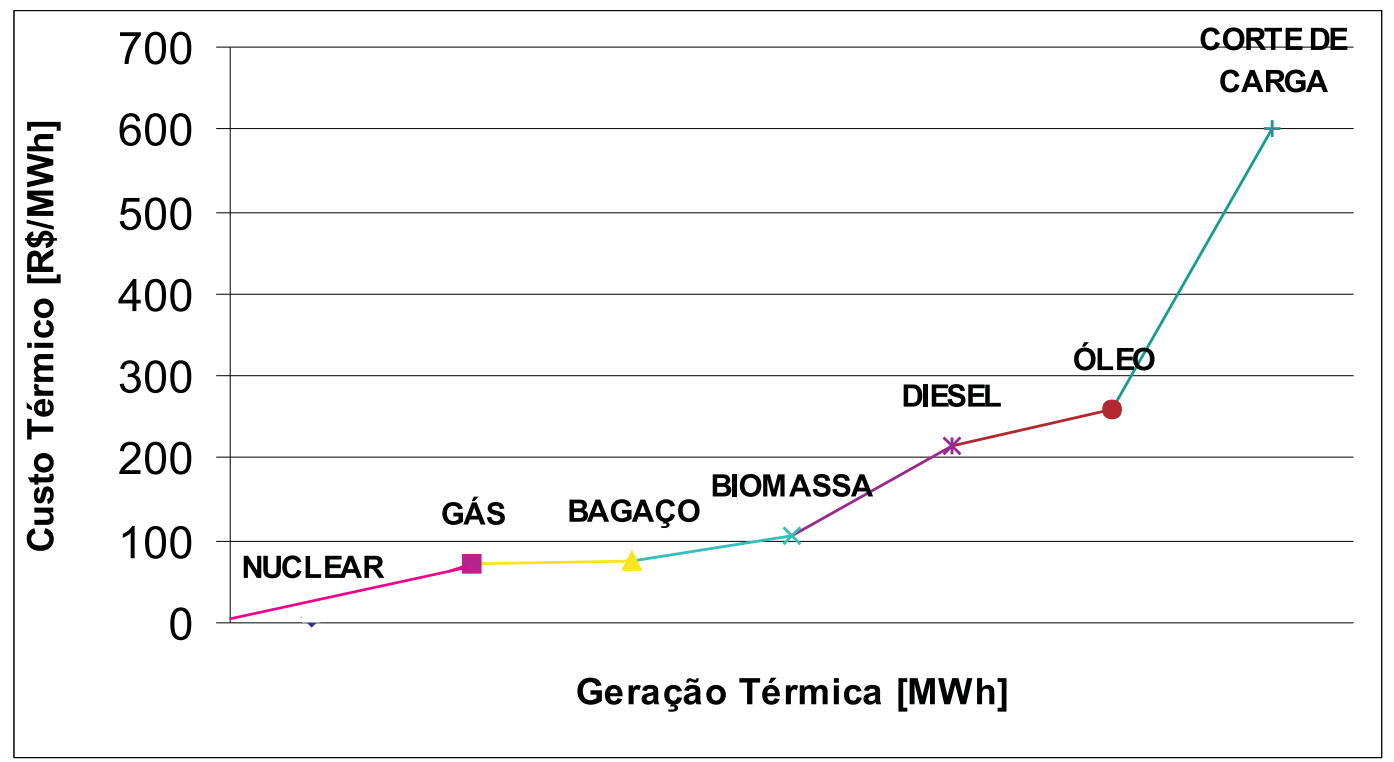

Figura 2.4: Custo de operação do sistema não hidráulico

dades térmicas. Portanto a função de custo marginal em um ponto é dada pela equação (2.3).

$$
\lambda=\left.\frac{\partial C[G(t)]}{\partial G(t)}\right|_{\hat{G}(t)} \quad \forall t
$$

Independentemente do combustível empregado nas usinas termoelétricas, o custo possui derivadas sempre positivas:

$$
\frac{\partial C[G(t)]}{\partial G(t)}>0
$$

O problema do Planejamento da Operação de Sistemas Hidrotérmicos de Potência, tem como custo de operação justamente o custo do sistema não hidráulico complementar, dado pela função $C($.$) , o qual depende obviamente da demanda total D$ do sistema e também da geração hidroelétrica $H$, pois quanto maior esta geração, menor será a complementação térmica necessária, admitindo-se que $D(t)=G(t)+H(t)$, onde:

$$
C=C[G(t)]
$$

onde:

$$
C(t)=C[D(t)-H(t)] \quad \text { para } \quad D(t) \geq H(t),
$$




$$
C(t)=0 \quad \text { para } \quad D(t)<H(t) .
$$

Com este modelo adotado, o planejamento hidrotérmico passa a ser um problema tratado exclusivamente através das usinas hidroelétricas.

Na pesquisa que foi desenvolvida, onde investiga-se Algoritmos Genéticos como técnica de resolução do POSHP, as suas variáveis são obtidas através de uma busca aleatória [LEITE et al. (2002b) e LEITE et al. (2002)]. Portanto, o cálculo do custo marginal de operação pode ser feito da forma tradicional, derivando-se analiticamente a função objetivo, externamente aos AGs, e substituindo-se os valores ótimos encontrados pelo algoritmo proposto.

De $D(t)=G(t)+H(t)$, vem:

$$
H[x(t), u(t)]=-G(t)
$$

Logo:

$$
\lambda(t)=-\left.\frac{d C D(t)-H[x(t), u(t)]}{d H[x(t), u(t)]}\right|_{\hat{H}(t)}=\left.\frac{\partial B D(t)-H[x(t), u(t)]}{\partial H(t)}\right|_{\hat{H}(t)} .
$$

onde:

$B[G(t)]=$ benefício resultante da utilização da água pela usina hidroelétrica, no intervalo $t$.

A equação (2.9) expressa ainda o custo marginal de operação, agora como função da geração hidroelétrica, mostrando-o como o decréscimo de custo, ou o benefício, que ocorreria caso houvesse um aumento incremental da geração hidráulica [CARNEIRO (1991)].

Da mesma forma, o valor da água em cada usina pode ser facilmente encontrado, já que a abordagem usada representa individualmente as usinas. Assim basta ponderar o custo marginal de operação do sistema pela geração marginal da usina hidroelétrica 
em relação à turbinagem no ponto ótimo, onde:

$$
\psi(t)=\left.\lambda(t) \frac{\partial H[x(t), u(t)]}{\partial u(t)}\right|_{\hat{u}(t)} .
$$

Isto pode ser entendido como uma igualdade na operação ótima, entre o benefício marginal de armazenar a água e o benefício marginal de defluir.

Como exemplo, e sem prejuízo de generalidade, no caso de se usar uma função de custo do tipo $C(G)=k[G(t)]^{2}$, tem-se:

$$
\frac{\partial C(G(t)}{\partial G(t)}=2 k G(t)
$$

Em sistemas com uma porcentagem substancial de geração hidroelétrica como no caso do Brasil pode-se utilizar a energia armazenada nos reservatórios do sistema para atender a demanda, substituindo assim a geração dispendiosa das unidades térmicas. Neste caso o valor da água em si, ou seja valor dessa energia gerada, é determinado pela geração termoelétrica, ou melhor, o valor da geração hidráulica em cada usina é dado pelo valor do que é substituído de energia termoelétrica.

A equação (2.12), reafirma o conceito do valor marginal da água, pode ser expresso como o decréscimo que se obteria no custo de operação, devido a um aumento incremental no uso da água pela usina hidráulica, em cada instante de tempo, ou seja, o benefício advindo de um acréscimo marginal no uso do recurso hídrico. Daí o conceito de que este valor representa, em termos marginais, o que a água conseguiria reduzir de custo pela substituição da geração termoelétrica por hidroeletricidade, na condição de operação ótima [CARNEIRO (1991)].

$$
\psi(t)=-\left.\frac{d C D(t)-H[x(t), u(t)]}{d u(t)]}\right|_{\hat{u}(t)}=\left.\frac{\partial B D(t)-H[x(t), u(t)]}{\partial u(t)}\right|_{\hat{u}(t)}
$$

Portanto, formulação geral do planejamento da operação energética de sistemas hidrotérmicos de potência não sofre nenhuma alteração. Esta pode ser estabelecida como a minimização do custo operacional do sistema, ao longo de todo o horizonte de 
planejamento $[1, T]$, dado por:

$$
\operatorname{Min} \sum_{t=1}^{T}[C(t)]
$$

s.a.

$$
\begin{gathered}
H(t)=\sum_{i=1}^{N} \phi\left[x_{i}(t), q_{i}(t), z_{i}(t)\right] \\
q_{i}(.)+z_{i}(.)=u_{i}(.) \\
\phi_{i}\left(x_{i}, q_{i}, z_{i}\right)=K_{i}\left[h_{1 i}\left(x_{i}\right)-h_{2 i}\left(q_{i}+z_{i}\right)\right] q_{i} \\
x_{i}(t+1)=x_{i}(t)+y_{i}(t)+\sum_{k \in \Omega_{i}}\left[q_{k}(t)+z_{k}(t)\right]-q_{k}(t)-z_{k}(t) \\
x_{i, \text { mim }}(t) \leq x_{i}(t) \leq x_{i, m a ́ x}(t) \\
q_{i}(t) \leq q_{i, \text { máx }}(t) \\
u_{i, \text { min }}(t) \leq q_{i}(t)+z_{i}(t)
\end{gathered}
$$

onde:

- $N$ - número de usina hidroelétricas;

- $\phi_{i}($.$) - função de geração hidroelétrica da usina i$;

- $x_{i}($.$) - volume do reservatório i$ no intervalo $t$;

- $q_{i}($.$) - vazão turbinada pela usina i$ no intervalo $t$;

- $z_{i}($.$) - vazão vertida da usina i$ no instante $t$; 
- $u_{i}($.$) - vazão defluída da usina i$ no instante $t$;

- $K_{i}$ - constante que engloba aceleração da gravidade, densidade da água, rendimento turbina-gerador e fatores de conversão de unidade;

- $h_{1 i}$ - altura de montante, em relação ao nível do mar, função do volume do reservatório;

- $h_{2 i}$ - altura de jusante, em relação ao nível do mar, função da vazão defluída total;

- $y_{i}(t)$ - afluência ao reservatório $i$ no instante $t$;

- $\Omega_{i}$ - conjunto de todas as usinas imediatamente a montante da usina $i$;

- $u_{i, m i ́ m}$ - representa a defluência total mínima obrigatória.

Além disso, os volumes iniciais dos reservatórios são dados e os volumes finais podem ser fixados e/ou penalizados.

Como ferramenta de resolução do problema determinado pelas Equações de (2.12) a (2.20), tradicionalmente, adota-se um algoritmo de otimização não-linear (PNL), que pode ser baseado em técnica de fluxo em rede, conforme Apêndice A, onde preserva-se a representação individualizada das usinas [CARNEIRO \& BOND (1990), CARNEIRO (1991), CARNEIRO et al. (1988), CARVALHO (1986) e CICOGNA \& SOARES (2003)].

Entretanto, esta linha de abordagem apresenta imperfeições maiores ou menores, dependendo do sistema aplicado, que levam à procura de novos caminhos [CICOGNA (1999), PEREIRA et al. (1987), LYRA et al. (1984) e CARNEIRO et al. (1988)]. Vários autores fizeram estudos comparativos entre as técnicas adotadas analisando as diversas formas de abordagens e mostrando as dificuldades de se abranger todos os aspectos da questão [ROSENTHAL (1980), FORTUNATO et al. (1985) e PEREIRA et al. (1987)].

As técnicas de resolução de otimização tradicionais apresentam dificuldades inerentes aos próprios métodos, como a necessidade de cálculo de derivadas, a inversão de matrizes, problemas de convergência, além de outras dificuldades devido à complexidade da função objetivo, já relacionadas no início do capítulo 2. 
Uma nova abordagem baseada em Algoritmos Genéticos é apresentada no Capítulo 6, na tentativa de buscar técnicas que forneçam melhores resultados para otimização da operação, principalmente em casos de sistemas complexos e de difícil solução.

Na próxima seção é apresentada a revisão bibliográfica realizada.

\subsection{Revisão Bibliográfica}

Abordagem utilizada para o problema do POSHP é muito influenciada pelas características de cada sistema, tais como predominância ou não de geração hidroelétrica, interligação das bacias, relevo, e outros. Além disso, a forma como o planejador equaciona o problema influi na abordagem adotada, fazendo com que sistemas com mesmas características apresentem formas diferentes de tratamento.

Quando adota-se uma modelagem para um problema e uma técnica de resolução, deve-se, além de considerar as características físicas do sistema, evitar simplificações drásticas, que deturpem os resultados, e levar em conta o nível de incerteza de cada horizonte.

Observe entretanto que esse é um problema estocástico, sendo necessário utilizar um algoritmo que considere esta característica inerente ao problema da operação energética de médio prazo. Uma técnica muito utilizada é a programação dinâmica estocástica (PDE)[BELLMAN (1962)], nos seus mais variados modelos. Porém, esta técnica apresenta a maldição da dimensionalidade, causada pelo aumento exponencial dos estados possíveis, a medida que aumenta o número de usinas. Se as variáveis de volume e vazão defluída de cada usina, de um conjunto de $N$ usinas, forem discretizadas em $M$ intervalos, existirão $M^{2 N}$ estados possíveis no espaço de estado, o que, mesmo para um número pequeno de usinas, implica em grande esforço computacional [SILVA (2001) e PEREIRA (1985)]. Assim, em sistemas com múltiplas usinas não será possível empregar a programação dinâmica, devido à sua dimensão excessiva.

Uma das tentativas adotadas para solucionar o número excessivo de variáveis de estado envolve o uso de modelo agregado, no qual o valor energético da água armazenada em um reservatório é função das alturas de quedas acumuladas nos reservatórios a jusante. Desta forma, a capacidade total de armazenamento do modelo agregado é expressa em termos de energia e não do volume de água armazenado no sistema. Este 
modelo é também conhecido como modelo a sistema equivalente, pois os vários reservatórios são transformados em um único reservatório equivalente de energia potencial [DURAN et al. (1985)]. O uso deste método permite uma abordagem estocástica do problema, mas penaliza a representação individualizada das usinas.

Outra metodologia utilizada consiste no uso da Programação Dinâmica Estocástica Dual (PDED), a qual pode ser caracterizada como uma extensão da PDE. A PDED permite reduzir o esforço computacional na solução do problema, trazendo, então, a possibilidade de se representar o sistema hidráulico mais detalhadamente. Esta metodologia tem sido empregado para o sistema brasileiro, utilizando uma representação a múltiplos reservatórios, cada um deles correspondendo a um subsistema [MACIEIRA et al. (2003) e $\operatorname{SILVA}(2001)]$.

Vários métodos também têm sido propostos, baseados em programação não-linear. Através desta técnica, mesmo em sistemas com grande porte, pode-se fazer a representação individualizada das usinas [ROSENTHAL (1980) e CARNEIRO \& BOND (1990)]. Entretanto, esta abordagem apresenta diversas dificuldades, principalmente devido à complexidade da função objetivo, mormente no Sistema Brasileiro, onde as alturas de queda das usinas em geral dependem dos volumes de água armazenados, além de não permitirem uma representação estocástica explícita para as vazões afluentes.

A proposta da utilização de métodos de linearização e técnicas de programação quadrática aplicadas ao problema da operação tem como vantagem o uso do método Simplex na resolução, preservando as características individuais de cada usina [CARNEIRO \& ZAMBON (1997) e ZAMBON (1998)].

Com relação à aplicação de IA ao planejamento da operação, destaca-se o trabalho que utilizou ferramenta baseada em Algoritmos Genéticos, na coordenação da operação de sistema, considerando um sistema composto por 22 usinas térmicas e 3 hidroelétricas em um horizonte de 24 horas. Os autores afirmaram que obtiveram resultados mais satisfatórios que os obtidos pela programação dinâmica e que há ainda a possibilidade de trabalhar com um horizonte de uma semana [CHEN \& CHANG (1996)].

Cabe apontar também o trabalho que descreve o uso de uma técnica de programação evolucionária no planejamento de curto prazo de geração hidrotérmica [YANG et al. (1996)]. Neste trabalho foi feita a comparação da técnica proposta com outras técnicas utilizadas para resolução do problema apontado. 
Foi proposto também um trabalho baseado em Algoritmos Genéticos para operação de um sistema fictício composto por 8 usinas em um horizonte de planejamento de um ano. Os autores consideram que a vantagem do uso desta técnica na possibilidade de adaptar a estratégia de operação de acordo com a afluência de água atual. Entretanto, esta não é uma aplicação verdadeira e os próprios autores alertam que somente com dados e situações reais poderiam chegar a conclusões mais definitivas [MIRANDA et al. (1998)].

Em [CHANG \& CHEN (1998)] foi desenvolvido um trabalho que utiliza AGs para a determinação do despacho de geração hidrotérmica. A vantagem apontada pelos autores é que os AGs conseguiram superar as dificuldades impostas pela restrição de balanço d'água. Eles apontam com segurança, através dos resultados obtidos, que técnicas de IA tendem a ser aplicadas com mais intensidade na área de POSHP.

Os AGs têm provado serem versáteis e eficazes na resolução de problemas de otimização. Entretanto, existem situações nas quais um algoritmo genético simples pode não mostrar um bom desempenho. Por este motivo, vários métodos de hibridização vêm sendo propostos [GEN \& CHENG (1989)].

Em [GOLDBERG (1997)] foi usado a idéia de G-bit melhorando o string binário, onde é feita a incorporação de movimentos extra de operadores [DAVID (1991)]. A utilização de um Algoritmo Genético "Hill-climbing" é recomendada em [GEN \& CHENG (1989)], no qual o cruzamento têm um domínio menor e a sua vizinhança é mais explorada [ACKLEY (1987)]. Alguns autores afirmam teoricamente, com demonstrações empíricas, que a busca local pode ser uma grande aliada na investigação de abordagens eficientes [REEVES (1993)].

Os Sistemas Genéticos Híbridos mais comuns são aqueles que combinam otimização local com um simples AG. A otimização local é aplicada a cada indivíduo de uma nova geração. Pode-se dizer neste caso que os AGs exploram uma população de soluções e os métodos de busca local (heurísticos) exploram cada indivíduo da população, ou seja, cada possível solução para o problema. Sistemas híbridos freqüentemente apresentam um bom desempenho em comparação a métodos isolados. Alguns estudos estão sendo desenvolvidos sobre algoritmos híbridos que utilizam mecanismos naturais. Entre eles destacam-se: Evolução Lamarquiana [URDENETA et al. (1999)] Algoritmos Meméticos [GEN \& CHENG (1989)]. 
A seguir serão apresentados comentários a respeito de trabalhos referentes a Sistemas Genéticos Híbridos.

Uma formulação utilizando Lógica Fuzzy foi desenvolvida para o planejamento da geração de curto-prazo (24 horas). Em seguida foi realizada uma combinação desta técnica com AGs e Simulated Annealing (SA)[WONG \& WONG (1996)]. Através dos casos testes, chegou-se a conclusão que o conjunto fuzzy combinado com SA e AGs, tendo uma população com apenas 2 indivíduos, apresentou melhor desempenho, o que ocorreu devido ao uso de uma técnica híbrida.

Uma metodologia híbrida é apresentada para a solução do problema de alocação de fontes de potência reativa em [URDENETA et al. (1999)]. A técnica, em um primeiro estágio, utiliza um algoritmo genético com operador Larmaquiano que, segundo os autores, melhora a otimização do algoritmo. Em seguida é aplicado um método de programação linear, o Simplex, que interage com um método de fluxo de carga de desacoplamento rápido para resolução de equações não-lineares. Os passos do algoritmo desenvolvido são mostrados na Figura 2.5. O artigo trata da minimização do custo da instalação de novas fontes de potência reativa e o algoritmo foi aplicado em um sistema pertencente a rede elétrica da Venezuela, onde bons resultados foram obtidos.

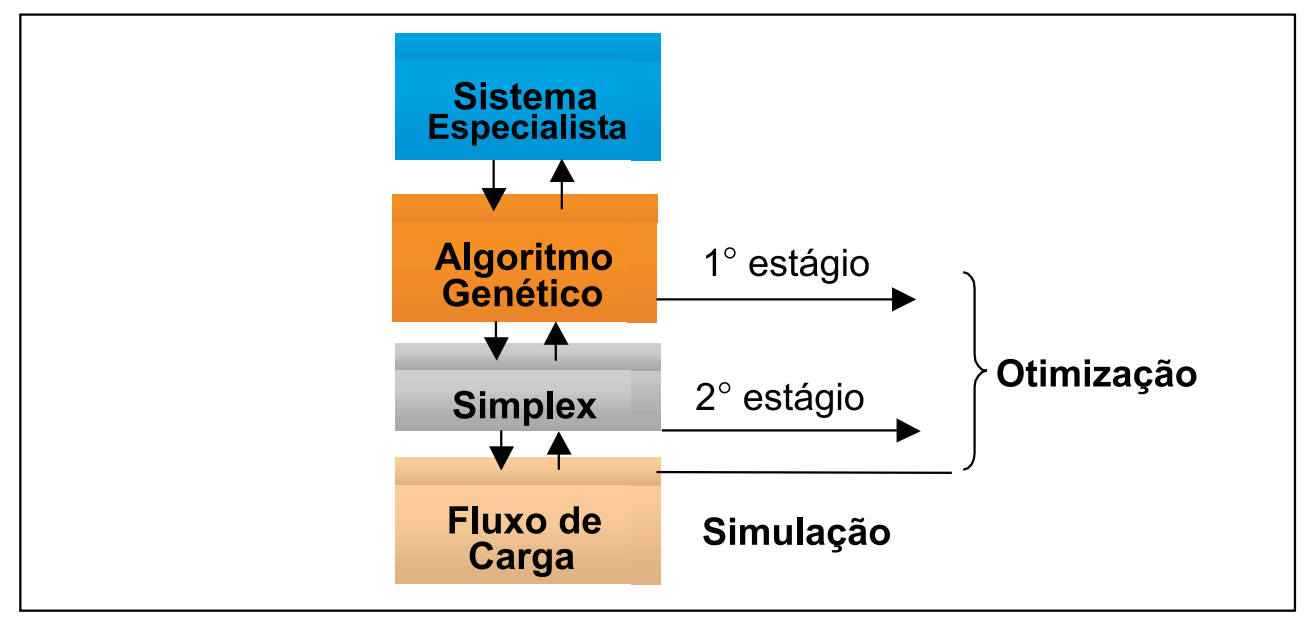

Figura 2.5: Fluxograma do Algoritmo desenvolvido utilizando 2 estágios.

Um trabalho que integra AGs, Tabu Search (TS) e Simulated Annealing (SA) para solucionar o problema da geração é apresentado em [MANTAWY et al. (1999)]. O algoritmo proposto é baseado em AGs. Os autores utilizam TS para gerar novos membros 
na população, na fase de reprodução, e SA para acelerar a convergência do algoritmo. Neste trabalho foi adotada uma nova implementação, onde os códigos do AGs misturam codificações binária e decimal na sua representação. Os resultados numéricos mostram que a utilização das técnicas em conjunto apresentaram melhor desempenho do que quando adotadas técnicas individuais.

Em um trabalho sobre ampliação dos Algoritmos Genéticos para resolução de problemas ditos de alto nível, como problemas complexos de planejamento e alocação de memória [GREWAL \& WILSON (2000)], são utilizados dois novos operadores. O primeiro é a mutação direcionada, ou seja, tendo-se um prévio conhecimento do atendimento das restrições, pode-se induzir a solução ótima ou quase ótima do problema, conforme mostrado na Figura 2.6.

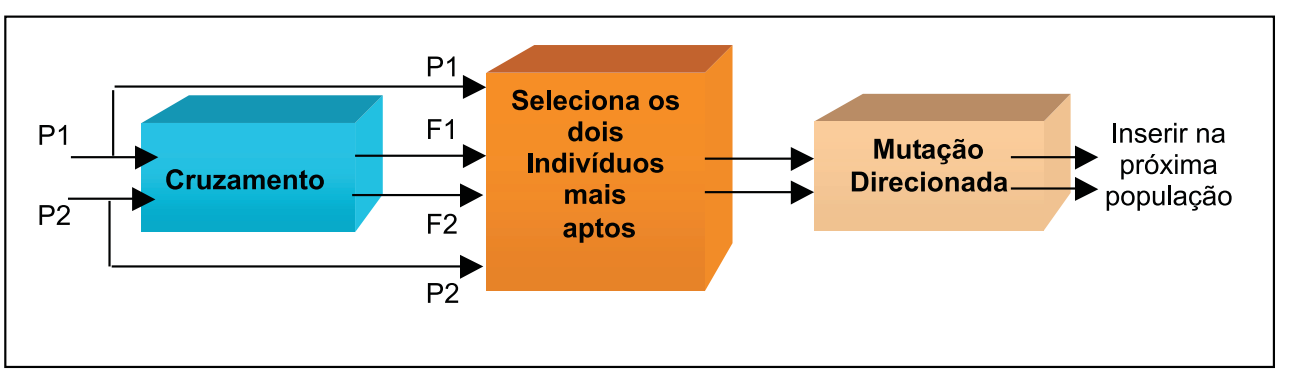

Figura 2.6: Mutação direcionada.

O segundo operador proposto foi o do elitismo parcial, que tem como objetivo fazer com que os melhores indivíduos passem para a próxima população, após aplicação dos operadores genéticos, como mostrado na Figura 2.7, diferentemente do elitismo tradicional, onde o melhor passa para a população sem alterar suas características, no inicio da geração. Logo, utilizando este novo operador, após a realização do cruzamento, é feita uma comparação entre os pais e seus descendentes e somente os dois melhores indivíduos deste conjunto passarão para a próxima geração. Para os problemas tratados, houve uma rápida convergência, após algumas gerações, pois a população era composta apenas pelos melhores indivíduos.

Em [HE et al. (2000)], os autores utilizam sistemas híbridos na resolução de problemas de equação linear e equação diferencial parcial. O bom desempenho mostra que as técnicas tradicionais, que apresentam dificuldades inerentes ao próprio método, quando associadas a computação evolucionária transformam-se em ferramentas eficazes na res- 


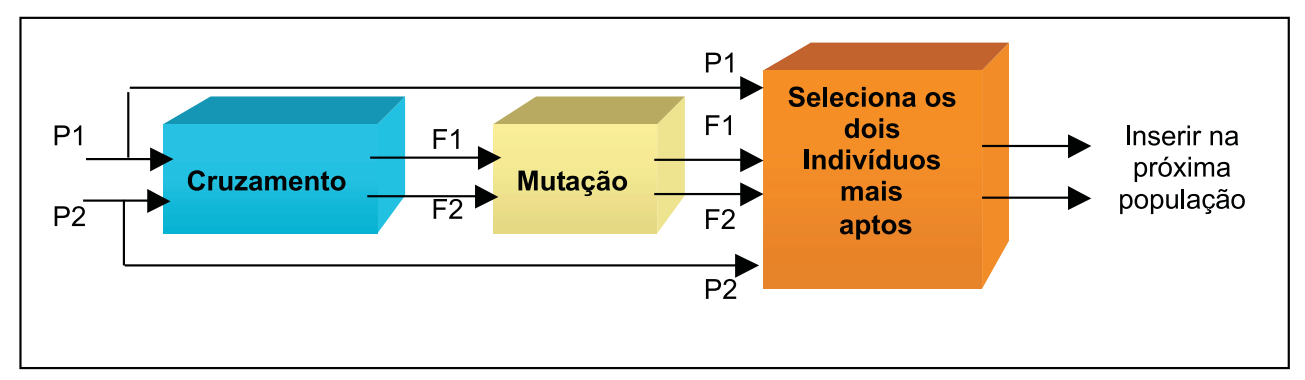

Figura 2.7: Elitismo parcial.

olução de problemas de otimização. Eles acreditam que estes métodos híbridos são mais eficientes, robustos e de fácil implementação.

Uma análise sobre Algoritmos Evolucionários e Método do Gradiente é apresentada em [SALOMON (1998)]. Neste trabalho, discutem as similaridades e diferenças entre essas duas técnicas. As conclusões têm sido utilizadas para exploração de Algoritmos Híbridos, que vêm apresentando grande eficiência na resolução de problemas complexos.

Soluções para sistemas de equações não lineares estão entre as maiores dificuldades para a computação numérica. Isto também ocorre com freqüência em problemas de engenharia, tais como: geração e distribuição de energia, otimização multi-objetivo, etc. Vários métodos clássicos foram desenvolvidos e, no artigo em questão [KARR et al. (1998)], utilizou-se o conhecido Método de Newton em conjunto com os Algoritmos Genéticos, para resolver equações não-lineares.

Baseado na revisão bibliográfica apresentada, acredita-se que a utilização de Sistema Genético Híbrido, acarretará em um algoritmo mais eficiente para a resolução do problema POSHP, tratado de forma determinística e representando cada usina do sistema hidroelétrico individualmente, com suas próprias restrições operacionais.

No capítulo 3, será mostrada a definição dos AGs e no capítulo 4 apresenta-se o algoritmo proposto. 


\section{Capítulo 3}

\section{Algoritmos Genéticos}

\subsection{Introdução}

A introdução aos principais conceitos de uma área de Inteligência Artificial inspirada na Teoria da Evolução Natural e na Genética, conhecida como Computação Evolutiva, ou Evolucionária, será apresentada neste capítulo.

A Computação Evolutiva (CE) pode ser dividida nas seguintes subáreas: Algoritmos Genéticos, Estratégias de Evolução e Programação Genética [MICHALEWICZ et al. (1996)] e [MICHALEWICZ et al. (2000)].

Neste trabalho será discutida apenas a subárea referente aos Algoritmos Genéticos (AGs). Está técnica foi utilizada para resolver o problema do Planejamento da Operação de Sistemas Hidrotérmicos de Potência [LEITE et al. (2002b)] e [REZENDE (2003)].

Vários trabalhos vêm sendo desenvolvidos com aplicação de técnicas de Algoritmos Genéticos, as quais são extremamente interessantes como ferramentas de busca e otimização na solução dos mais diferentes tipos de problemas [BEASLEY et al. (1993), BEASLEY et al. (1993b), WHITLEY (1993) e REZENDE (2003)].

Algoritmos Genéticos são programas evolutivos inspirados na Teoria de Seleção Natural. Eles atuam sobre uma população de indivíduos baseados no fato de que os indivíduos com boas características genéticas têm maiores chances de sobrevivência e de produzirem indivíduos cada vez mais aptos, enquanto os indivíduos menos aptos tendem a desaparecer. Os Algoritmos Genéticos trabalham sempre com as áreas mais promissoras do espaço de busca [GALVÃO \& VALENÇA (1999)] e [HAUP \& HAUP 
(1998)]. Vale lembrar que os AGs são uma classe de procedimentos, com um conjunto de passos distintos e bem especificados, na qual cada um destes passos possui muitas variações possíveis .

Nos AGs, normalmente, cada indivíduo da população, chamado cromossomo, corresponde a uma solução para um dado problema. Um mecanismo de reprodução, baseado em processo evolutivo, é aplicado sobre a população atual com o objetivo de explorar o espaço de busca e encontrar melhores soluções para o problema [RABELO \& OCHI (1996)].

Toda tarefa de busca ou otimização possui vários componentes, entre eles o espaço de busca, onde são consideradas todas as possibilidades de solução de um determinado problema, e a função de avaliação, ou função de custo, uma maneira de avaliar as soluções no espaço de busca. Existem muitos métodos de busca e funções de avaliação [GOLDBERG (1997)].

Os métodos e técnicas de busca e otimização tradicionais iniciam-se com um único candidato, que iterativamente é manipulado utilizando, geralmente, métodos determinísticos para resolução de um problema [WINSTON (1992)].

Por outro lado, as técnicas de computação evolucionária operam sobre uma população de candidatos em paralelo. Assim, elas podem fazer a busca em diferentes áreas do espaço de soluções, alocando um número de soluções apropriadas para busca em várias regiões. Portanto, tais técnicas têm maiores chances de atingir as áreas mais promissoras do espaço de busca. Os AGs diferem dos métodos tradicionais de busca e otimização, principalmente em quatro aspectos [GOLDBERG (1997) e REZENDE (2003)]:

1. os Algoritmos Genéticos trabalham com uma codificação do conjunto de parâmetros e não com os próprios parâmetros;

2. os Algoritmos Genéticos trabalham com um espaço de busca, onde estão todas as possíveis soluções do problema e não um único ponto;

3. os Algoritmos Genéticos utilizam informação de custo ou recompensa e não derivadas ou outro conhecimento auxiliar;

4. os Algoritmos Genéticos utilizam regras de transição probabilísticas e não deter- 
minísticas.

Os AGs são muito eficientes para busca de soluções ótimas, ou aproximadamente ótimas, em uma grande variedade de problemas, pois não impõem muitas das limitações encontradas nos métodos de busca tradicionais. Baseiam-se na evolução biológica e são capazes de identificar e explorar fatores ambientais e convergir para soluções ótimas em níveis globais, contornando a ocorrência de ótimos locais. Além de seguir uma estratégia de gerar e testar soluções muito elegantes, são capazes de identificar e explorar aspectos do ambiente onde o problema está inserido e convergir globalmente para soluções ótimas ou aproximadamente ótimas [GOLDBERG (1997) e HOLLAND (1992)].

Os AGs baseiam-se inicialmente na geração de uma população formada por um conjunto aleatório de indivíduos que podem ser vistos como possíveis soluções do problema. Durante o processo evolutivo, esta população é avaliada: para cada indivíduo é dado um índice, refletindo sua habilidade de adaptação a determinado ambiente. Uma porcentagem dos mais adaptados é mantida, enquanto os outros são descartados. Os membros mantidos pela seleção podem sofrer modificações em suas características, através de mutações e recombinação, gerando descendentes para a próxima geração. Este processo, chamado de reprodução, é repetido até que um conjunto de soluções satisfatórias seja encontrado, conforme apresentado no Algoritmo 1.

\section{Algoritmos 1: Algoritmo Genético típico}

Seja $S(t)$ a população de indivíduos na geração $t$.

$t \leftarrow 0$

inicializa $S(t)$

avaliar $S(t)$

enquanto o critério de parada não for satisfeito faça

$$
t \leftarrow t+1
$$

selecionar $S(t)$ a partir de $S(t-1)$

aplicar recombinação sobre $S(t)$

aplicar mutação sobre $S(t)$

avaliar $S(t)$

Fim enquanto

Embora possam parecer simplistas do ponto de vista biológico, esse algoritmos são 
suficientemente complexos para fornecer mecanismos poderosos e robustos de busca adaptativa [COELHO (2003) e GOLDBERG (1997)].

\subsection{Histórico}

"A origem da vida, sempre foi um grande desafio para o ser humano, não tanto por seus mistérios mas pelo vasto campo de pesquisa que se abre na tentativa de entender os processos que cercam o universo e a sua existência. Com o avanço das pesquisas neste campo, hoje mais do que nunca, aliado à tecnologia que a cada dia se torna mais inovadora, o homem percebe e sente a existência de algo que transcede a concepção trivial de "vida", tornando-o mais crítico sobre coisas que o cercam. Entretanto, a criação da vida é algo por demais complexo, que envolve não apenas uma sucessão de eventos dentro de uma escala cronológica, mas também muitos outros aspectos teológicos e filosóficos. E, mesmo que a capacidade de compreensão do homem seja muito extensa, a origem da vida continua a ser um mistério em nosso século quase que insondável e inexplicável, ainda que exaustivamente pesquisado" [MENDES et al. (1989) e LEWIS (2001)].

"Até meados do século 19, o mundo acreditava que cada espécie havia sido criada separadamente por um ser supremo ou através de geração espontânea. O trabalho do naturalista Carolus Linnaeus, sobre a classificação biológica de organismos, despertou o interesse pela similaridade entre certas espécies, levando a acreditar na existência de uma certa relação entre elas. Outros trabalhos influenciaram os naturalistas em direção à teoria da seleção natural, tais como os de Jean Baptiste Lamark, que sugeriu uma teoria evolucionária do "uso e desuso" de órgãos e de Thomas Robert Malthus, que propôs que fatores ambientais, tais como doenças e carência de alimentos, limitavam o crescimento de uma população" [MENDES (1997)].

Cronologicamente alguns eventos marcaram o desenvolvimento nesta área, como descritos a seguir:

1833 - a teoria da evolução e a computação nasceram praticamente na mesma época. Charles Babbage, um dos fundadores da computação moderna e amigo pessoal de Darwin, desenvolveu sua máquina analítica.

1858 - Charles Darwin apresentou sua teoria de evolução através de seleção natural, 
na mesma época em que o naturalista inglês Alfred Russel Wallace. Segundo Darwin, mutações estão presentes em todas as espécies; a evolução ocorre devido a uma força chamada de seleção natural que escolhe os indivíduos melhores adaptados ao ambiente; em um ambiente constante, as espécies preservarão suas identidades; em um ambiente mutável, alguns indivíduos serão melhores que os originais e serão preservados (criação de novas espécies).

1859 - Darwin publica "On the Origin of Species by Means of Natural Selection" com a sua teoria completa. Este trabalho influenciou muito o futuro não apenas da Biologia, Botânica e Zoologia, mas de todo o pensamento relacionado à vida.

1900 - o trabalho de Gregor Mendel, desenvolvido em 1865, sobre os princípios básicos de herança genética, foi redescoberto pelos cientistas e teve grande influência sobre os futuros trabalhos relacionados à evolução.

Entre 1930 e 1940 a moderna teoria da evolução combina a genética e as idéias de Darwin e Wallace sobre a seleção natural, criando o princípio básico de Genética Populacional: "a variabilidade entre indivíduos em uma população de organismos que se reproduzem sexualmente é produzida pela mutação e pela recombinação genética". Este princípio foi desenvolvido por biólogos e matemáticos de importantes centros de pesquisas.

No período de 1950 a 1960 muitos biólogos começaram a desenvolver simulações computacionais de sistemas genéticos.

Em 1975 John Holland começou a desenvolver as primeiras pesquisas e publicou o seu livro "Adaptation in Natural and Artificial Systems".

Desde então, os Algoritmos Genéticos vêm sendo aplicados com sucesso nos mais diversos problemas de otimização e aprendizado de máquinas [ALANDER (2001) e WINSTON (1992)].

\subsection{Terminologia}

Baseado na teoria da evolução, pode-se dizer que o meio ambiente é o responsável pela seleção em cada geração dos seres vivos mais aptos de uma população. Logo, somente os mais aptos conseguem passar suas características genéticas para as demais 
gerações, pois os menos adaptados são eliminados antes de gerarem descendentes. No processo de reprodução são aplicados os operadores genéticos de mutação e cruzamento, entre outros, que atuam sobre o material genético armazenado nos cromossomos e, com isso, tem-se a variabilidade dos indivíduos na população. A sobrevivência do mais adaptado é determinada pela seleção natural.

Um Algoritmo Genético sofre grande influência da biologia, em suas definições, isso explica muitos termos semelhantes, utilizados por este método [GALVÃO \& VALENÇA (1999)].

A seguir serão apresentados alguns termos comumente encontrados na literatura.

- Cromossomo: segmento do filamento cromático que se destaca por ocasião da divisão celular indireta, constituindo unidades definidas na formação do novo ser. Nos AGs este representa a estrutura de dados que codifica uma solução para um problema, ou seja, um indivíduo no espaço de busca.

- Gene: partícula do cromossomo em que se encerram os caracteres hereditários. Nos AGs, é um parâmetro codificado no cromossomo, ou seja, um elemento do vetor que representa o indivíduo.

- Genótipo: constituição hereditária de um indivíduo. Nos AGs, representa a informação contida no indivíduo.

- Fenótipo: diz-se dos indivíduos de um grupo que apresentam caracteres exteriores iguais, mas que diferem pelo seu genótipo. Nos AGs, representa o objeto, estrutura ou organismo construído a partir das informações do genótipo, ou seja, a decodificação do indivíduo.

Uma comparação entre terminologia biológica, terminologia computacional e terminologia do Planejamento da Operação ${ }^{1}$, a ser utilizada nos Algoritmos Genéticos é apresentada na Tabela 3.1

A seguir serão abordados alguns operadores genéticos tradicionais, comumente utilizados na literatura.

\footnotetext{
${ }^{1}$ Maiores detalhes sobre a codificação do problema do POSHP encontra-se no Capítulo 4
} 
Tabela 3.1: Terminologia Biológica x Terminologia Computacional x Terminologia do Planejamento da Operação.

\begin{tabular}{|l||l||l|}
\hline Biologia & Computação & Planejamento da Operação \\
\hline Cromossomo & $\begin{array}{l}\text { Representa um candidato à solução, } \\
\text { ou seja, um ponto no espaço de } \\
\text { busca. }\end{array}$ & $\begin{array}{l}\text { Representa conjunto de volumes } \\
\text { úteis de uma usina no período } \\
\text { de planejamento, por exemplo 12 } \\
\text { meses. }\end{array}$ \\
\hline Gene & $\begin{array}{l}\text { É um parâmetro codificado no cro- } \\
\text { mossomo (um único bit, ou um } \\
\text { bloco de bits) }\end{array}$ & $\begin{array}{l}\text { É o volume útil de uma usina em } \\
\text { cada mês do período de planeja- } \\
\text { mento. }\end{array}$ \\
\hline Recombinação & $\begin{array}{l}\text { Troca de material genético entre } \\
\text { cromossomos }\end{array}$ & $\begin{array}{l}\text { Troca de volume útil entre os cro- } \\
\text { mossomos da usina. }\end{array}$ \\
\hline Mutação & $\begin{array}{l}\text { Troca aleatória de um determinado } \\
\text { gene do cromossomo }\end{array}$ & $\begin{array}{l}\text { Acréscimo ou decréscimo do volume } \\
\text { útil de uma usina. }\end{array}$ \\
\hline Genótipo & $\begin{array}{l}\text { Configuração de genes no cromos- } \\
\text { somo de um indivíduo. }\end{array}$ & $\begin{array}{l}\text { Codificação do volume útil ar- } \\
\text { mazenado no reservatório. }\end{array}$ \\
\hline Fenótipo & $\begin{array}{l}\text { Decodificação de um ou mais cro- } \\
\text { mossomos. }\end{array}$ & $\begin{array}{l}\text { Decodificação do volume operativo } \\
\text { de uma usina em um determinado } \\
\text { período de planejamento. }\end{array}$ \\
\hline
\end{tabular}

\subsection{Características gerais e representação}

A aplicação de operadores genéticos tem como objetivo a produção de novos indivíduos a partir de indivíduos existentes. O principio básico dos operadores é fazer com que a população, através de sucessivas gerações, estenda a busca até chegar a um resultado satisfatório. A grande utilidade destes operadores é fazer com que a população se diversifique e mantenha características de adaptação adquiridas pelas gerações anteriores.

Quando se trabalha com Algoritmos Genéticos para resolução de problemas, o grande desafio está exatamente na codificação, ou qual a melhor maneira de representar o problema, que deve ter uma estrutura de dados, geralmente vetores ou cadeias de valores binários (estruturas mais tradicionais, porém nem sempre as mais indicadas), reais ou inteiros. Esta estrutura é chamada de indivíduo ou cromossomo, e cada bit chamado de gene.

O indivíduo representa o conjunto de parâmetros de variáveis da função objetivo cuja resposta será maximizada ou minimizada. O conjunto de todas as configurações que o indivíduo pode assumir forma o espaço de busca. Por exemplo, se o indivíduo 
representa $n$ parâmetros de uma função, então o espaço de busca é uma espaço com $n$ dimensões. A maioria das representações genotípicas, utilizam vetores de tamanho finito com um alfabeto também finito [REZENDE (2003)].

Normalmente, o genótipo de um indivíduo é representado por um vetor binário, onde cada elemento do vetor denota uma ou outra característica de uma determinada característica. Os elementos podem ser combinados formando as características reais do indivíduo, ou seja, o seu fenótipo. Portanto, essa representação é independente do problema, pois uma vez encontrada a representação em vetores binários, as operações padrão podem ser utilizadas, facilitando o seu emprego em diferentes classes de problemas [SPEARS et al. (1993)].

A representação binária é historicamente importante, uma vez que foi utilizada nos trabalhos pioneiros de John Holland. Além disso, ela ainda é a representação mais utilizada, por ser de fácil utilização, manipulação e simplicidade de analisar teoricamente. Contudo, se um problema tem parâmetros contínuos e o usuário desejar trabalhar com maior precisão, provavelmente acabará utilizando longos indivíduos para representar soluções, necessitando de uma grande quantidade de memória. Outro aspecto a ser observado é a não-uniformidade dos operadores; por exemplo, se o valor real de um gene for codificado por um vetor binário, a mutação nos primeiros valores binários do gene afetará mais a aptidão do individuo que a mutação nos seus últimos valores [REZENDE (2003)].

A aptidão do indivíduo depende do seu desempenho e é calculada através da função de avaliação. Em problemas de otimização, a função objetivo é, ela mesma, a candidata natural ao cargo de função de avaliação ou função de aptidão. Assim, pode-se dizer que a função de avaliação é dependente do problema em particular. Esta função recebe como entrada o indivíduo e faz o cálculo da aptidão, ou grau de adaptação, retornando esta informação.

\subsection{Seleção}

Nos AGs, é aplicado um critério de seleção para que o conjunto inicial de indivíduos gere descendentes mais aptos. Quando não existe nenhum conhecimento prévio sobre a região do espaço de busca onde se encontra a solução do problema na população inicial, 
os indivíduos são gerados aleatoriamente. Se houver um conhecimento prévio sobre a região em que está localizada a solução, ou seja, se forem conhecidas soluções aceitáveis que podem estar próximas à(s) solução(ões) ótima(s), os cromossomos iniciais podem ser definidos de forma determinada.

Com intuito de privilegiar os indivíduos mais aptos no processo de seleção, a cada membro da população é atribuído um valor dado por uma função $f_{\text {apt }}$ denominada função de aptidão. Esta função recebe como entrada os valores do gene do indivíduo e fornece como resultado sua aptidão. A aptidão pode ser vista como uma nota que mede o quão boa é a solução codificada por um indivíduo e é baseada no valor da função-objetivo, que é específica para cada problema.

Para alguns métodos de seleção, é desejável que o valor de aptidão de cada indivíduo seja menor que 1 e que a soma de todos os valores de aptidão seja igual a 1 $\left(f_{\text {apto }}<1\right.$ e $\sum\left(f_{\text {apto }}=1\right)$. Para isso, para cada indivíduo é calculada a aptidão relativa $\left(f_{r e l}\right)$. A aptidão relativa para um dado indivíduo é obtida dividindo o valor de sua aptidão pela soma dos valores de aptidão de todos os indivíduos da população.

A função objetivo, também conhecida por função de avaliação ou função de custo é geralmente uma expressão matemática que mede o quanto uma solução está próxima ou distante da solução desejada (satisfaz o objetivo do problema). Muitas vezes ela inclui restrições que devem ser satisfeitas pela solução.

No processo de seleção, após associada uma nota de aptidão a cada indivíduo da população, escolhe-se então um subconjunto de indivíduos da população atual, gerando uma população intermediária. Vários métodos de seleção têm sido propostos, entre eles se destacam tradicionalmente: Método da Roleta, Método do Torneio e o Método da Amostragem Universal Estocástica [REZENDE (2003) e COELHO (2003)].

\subsection{Operadores Genéticos}

Dada uma população, para que seja possível gerar populações sucessivas que, esperase, melhorem sua aptidão com o tempo, é necessária a aplicação de operadores genéticos. Estes operadores são: recombinação e mutação. Eles são utilizados para assegurar que a nova geração seja renovada, mas possua, de alguma forma, características de seus pais; e são úteis para que a população se diversifique e mantenha características de adaptação 
adquirida pelas gerações anteriores. Para prevenir que os melhores indivíduos não desapareçam da população pela manipulação dos operadores genéticos, eles podem ser colocados automaticamente na próxima geração por meio de uma política elitista. O princípio básico dos operadores genéticos é, então, transformar a população por meio de sucessivas gerações, estendendo a busca até chegar a um resultado satisfatório.

O operador de mutação é necessário para a introdução e manutenção da diversidade genética da população, alterando arbitrariamente um ou mais componentes de uma estrutura escolhida, o que fornece meios para introdução de novos elementos na população. Desta maneira, a mutação assegura que a probabilidade de chegar a qualquer ponto do espaço de busca nunca será zero, além de contornar o problema de mínimos locais, pois este mecanismo altera levemente a direção da busca. O operador de mutação é aplicado aos indivíduos com uma probabilidade dada pela taxa de mutação $\left(0.001 \leq P_{m} \leq 0.1\right)$; geralmente se utiliza uma taxa de mutação pequena, pois é um operador genético secundário. Uma baixa taxa de mutação previne que a busca fique estagnada em sub-regiões do espaço de busca. Além disso, possibilita que qualquer ponto do espaço de busca seja atingido. Com uma taxa muito alta a busca se torna essencialmente aleatória. Um exemplo de como ocorre a mutação é mostrado na Figura 3.1

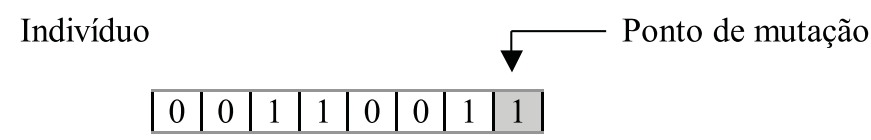

Indivíduo mutado

\begin{tabular}{|l|l|l|l|l|l|l|l|}
\hline 0 & 0 & 1 & 1 & 0 & 0 & 1 & 0 \\
\hline
\end{tabular}

Figura 3.1: Exemplo de mutação.

O cruzamento é o operador responsável pela recombinação de características dos pais durante o processo reprodutivo, permitindo que as próximas gerações herdem essas características. Ele é considerado o operador genético predominante, por isso é aplicado com probabilidade dada pela taxa de cruzamento $\left(0.6 \leq P_{c} \leq 0.99\right)$, sendo maior que a taxa de mutação. Quanto maior for essa taxa, mais rapidamente novas estruturas serão introduzidas na população. Mas se for muito alta, estruturas com boas aptidões poderão ser retiradas mais rapidamente que a capacidade da seleção em criar melhores estruturas. Se a taxa for muito baixa, a busca pode estagnar. 
Os operadores genéticos citados anteriormente, podem ser utilizados de várias maneiras. Os mais tradicionais são:

Cruzamento de Um-ponto: um ponto de cruzamento é escolhido. A partir deste ponto, as informações genéticas dos pais serão trocadas. As informações anteriores a este ponto em um dos pais são ligadas às informações posteriores a este ponto no outro pai, como mostrado na Figura 3.2.

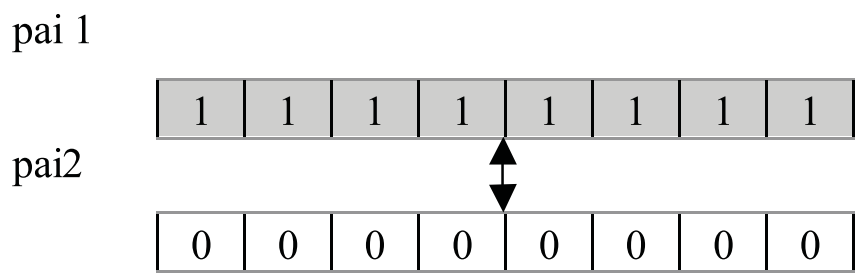

filho 1

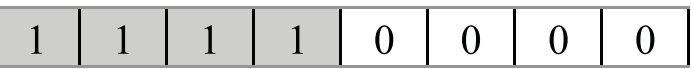

filho2

\begin{tabular}{|l|l|l|l|l|l|l|l|}
\hline 0 & 0 & 0 & 0 & 1 & 1 & 1 & 1 \\
\hline
\end{tabular}

Figura 3.2: Exemplo de cruzamento de um ponto.

Cruzamento de Dois-pontos ou Multipontos: no cruzamento de 2 pontos, ou multipontos, é realizada a troca de material genético através de mais de um ponto previamente definidos, como apresentado na Figura 3.3.

É uma generalização da idéia de troca de material genético através de pontos, em que vários pontos de cruzamento podem ser utilizados.

pai 1

pai 2

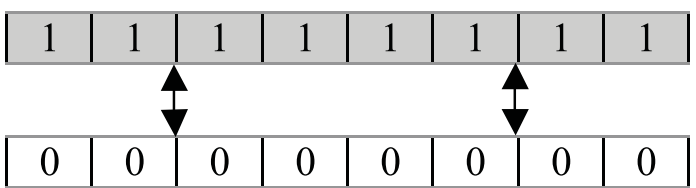

filho 1

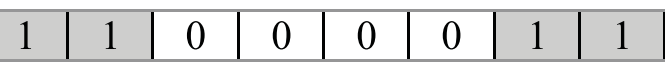

filho 2

\begin{tabular}{|l|l|l|l|l|l|l|l|}
\hline 0 & 0 & 1 & 1 & 1 & 1 & 0 & 0 \\
\hline
\end{tabular}

Figura 3.3: Exemplo de cruzamento de dois ponto. 
Cruzamento Uniforme: no cruzamento uniforme é gerado um indivíduo que é denominado como máscara de bits aleatórios.

Se o primeiro bit da máscara é 1 , então o primeiro bit do Pail é copiado para o primeiro bit do filho1, caso contrário o primeiro bit do pai2 é copiado. O processo se repete para os bits restantes do filho1.

Na geração do segundo filho, o processo é invertido. Se o valor na máscara é 1 , então será copiado o bit do pai2. Se o bit for 0 será copiado o bit do pai1, conforme apresentado na Figura 3.4.

O filho contém uma recombinação genética, ou seja, tem características dos dois pais.

O número de troca de pontos não é fixo, costuma-se utilizar a metade do comprimento do indivíduo, metade do número de genes, como a quantidade de pontos que serão trocados entres os pais na criação do indivíduo [BEASLEY et al. (1993)].

\section{Máscara}

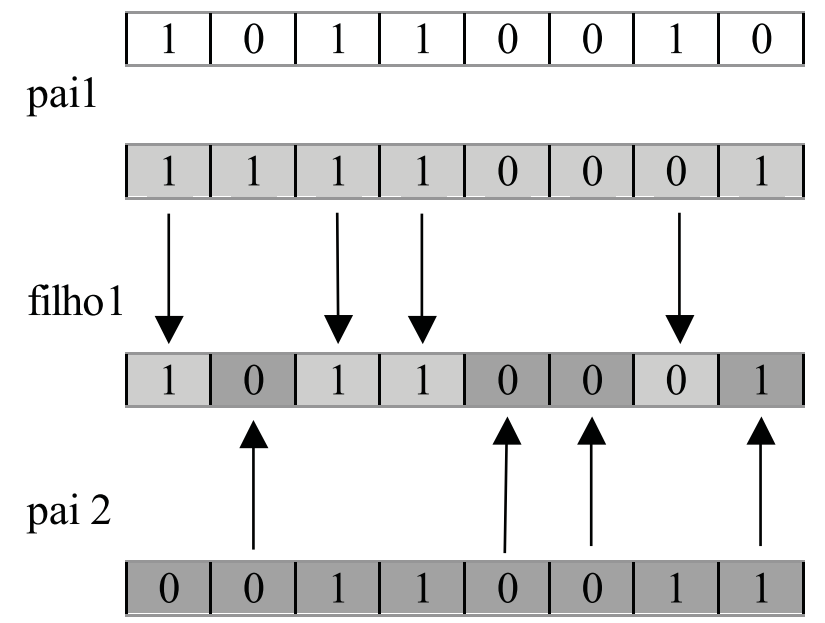

Figura 3.4: Exemplo de cruzamento uniforme.

O cruzamento, dentre todos os operadores genéticos, é o mais importante para a exploração rápida do espaço de busca. Quando aplicam-se os operadores genéticos toda a população será substituída por uma nova população, e isso ocorre a cada nova geração. Então, corre-se o risco de perder um indivíduo de alta aptidão podendo este não ser criado nas gerações sucessivas. Para que isto não ocorra, aplica-se o elitismo, 
como descrito a seguir.

Elitismo: o elitismo tem como função copiar os melhores indivíduos de uma geração para a próxima geração. Por exemplo, copiar os dois melhores indivíduos para a próxima geração, conforme demonstrado na Figura 3.5

\begin{tabular}{|c|c|c|c|c|c|c|c|}
\hline \multicolumn{8}{|c|}{ População } \\
\hline 0 & 0 & 1 & 1 & 0 & 0 & 1 & 1 \\
\hline 0 & 0 & 1 & 1 & 0 & 0 & 1 & 1 \\
\hline 0 & 0 & 1 & 1 & 0 & 0 & 1 & 1 \\
\hline & & xir & na & op & dlaç & & \\
\hline 0 & 0 & 1 & 1 & 0 & 0 & 1 & 1 \\
\hline 0 & 0 & 1 & 1 & 0 & 0 & 1 & 1 \\
\hline 1 & 0 & 0 & 1 & 0 & 0 & 1 & 1 \\
\hline
\end{tabular}

Figura 3.5: Exemplo de elitismo.

Para resolução do problema apontado houve a necessidade de uma modificação no algoritmo genético tradicional. Essa adaptação será mostrada no próximo capítulo. 


\section{Capítulo 4}

\section{Adaptação dos Algoritmos \\ Genéticos ao Planejamento da \\ Operação de Sistemas \\ Hidrotérmicos de Potência}

\subsection{Introdução}

Para o desenvolvimento e aplicação do algoritmo proposto para a solução do problema do Planejamento da Operação de Sistemas Hidrotérmicos de Potência foi necessária uma preparação e adaptação dos AGs às condições encontradas no problema do POSHP. Este foi o ponto básico da pesquisa realizada durante o mestrado, aperfeiçoada posteriormente, já que dela dependia o sucesso da proposta [LEITE (1999)].

Uma grande preocupação nesta preparação e adaptação foi a de respeitar as características físicas do problema original, tentando sempre observar a relação entre o real e o comportamento do algoritmo.

Atestada a possibilidade da aplicação de AGs, a continuidade da pesquisa, motivo do presente trabalho, foi a de aperfeiçoar a preparação e adaptação, aprofundar os estudos visando superar os obstáculos encontrados, tais como a dimensão dos indivíduos, aplicação da técnica a sistemas mais próximos da realidade, de grande porte, com 
grandes cascatas interligadas e com condições operativas mais severas, como também aperfeiçoar o desempenho do algoritmo com a introdução de novos recursos computacionais. A seguir serão apresentadas, no algoritmo proposto, todas as adaptações feitas no algoritmo tradicional para resolução do POSHP, e finalizando, será mostrado um Estudo, composto de três conjuntos de testes com o objetivo de verificar a viabilidade do algoritmo proposto.

\subsection{Algoritmo Proposto}

No intuito de tornar bem claro o uso dos AGs no problema em questão, optou-se por apresentar uma aplicação à uma usina real, partindo desde os dados básicos da usina, e das afluências, e desenvolvendo de forma detalhada as etapas do processo. Assim, apresenta-se a seguir o exemplo onde foi utilizada a usina hidroelétrica de Emborcação, pertencente ao Sistema Sudeste Brasileiro.

Nas Tabelas 4.1 e $4.2^{1}$ apresentam-se os dados da usina hidroelétrica de Emborcação utilizada na otimização.

Tabela 4.1: Dados da Usina hidroelétrica de Emborcação

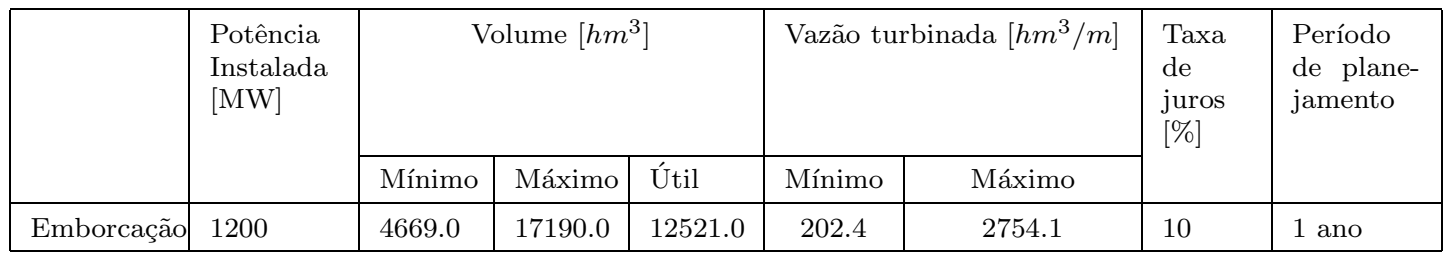

Tabela 4.2: Dados de demanda e afluência para resolução do problema proposto

\begin{tabular}{|l|l|l|l|l|l|l|l|l|l|l|l|l|}
\hline & Mai & Jun & Jul & Ago & Set & Out & Nov & Dez & Jan & Fev & Mar & Abr \\
\hline $\begin{array}{l}\text { Coeficiente } \\
\text { de demanda }\end{array}$ & 0.991 & 1.008 & 1.030 & 1.037 & 1.034 & 1.047 & 1.025 & 1.021 & 0.923 & 0.947 & 0.969 & 0.968 \\
\hline $\begin{array}{l}\text { Afluência } \\
\left(\mathrm{m}^{3} / \mathrm{s}\right)\end{array}$ & 407.0 & 311.0 & 246.0 & 191.0 & 162.0 & 208.0 & 359.0 & 647.0 & 888.0 & 917.0 & 855.0 & 634.0 \\
\hline
\end{tabular}

\footnotetext{
${ }^{1} \mathrm{O}$ coeficiente de demanda multiplicado pela potência instalada, definida no arquivo de entrada, fornecerá a carga a ser atendida em cada mês do período de planejamento
} 
Na Figura 4.1, observam-se os passo utilizados para determinar o volume ótimo da usina, nos 12 meses, através da aplicação de Algoritmos Genéticos.

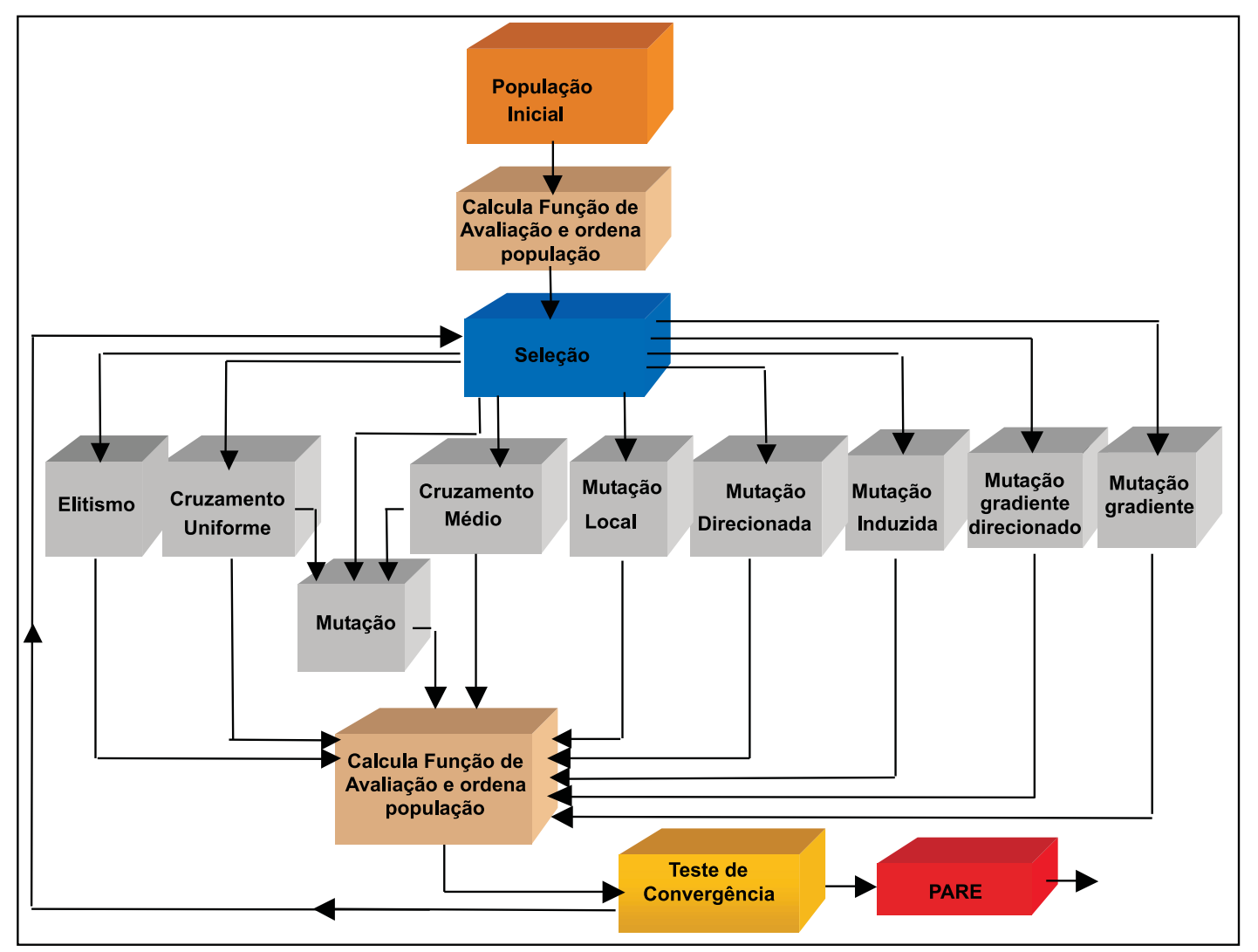

Figura 4.1: Algoritmo proposto

Durante o doutorado algumas etapas do diagrama apresentado na Figura 4.1 foram modificadas. Entre estas, a população inicial e o critério de seleção, bem como o acréscimo dos seguintes operadores genéticos: mutação local, mutação direcionada, mutação induzida, mutação gradiente direcionada e mutação gradiente.

Outra melhoria significativa diz respeito a adoção do gerador de números aleatórios mais eficiente [MATSUMOTO \& NISHIMURA (1998)], que resultou em um melhor desempenho do algoritmo proposto.

A seguir, apresenta-se a descrição do procedimento utilizado no algoritmo proposto.

Codificação do problema: a codificação do problema de Planejamento da Operação Energética precisa ser realizada com cuidado, já que este é um problema interligado no 
tempo, pois a decisão tomada em um determinado período afeta diretamente todos os outros. Essa etapa é considerada a mais importante, pois a viabilidade do algoritmo depende da sua codificação. Para uma melhor representação do problema, adotam-se valores reais e não binários, como é usual, e o indivíduo representará o volume da usina em cada mês do planejamento.

O Sistema Brasileiro é composto por várias usinas em cascata, como já mencionado anteriormente. Portanto, para representar o volume de todas as usinas em um único vetor, ter-se-ia uma cadeia de características muito longa. Por exemplo, para o planejamento de 2 anos (24 características) com 35 usinas, o individuo teria 840 genes. Sendo assim, optou-se por uma representação matricial tridimensional. Nesta matriz, no eixo $x$, estão representados os genes de um indivíduo de acordo com o período de planejamento, neste caso 12 mês, no eixo y, representam-se os indivíduos da população e no eixo $z$, está caracterizado o número de usinas envolvidas no sistema teste, conforme mostrado na Figura 4.2 .

Por exemplo, em um sistema teste com 3 usinas, 5 indivíduos e cada indivíduo com 12 características (genes) de acordo com o período de planejamento, a população ficaria configurada, conforme apresentada na Figura 4.2 .

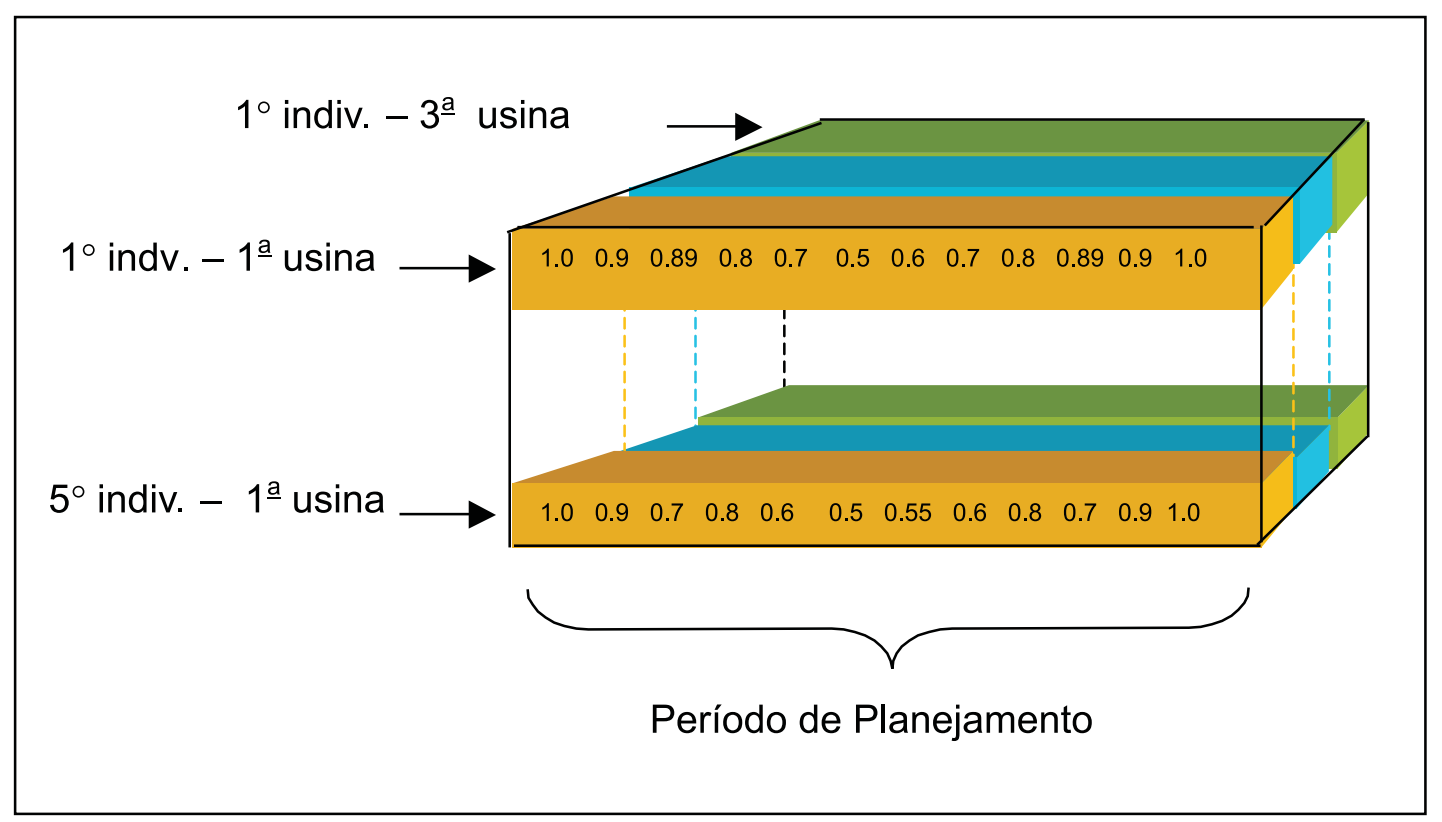

Figura 4.2: População.

O tamanho da população afeta diretamente o desempenho global e a eficiência dos 
AGs. Com uma população pequena, o desempenho pode cair, pois a população fornece uma pequena cobertura do espaço de busca do problema. Uma grande população geralmente fornece uma cobertura representativa do domínio do problema, além de prevenir convergências prematuras para soluções locais ao invés de globais. No entanto, para se trabalhar com grandes populações, são necessários maiores recursos computacionais, ou que o algoritmo trabalhe por um período de tempo muito maior, a fim de obter um resultado satisfatório [REZENDE (2003)].

Esta representação reflete a realidade dos reservatórios, nos quais o i-ésimo elemento de um indivíduo representa o i-ésimo volume útil, ou melhor dizendo, o volume operativo no período $i$ do planejamento, que é discretizado em meses.

Sabendo que:

Volume máximo operativo da $1^{\circ}$ usina $=17190.0$

Volume mínimo operativo da $1^{\circ}$ usina $=4669.0$

$\mathrm{VOL}=$ volume da $1^{\circ}$ usina, por unidade, em relação ao volume máximo operativo.

$V O L[\mathrm{i}][\mathrm{j}][\mathrm{k}]=$ volume do indivíduo $[\mathrm{i}]$, usina $[\mathrm{j}]$ e gene (mês) ou característica $[\mathrm{k}]$

$\operatorname{VOL}[1][1][1]=1.00$

$\operatorname{VOL}[1][1][2]=0.90$

Pode-se calcular o volume real que os genes 1 e 2 representam:

$$
\begin{aligned}
& V_{1}=V_{\text {mín }}+\left(V_{\text {máx }}-V_{\text {min }}\right) * V O L_{1} \\
& V_{1}=4669.0+(17190.0-4669.0) * 1.00 \\
& V_{1}=4660.0+(12521.0) * 1.00 \\
& V_{1}=17190.0
\end{aligned}
$$

Calculando o valor real do segundo gene têm-se:

$$
\begin{aligned}
& V_{2}=V_{\text {min }}+\left(V_{\text {máx }}-V_{\text {min }}\right) * V O L_{2} \\
& V_{2}=4669.0+(17190.0-4669.0) * 0.90 \\
& V_{2}=4660.0+(12521.0) * 0.90 \\
& V_{2}=15937.90
\end{aligned}
$$

Desta maneira, determina-se o volume real de todos os indivíduos da população. 
Após a codificação do problema, o próximo passo será a definição da população inicial.

Solução inicial: no inicio da pesquisa (Mestrado), utilizou-se apenas solução inicial aleatória, pois era preciso confirmar a viabilidade da técnica quando aplicada ao POSHP, sem que fosse fornecido ao algoritmo um conhecimento prévio do comportamento das usinas para um determinado período de planejamento [LEITE (1999)]. Confirmada a viabilidade da técnica e na tentativa de diminuir o tempo computacional exigido para convergência, optou-se por fornecer ao algoritmo informações já conhecidas através dos estudos do POSHP, realizados utilizando uma técnica tradicional de otimização [CARNEIRO \& BOND (1990)].

Após vários testes foram determinadas 5 formas de solução inicial. Na próxima seção esses testes serão mais detalhados para que se possa analisar melhor as investigações realizadas. Portanto, a população inicial poderá ser gerada adotando uma das soluções iniciais a seguir:

1. Aleatória: para cada indivíduo valores reais aleatórios entre 0 e 1 são gerados. Cada gene representa o volume em porcentagem para cada mês do período de planejamento.

2. Volume sugerido: nesse caso, o indivíduo pode ter os valores de suas características definidas pelo operador do sistema. Por exemplo, todos os genes iguais a 1.0, ou seja, $100 \%$ do volume útil. Neste caso, e em outros onde o volume permaneça constante durante todo o período de planejamento, justamente por não haver variação do volume, toda a água que chega na usina é turbinada ou vertida, caracterizando o que é chamado na literatura de solução a fio-d'água [CARNEIRO (1991)]. Normalmente, é utilizada quando se faz estudos com a ferramenta baseada em programação não-linear. Foi isso que motivou o uso dessa solução nos testes com AGs.

Adicionada essa possibilidade ao algoritmo, pode-se, variar as características dos genes com base no comportamento da usina operando em cascata, tendo eles valores iniciais iguais a $60 \%, 70 \%, 80 \%$, etc., do volume útil do reservatório. Acredita-se que essa informação poderá acelerar a convergência do algoritmo.

3. Volume sugerido + aleatória: seguindo a idéia apresentada no item 2, adota- 
se como solução inicial para as usinas de cabeceira características aleatórias, pois sabe-se, através de estudos, que seus volumes devem oscilar para atender as variações do mercado e das afluências. Nas demais usinas, os indivíduos terão características iguais a 100\%. Por exemplo, no caso de um sistema teste com três usinas, Emborcação, Itumbiara e São Simão, nas usinas 1 e 2 os genes iniciais serão aleatórios e na usina de São Simão iguais a 100\%. Através das sucessivas gerações essas características poderão mudar conforme a necessidade de atendimento do mercado e o período da afluência, ou seja, esse comportamento inicial será apenas um indicativo de operação ótima.

4. Solução inicial fornecida pelo algoritmo de otimização (PNL): sendo uma das propostas do projeto de doutorado a de se trabalhar com algoritmos híbridos, ou seja, os AGs em conjunto com outras técnicas de otimização, foi utilizado a saída fornecida pelo PNL como solução inicial dos AGs. Essa alternativa vem mostrando um bom desempenho, o que pode ser visto nos testes apresentados na próxima seção e no Capítulo 5.

5. PNL + 100\% (solução a fio-d'água): em uma população de 20 indivíduos o primeiro será fornecido pelo PNL e os demais terão características iguais a 100\%, ou seja, solução a fio-d'água.

Função de avaliação: ou função de custo, está relacionada à minimização ou maximização do valor esperado da função objetivo do problema.

No caso do planejamento da operação, a função de avaliação será o custo operativo no período de planejamento em conjunto com a adaptação do indivíduo, onde a cada restrição operativa do problema satisfeita, definidas na formulação matemática, é dado ao indivíduo um ponto. O mais pontuado será considerado mais apto. Sendo esta uma maneira de avaliar os membros do espaço de busca.

Outra opção para verificar a adaptação do indivíduo, seria a soma das falhas, onde considera-se a distância entre o valor da restrição operativa não atendida até o mínimo valor que esta restrição é aceita. Quanto menor for este somatório, mais apto será o indivíduo. 
Ordenação da população: o algoritmo proposto classifica a população calculando a função de avaliação de todos os indivíduos e depois ordenando-os conforme o objetivo do problema. No exemplo mencionado, o objetivo será o de minimizar o custo e atender as restrições operativas. Portanto, a população será ordenada do menor para o maior custo, sabendo que, o primeiro indivíduo terá o menor custo, desde que tenha atendido as restrições operativas.

Seleção: é feita a seleção para determinar em quais e em quantos indivíduos serão aplicados os diversos tipos de operadores genéticos utilizados, conforme Tabela 4.3.

Tabela 4.3: Dados utilizados na seleção da população.

\begin{tabular}{|l||c|l||c|}
\hline \multicolumn{2}{|c|}{ Tamanho da população } & \multicolumn{2}{c|}{24 indivíduos } \\
\hline Elitismo & 01 & Pontos de mutação & 10 \\
\hline Cruzamento uniforme & 06 & Mutação direcionada & 01 \\
\hline Cruzamento uniforme + mutação & 01 & Mutação induzida & 01 \\
\hline Cruzamento médio & 06 & Mutação local & 01 \\
\hline Cruzamento médio + mutação & 02 & Mutação grad. direcionada & 01 \\
\hline Taxa de seleção & 0.1 & Mutação gradiente & 01 \\
\hline Taxa de cruzamento & 0.1 & Taxa de Mutação & 0.1 \\
\hline Mutação & 03 & Chance de subida & 0.99 \\
\hline
\end{tabular}

Note que os dados contidos na Tabela 4.3 não são fixos. Estes foram utilizados para resolver o problema de uma usina. Cada problema exige uma determinação de parâmetros que podem ou não ser iguais a de um caso já determinado. Isso foi definido nos testes de ponderação dos operadores apresentados na próxima seção desse capítulo.

Observe que os valores de taxas de seleção, taxas de cruzamentos, taxas de mutações e quantos indivíduos sofrerão aplicação de cada tipo de operador genético, estão definidos em um arquivo de entrada, conforme Tabela 4.3. As taxas serão utilizadas para direcionar o sorteio, podendo privilegiar os indivíduos que ocupam as primeiras posições dentro da população.

O método de seleção mais simples e também mais conhecido é o Método da Roleta. Nele os indivíduos de um população, serão selecionados para formarem uma parte da próxima geração, utilizando o mesmo processo da roleta utilizada em jogos. Neste método cada indivíduo é representado na roleta por uma fatia proporcional ao seu índice 
de aptidão, para que, os indivíduos com maior aptidão tenham maiores possibilidades de serem escolhidos, ou seja uma área maior na roleta, o contrário ocorrendo com os menos aptos. Se roleta simples fosse baseada na posição do pai, seria definida da seguinte maneira:

Na roleta simples o ponto de corte é obtido da seguinte maneira:

Corte $=$ posição do pai 2 .

Sorteia-se um número $n$, entre 0 e posição do pai $1+$ posição do pai 2 .

$n=$ random (pai $1+$ pai 2$)$.

Se $n<$ corte, escolhe pai 1.

Senão, escolhe pai 2.

Utilizando a roleta simples, o grau que privilegia os indivíduos nas melhores posições é de taxa fixa. Dependendo do problema, haverá melhor resultado se existirem graus diferentes de privilégios. Portanto, o método de seleção adotado neste trabalho é o método da roleta ponderada, baseado na posição dos pais.

Então pode-se pensar, para pai 1 e pai 2, da seguinte maneira: atribui-se mais oportunidade a um ou ao outro indivíduo, dando às suas posições graus de privilégios diferentes. Adota-se um valor entre essas duas posições, que é calculado pela média ponderada pelos graus de privilégios. Então trabalha-se com uma roleta ponderada, a qual será mais flexível que a roleta simples.

Na roleta pela posição ponderada:

Corte $=$ taxa de seleção $*($ pai 1$)+(1-$ taxa de seleção $) *($ pai 2$)$

Se taxa de seleção $=0.8$, definida no arquivo de entrada no intervalo $\left[\begin{array}{ll}0 & \text { a }\end{array}\right]$.

Corte $=0.8+0.2 * 4=1.6$

Se taxa de seleção $=0.1$

Corte $=0.1+0.9 * 4=3.7$

Sorteia-se um número $n$ entre 0 e posição do (pai $1+$ pai 2 )

$n=\operatorname{random}($ pai $1+$ pai 2$)=5$

Se $n<$ corte, escolhe pai 1 , 
Senão, escolhe pai 2.

Ou seja, quanto menor a taxa de seleção, maior a chance de se escolher o melhor indivíduo. Pois com uma taxa de seleção $=0.1$, o valor de corte será igual a 3.7, como o valor $n$ sorteado está no intervalo [0 a 5$]$ a chance de sortear um número menor de 3.7 é grande.

\section{APLICAÇÃO DE OPERADORES GENÉTICOS}

A seguir serão apresentados os operadores genéticos utilizados nesse trabalho. Como mencionado anteriormente, alguns foram alterados e outros acrescentados para se adaptarem às condições do problema de POSHP.

Elitismo: para garantir que os melhores indivíduos não sejam perdidos de uma geração para a outra, aplica-se o elitismo. Isto garante que os melhores indivíduos passem para a próxima geração preservando suas características originais.

Cruzamento uniforme: quando aplica-se o cruzamento uniforme há a necessidade de se determinar de qual dos pais serão copiadas as características para criação do filho.

A maneira utilizada neste trabalho foi a seguinte: pode-se optar por três tipos de taxas de cruzamento diferentes, segundo a Tabela 4.4. Conforme a taxa adotada, utilizando uma função de ajuste [SCHLICK (1994)], o filho terá mais características do melhor pai. Para permitir que isso ocorra de forma bem aleatória, nada impede que o novo descendente tenha características dos dois pais na mesma proporção. Apenas é dado, através do sorteio, um peso maior aos melhores indivíduos, ou seja, os que estiverem nas primeiras posições poderão ser beneficiados.

Tabela 4.4: Tipos de taxas adotadas na seleção, cruzamento ou mutação.

\begin{tabular}{|c||l|}
\hline Valores das taxas & Probabilidade de sorteio \\
\hline taxa $<0.5$ & $\begin{array}{l}\text { aumenta a probabilidade de sortear os indivíduos nas } \\
\text { melhores posições. }\end{array}$ \\
\hline taxa $=0.5$ & $\begin{array}{l}\text { probabilidade de sortear os indivíduos de forma uni- } \\
\text { forme na população. }\end{array}$ \\
\hline taxa $>0.5$ & $\begin{array}{l}\text { aumenta a probabilidade de sortear os indivíduos nas } \\
\text { piores posições. }\end{array}$ \\
\hline
\end{tabular}

Vale lembrar que, quanto menor for a taxa adotada, maior será a chance de sele- 
cionar o melhor indivíduo, devido a função de ajuste [SCHLICK (1994)].

Exemplo:

Supondo que sejam sorteados dois indivíduos para sofrer cruzamento uniforme: pai 1 na posição 4 e pai 2 na posição 7 .

Cria-se um indivíduo chamado máscara onde o valor de cada gene será aleatório. Este valor será baseado no somatório das posições escolhidas para sofrerem cruzamento uniforme, conforme Figura 4.3.

Exemplo: pai 1, na posição 4; pai 2, na posição 7 e privilegiando o melhor indivíduo, adotando taxa $=0.1$.

\begin{tabular}{|c|c|c|c|c|c|c|c|c|c|c|c|}
\hline \multicolumn{12}{|c|}{ máscara } \\
\hline 3.0 & 9.0 & 2.0 & 1.0 & 5.0 & 8.0 & 0 & 10 & 7.0 & 12 & 4.0 & 11 \\
\hline \multicolumn{12}{|l|}{ pail } \\
\hline 1.00 & 0.92 & 0.85 & \begin{tabular}{|l|l}
0.74 \\
\end{tabular} & 0.60 & 0.50 & 0.50 & 0.60 & \begin{tabular}{|l}
0.74 \\
\end{tabular} & 0.85 & 0.92 & \begin{tabular}{|l|l}
1.00 \\
\end{tabular} \\
\hline \multicolumn{12}{|l|}{ Filho } \\
\hline 1.00 & 0.90 & 0.85 & 0.74 & 0.60 & 0.49 & 0.50 & 0.59 & 0.74 & 0.82 & 0.91 & 1.00 \\
\hline \multicolumn{12}{|l|}{ pai2 } \\
\hline 1.00 & 0.90 & 0.82 & 0.71 & 0.59 & 0.49 & 0.49 & 0.59 & 0.71 & 0.82 & 0.90 & 1.00 \\
\hline
\end{tabular}

Figura 4.3: Cruzamento uniforme proposto.

onde:

$$
\begin{aligned}
& \sum_{\text {posicões }}=\text { pai } 1+\text { pai } 2+2 \\
& \sum_{\text {posicões }}=4+7+2 \\
& \sum_{\text {posicões }}=13
\end{aligned}
$$

Portanto, o sorteio será no intervalo de 0 a 13.

Baseado na taxa de cruzamento adotada, calcula-se o valor de $\alpha$, ou seja o corte, que será utilizado para comparar com cada gene da máscara. Se o gene tiver valor menor que $\alpha$ copia-se característica do pai1, caso contrário copia-se característica do pai 2, conforme Figura 4.3.

Cálculo da variável $\alpha$ (corte):

privilegiar o melhor $\Rightarrow \operatorname{tax} a=0.1$

$$
\alpha=\operatorname{taxa} *(\text { pai } 1+1)+(1-\text { taxa }) *(\text { pai } 2+1)
$$




$$
\begin{aligned}
& \alpha=0.1 *(4+1)+(1-0.1) *(7+1) \\
& \alpha=0.1 * 5+0.9 * 8 \\
& \alpha=0.5+7.2 \\
& \alpha=7.7 \\
& \text { indiferente } \Rightarrow \text { taxa }=0.5 \\
& \alpha=\text { taxa } *(\text { pai } 1+1)+(1-\text { taxa }) *(\text { pai } 2+1) \\
& \alpha=0.5 *(4+1)+(1-0.5) *(7+1) \\
& \alpha=0.5 * 5+0.5 * 8 \\
& \alpha=2.5+4.0 \\
& \alpha=6.5 \\
& \text { privilegiar o pior } \Rightarrow \text { taxa }=0.9 \\
& \alpha=\text { taxa } *(\text { pai } 1+1)+(1-\text { taxa }) *(\text { pai } 2+1) \\
& \alpha=0.9 *(4+1)+(1-0.9) *(7+1) \\
& \alpha=0.9 * 5+0.1 * 8 \\
& \alpha=4.5+0.8 \\
& \alpha=5.3
\end{aligned}
$$

Pode-se observar no exemplo, que utilizando uma taxa pequena, taxa $=0.1$, o indivíduo recebeu mais características do pai 1, como mostrado na Figura 4.3, pois o valor do corte é igual 7.7, ou seja o intervalo de sorteio que beneficia o melhor pai é maior. Mas pode acontecer, como já citado anteriormente, que o indivíduo tenha a mesma proporção, quando a taxa for igual a 0.5 , ou até mais características do pai 2 , quando a taxa adotada for maior que 0.5 , pois trata-se de um algoritmo aleatório.

Cruzamento médio: a idéia de se aplicar um cruzamento baseado na média surgiu com o objetivo de obter um indivíduo que tivesse características dos dois pais e não apenas de um.

Por exemplo, no caso de cruzamento racial, entre um branco e um negro, o descendente deste cruzamento poderá ser um branco, um negro ou um mulato. Em outras 
palavras, o descendente poderá se situar em qualquer posição entre os extremos, não havendo uma raça ou característica contínuas, em que não há interrupção, o filho poderá ter qualquer característica entre os dois valores dos pais.

Logo, no caso em que utiliza-se gene real, codificando características contínua como um gene, o cruzamento onde o filho herda característica intermediária dos pais, será bem sucedido.

Quando aplica-se o cruzamento médio há a necessidade de se determinar o valor obtido da soma das características (genes) do casal escolhido para criar um descendente, como já exposto acima. Pode-se aplicar a média ponderada entre as características dos dois pais.

Portanto, este trabalho propõe uma maneira de calcular a média de forma a beneficiar os indivíduos que ocupam as melhores posições, ou seja, a melhor característica de um indivíduo pode estar próxima a um valor do melhor pai.

Como no cruzamento uniforme, pode-se optar por tipos de taxas de cruzamento diferentes. Conforme a taxa adotada, tem-se uma distribuição [SCHLICK (1994)], que proporciona ao filho obter características próximas do melhor indivíduo. Esse tipo de distribuição, tanto no cruzamento uniforme como no cruzamento médio, dá maiores chances aos indivíduos nas primeiras posições de serem sorteados, que no nosso caso são os melhores, semelhante ao método da roleta.

Exemplo:

Supondo que sejam sorteados dois indivíduos para sofrerem cruzamento médio, pai 1 na posição 19 e pai 2 na posição 22.

$\mathrm{O}_{\text {gene }}{ }_{\text {novo }}$ do filho será obtido através da média ponderada entre as características do dois pais da seguinte forma: gene $_{\text {novo }}=T *$ gene $_{\text {pai } 1}+(1-T) *$ gene $_{\text {pai } 2}$.

onde: $T$ será calculado pela seguinte função: $T=\operatorname{BiasRand}(a)$.

BiasRand $(\mathrm{a})=$ será devolvido um valor para $T$ entre 0 e 1 segundo o valor de "a ". Se o valor de "a " for menor que 0.5 , a probabilidade de se sortear um número próximo de zero é maior. Se for igual a 0.5 , a probabilidade de sortear um número entre 0 e 1 é uniforme. Finalmente, se o valor for maior que 0.5, a probabilidade de sortear um valor próximo de 1 é maior. 
Diante da necessidade de obter um valor para "a " que pudesse ser usado como uma taxa, ou seja $\in[0,1]$, calcula-se o valor de "a " através da média ponderada entre as posições que os pais ocupam na população, pai1+1 e pai2+1, dividida pelo somatório dessas duas posições. Assim, pretende-se relacionar a participação do gene de acordo com a sua chance na roleta, tomando "a " como a probabilidade de ser sorteado na roleta ponderada:

Calcule:

privilegiar o melhor $\Rightarrow \operatorname{tax} a=0.1$

$$
\begin{aligned}
& a=(\text { taxa } *(\text { pai } 1+1)+(1-\text { taxa }) *(\text { pai } 2+1)) /(\text { pai } 1+\text { pai } 2+2) \\
& a=(0.1 *(19+1)+(1-0.1) *(22+1)) /(19+22+2) \\
& a=(2+((0.9 * 23)) / 43 \\
& a=(2+20.7) / 43 \\
& a=0.53
\end{aligned}
$$

indiferente $\Rightarrow \operatorname{tax} a=0.5$

$$
\begin{aligned}
& a=(\text { taxa } *(\text { pai } 1+1)+(1-\text { taxa }) *(\text { pai } 2+1)) /(\text { pai } 1+\text { pai } 2+2) \\
& a=(0.5 *(19+1)+(1-0.5) *(22+1)) /(19+22+2) \\
& a=(10+((0.5 * 23)) / 43 \\
& a=(10+11.5) / 43 \\
& a=0.5
\end{aligned}
$$

privilegiar o pior $\Rightarrow \operatorname{tax} a=0.9$

$$
\begin{aligned}
& a=(\text { taxa } *(\text { pai } 1+1)+(1-\text { taxa }) *(\text { pai } 2+1)) /(\text { pai } 1+\text { pai } 2+2) \\
& a=(0.9 *(19+1)+(1-0.9) *(22+1)) /(19+22+2) \\
& a=(18+((0.1 * 23)) / 43 \\
& a=(18+23) / 43 \\
& a=0.47
\end{aligned}
$$

De acordo com a taxa que privilegia o melhor indivíduo e os valores de $a$ e $T$, pode-se obter o novo valor do gene 1, conforme Figura 4.4, da seguinte maneira: 
Para $\mathrm{a}=0.57$ e $\mathrm{T}=\mathbf{0 . 8}$

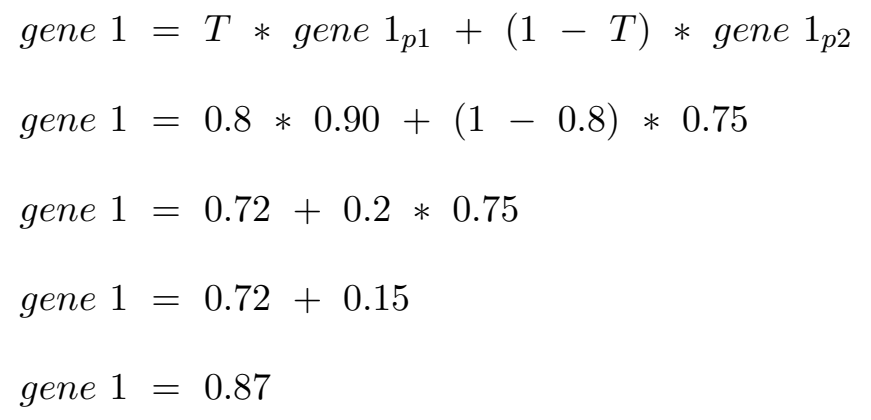

Caso fossem adotadas taxa $=0.5$ ou taxa que privilegie o pior indivíduo, o valor do gene 1 seria:

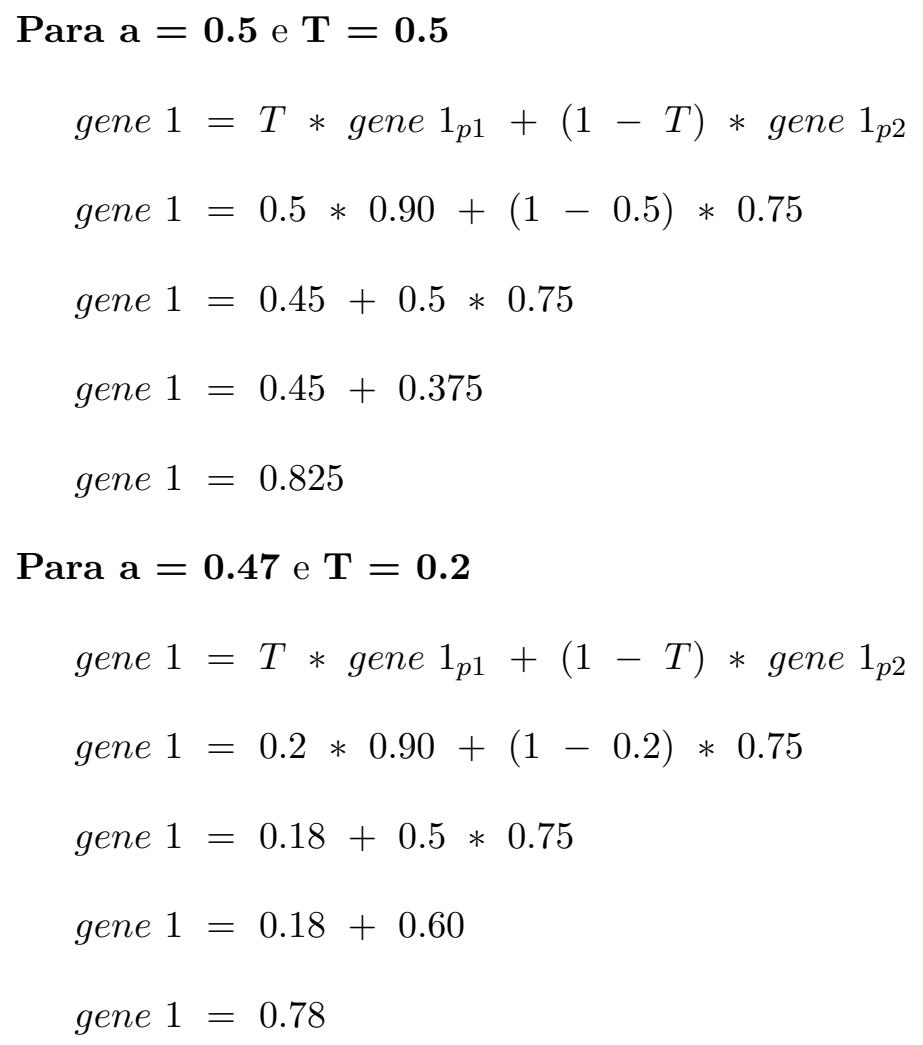

Figura 4.4: Cruzamento médio proposto. 
Mutação: com o objetivo de manter a diversidade da população, o operador genético de mutação será aplicado em alguns descendentes criados através de cruzamento uniforme, cruzamento médio e em alguns que não sofreram nenhum tipo de cruzamento.

Trabalhando com características contínuas, há a necessidade de uma adaptação do operador de mutação. O binário muda de 0 para 1 ou vice-versa. No problema proposto, isso não será viável. Portanto, adota-se uma maneira de mutar os indivíduos de uma forma não brusca, ou seja, não é coerente mudar o volume do reservatório de $90 \%$ para $45 \%$. Porém, pode-se pensar em uma maneira de conseguir que o novo valor do gene mutado esteja próximo do gene original.

Primeiramente, o número de pontos de mutação será considerado como sendo um dado de entrada, conforme Tabela 4.3. Entretanto, quando da aplicação deste operador genético, é feito um sorteio no intervalo de 0 (zero) ao número de pontos de mutação determinado, ou seja, não necessariamente será modificada a quantidade de pontos pré-determinados.

Após sorteada a quantidade de pontos que serão modificados, faz-se uma lista com cada posição sorteada para sofrer mutação, evitando que um mesmo ponto seja escolhido mais de uma vez.

Exemplo:

Supondo que o indivíduo na $25^{a}$ colocação foi escolhido para sofrer mutação.

Determina-se, por sorteio, a quantos pontos de um indivíduo será aplicada a mutação. Supondo que o número de pontos determinados é igual a 5 , conforme mostrado na Figura 4.5, faz-se:

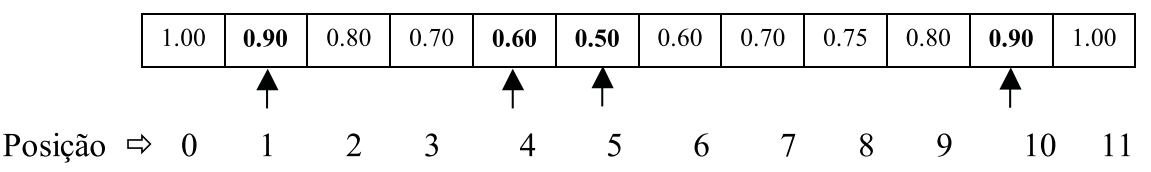

Figura 4.5: Mutação proposta.

1. Sortear um número que está no intervalo de $\left[\begin{array}{lll}0 & \text { a } & 5\end{array}\right]$. Supondo que o número sorteado seja igual a 4 ; 
2. Montar uma lista com pontos a serem mutados. Sabendo que esta lista deverá conter a informação das posições dos genes a serem alteradas.

- Sorteia-se qualquer posição do indivíduo: A posição 1 foi sorteada. Esta posição não entra mais no sorteio das próximas posições

- Sorteia-se qualquer posição do indivíduo: A posição 4 foi sorteada. Esta posição corresponde à posição 5 no indivíduo, pois a posição sorteada não conta mais.

- Sorteia-se qualquer posição do indivíduo: A posição 3 foi sorteada. Esta posição corresponde à posição 4 no indivíduo.

- Sorteia-se qualquer posição do indivíduo: A posição 7 foi sorteada. Esta posição corresponde à posição 10 no indivíduo.

3. Obter os valores novos para cada posição sorteada.

- Para a primeira posição sorteia-se um valor próximo do valor original 0.9, com uma taxa de 0.1. Com esta taxa de mutação o valor sorteado pode ser qualquer número próximo do valor original do gene, segundo a função Gain [SCHLICK (1994)], exemplificada a seguir. Aplicada a função, o valor do novo gene passa a ser 0.92 . Repete-se o procedimento para as demais posições, usando: gene $_{\text {novo }}=C$ GainRand $($ gene, taxa $)$

onde:

CGainRand $(()$, taxa $)=$ será devolvido um valor para gene $_{\text {novo }}$ entre 0 e 1 segundo a taxa escolhida. Se o valor da taxa for menor que 0.5, a probabilidade de se sortear um número próximo do valor do gene escolhido para ser mutado é maior. Se for igual a 0.5 , a probabilidade é igual para um valor entre 0 e 1 . Finalmente se o valor for maior que 0.5 , a probabilidade de sortear um valor próximo do valor do gene escolhido para ser mutado é pequena.

Portanto:

- Para a posição 4 o novo valor será de 0.65 .

- Para a posição 5 o novo valor será de 0.49 .

- Para a posição 9 o novo valor será de 0.88 . 


\begin{tabular}{|l|l|l|l|l|l|l|l|l|l|l|l|}
\hline 1.00 & $\mathbf{0 . 9 2}$ & 0.80 & 0.70 & $\mathbf{0 . 6 5}$ & $\mathbf{0 . 4 9}$ & 0.60 & 0.70 & 0.75 & 0.80 & $\mathbf{0 . 8 8}$ & 1.00 \\
\hline
\end{tabular}

Figura 4.6: Novo indivíduo após mutação proposta

4. Finalmente, têm-se o novo indivíduo, apresentado na Figura 4.6.

Mutação direcionada: como se trata de um problema onde, quanto mais uniforme for a geração térmica menor será o custo da operação, faz-se um rastreamento de todos os valores de maior e menor geração (picos) ocorridos durante o período de planejamento e aplica-se mutação nestes pontos, de forma a manter o valor de geração o mais uniforme possível.

Mutação induzida: através de vários estudos é suposto que se conhece o comportamento ótimo esperado das usinas em cascata, quando em condições ideais. Como as usinas ocupam posições diferentes no conjunto, as características de operação são diferenciadas. As usinas à montante assumem a função de regularização do sistema, o que significa que oscilam no volume de seus reservatórios, enquanto as usinas à jusante mantêm os seus reservatórios cheios durante o período de planejamento. Baseado na operação ótima de reservatórios, estudada pela técnica tradicional de otimização, o operador de mutação induzida daria maiores chances aos genes correspondentes às usinas à montante de variarem os seus volumes, enquanto os genes correspondentes às usinas a jusante permaneceriam inalterados, ou seja, com $100 \%$ do volume útil, o que reduziria o tempo computacional, pois fazem com que as usinas à reservatório de fim de cascata tenham características de operação a fio-d'água, ou seja, não esvaziem seus reservatórios.

Mutação local: como a aplicação foi feita em um problema complexo e de grande porte, para evitar que o algoritmo demore a convergir, a partir do momento em que se tem um indivíduo que atenda a todas as restrições é feita uma verificação a cada $n$ iterações, pré-definida pelo operador do sistema. Nesta etapa, para os indivíduos com os mesmos valores de genes, isto é, indivíduos idênticos, somente um é mantido 
na população, enquanto os outros sofrerão alterações nas suas características com objetivo de explorar a vizinhança, ou seja, obter um outro indivíduo com características próximas do que foi descartado e que possa se aproximar da solução ótima, conforme mostrado na Figura 4.7. Essas alterações, seguem os mesmos mecanismos utilizados na mutação, respeitando uma taxa pré-determinada pelo operador, só que, neste caso, todas as características serão alteradas.

\begin{tabular}{|c|c|c|c|c|c|c|c|c|c|c|c|}
\hline \multicolumn{12}{|c|}{ Indivíduo antes de aplicar busca local } \\
\hline 1.0 & 0.91 & 0.87 & 0.75 & 0.63 & 0.55 & 0.56 & 0.63 & 0.75 & 0.87 & 0.91 & 1.0 \\
\hline \multicolumn{12}{|c|}{ Depois da busca local } \\
\hline 1.0 & 0.90 & 0.85 & 0.74 & 0.65 & 0.56 & 0.57 & 0.65 & 0.74 & 0.85 & 0.90 & 1.0 \\
\hline
\end{tabular}

Figura 4.7: Mutação local proposta.

A literatura internacional tem mostrado a importância e o sucesso dos algoritmos híbridos, onde uma técnica tradicional de otimização trabalha em conjunto com os AGs [GEN \& CHENG (1989) e DAVID CORNE \& GLOVER (1999)]. Portanto, optou-se por implementar o método do gradiente [SALOMON (1998) e BAZARAA \& SHETTY (1979)], dando origem a dois operadores genéticos de mutação, que foram definidos como mutação gradiente e mutação gradiente direcionada. Esse serão descritos abaixo.

Mutação gradiente: para melhor compreensão dos dois operadores genéticos baseados no método do gradiente, será mostrado brevemente a forma de calculá-lo para uma função $f(x)$.

O gradiente, ou velocidade de variação, de $f(x)$ em um ponto $x$, pode ser aproximado por $\Delta f / \Delta x$. Pode-se escrevê-lo exatamente como:

$$
\frac{\partial f(x)}{\partial x}=\lim _{\Delta x \rightarrow 0} \frac{f(x+\Delta x)-f(x)}{\Delta x}
$$

o qual é conhecido como a derivada parcial de $f(x)$ em relação a $x$.

Suponha que se deseja minimizar a função $f(x)$ e efetuar uma variação em $x$ para minimizar $f(x)$. Precisa-se para isso conhecer a derivada de $f(x)$. Há três casos a 
considerar:

- Se $\partial f / \partial x>0$, então $f(x)$ aumenta quando $x$ aumenta, por isso se deve diminuir $x$.

- Se $\partial f / \partial x<0$, então $f(x)$ diminui quando $x$ aumenta, por isso se deve aumentar $x$.

- Se $\partial f / \partial x=0$, então $f(x)$ é um máximo ou um mínimo, ou seja um ponto de inflexão ou ponto de cela, por isso não se deve variar $x$.

Portanto,

$$
x(k)=x(k-1)-\eta \frac{\partial f}{\partial x}
$$

em que $\eta$ é uma constante positiva, pequena, que especifica quanto se deve variar $x$ (na iteração $k$ ) e a derivada $\partial f / \partial x$ indica a direção dessa variação. Se, repetidamente, esta equação for usada, $f(x)$ continuará a descer em relação ao seu valor mínimo (desde que $\eta$ seja suficientemente pequeno).

No caso do problema do POSHP, escolhe-se um indivíduo da população, alguns pontos (gene) são sorteados aleatoriamente, e calcula-se o gradiente nestes pontos visando a minimização da função objetivo.

Por exemplo: o indivíduo $i$ foi sorteado na população e nos pontos 2,7 e 10 será calculado o gradiente.

Calculando o custo, conforme definido na formulação matemática, para o indivíduo $i$, tem-se:

custo $(i)=550219.3222$, custo do indivíduo antes da aplicação da mutação gradiente.

A seguir acrescenta-se um valor $\Delta x=0.00001$ em cada ponto escolhido e calcula-se novamente o custo do indivíduo $i$.

$$
\begin{aligned}
& \operatorname{custo}\left(x_{2}\right)=550217.7717, \text { quando } x_{2}=0.96651 ; \\
& \operatorname{custo}\left(x_{7}\right)=550216.9448, \text { quando } x_{7}=0.73541 ; \\
& \operatorname{custo}\left(x_{10}\right)=550221.1841, \text { quando } x_{10}=0.91181 ;
\end{aligned}
$$


O próximo passo consiste em calcular a derivada de $f(x)$ em cada ponto:

$$
\begin{aligned}
& \frac{\partial f(x)}{\partial x}=\frac{f(x+\Delta x)-f(x)}{\Delta x} \\
& \frac{\partial f(x)}{\partial x_{2}}=\frac{f\left(x_{2}+\Delta x\right)-f(x)}{\Delta x}=\frac{\text { custo }\left(i_{2}\right)-\text { custo }(i)}{0.00001}=-155048.653 \\
& \frac{\partial f(x)}{\partial x_{7}}=\frac{f\left(x_{7}+\Delta x\right)-f(x)}{\Delta x}=\frac{\text { custo }\left(i_{7}\right)-\text { custo }(i)}{0.00001}=-237734.2003 \\
& \frac{\partial f(x)}{\partial x_{1} 0}=\frac{f\left(x_{1} 0+\Delta x\right)-f(x)}{\Delta x}=\frac{\text { custo }\left(i_{10}\right)-\text { custo }(i)}{0.00001}=186190.9283
\end{aligned}
$$

Conforme mencionado anteriormente, $\eta$ tem que ser pequeno. Então $\eta$ será obtido através de um número sorteado dividido por $\alpha$. Sendo, $\alpha$ dado pela normalização da derivada da função $f$ em relação aos pontos escolhidos para aplicação do operador. Portanto:

Normalizando,

$$
\begin{aligned}
& \alpha^{2}=\left(\frac{\delta f}{\delta x_{2}}, \frac{\delta f}{\delta x_{7}}, \frac{\delta f}{\delta x_{1} 0}\right)= \\
& (-155048.653,-237734.2003,186190.9283)= \\
& \sqrt{(-155048.653)^{2}+(-237734.2003)^{2}+(+186190.9283)^{2}}=339447.6345
\end{aligned}
$$

Calculando $\eta$ : onde um número sorteado pseudo-aleatoriamente $\in[0,1]$ é dividido por $\alpha^{2}$.

$$
\begin{aligned}
& \eta_{2}=\frac{\text { número sorteado }}{\alpha}=\frac{0.00051}{339447.6345}=1.50244 E-09 \\
& \eta_{7}=\frac{\text { número sorteado }}{\alpha}=\frac{0.00071}{339447.6345}=2.09163 E-09 \\
& \eta_{10}=\frac{\text { número sorteado }}{\alpha}=\frac{0.00031}{339447.6345}=9.13248 E-10
\end{aligned}
$$

finalizando, tem-se os novos valores para $x_{2}, x_{7}$ e $x_{10}$.

$$
\begin{aligned}
& x_{i_{\text {novo }}}=x_{i}-\eta_{i} \frac{\partial f}{\partial x_{i}} \\
& x_{2 \text { novo }}=0.9665-\eta_{2} \frac{\partial f}{\partial x_{2}}=0.9667 \\
& x_{7 \text { novo }}=0.7354-\eta_{7} \frac{\partial f}{\partial x_{7}}=0.7359 \\
& x_{10 \text { novo }}=0.9118-\eta_{1} 0 \frac{\partial f}{\partial x_{10}}=0.9116
\end{aligned}
$$

Portanto, o custo $\left(i_{\text {novo }}\right)=550037.1841$, ou seja a função foi minimizada, e as novas características do indivíduo $i$ são apresentadas na Figura 4.8 . 


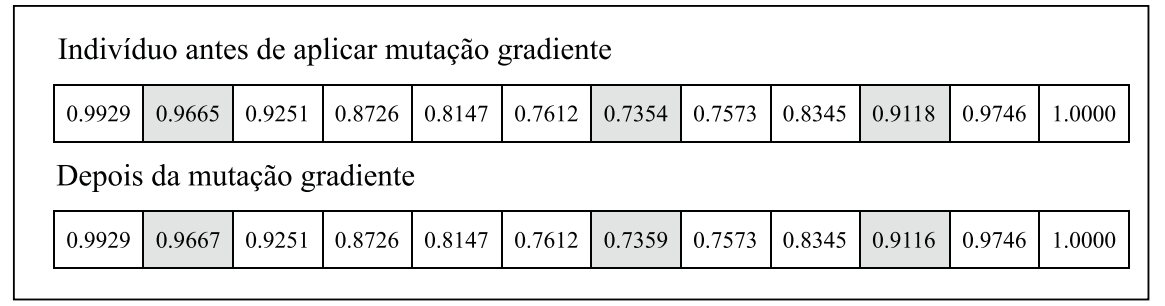

Figura 4.8: Mutação gradiente.

Mutação gradiente direcionada: aproveitando a idéia da mutação direcionada, onde os picos de geração térmicas são identificados, escolhem-se alguns picos e nestes pontos calcula-se o gradiente com objetivo de encontrar o menor custo da função objetivo, adotando-se o mesmo procedimento da mutação gradiente.

No intuito de analisar o uso do algoritmo proposto no problema em questão, optouse por apresentar na próxima seção um Estudo, com três conjuntos de testes distintos.

\subsection{Estudo}

Neste Estudo, o algoritmo proposto foi aplicado em sistemas testes compostos de 1, 3, e 7 usinas hidroelétricas pertencentes ao Sistema Sudeste Brasileiro. Foram utilizadas as usinas de Emborcação, Itumbiara e São Simão, localizadas no rio Paranaíba, as usinas de Furnas, Marimbondo e Água Vermelha, localizadas no rio Grande e a usina de Ilha Solteira, localizada no rio Paraná, conforme Figura 4.9.

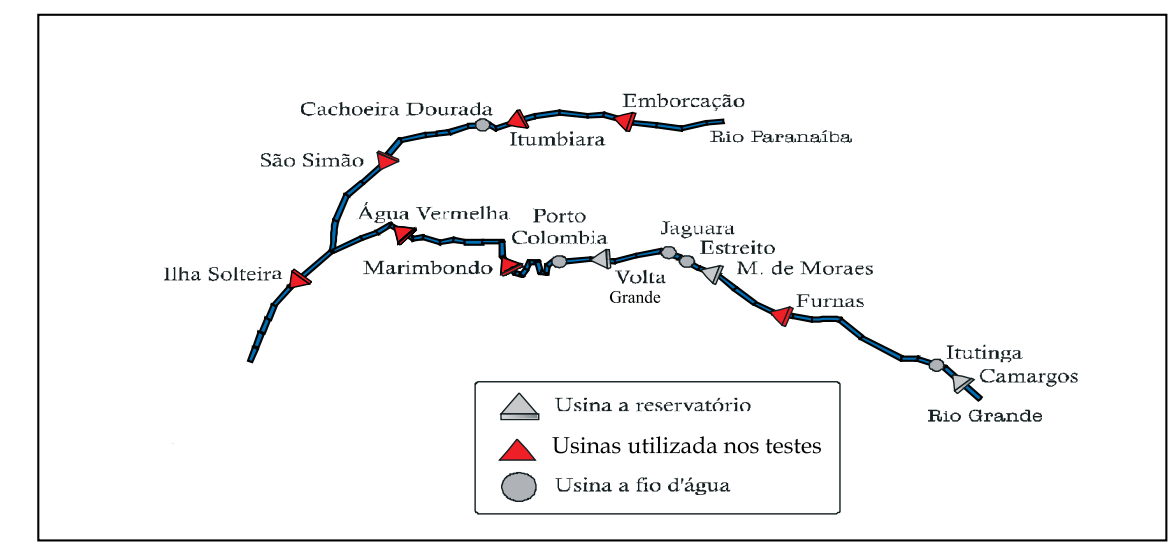

Figura 4.9: Parte do Sistema Sudeste Brasileiro utilizado no Estudo 
Os principais dados das usinas escolhidas para esse Estudo, tais como: volumes, vazões turbinadas e as potências efetivas são apresentadas no Apêndice B.

Para os testes com 1 e 3 usinas, foram utilizadas vazões afluentes iguais a $80 \%$ da Média de Longo Termo (MLT), e para o teste com 7 usinas foram utilizadas vazões iguais a MLT, com volumes inicial e final em 100\% do volume útil, um horizonte de planejamento de 24 meses, com demanda variando sazonalmente ao longo de cada ano e a configuração da população utilizada nos AGs é a mesma apresentada na Tabela 4.3.

Os testes foram divididos nos seguintes grupos:

1. Grupo 1: operação das usinas hidroelétricas no período de planejamento, determinado pela técnica de otimização tradicional (PNL). Considera-se como solução inicial a operação a fio d'água das usinas, ou seja, os valores de volume de cada usina são igualados a $100 \%$ do respectivo volume útil do reservatório.

2. Grupo 2: operação das usinas hidroelétricas no período de planejamento, determinado pelos Algoritmos Genéticos (AGs). Solução inicial aleatória, ou seja, os valores de volume de cada usina variam entre $0 \%$ a $100 \%$ do respectivo volume útil do reservatório.

3. Grupo 3: operação das usinas hidroelétricas no período de planejamento, determinado pelos Algoritmos Genéticos (AGs). Solução inicial a fio d'água.

4. Grupo 4: operação das usinas hidroelétricas no período de planejamento, determinado pelos Algoritmos Genéticos (AGs). Solução inicial dada pelo PNL.

Na Tabela 4.5, são apresentados os custos de operação para os 3 testes e 4 grupos. As legendas PNL, AGs(aleatório), AGs(100\%) e PNL+AGs, referem-se aos resultados encontrados pela técnica de Programação Não-Linear baseada em fluxo em rede [CARNEIRO \& BOND (1990)], Algoritmos Genéticos com população inicial aleatória, Algoritmo Genético com população inicial igual 100\% do volume útil, Algoritmos Genéticos com a população inicial definida através de PNL, respectivamente. Os resultados representam a média entre três simulações e número de fixo de gerações.

De acordo com os resultados expostos na Tabela 4.5, pode-se observar que quando foram realizados os testes onde os AGs tiveram sua solução inicial igual 100\%(AGs(100\%)), 
Tabela 4.5: Estudo - Custo de Operação

\begin{tabular}{|l||l||l||l|}
\hline Grupos & 1 usina & 3 usinas & 7 usinas \\
\hline 1 - PNL & 918652.00 & 21466754.00 & 22087999.00 \\
\hline 2 - AGs (aleatório) & 918480.03 & 22094935.74 & 22819030.58 \\
\hline 3 - AGs (100\%) & 918479.91 & 21727512.96 & 22041301.44 \\
\hline 4 - PNL + AGs & 918480.01 & 21727519.07 & 22027457.09 \\
\hline
\end{tabular}

no caso de 1 usina e PNL+AGS, para 7 usinas, obtiveram-se os menores custos de operação. Já no caso de 3 usinas, os AGs não superaram o PNL.

Para esse Estudo, optou-se por apresentar as trajetórias ótimas de volume do sistema composto por 7 usinas, por ser mais complexo.

As curvas de volumes definidas por PNL, são apresentadas na Figura 4.10 e PNL+AGs são apresentadas na Figura 4.11. Observe a semelhança nas trajetórias definidas pelos testes. Baseado na semelhança das técnicas pode-se dizer que os AGs captam sem dificuldades as características de operação das usinas, definindo um cronograma de operação ótimo no período de planejamento.

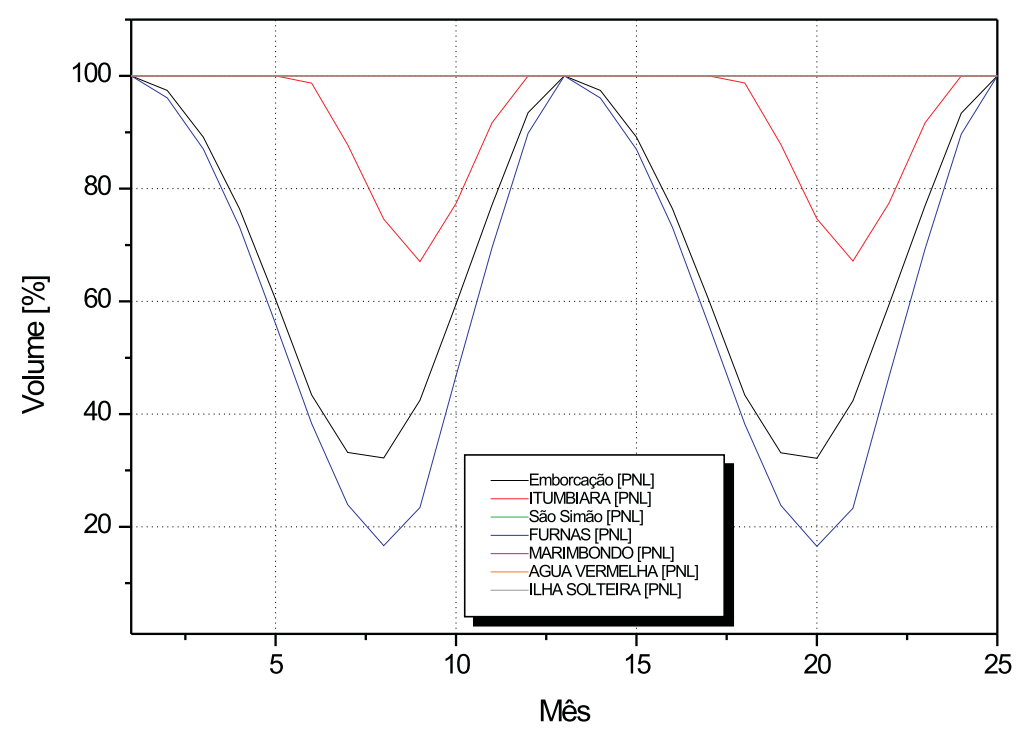

Figura 4.10: Estudo - Trajetória ótima de volume para as 7 usinas (PNL)

Observe nas Figuras 4.10 e 4.11, que as usinas hidroelétricas de Emborcação, Itumbiara e Furnas, a montante, se encarregam da regulação do sistema, oscilando seus volumes de forma cíclica e atingido os volumes máximos a cada final do período 
cheio, enquanto as usinas hidroelétricas de São Simão, Marimbondo, Água Vermelha e Ilha Solteira, a jusante, trabalham como usinas a fio-d'água, ou seja, não permitem variações no seus volumes, turbinando toda a vazão afluente.

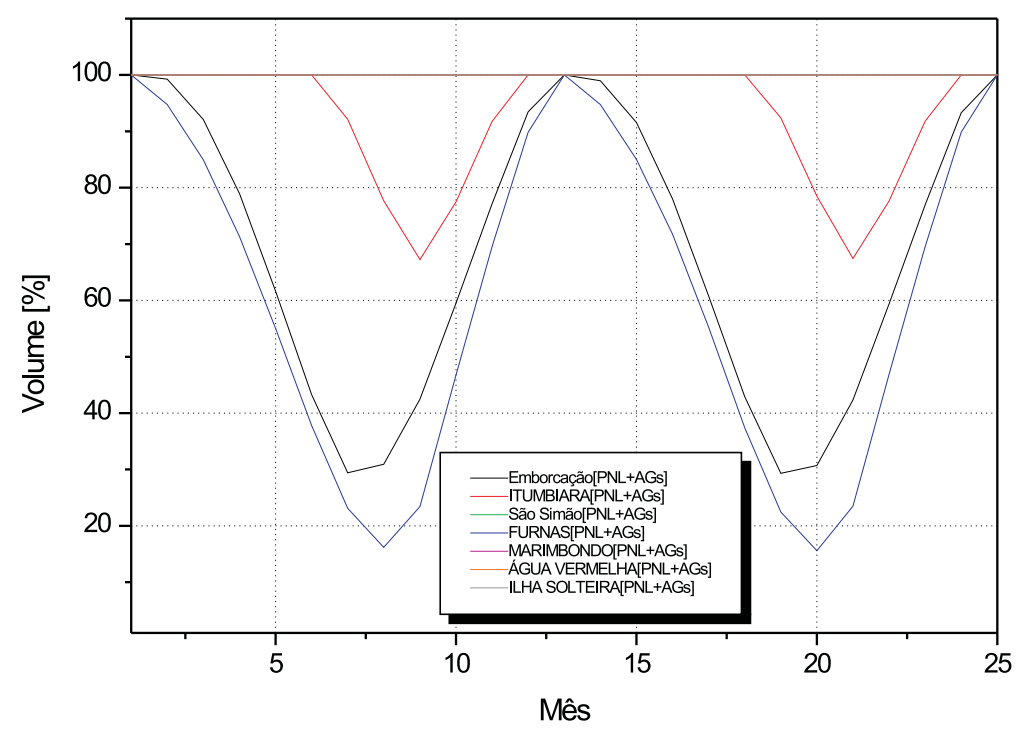

Figura 4.11: Estudo - Trajetória ótima de volume para as 7 usinas (PNL+AGs)

Como já mencionado anteriormente, trata-se de uma problema com uma função polinomial onde o menor custo será obtido quanto mais uniforme for a complementação térmica.

Neste caso, serão apresentadas as trajetórias de complementação térmica obtidas nos sistemas compostos de 1, 3 e 7 usinas, para que se possa analisar o comportamento dos algoritmos nos 4 grupos.

As complementações térmicas obtidas nos 3 testes e 4 grupos são apresentadas nas Figuras 4.12 a 4.17. Foram feitas ampliações da escala, em todos os testes, com objetivo de se verificar que as trajetórias de geração térmica ao longo do período de planejamento obtidas nos grupos 3 e 4 têm o mesmo comportamento, bem próximo das trajetórias definidas pelo PNL, no grupo 1. Esse bom desempenho apresentado pelos AGs, mostra que está técnica é eficiente e poderá ser utilizada sem dificuldade nos estudos e ações do planejamento da operação. 


\subsubsection{Uma usina isolada}

As trajetórias das complementações térmicas obtidas nos 4 grupos para uma usina isolada são apresentadas nas Figuras 4.12 e 4.13.

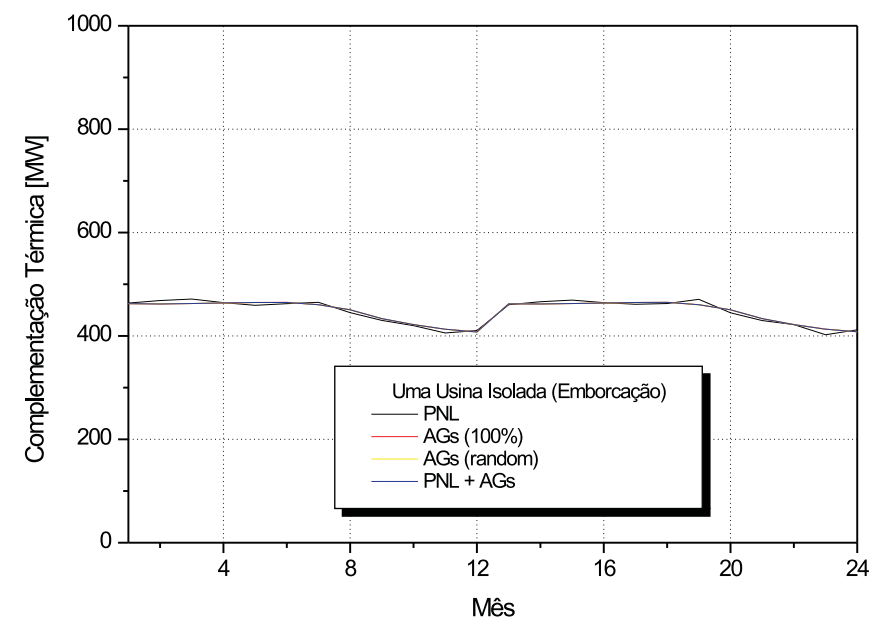

Figura 4.12: Estudo - Complementação térmica para uma usina isolada

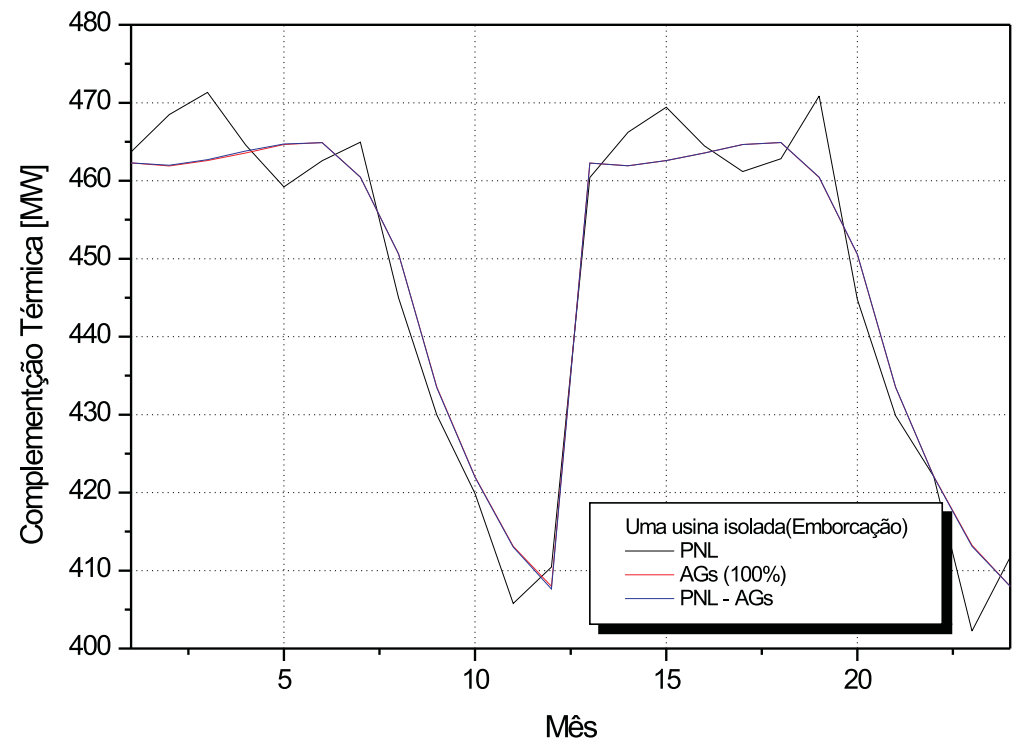

Figura 4.13: Estudo - Complementação térmica para uma usina isolada escala ampliada 


\subsubsection{Três usinas em cascata}

A seguir serão apresentadas as trajetórias das complementações térmicas obtidas nos 4 grupos para três usinas em cascata, sendo utilizadas neste sistema teste as usinas hidroelétricas de Emborcação, Itumbiara e São Simão.

Na Figura 4.14, observa-se que mesmo em um sistema mais complexo com 3 usinas em cascata, os AGs conseguem determinar uma operação para as usinas térmicas bem uniforme, seguindo aquela obtida pelo PNL.

Entretanto, quando a solução inicial é aleatória o algoritmo não mostrou um bom desempenho, pois apresenta oscilação ao longo do período de planejamento, conforme a trajetória obtida no grupo 2, AGs(aleatório).

Como atestado no caso de uma usina isolada, quando se trabalha com os AGs(100\%) e os AGs auxiliando o método baseado em PNL, o resultado é bastante satisfatório. Esse comportamento pode ser melhor visualizado na Figura 4.15.

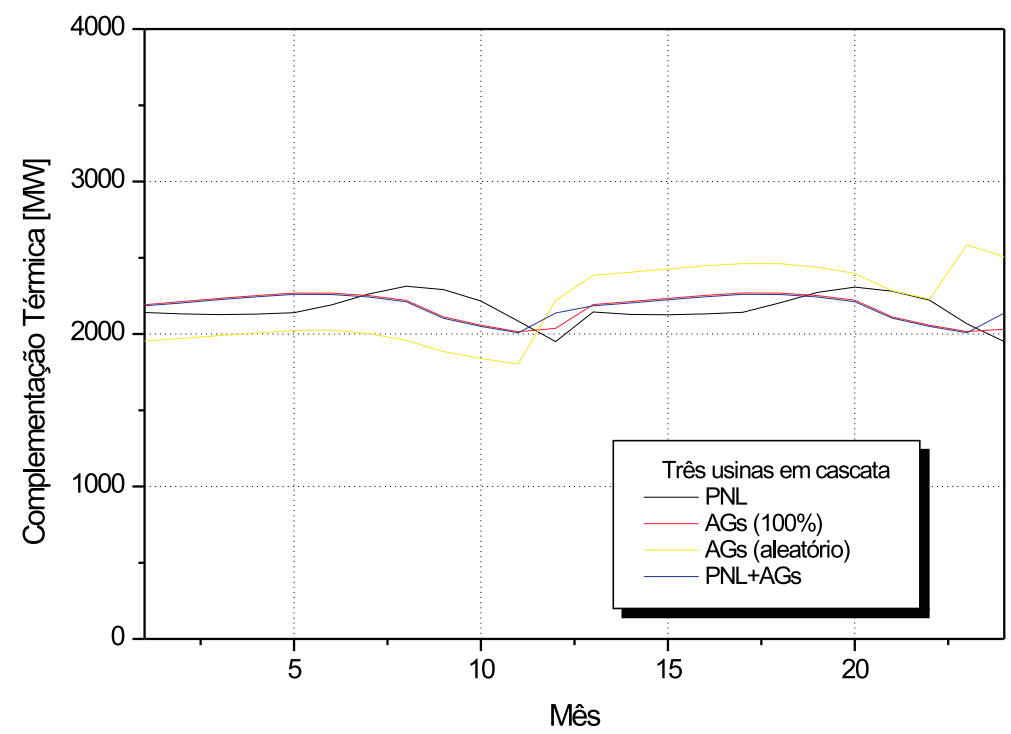

Figura 4.14: Estudo - Complementação térmica para três usinas em cascata 


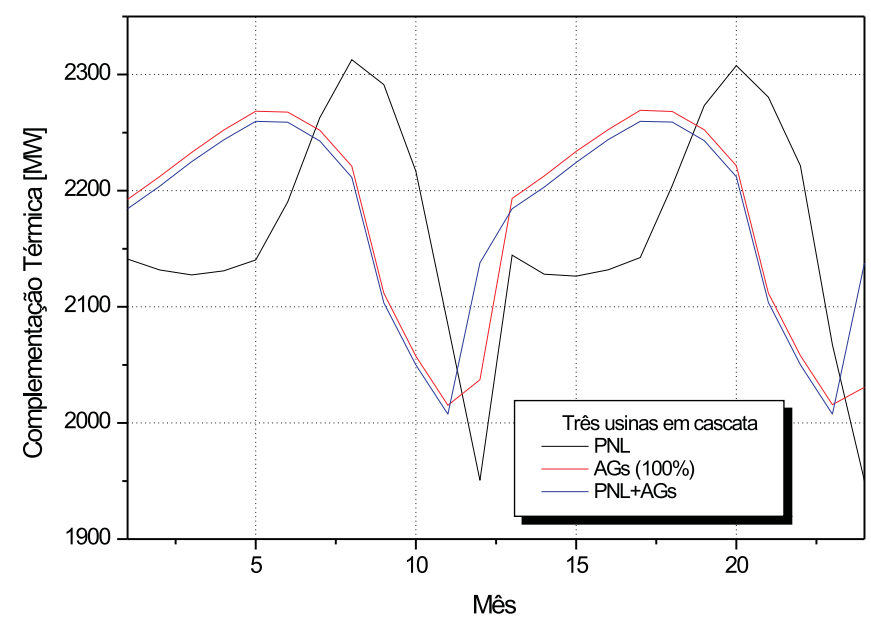

Figura 4.15: Estudo - Complementação térmica para três usinas em cascata escala ampliada

\subsubsection{Sete usinas em cascata}

Finalmente o último teste do Estudo apresenta as complementações térmicas utilizando um sistema formado por sete usinas, conforme apresentado na Figura 4.9. O desempenho do algoritmo proposto é mostrado na Figuras 4.16 e 4.17. Observe que os AGs mostraram-se eficientes quando usados como uma ferramenta auxiliar no POSHP (PNL+AGs), ou mesmo independente do PNL, pois os custos operativos em todos os 4 grupos são bem próximos.

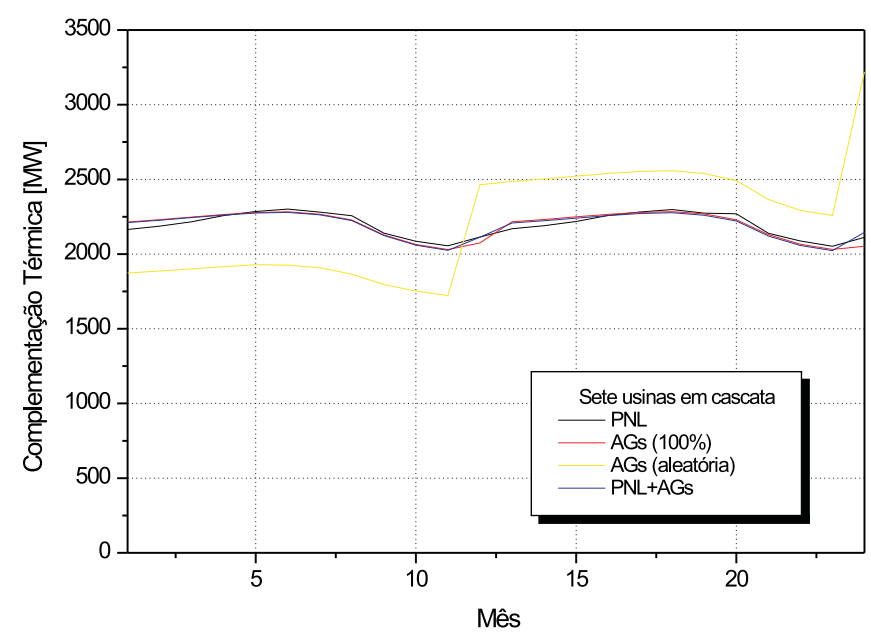

Figura 4.16: Estudo - Complementação térmica para sete usinas em cascata 


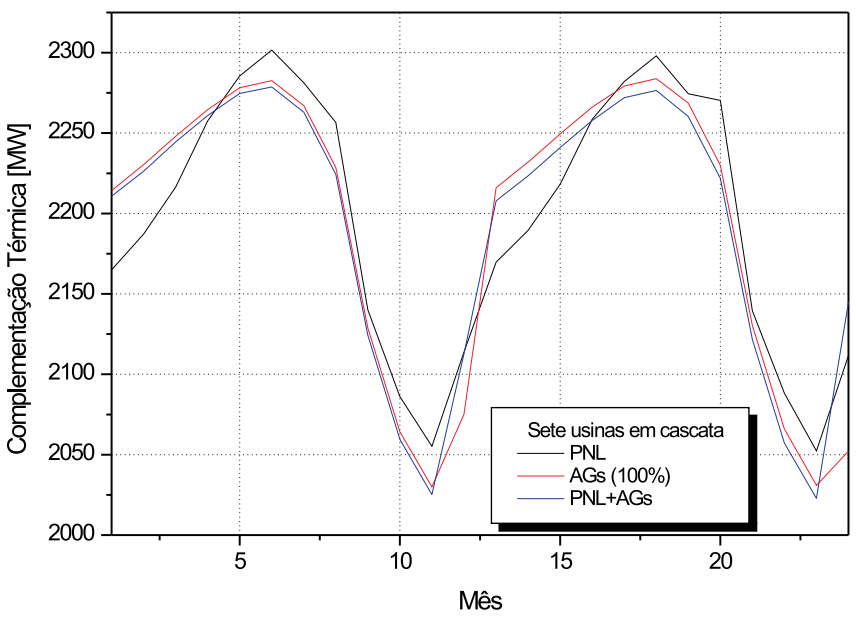

Figura 4.17: Estudo - Complementação térmica para sete usinas em cascata escala ampliada

Observe que neste Estudo foi desenvolvido para analisar o comportamento do algoritmo proposto após as várias adaptações feitas nos operadores genéticos tradicionais, para que se pudesse ter uma garantia do desempenho da técnica proposta e dar continuidade a aplicação em sistemas mais complexos e em situações operativas distintas.

No Apêndice C são apresentados alguns Estudos Complementares a esta fase do trabalho, onde investigou-se a aplicabilidade dos AGs ao problema do POSHP.

Atestada a viabilidade do algoritmo proposto, no próximo capítulo será apresentada uma avaliação dos parâmetros utilizados na configuração dos AGs. 


\section{Capítulo 5}

\section{Aprimoramento dos Parâmetros Utilizados}

\subsection{Introdução}

No Capítulo 4, foram adaptados vários operadores genéticos para o problema do POSHP. Para trabalhar com todos os operadores propostos e tipos de soluções iniciais definidas, é preciso uma ponderação com objetivo de obter uma configuração para que os AGs tenham um bom desempenho.

A ponderação indicará quantos filhos cada operador produzirá. Por exemplo, considere que há dois operadores genéticos de cruzamento e um de mutação, e a necessidade de gerar 25 filhos para a próxima geração. Considere também que foram atribuídos para os três operadores os pesos $w_{1}=40 \%, w_{2}=40 \%$ e $w_{3}=20 \%$, respectivamente. Então, o primeiro cruzamento produziria 10 filhos, o segundo cruzamento 10 filhos, e a mutação 5 filhos. Em geral, os pesos permanecem constantes por todas as gerações. Alternativamente, dependendo do operador e do problema, pode-se variar os pesos em cada geração para melhorar o desempenho do algoritmo.

Seguindo a idéia apresentada anteriormente, primeiramente foi elaborada uma bateria de testes, conforme apresentada na Tabela 5.1, com o mesmo número de gerações em todos os experimentos, na tentativa de definir o tamanho da população e o tipo de solução inicial que atendessem às necessidades do problema. Em segundo lugar foi feita a investigação dos pesos dos operadores genéticos e a contribuição desses em cada 
teste.

As soluções iniciais apresentadas na Tabela 5.1 são definidas como:

- Aleatório: volume(s) da(s) usina(s) poderão variar entre $0 \%$ e $100 \%$ do volume útil;

- 100\%: usina(s) com reservatório(s) cheio(s) (100\% do volume útil);

- Aleatório + 100\%: no caso de 3 e 7 usinas. As usinas de cabeceira serão aleatórias e as usinas a jusante com 100\% do volume útil;

- PNL: solução inicial gerada por PNL, para toda a população;

- PNL + aleatório: o primeiro indivíduo será gerado por PNL e os demais serão criados aleatoriamente.

Tabela 5.1: Conjunto de testes.

\begin{tabular}{|c|c|c|c|}
\hline Número de usinas & 1 & 3 & 7 \\
\hline Solução inicial & $\begin{array}{l}\text { Aleatório, } \\
100 \%, \quad \text { PNL, } \\
\text { PNL+aleatório }\end{array}$ & $\begin{array}{l}\text { Aleatório, } 100 \% \text {, } \\
\text { Aleatório+100\%, } \\
\text { PNL, } \\
\text { PNL+aleatório }\end{array}$ & $\begin{array}{l}\text { Aleatório, } 100 \% \text {, } \\
\text { Aleatório+100\%, } \\
\text { PNL, } \\
\text { PNL+aleatório }\end{array}$ \\
\hline Tamanho da população & $12-24-48$ & $12-24-48$ & $12-24-48$ \\
\hline \multicolumn{4}{|c|}{$\begin{array}{l}\text { Definido o tamanho de população ideal e solução inicial para cada } \\
\text { caso teste, a próxima etapa será definição do peso de cada operador }\end{array}$} \\
\hline Elitismo & \multicolumn{3}{|c|}{ Pesos } \\
\hline $\begin{array}{l}\text { Quantos indivíduos sofrerão } \\
\text { elitismo [\%] }\end{array}$ & $5 \%$ & $10 \%$ & $15 \%$ \\
\hline Cruzamento uniforme & \multicolumn{3}{|c|}{ Pesos } \\
\hline $\begin{array}{l}\text { Quantos indivíduos sofrerão } \\
\text { cruzamento [\%] }\end{array}$ & $0 \%$ & $30 \%$ & $60 \%$ \\
\hline \multicolumn{2}{|l|}{ Taxa de seleção } & \multicolumn{2}{|l|}{0.1} \\
\hline \multicolumn{2}{|l|}{ Taxa de cruzamento } & \multicolumn{2}{|l|}{0.1} \\
\hline Cruzamento médio & \multicolumn{3}{|c|}{ Pesos } \\
\hline $\begin{array}{l}\text { Quantos indivíduos sofrerão } \\
\text { cruzamento [\%] }\end{array}$ & $0 \%$ & $30 \%$ & $60 \%$ \\
\hline
\end{tabular}




\begin{tabular}{|c|c|c|c|}
\hline \multicolumn{2}{|l|}{ Taxa de seleção } & \multicolumn{2}{|l|}{0.1} \\
\hline \multicolumn{2}{|l|}{ Taxa de cruzamento } & \multicolumn{2}{|l|}{0.1} \\
\hline Mutação & \multicolumn{3}{|c|}{ Pesos } \\
\hline $\begin{array}{l}\text { Quantos indivíduos sofrerão } \\
\text { mutação [\%] }\end{array}$ & $5 \%$ & $10 \%$ & $15 \%$ \\
\hline \multicolumn{2}{|l|}{ Taxa de mutação } & \multicolumn{2}{|l|}{0.1} \\
\hline Mutação direcionada & \multicolumn{3}{|c|}{ Pesos } \\
\hline $\begin{array}{l}\text { Quantos indivíduos sofrerão } \\
\text { mutação [\%] }\end{array}$ & $5 \%$ & $10 \%$ & $15 \%$ \\
\hline \multicolumn{2}{|l|}{ Taxa de mutação } & \multicolumn{2}{|l|}{0.1} \\
\hline Mutação induzida & \multicolumn{3}{|c|}{ Pesos } \\
\hline $\begin{array}{l}\text { Quantos indivíduos sofrerão } \\
\text { mutação [\%] }\end{array}$ & $5 \%$ & $10 \%$ & $15 \%$ \\
\hline \multicolumn{2}{|l|}{ Taxa de mutação } & \multicolumn{2}{|l|}{0.1} \\
\hline Mutação local & \multicolumn{3}{|c|}{ Pesos } \\
\hline $\begin{array}{l}\text { Quantos indivíduos sofrerão } \\
\text { mutação [\%] }\end{array}$ & $5 \%$ & $10 \%$ & $15 \%$ \\
\hline \multicolumn{2}{|l|}{ Taxa de mutação } & \multicolumn{2}{|l|}{0.1} \\
\hline Mutação gradiente & \multicolumn{3}{|c|}{ Pesos } \\
\hline $\begin{array}{l}\text { Quantos indivíduos sofrerão } \\
\text { mutação [\%] }\end{array}$ & $5 \%$ & $10 \%$ & $15 \%$ \\
\hline \multicolumn{2}{|l|}{ Taxa de mutação } & \multicolumn{2}{|l|}{0.1} \\
\hline $\begin{array}{l}\text { Mutação gradiente dire- } \\
\text { cionada }\end{array}$ & \multicolumn{3}{|c|}{ Pesos } \\
\hline $\begin{array}{l}\text { Quantos indivíduos sofrerão } \\
\text { mutação [\%] }\end{array}$ & $5 \%$ & $10 \%$ & $15 \%$ \\
\hline Taxa de mutação & & 0.1 & \\
\hline
\end{tabular}

Esta etapa do trabalho foi bastante complexa, devido ao grande número de experimentos necessários e importantes, pois como pode ser visto na literatura, a definição dos parâmetros a serem utilizados em um algoritmo evolucionário gera grandes discussões e incertezas. Diversos pesquisadores trabalham exaustivamente neste ponto para que 
se obtenha um melhor desempenho do algoritmo.

\subsubsection{Tamanho da população e solução inicial}

O tamanho da população afeta diretamente o desempenho global e a eficiência dos AGs. Com uma população pequena, o desempenho pode cair, pois deste modo a população fornece uma pequena cobertura do espaço de busca do problema. Uma grande população geralmente fornece uma cobertura representativa do domínio do problema, além de prevenir convergências prematuras para soluções locais ao invés de globais, conforme já mencionado. O tipo de inicialização, ou seja, a solução inicial adotada, também pode contribuir para o sucesso da aplicabilidade do algoritmo.

Portanto, foram desenvolvidos alguns experimentos com a finalidade de encontrar um tamanho de população e uma solução inicial que apresentassem um bom desempenho na resolução do problema apontado. As configurações adotadas nestes, são mostradas na Tabela 5.2. Nesta fase do trabalho os operadores de mutação gradiente e mutação gradiente direcionada ainda não estavam totalmente implementados, por isso não fizeram parte dos estudos.

Tabela 5.2: Configuração da população utilizada nos testes para analisar o tamanho da população e a solução inicial

\begin{tabular}{|l||l||l||l|}
\hline Operadores genéticos & \multicolumn{3}{l|}{ Número de indivíduos } \\
\hline Elitismo & 01 & 02 & 04 \\
\hline Cruzamento uniforme & 02 & 04 & 08 \\
\hline Cruzamento uniforme + mutação & 01 & 02 & 04 \\
\hline Cruzamento médio & 02 & 04 & 08 \\
\hline Cruzamento médio + mutação & 01 & 02 & 04 \\
\hline Mutação & 01 & 02 & 04 \\
\hline Mutação direcionada & 01 & 02 & 04 \\
\hline Mutação induzida & 01 & 02 & 04 \\
\hline Busca local & 02 & 04 & 08 \\
\hline População total & $\mathbf{1 2}$ & $\mathbf{2 4}$ & $\mathbf{4 8}$ \\
\hline
\end{tabular}

Os resultados obtidos são mostrados na Tabela 5.3, com custo médio, desvio padrão, coeficiente de variação e teste de hipótese. Para analisar a viabilidade dos parâmetros definidos, cada teste foi repetido pelo menos 20 vezes, com um mesmo número de gerações, para que se tenha uma estatística significativa dos valores obtidos. 


\subsubsection{Teste de hipótese}

Os testes de hipóteses são muito utilizados para realizar comparações entre as medidas de duas distribuições que podem, por exemplo, representar experimentos distintos para a solução de um mesmo problema. Considere que se deseja comparar dois experimentos para saber se um deles (experimento 1) gera, em média, soluções menores que o outro (experimento 2). Formaliza-se tal teste gerando duas hipóteses: (1) a hipótese nula $\left(H_{0}\right)$ de que à média das soluções obtidas com o experimento $1\left(\mu_{1}\right)$ é menor que ou igual a média das soluções obtidas com o experimento $2\left(\mu_{2}\right)$, e $(2)$ a hipótese alternativa $\left(H_{1}\right)$ que vai de encontro à hipótese nula, considerando que a média das soluções obtidas com o experimento 1 é maior que a média das soluções com o experimento 2. Portanto:

$$
\begin{aligned}
& H_{0}: \mu_{1} \leq \mu_{2} \text { ou } \mu_{1}-\mu_{2} \leq 0 \\
& H_{1}: \mu_{1}>\mu_{2} \text { ou } \mu_{1}-\mu_{2}>0
\end{aligned}
$$

Nos testes de hipóteses podem ocorrer dois tipos de erros. Primeiro tipo de erro, a hipótese nula é rejeitada quando for verdadeira. No segundo tipo de erro, a hipótese nula não é rejeitada quando for falsa. As probabilidades de ocorrência destes dois erros são dadas por:

$\alpha=P($ ocorrência de erro do tipo 1$)=P\left(\right.$ rejeita $H_{0} \mid H_{0}$ é verdadeira $)$

$$
\beta=P(\text { ocorrência de erro do tipo } 2)=P\left(\text { falha ou rejeitar } H_{0} \mid H_{0} \text { é falso }\right)
$$

$\mathrm{Na}$ execução geral de um teste de hipótese é especificado um valor baixo, como por exemplo, $5 \%$ ou $1 \%$, para a probabilidade $\alpha$ de ocorrência do erro tipo 1 , que frequentemente é conhecida como nível de significância. A hipótese nula aqui tratada é construída sobre a diferença entre as médias dos dois experimentos analisados, e para a determinação do valor de $\beta$ seria necessário testar diversos valores para esta diferença entre médias. Isto torna difícil conhecer $\beta$. Na prática, sabe-se que no geral o valor de $\beta$ decresce conforme aumenta o número de amostras das distribuições tomadas para realizar o experimento [MONTGOMERY (1984)], e assim pode-se reduzir a probabilidade de erro do tipo 2 . 
O teste de hipótese foi realizado com o objetivo de validar a hipótese nula com um nível de significância estabelecido. Para tal, segue-se o procedimento geral de: (a) calcular uma estatística das amostras obtidas [MORETTIN \& BUSSAB (1984)]; (b) criar uma região crítica (ou de rejeição, a partir do valor de $\alpha$ estabelecido para o teste, que é um conjunto de valores para os quais a hipótese nula é rejeitada e (c) caso a estatística calculada esteja dentro da região crítica, rejeitar a hipótese $H_{0}$; caso contrário, aceitar $H_{0}$ como verdadeira. Portanto para o teste de hipóteses apresentado nas equações 5.1 e 5.2 , os passos serão:

1. Considere o caso mais geral e realista de que não se possui conhecimento prévio sobre as médias e as variância das distribuições geradas pelos processos em análise, que as variâncias sejam desiguais, e as amostras sejam independentes. Nesse caso é indicado por [ MORETTIN \& BUSSAB (1984)] o uso da seguinte estatística $t$ sobre as amostras dos dois procedimentos, como apresentada na equação 5.5 :

$$
t=\frac{(\bar{X}-\bar{Y})-\left(\mu_{1}-\mu_{2}\right)}{\sqrt{S_{1}^{2} / n+S_{2}^{2} / m}}
$$

sendo:

$n$ e $m=$ número de elementos dos experimentos 1 e 2 , respectivamente;

$\bar{X}=\frac{1}{n} \sum_{1}^{n} X_{i}$ (média estimada) e $S_{1}^{2}=\frac{1}{n-1} \sum_{1}^{n}\left(X_{i}-\bar{X}^{2}\right.$ ) (variância estimada)

$\bar{Y}=\frac{1}{m} \sum_{1}^{m} Y_{i} \quad$ (média estimada) e $S_{2}^{2}=\frac{1}{m-1} \sum_{1}^{m}\left(Y_{i}-\bar{Y}^{2}\right.$ ) (variância estimada)

$X_{i}$ e $Y_{i}$ - amostras dos experimentos 1 e 2 , respectivamente.

A distribuição de $t$ será uma distribuição $t$ de Student com $v$ graus de liberdade.

Onde graus de liberdade são essencialmente um ajuste no número de parâmetros da distribuição em função do tamanho da amostra observada [MASON et al. (1998)], em que:

$$
v=\frac{\left(\frac{S_{1}^{2}}{n}+\frac{S_{2}^{2}}{m}\right)^{2}}{\frac{\left(\frac{S_{1}^{2}}{n}\right)^{2}}{n-1}+\frac{\left(\frac{S_{2}^{2}}{n}\right)^{2}}{m-1}}
$$

2. A estatística usada sobre as amostra tem por objetivo levar a distribuição padrão, 
em geral a distribuição normal com média zero e variância unitária $N(0,1)$, de forma a que se possa utilizar tabelas para construir a região crítica dado o nível de significância $\alpha$ do teste. Como as variâncias das distribuições geradas pelos procedimentos são desconhecidas (podem apenas ser estimadas por $S_{1}^{2}$ e $S_{2}^{2}$ ) não há informação suficiente para realizar diretamente a transformação para $n(0,1)$, assim a distribuição da estatística $t$ da equação 5.6, é uma aproximação de $N(0,1)$ denominada de distribuição $t$ de Student em que quanto maior grau de liberdade $v$, melhor é esta aproximação. Com isso, a região crítica (RC) do teste de hipóteses apresentado nas equações 5.1 e 5.2 é:

$$
R C=\left\{|t|>t_{c}\right\}
$$

onde, tc é obtido em uma tabela da distribuição $t$ de Student de tal forma que $P(t \in R \mid t>t c)=\alpha$ com $v$ graus de liberdade. Para este trabalho onde o número de amostra é $20 \rightarrow t \approx 2,539$.

3. Calculando-se $t$ a partir dos dados amostrados, caso o valor da estatística $t$ pertença a $R C$, rejeite a hipótese $H_{0}$; caso o valor de $t$ não pertença a $R C$, então aceite a hipótese $H_{0}$ como verdadeira com probabilidade $\alpha$ de erro. $\mathrm{O}$ valor de $\alpha$ adotado nos experimentos apresentados na Tabela 5.3 é 0.01 .

A seguir serão aplicados os passos acima explicados sobre os dados obtidos nos experimentos que indicarão o tamanho de população e solução inicial mais satisfatória, e em seguida será feita a ponderação dos operadores genéticos.

\subsubsection{Aplicação do teste de hipótese}

Uma usina isolada: através da Tabela 5.3, observam-se os custos de operação dos experimentos que foram executados e os testes de hipóteses que foram aplicados com objetivo de encontrar um tamanho de população e solução inicial que fornecessem, em média, o menor custo de operação.

Os experimentos foram divididos, para este caso, em 4 grupos distintos de acordo com as soluções iniciais propostas, e dentro de cada grupo foram executados 3 experimentos, variando o tamanho de população em 12, 24 e 48 indivíduos respectivamente. 
Primeiramente foi determinado em cada grupo qual o experimento apresentou, em média, a menor solução ou menor custo de operação, mesmo sabendo que estes não sofreram grandes variações. Feita esta análise através do teste de hipóteses, pode-se concluir que:

- grupo 1 = hipótese nula aceita, foi dada pelo experimento 1B;

- grupo 2 = hipótese nula aceita, foi dada pelo experimento 1D;

- grupo 3 = hipótese nula aceita, foi dada pelo experimento 1I;

- grupo 4 = hipótese nula aceita, foi dada pelo experimento $1 \mathrm{k}$;

A segunda etapa dessa fase do trabalho foi a de determinar, baseado nas hipóteses nulas aceitas em cada grupo, qual forneceria, em média, o menor custo operativo para o sistema. Utilizando o teste de hipóteses, pode-se concluir que a hipótese aceita que gera, em média, o menor custo é dada pelo experimento 1D. Onde a população é composta por 12 indivíduos e solução inicial aleatória.

Como trata-se de um sistema teste simples, mesmo com uma solução inicial aleatória, o algoritmo não tem dificuldade de encontrar a melhor solução, e não necessita de um conhecimento prévio do comportamento do sistema. Observe que independentemente do tamanho da população e solução inicial os AGs obtiveram resultados próximos e um coeficiente de variação pequeno.

Portanto, apesar do teste de hipótese ter indicado o experimento 1D, como a melhor configuração, faz-se necessário testes com sistemas mais complexos, com mais usinas, para verificar o comportamento do algoritmo proposto, e para que se possa adotar uma configuração mais segura é confiável.

Sendo assim, foram desenvolvidos experimentos com sistemas teste compostos de 3 e 7 usinas, como pode ser visto a seguir.

Três usinas em cascata: para 3 usinas em cascata foi acrescentado mais um grupo de experimentos, onde adota-se solução inicial igual a 100\%+aleatório, conforme apresentado na Tabela 5.3.

Observe que os valores dos coeficientes de variação apresentados na Tabela 5.3, para o caso de 3 usinas, são maiores em alguns casos, o que reforça a necessidade de 
aplicar as mesmas análises e procedimentos adotados no sistema com 1 usina. Portanto, as hipóteses nulas aceitas, para cada grupo, são as seguintes:

- grupo 1 = hipótese nula aceita, foi dada pelo experimento 3B;

- grupo 2 = hipótese nula aceita, foi dada pelo experimento 3F;

- grupo 3 = hipótese nula aceita, foi dada pelo experimento 3I;

- grupo 4 = hipótese nula aceita, foi dada pelo experimento 3J;

- grupo 5 = hipótese nula aceita, foi dada pelo experimento $3 \mathrm{M}$;

O próximo passo foi aplicar o teste de hipótese no conjunto de hipóteses nulas aceita em cada grupo. Sendo assim, a hipótese nula aceita foi dada pelo experimento 3J. Onde a população é composta por 12 indivíduos e solução fornecida pelo PNL (ou seja, um conhecimento prévio do espaço de solução é passado para os AGs), conforme apresentado na Tabela 5.3. Essa informação, atesta mais uma vez a idéia sobre a possibilidade de se trabalhar com AGs em conjunto com uma heurística, os chamados Sistemas Genéticos Híbridos.

Sete usinas em cascata: seguindo a mesma idéia apresentada anteriormente e baseando-se nos dados apresentados na Tabela 5.3, tem-se:

- grupo 1 = hipótese nula aceita, foi dada pelo experimento 7B;

- grupo 2 = hipótese nula aceita, foi dada pelo experimento 7F;

- grupo 3 = hipótese nula aceita, foi dada pelo experimento 7I;

- grupo 4 = hipótese nula aceita, foi dada pelo experimento 7J;

- grupo 5 = hipótese nula aceita, foi dada pelo experimento 7M;

Após a aplicação do teste de hipóteses, pode-se concluir que, para o sistema teste composto por 7 usinas em cascata, o comportamento dos AGs foi o mesmo do sistema com 3 usinas, pois a hipótese nula aceita, foi dada pelo experimento 7J, segundo apresentado na Tabela 5.3. Sendo a população formada por 12 indivíduos e solução inicial fornecida pelo PNL, ou seja os AGs receberam auxílio de uma outra técnica. 
Mas vale ressaltar que, o PNL pode apresenta algumas imperfeições e dificuldades de convergência, principalmente em casos onde as afluências adotadas são dadas pelo histórico das vazões e não mais pela MLT, como já mencionado anteriormente.

Por este motivo, não serão adotadas as configurações fornecidas pelos experimentos 3J e 7J, para análise final e nos próximos estudos. Sendo assim, uma última análise foi feita, apenas considerando as soluções iniciais independentes do PNL. No caso de 3 usinas, a hipótese nula é fornecida pelo experimento 3B. No caso de 7 usinas, foi o experimento 7B. Ambos apresentam a mesma configuração para a população, ou seja, 24 indivíduos e solução inicial igual a 100\% do volume útil. Portanto essa será a configuração adotada na ponderação dos operadores genéticos.

Tabela 5.3: Definição do tamanho da população e solução inicial.

\begin{tabular}{|c|c|c|c|c|c|c|c|c|}
\hline \multirow[t]{2}{*}{ Experimento } & \multirow[t]{2}{*}{ Usina } & \multicolumn{2}{|c|}{$\begin{array}{l}\text { Parâmetros investiga- } \\
\text { dos }\end{array}$} & \multirow[t]{2}{*}{$\begin{array}{l}\text { Custo } \\
\text { médio }\end{array}$} & \multirow[t]{2}{*}{$\begin{array}{l}\text { Melhor } \\
\text { custo }\end{array}$} & \multirow[t]{2}{*}{$\begin{array}{l}\text { Desvio } \\
\text { Padrão }\end{array}$} & \multirow{2}{*}{$\begin{array}{l}\text { Coeficiente } \\
\text { de } \\
\text { variação }\end{array}$} & \multirow{2}{*}{$\begin{array}{l}\text { Teste } \\
\text { de } \\
\text { hipótese }\end{array}$} \\
\hline & & $\begin{array}{l}\text { Tam. } \\
\text { pop }\end{array}$ & $\begin{array}{l}\text { Solução } \\
\text { inicial }\end{array}$ & & & & & \\
\hline $1 \mathrm{~B}$ & 1 & 24 & $100 \%$ & 918483.27 & 918482.68 & 0.38 & 0.00004 & Aceita \\
\hline $1 \mathrm{C}$ & 1 & 48 & $100 \%$ & 918483.21 & 918482.73 & 0.40 & 0.00004 & Rejeita \\
\hline $1 \mathrm{~F}$ & 1 & 48 & Aleatório & 918482.10 & 918481.68 & 0.36 & 0.00004 & Rejeita \\
\hline $1 \mathrm{G}$ & 1 & 12 & PNL & 918482.93 & 918482.42 & 0.29 & 0.00003 & Rejeita \\
\hline $1 \mathrm{H}$ & 1 & 24 & PNL & 918482.95 & 918482.57 & 0.22 & 0.00002 & Rejeita \\
\hline $1 \mathrm{I}$ & 1 & 48 & PNL & 918482.56 & 918482.03 & 0.40 & 0.00004 & Aceita \\
\hline $1 \mathrm{~J}$ & 1 & 12 & PNL+aleatório & 918482.92 & 918482.42 & 0.25 & 0.00003 & Rejeita \\
\hline $3 \mathrm{~A}$ & 3 & 12 & $100 \%$ & 21441274.27 & 21440977.04 & 186.91 & 0.00087 & Rejeita \\
\hline $3 \mathrm{~B}$ & 3 & 24 & $100 \%$ & 21440751.8 & 21440382.3 & 126.99 & 0.00059 & Aceita \\
\hline
\end{tabular}




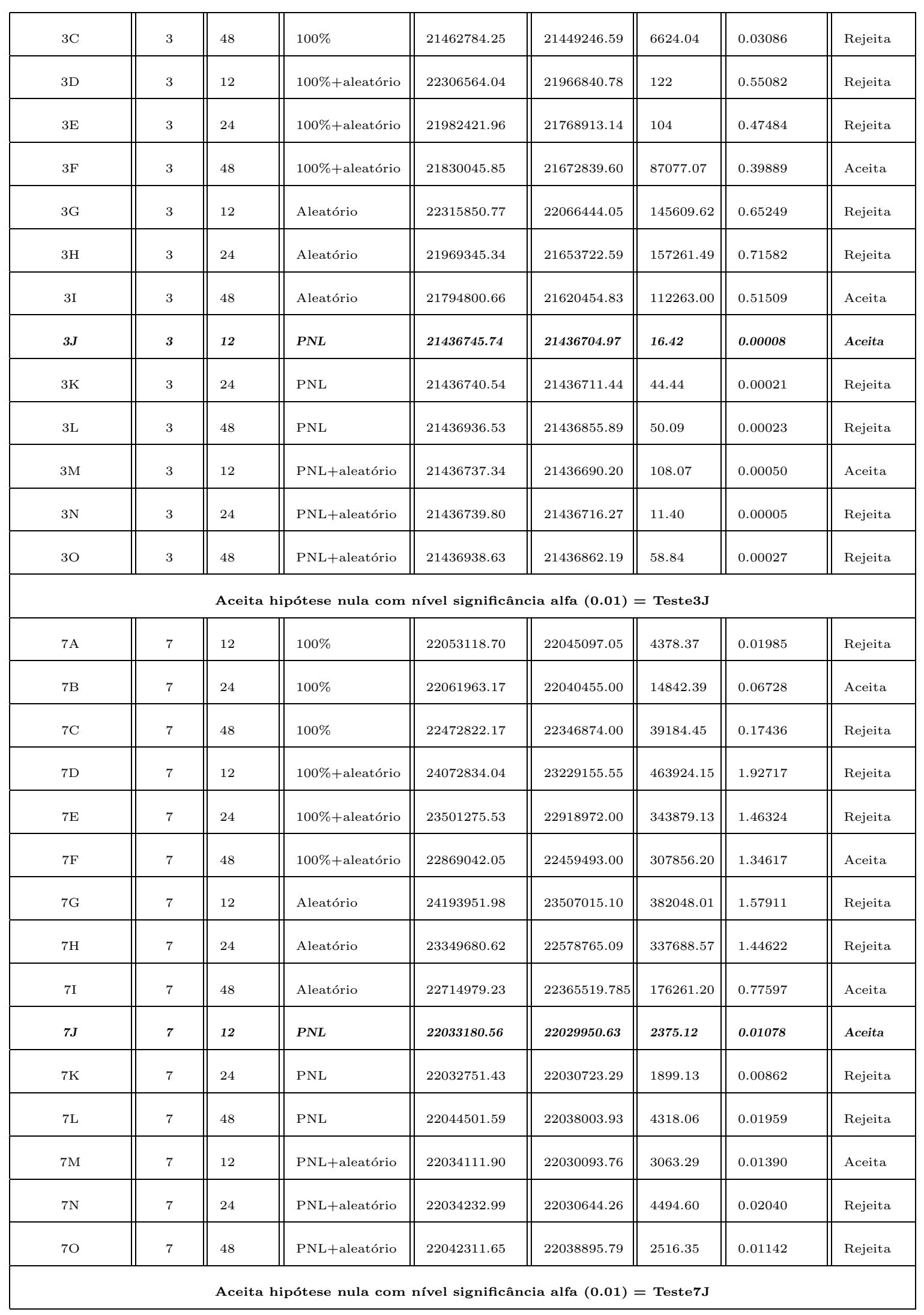




\subsubsection{Ponderação dos operadores genéticos}

Os operadores genéticos utilizados nos experimentos para a realização da ponderação destes operadores, são apresentados na Tabela 5.4 e tem a seguinte distribuição:

\section{Elitismo;}

2. Cruzamento uniforme;

3. Mutação após cruzamento uniforme;

4. Cruzamento médio;

5. Mutação após cruzamento médio;

6. Mutação local;

7. Mutação;

8. Mutação direcionada;

9. Mutação gradiente direcionada;

10. Mutação gradiente;

11. Mutação induzida.

Nesta fase os operadores baseados no método do gradiente foram introduzidos.

Na Tabela 5.4, pode-se observar os vários conjuntos de experimentos que foram elaborados para o estudo de ponderação dos operadores genéticos implementados nessa pesquisa, bem como as configurações utilizadas, o custo médio de operação, o desvio padrão e o coeficiente de variação. Todos os testes foram realizados para uma população composta de 24 indivíduos, solução inicial igual a 100\% do volume útil, sistema teste com 3 usinas em cascata e um mesmo número de gerações.

Estes experimentos foram divididos em 3 grupos, conforme apresentado na Tabela 5.4. No grupo A, experimentos de $1 \mathrm{~A}$ a $8 \mathrm{~A}$, foi utilizado apenas o cruzamento uniforme e variou-se a quantidade de indivíduo nos demais operadores genéticos de mutações e no elitismo. No grupo B, experimentos de 1B a 8B, utilizou-se somente cruzamento médio e variou-se a quantidade de indivíduos nos demais operadores genéticos. Finalmente, no 
grupo C, do experimento 1C a 8C, foram utilizados os dois operadores de cruzamentos implementados, e a distribuição nos demais operadores seguiu a mesma idéia do grupo A e B.

Observe, na Figura 5.1, que os valores obtidos nos experimentos, com legenda (A), onde apenas o cruzamento uniforme é utilizado e com legendas (B), onde apenas se faz o uso do cruzamento médio, apresentaram resultados próximos, definindo um trajetória praticamente uniforme. O mesmo ocorrendo nos experimentos com legenda (C), onde utilizou-se uma combinação dos dois tipos de operadores de cruzamento. Através do gráficos apresentado na Figura 5.1, não se pode ter uma visualização de qual experimento apresentou o melhor desempenho, apenas observa-se a robustez dos AGs, pois independente da combinação dos operadores genéticos os resultados são muito próximos. Portanto, optou-se por apresentar os valores através da Tabela 5.4.

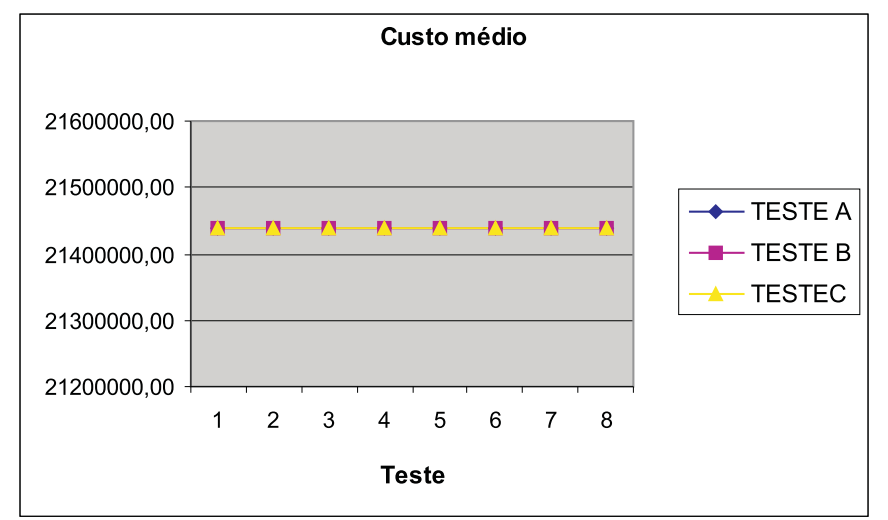

Figura 5.1: Custo médio na análise dos operadores de cruzamentos propostos.

Como os resultados foram bastante próximos e o coeficiente de variação foi pequeno, conforme apresentado na Tabela 5.4, para saber se é necessário utilizar todos os operadores implementados, seria necessário realizar mais experimentos variando a configuração. Mas ressalta-se que, existem várias possibilidades de configurações que poderiam ser exploradas, e isso levaria algum tempo de investigação, o que poderia atrasar a aplicação do algoritmo proposto em sistemas testes com maior número de usinas e situação operativa distinta.

Por isso, decidiu-se tomar a configuração que fornecesse o menor custo de operação em um número de geração fixo para concluir a pesquisa. Portanto, através dos resultados, apresentados na Tabela 5.4, observa-se que o teste 5B apresentou, em média, o 
menor custo de operação.

Tabela 5.4: Configurações das populações adotadas nos testes de ponderação dos operadores genéticos.

\begin{tabular}{|c|c|c|c|c|c|c|c|c|c|c|c|c|c|c|}
\hline \multirow[t]{2}{*}{ Experimentos } & \multicolumn{11}{|c|}{ Operadores genéticos invetigados } & \multirow{2}{*}{$\begin{array}{l}\text { Custo } \\
\text { médio }\end{array}$} & \multirow{2}{*}{$\begin{array}{l}\text { Desvio } \\
\text { Padrão }\end{array}$} & \multirow{2}{*}{$\begin{array}{l}\text { Coeficiente } \\
\text { variação }\end{array}$} \\
\hline & 1 & 2 & 3 & 4 & 5 & 6 & 7 & 8 & 9 & 10 & 11 & & & \\
\hline $1 \mathrm{~A}$ & 2 & 8 & 2 & 0 & 0 & 2 & 2 & 2 & 3 & 2 & 1 & 21438733.54 & 148.402014 & 0.000007 \\
\hline $2 \mathrm{~A}$ & 2 & 8 & 2 & 0 & 0 & 2 & 1 & 2 & 3 & 2 & 2 & 21438758.94 & 179.062471 & 0.000008 \\
\hline $3 \mathrm{~A}$ & 2 & 8 & 2 & 0 & 0 & 2 & 2 & 1 & 3 & 2 & 2 & 21438800.69 & 171.314116 & 0.000008 \\
\hline $4 \mathrm{~A}$ & 2 & 8 & 2 & 0 & 0 & 4 & 2 & 1 & 3 & 2 & 1 & 21438728.43 & 155.406767 & 0.000007 \\
\hline $5 \mathrm{~A}$ & 3 & 8 & 2 & 0 & 0 & 3 & 1 & 1 & 3 & 2 & 1 & 21438781.54 & 177.264002 & 0.000006 \\
\hline $6 \mathrm{~A}$ & 1 & 8 & 2 & 0 & 0 & 3 & 3 & 1 & 3 & 2 & 1 & 21438741.96 & 145.791849 & 0.000009 \\
\hline $7 \mathrm{~A}$ & 2 & 8 & 2 & 0 & 0 & 2 & 2 & 2 & 3 & 2 & 1 & 21438698.79 & 154.874482 & 0.000008 \\
\hline $8 \mathrm{~A}$ & 1 & 8 & 2 & 0 & 0 & 2 & 1 & 1 & 3 & 2 & 4 & 21438758.52 & 182.944915 & 0.000008 \\
\hline $1 \mathrm{~B}$ & 2 & 0 & 0 & 8 & 2 & 2 & 2 & 2 & 3 & 2 & 1 & 21438722,37 & 179.0624707 & 0.000008 \\
\hline $2 \mathrm{~B}$ & 2 & 0 & 0 & 8 & 2 & 2 & 1 & 2 & 3 & 2 & 2 & 21438713.01 & 155.4067668 & 0.000007 \\
\hline 3B & 2 & 0 & 0 & 8 & 2 & 2 & 2 & 1 & 3 & 2 & 2 & 21438724.41 & 145.7918487 & 0.000007 \\
\hline $4 \mathrm{~B}$ & 2 & 0 & 0 & 8 & 2 & 4 & 2 & 1 & 3 & 2 & 1 & 21438782.92 & 182.9449155 & 0.000009 \\
\hline $5 \mathrm{~B}$ & 3 & 0 & 0 & 8 & 2 & 3 & 1 & 1 & 3 & 2 & 1 & 21438673.10 & 140.5904841 & 0.000007 \\
\hline $6 \mathrm{~B}$ & 1 & 0 & 0 & 8 & 2 & 3 & 3 & 1 & 3 & 2 & 1 & 21438759.05 & 140.9897346 & 0.000007 \\
\hline $7 \mathrm{~B}$ & 2 & 0 & 0 & 8 & 2 & 2 & 2 & 2 & 3 & 2 & 1 & 21438721.56 & 214.0068863 & 0.000001 \\
\hline $8 \mathrm{~B}$ & 1 & 0 & 0 & 8 & 2 & 2 & 1 & 1 & 3 & 2 & 4 & 21438746.91 & 163.7440236 & 0.000008 \\
\hline $1 \mathrm{C}$ & 2 & 4 & 1 & 4 & 1 & 2 & 2 & 2 & 3 & 2 & 1 & 21438726.09 & 167.3005490 & 0.000008 \\
\hline $2 \mathrm{C}$ & 2 & 4 & 1 & 4 & 1 & 2 & 1 & 2 & 3 & 2 & 2 & 21438745.80 & 186.8869627 & 0.000009 \\
\hline $3 \mathrm{C}$ & 2 & 4 & 1 & 4 & 1 & 2 & 2 & 1 & 3 & 2 & 2 & 21438717.05 & 140.3296870 & 0.000007 \\
\hline $4 \mathrm{C}$ & 2 & 4 & 1 & 4 & 1 & 4 & 2 & 1 & 3 & 2 & 1 & 21438803.65 & 187.5532205 & 0.000009 \\
\hline $5 \mathrm{C}$ & 3 & 4 & 1 & 4 & 1 & 3 & 1 & 1 & 3 & 2 & 1 & 21438728.84 & 195.4129231 & 0.000009 \\
\hline $6 \mathrm{C}$ & 1 & 4 & 1 & 4 & 1 & 3 & 3 & 1 & 3 & 2 & 1 & 21438798.81 & 150.4411058 & 0.000007 \\
\hline $7 \mathrm{C}$ & 2 & 4 & 1 & 4 & 1 & 2 & 2 & 2 & & 2 & 1 & 21438722.59 & 113.1082388 & 0.000005 \\
\hline $8 \mathrm{C}$ & 1 & 4 & 1 & 4 & 1 & 2 & 1 & 1 & 3 & 2 & 4 & 21438810.97 & 174.0281284 & 0.000008 \\
\hline
\end{tabular}


Observe através da Tabela 5.4, que a diferença entre os custos e o coeficiente de variação são pequenos. Portanto, não se pode descartar nenhum tipo de operador até que esta investigação seja totalmente concluída, apenas pode-se, para este momento, e com estes experimentos, adotar a configuração que forneceu um bom resultado em um tempo computacional menor.

No próximo Capítulo, serão apresentados vários Estudos sobre aplicação do algoritmo proposto em sistemas testes compostos por usinas pertencentes ao Sistema Brasileiro, em diversas situações operativas, para análise da aplicabilidade do algoritmo proposto no POSHP.

Nestes Estudos foi adotada população composta por 24 indivíduos, solução inicial igual a 100\% do volume útil e indivíduos distribuídos conforme experimento 5B. O objetivo dessa fase foi o de indicar uma configuração eficiente para os AGs, principalmente para aplicação em sistemas testes com muitas usinas, como por exemplo 35 usinas. Onde uma configuração mal elaborada poderia acarretar em um tempo computacional maior de execução. 


\section{Capítulo 6}

\section{Aplicações no Sistema Brasileiro}

\subsection{Intodução}

O algoritmo proposto foi aplicado em sistemas testes compostos por usinas hidroelétricas pertencentes ao Sistema Sudeste Brasileiro, conforme Figura 6.1, com dados reais, em algumas condições operativas, procurando reproduzir as mesmas situações encontradas nos estudos e ações de Planejamento da Operação de Sistemas Hidrotérmicos de Potência, visando determinar o cronograma ótimo de operação.

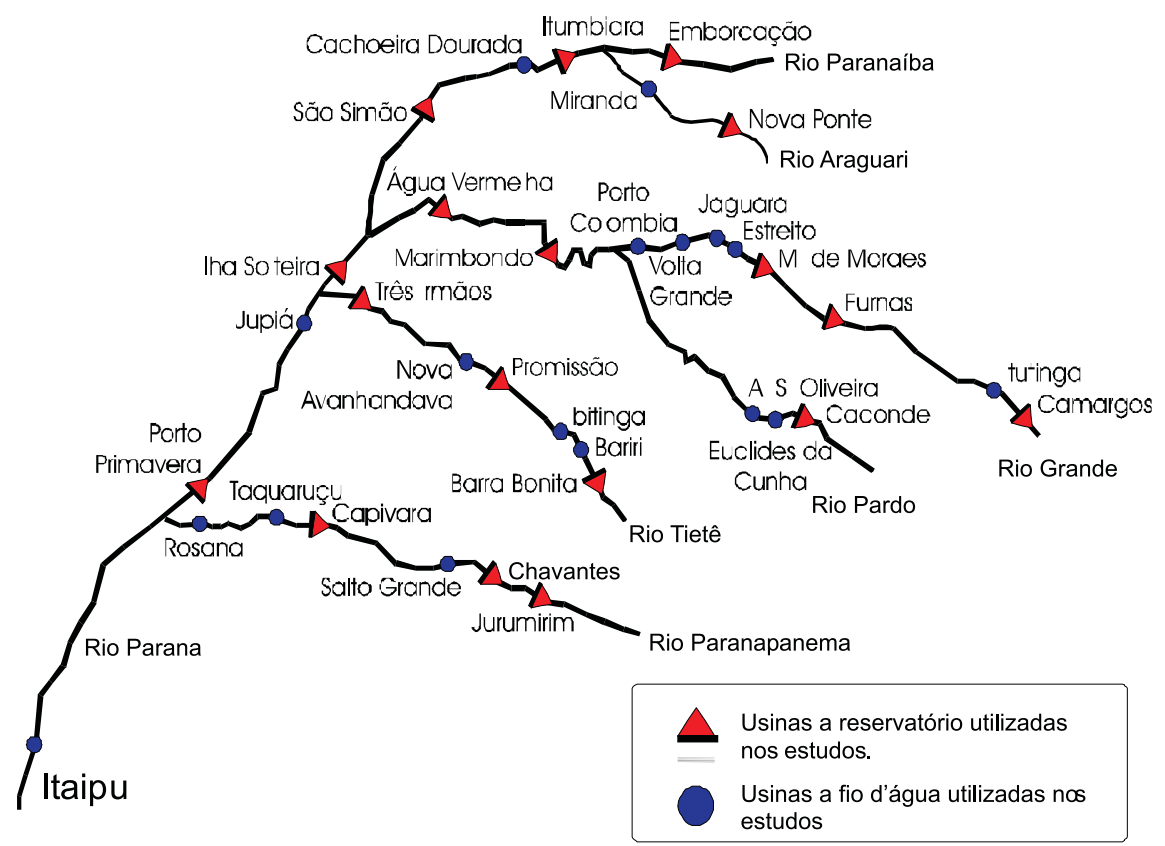

Figura 6.1: Parte do Sistema Sudeste Brasileiro 
Nestes estudos, variaram-se os números e as configurações das usinas envolvidas, bem como os períodos de afluências do passado a que foram submetidas. Em alguns testes foram também usadas as vazões chamadas Média de Longo Termo (MLT), representadas pelas médias, em cada um dos 12 meses, das vazões registradas no passado.

As usinas hidroelétricas brasileiras dispõem de dados históricos de vazões afluentes naturais com início no ano de 1931 até 2001. Esse dados estão disponíveis em discretização mensal ou semanal, tendo sido obtidos a partir de um processo baseado em medições e análises, encontrando-se no seguinte site: www.ons.org.br.

Em todos os Estudos, foi considerada a influência da taxa de desconto, em $10 \%$ ao ano, consoante ofício SRG/ANEEL n. 02/2001, de 15/01/2001. Esta influência afeta a operação diminuindo os níveis dos reservatórios, já que a geração térmica é adiada para o final do período de planejamento.

Adotou-se como início de todos os períodos o mês de maio, por ser o início do período seco na bacia hidrográfica em questão. Esta escolha justifica-se pelo fato de que, uma vez que os volumes iniciais dos reservatórios do sistema devem ser fornecidos, é mais simples iniciar os estudos a partir de um mês onde se sabe que tais reservatórios devem estar cheios. Conseqüentemente, como final, adotou-se o mês de abril, final do período de afluências mais elevadas. As afluências naturais aos reservatórios em toda pesquisa foram retiradas do arquivo de vazões do Sistema Brasileiro.

Todos os testes realizados foram exploratórios, com objetivos de se verificar o comportamento na prática do método desenvolvido.

Para a aplicação do algoritmo proposto, os testes foram agrupados e são apresentados, em cinco Estudos mostrando situações diferentes que vão evoluindo em complexidade. O Estudo I, trabalha com um sistema de 7 usinas em cascata, abrangendo o período do histórico de afluências, de 1947 a 1949. No Estudo II, o período de afluências é de 1953 a 1955. Já no Estudo III, o período de afluências é de 1981 a 1983 . O Estudo IV, é mais complexo pois o sistema teste será composto por 19 usinas à reservatório e no Estudo V, testes com 35 usinas. 


\subsection{Estudo I}

O algoritmo proposto foi aplicado em um sistema teste composto por 7 usinas, conforme apresentado na Figura 4.9, onde foram utilizadas vazões afluentes referentes ao período do histórico de 1947 a 1949. Esse período é considerado um período de afluência média.

O objetivo deste teste é mostrar o desempenho do método proposto em uma situação operativa mais real, diferente da relativamente suave e comportada apresentada pelas afluências iguais à MLT. As trajetórias de volumes definidas pelo PNL e AGs são apresentadas nas Figuras 6.2 e 6.3 .

Quando adotado o período histórico das afluências, o reservatório não terá mais um comportamento uniforme, pois precisa suprir a irregularidade das afluências no período de planejamento e atender a demanda prevista, definindo assim um ciclo de operação anual que não mais se repitirá em anos subseqüentes.

Os comportamentos dos reservatórios determinados pelos dois algoritmos PNL e AGs, são mostrados nas Figuras 6.2 e 6.3.

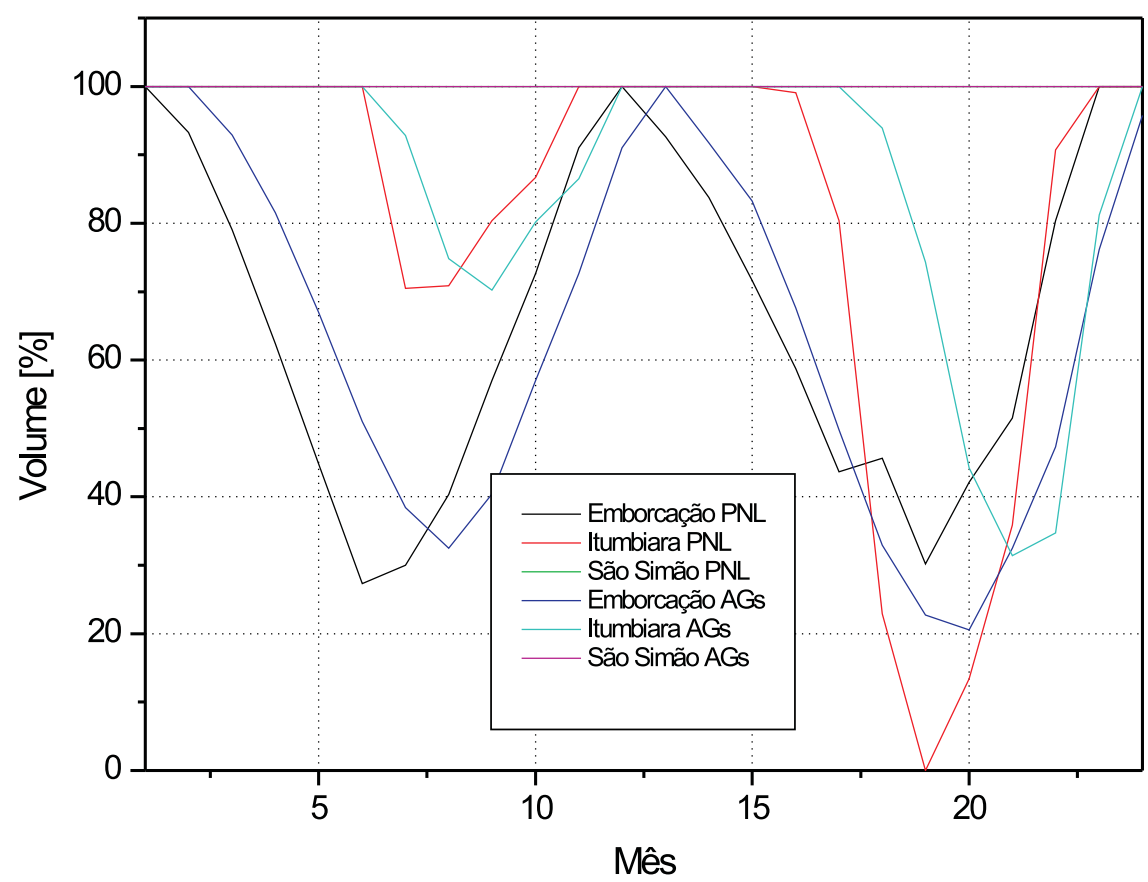

Figura 6.2: Estudo I - Trajetória ótima de volume no período de 1947 a 1949 


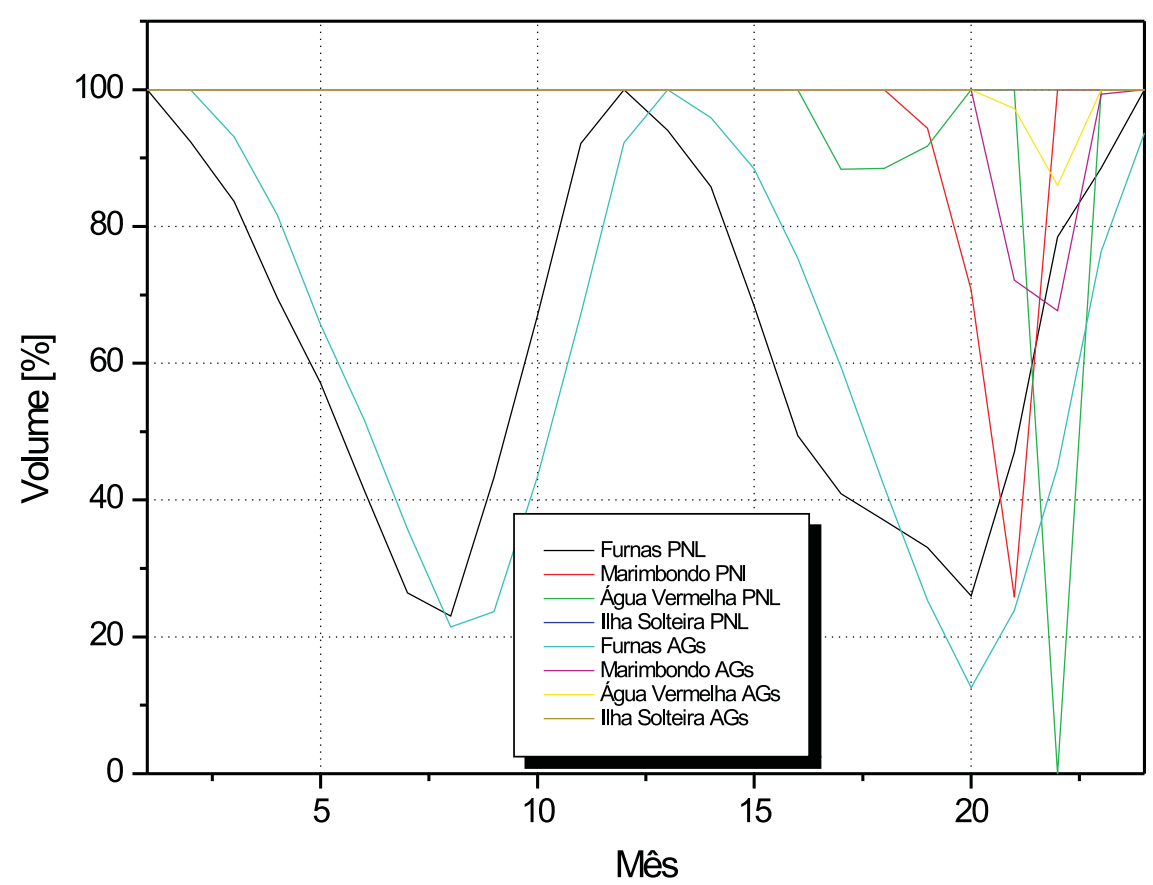

Figura 6.3: Estudo I - Trajetória ótima de volume no período de 1947 a 1949

Observe que, no primeiro ano de planejamento os reservatórios tiveram comportamentos semelhantes. Já no segundo ano, ocorreu um esvaziamento brusco em alguns reservatórios, o que pode ser visto mais claramente nas usinas de Itumbiara, Marimbondo e Água Vermelha, principalmente no cronograma de operação determinado pela PNL.

Os AGs conseguiram suavizar esse esvaziamento, apresentando uma curva um pouco mais comportada. Isso motiva a utilização dos AGs em situações operativas onde o PNL não consegue convergir satisfatoriamente, seja por deficiência do próprio método ou da técnica utilizada para solucionar o problema.

A geração hidráulica e a complementação térmica são apresentadas na Figura 6.4.

Observe que, o comportamento dos dois algoritmos foi bastante semelhante, mas a complementação térmica apresenta alguns picos fazendo com que o custo de operação seja maior, como citado anteriormente. 


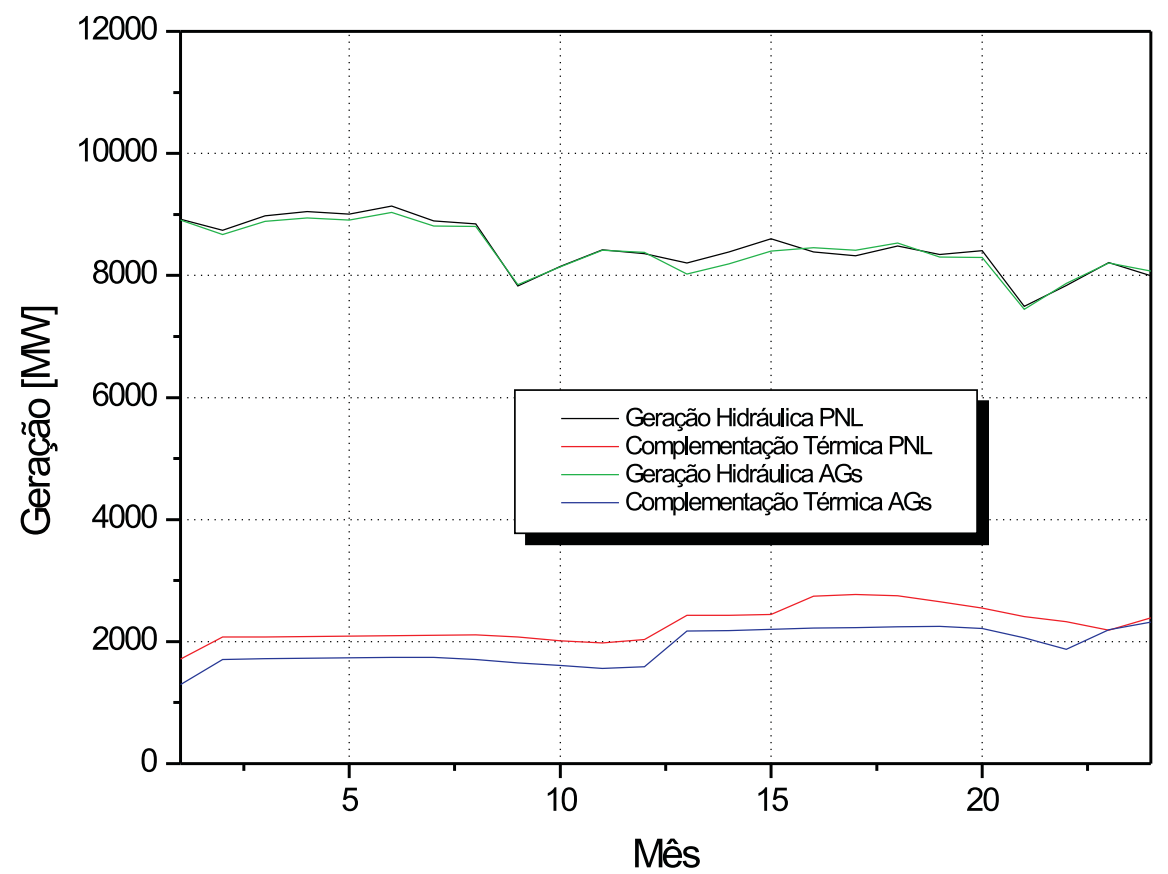

Figura 6.4: Estudo I - Complementação térmica para sete usinas em cascata (19471949)

\subsection{Estudo II}

Neste Estudo foi utilizada vazão afluente referente ao período mais seco do histórico, o chamado período crítico, que vai de 1953 a 1955.

Através das Figura 6.5 e 6.6, pode-se observar o comportamento dos reservatórios. Observe que, neste período de pouca chuva considerado um período seco, os AGs conseguiram captar sem dificuldades as características de operação das usinas e definiram um cronograma de operação semelhante ao PNL.

Essa característica de operação pode também ser observada nas curvas de geração apresentada na Figura 6.7, que confirma o bom desempenho do método proposto. 


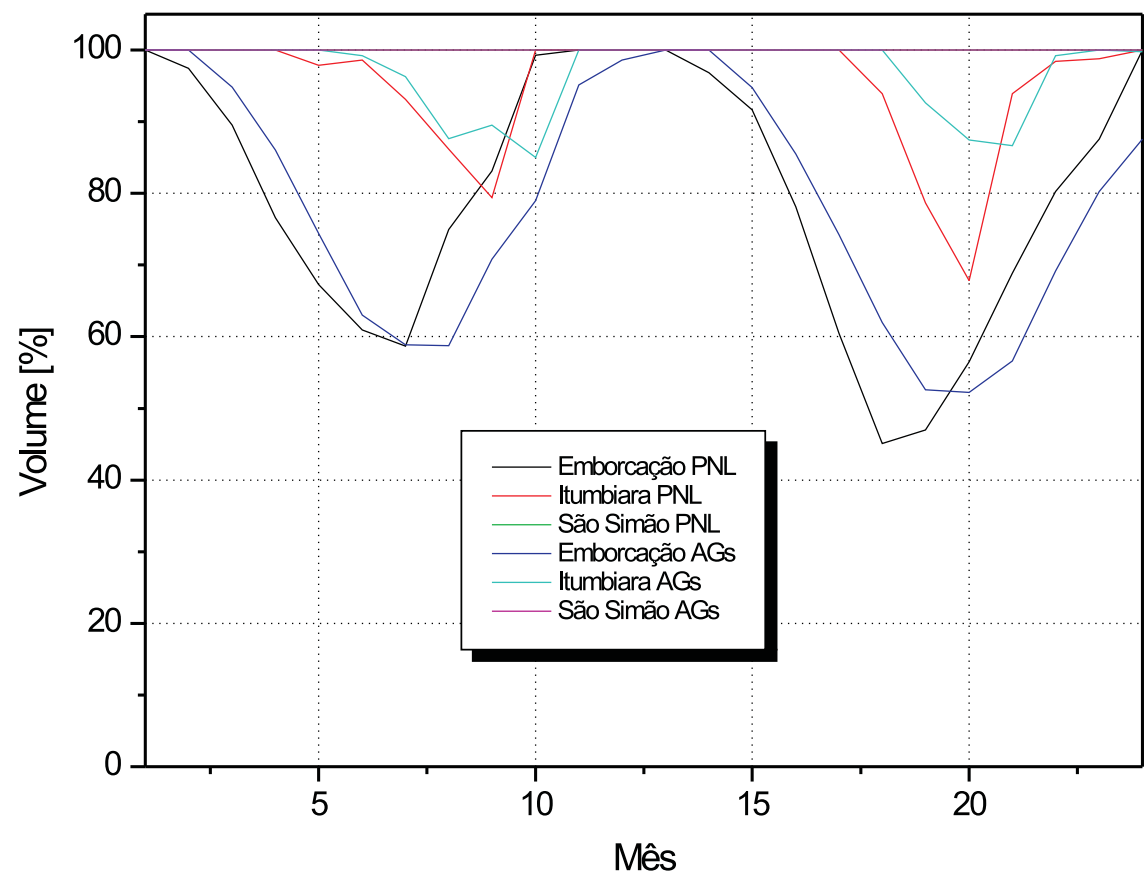

Figura 6.5: Estudo II - Trajetória ótima de volume no período de 1953 a 1955

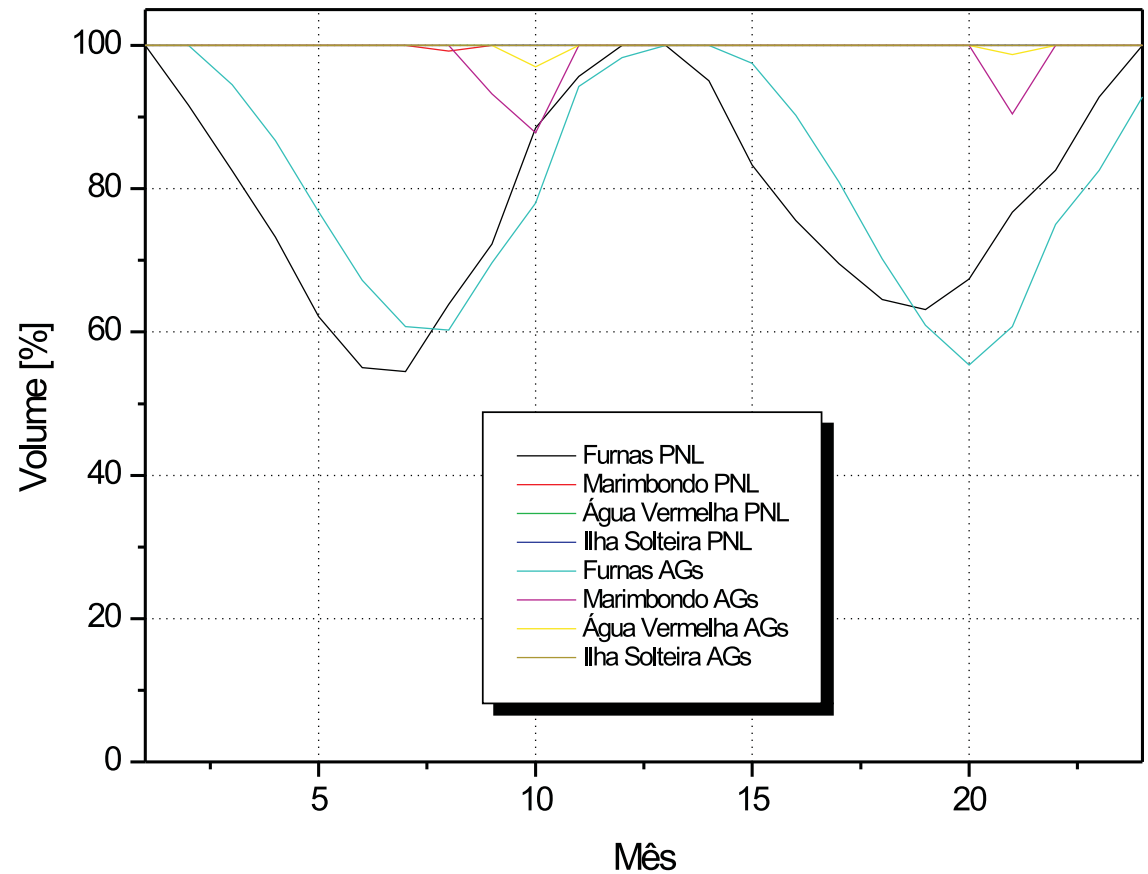

Figura 6.6: Estudo II - Trajetória ótima de volume no período de 1953 a 1955 


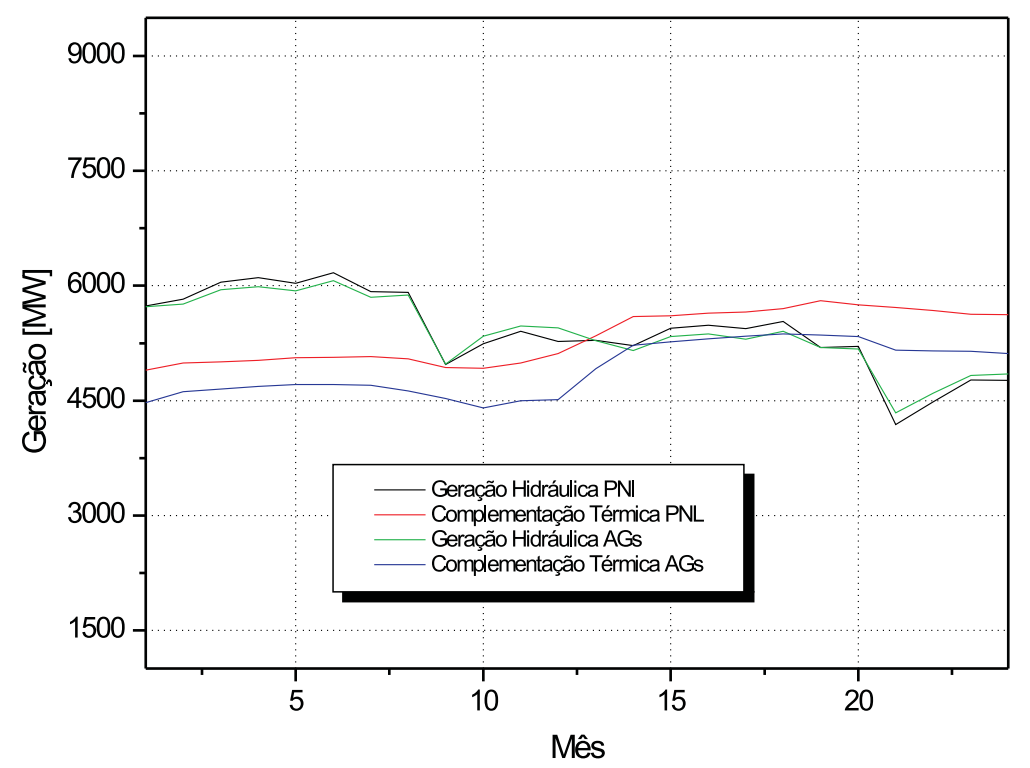

Figura 6.7: Estudo II - Complementação térmica para sete usinas em cascata (19531955)

\subsection{Estudo III}

O período do histórico utilizado vai de 1981 a 1983. Neste período as vazões afluentes foram altas proporcionando maior deplecionamento dos reservatórios e elevando os volumes ao final do horizonte, evitando o desperdício com vertimento no período das chuvas.

Neste caso, a complementação térmica foi nula, pois a demanda foi totalmente atendida pela geração hidráulica, como apresentado na Figura 6.8. Portanto, optou-se por apresentar apenas o gráfico da geração.

Os reservatórios, neste Estudo, operam conforme o período de afluência, deplecionando os seus volumes de forma a atender a demanda sem causar déficit no futuro, pois mantêm os reservatórios cheios ao final de cada horizonte de planejamento e no caso em que ocorrem chuvas em abundância, diminui o volume minimizando a geração térmica de forma confiável. Esse ciclo de operação anual foi também definido pelo AGs. 


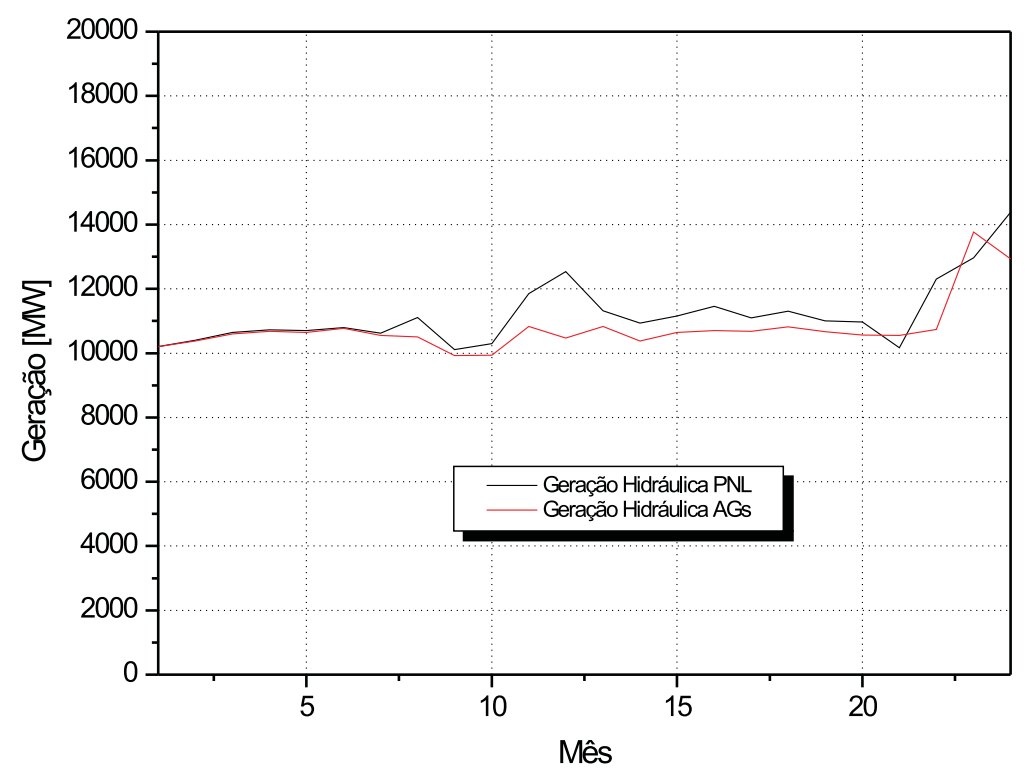

Figura 6.8: Estudo III - Complementação térmica para sete usinas em cascata (19811983)

\subsection{Estudo IV}

Com objetivo de analisar o comportamento da operação das usinas hidroelétricas e a solução ótima determinada pelos Algoritmos Genéticos, realizou-se um estudo, adotando-se uma situação mais complexa de operação, onde mais usinas hidroelétricas instaladas em cascatas diferentes do Sistema Sudeste Brasileiro foram utilizadas, conforme apresentado na Figura 6.1.

As usinas envolvidas nesse teste são a reservatório, ou seja, têm a capacidade de acumular água na época das cheias para uso na época de estiagem, dispondo assim de uma vazão firme maior que a vazão mínima natural e estão situadas em cascatas diferentes. Os dados das usinas são apresentados no Apêndice B.

\subsubsection{Teste 1 - Afluência igual a MLT}

Para execução do teste 1, nesse Estudo, foram utilizadas as vazões afluentes iguais à MLT, com volumes iniciais e finais iguais a $100 \%$ do volume útil, um horizonte de planejamneto de 24 meses, demanda igual à potência instalada e mercado variando sazonalmente ao longo de cada ano. 
Os gráficos de cada cascata serão traçados separadamente para melhor análise dos resultados.

As curvas de volumes definidas pelos AGs são mostradas nas Figuras 6.9 a 6.15 .

Observe que mesmo em um sistema muito mais complexo o algoritmo proposto consegue captar as características de operação das usinas. Por exemplo, as usinas de Emborcação, Nova Ponte, Furnas, Caconde, e as demais usinas a montante se encarregam da regulação do sistema oscilando no seus volumes.

No caso das usinas de jusante, São Simão, Água Vermelha, Ilha Solteira, Itaipu e as demais, espera-se que seus reservatórios permaneçam com $100 \%$ do volume útil, ou seja, não variem seus volumes. Isso só não ocorreu na cascata do rio Tietê e Paranapanema, pois as usinas de Três Irmãos e Capivara variaram os seus volumes.

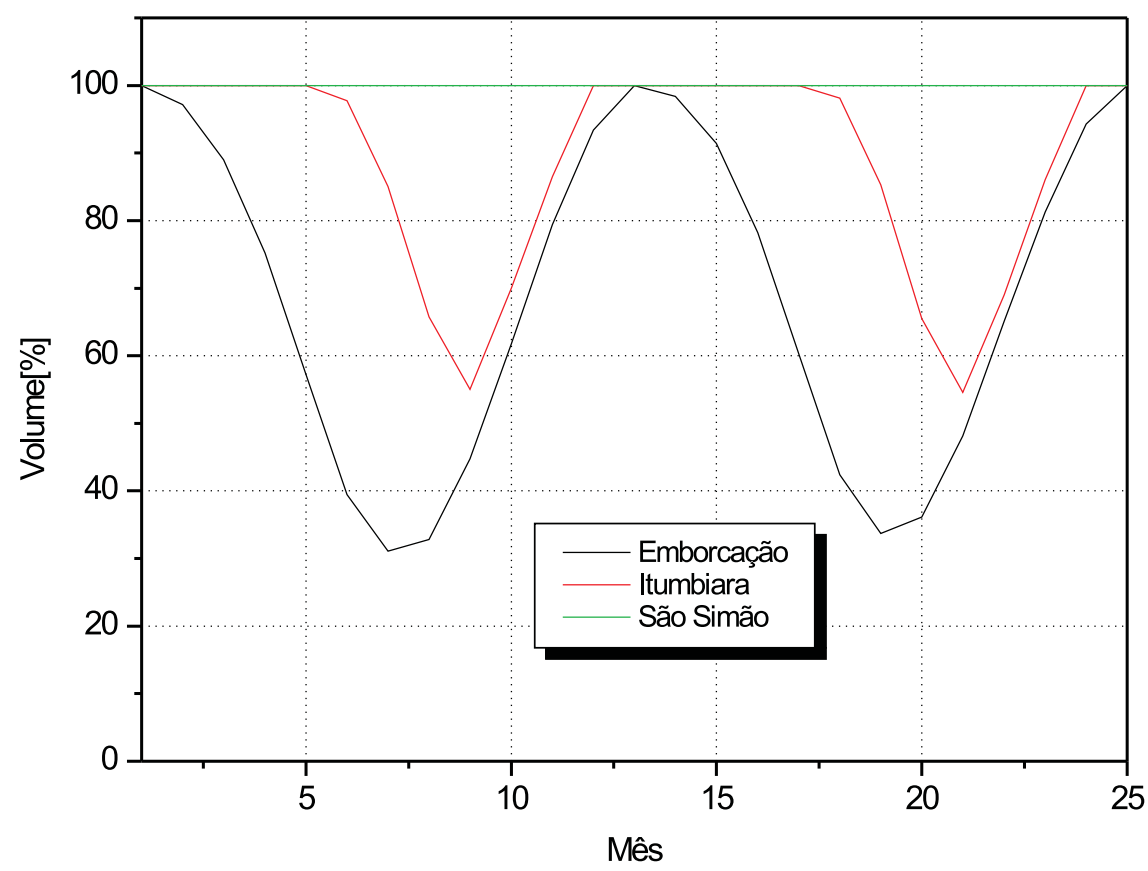

Figura 6.9: Estudo IV - Trajetória ótima de volume da cascata do rio Paranaiba 


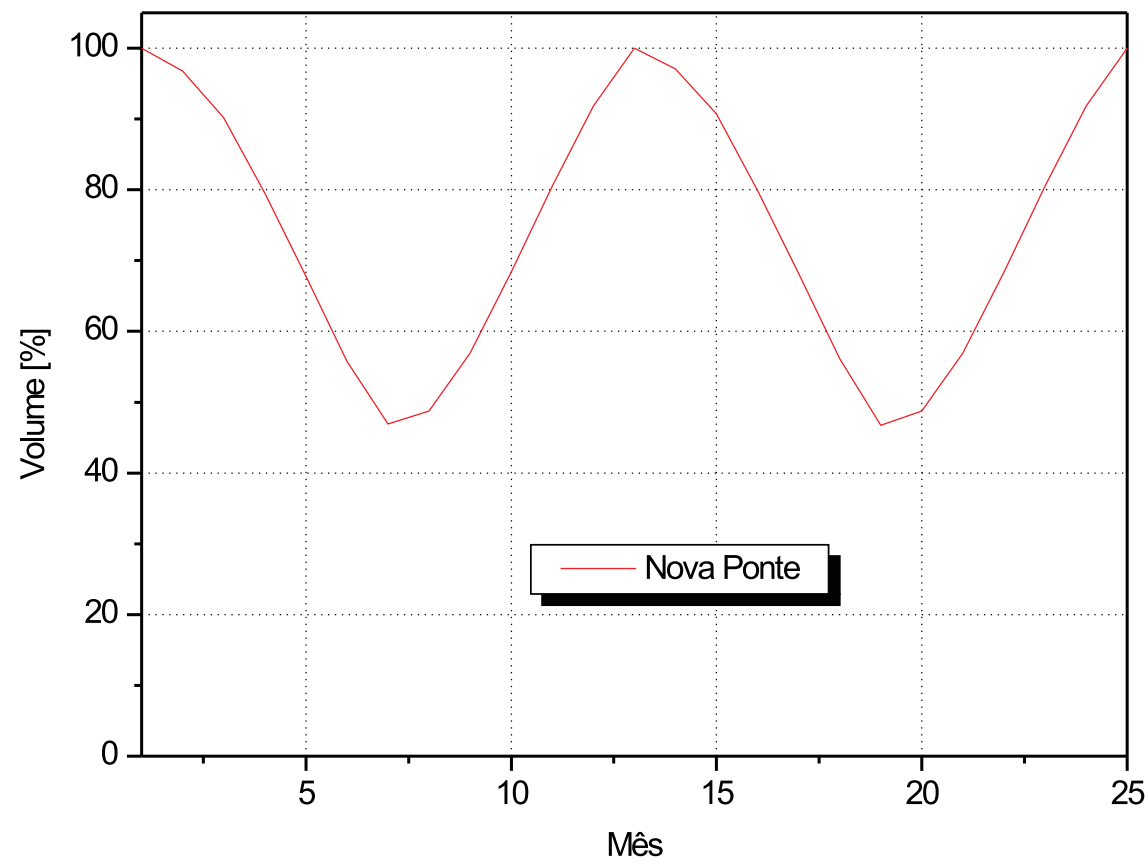

Figura 6.10: Estudo IV - Trajetória ótima de volume da cascata do rio Araguari

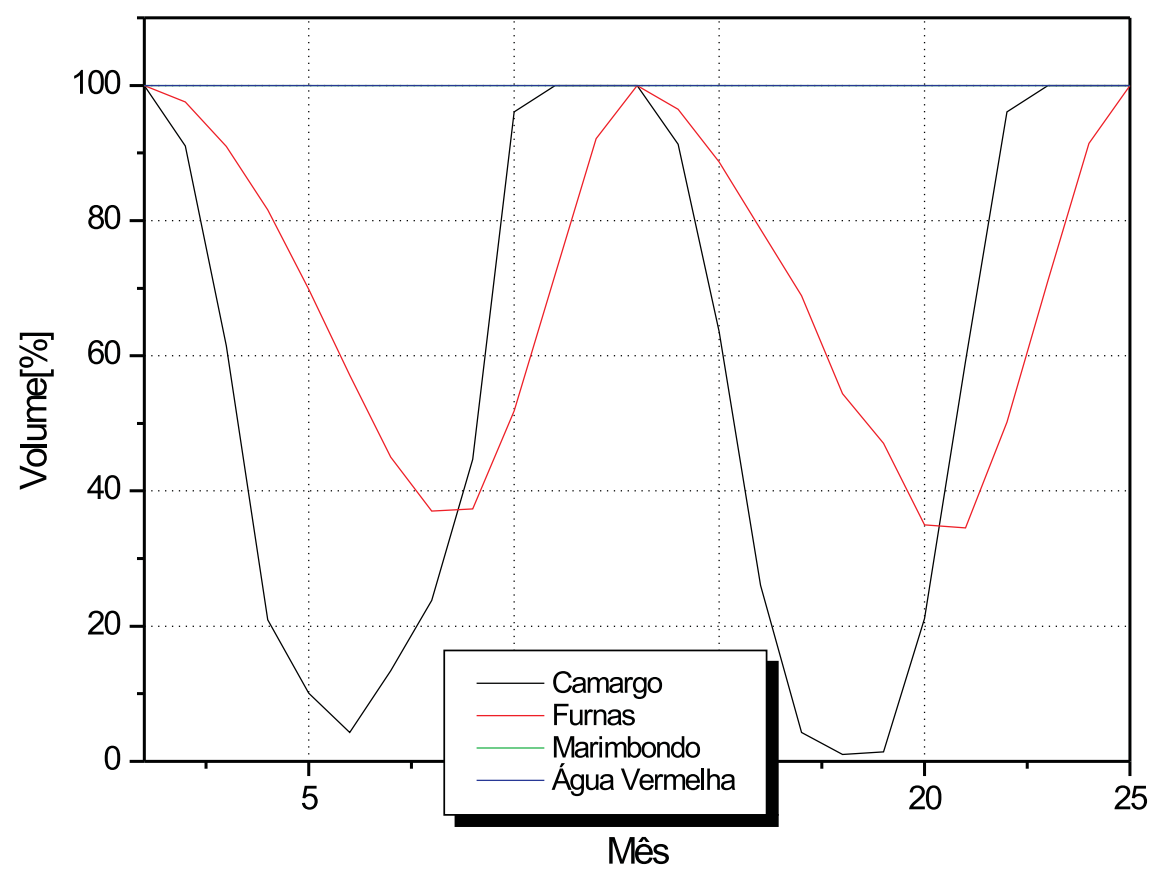

Figura 6.11: Estudo IV - Trajetória ótima de volume da cascata do rio Grande 


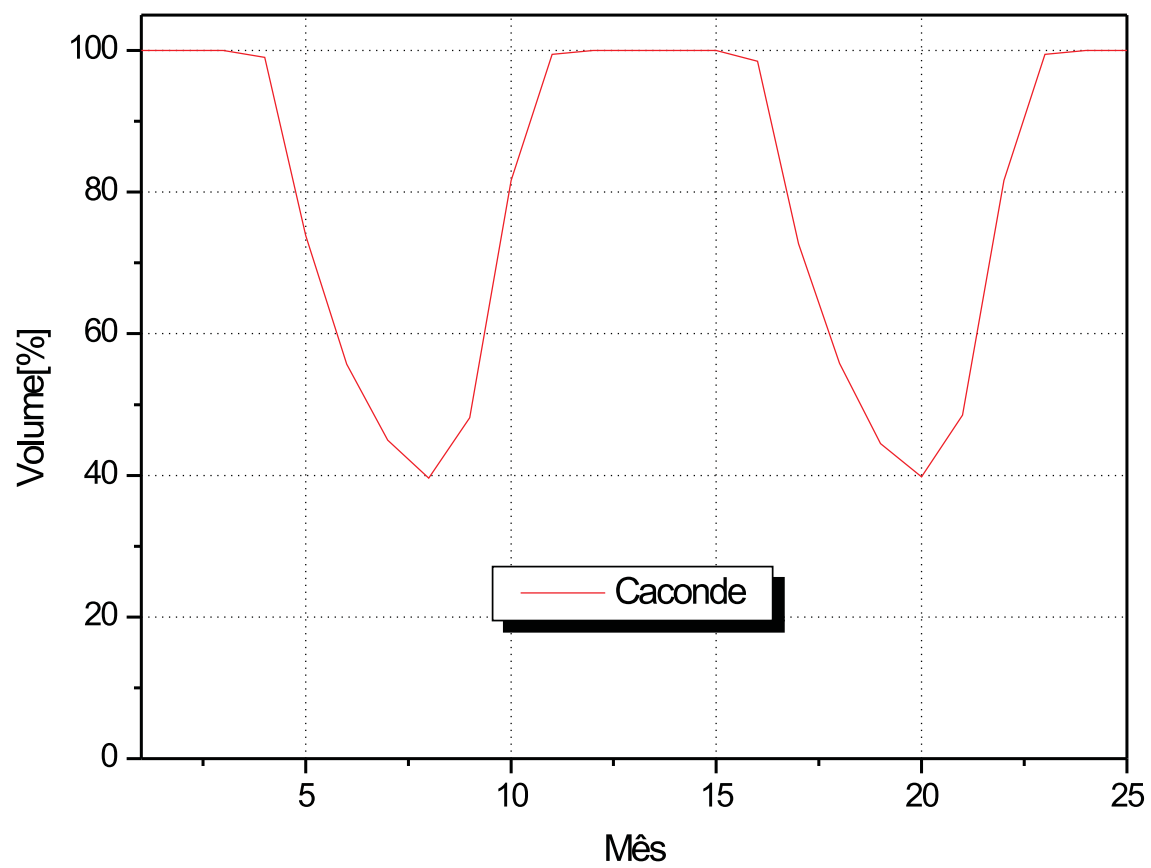

Figura 6.12: Estudo IV - Trajetória ótima de volume da cascata do rio Pardo

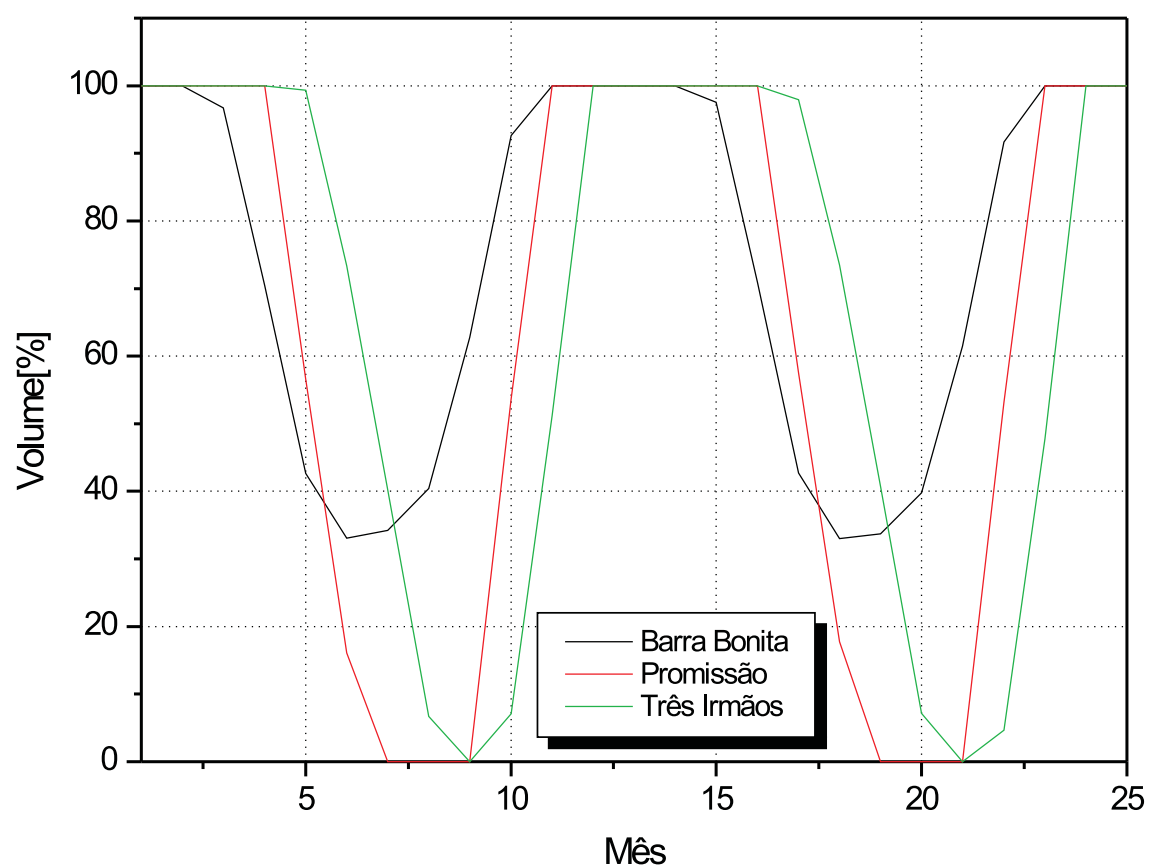

Figura 6.13: Estudo IV - Trajetória ótima de volume da cascata do rio Tietê 


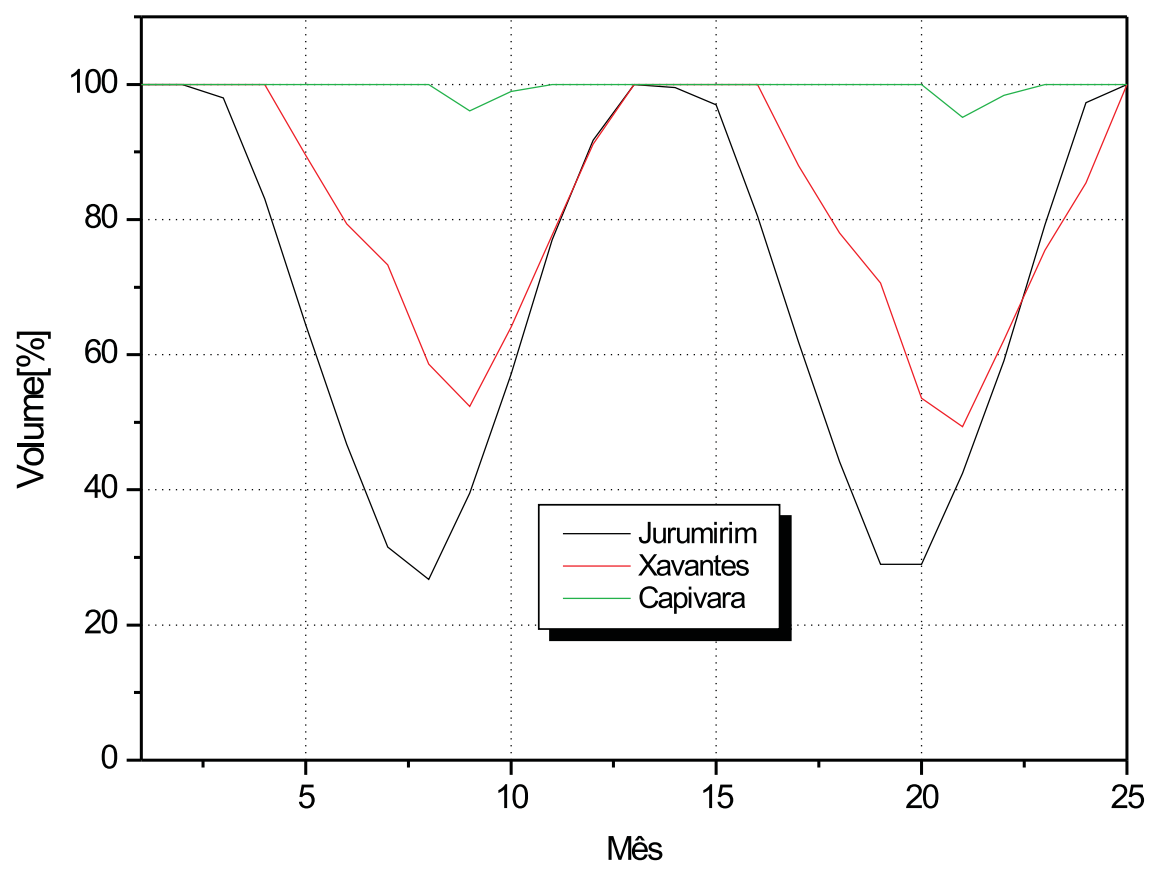

Figura 6.14: Estudo IV - Trajetória ótima de volume da cascata do rio Paranapanema

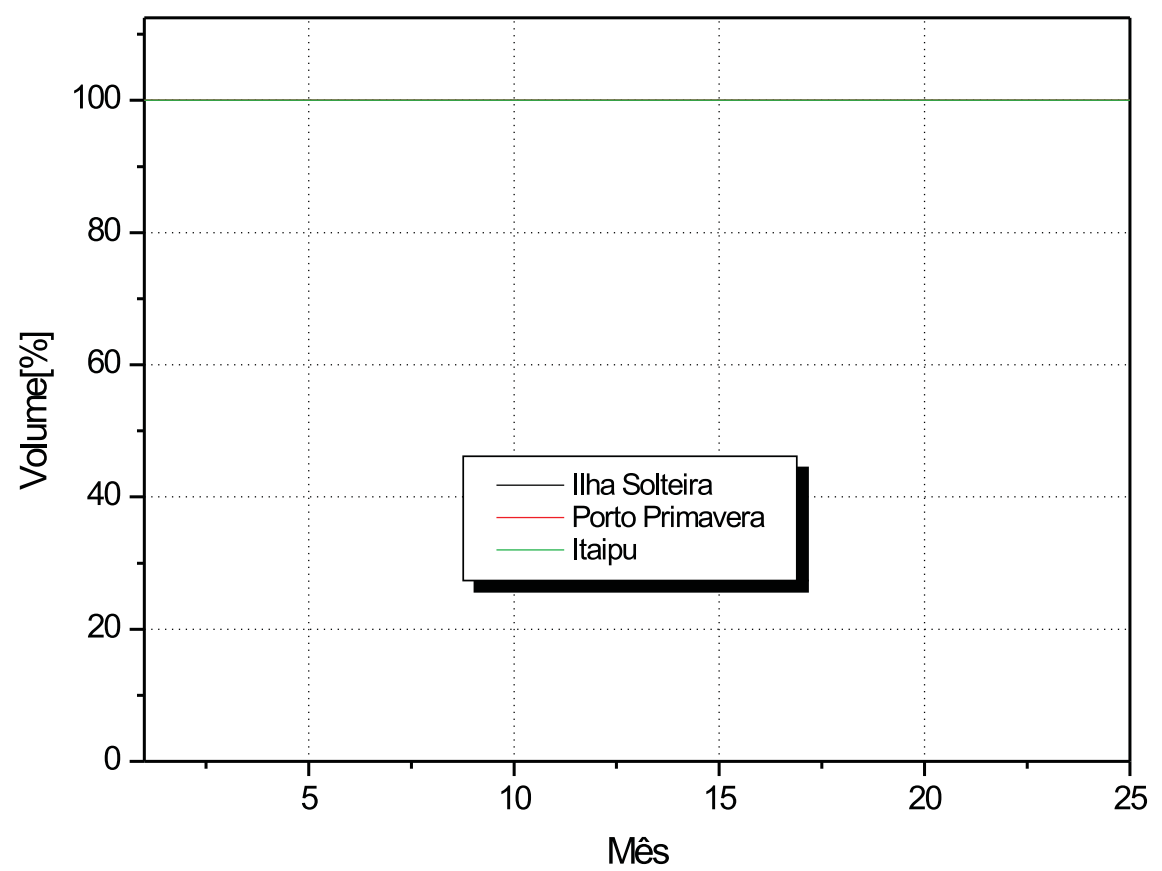

Figura 6.15: Estudo IV - Trajetória ótima de volume da cascata do rio Paraná

Como mostrado na Figura 6.16, a geração hidráulica total do sistema repetiu-se no segundo ano devido à utilização da MLT, confirmando o bom desempenho do algoritmo. 
A complementação térmica obtida pelos AGs é quase constante ao longo do período de planejamento, indicando um custo de operação menor, pois este custo é dado por uma função com crescimento exponencial. Portanto, quanto mais uniforme menor o seu valor.

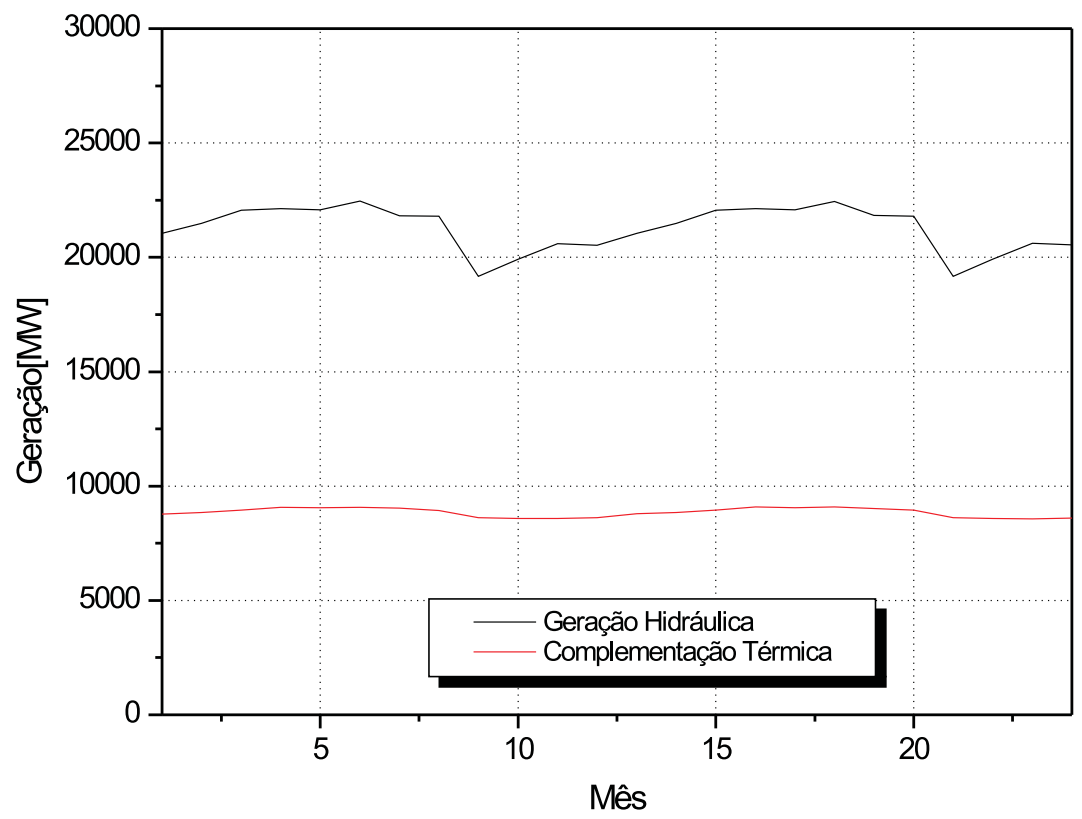

Figura 6.16: Estudo IV - Geração Hidráulica e Complementação Térmica das usinas a reservatório do Sistema Sudeste

\subsubsection{Teste 2 - Afluência igual a $80 \%$ da MLT}

Na Figura 6.17, são mostradas as trajetórias ótimas de algumas usinas pertencentes ao Sistema Sudeste com afluência igual a $80 \%$ da MLT, com objetivo de verificar o comportamento do algoritmo proposto nesta condição de operação diferente da fornecida pela MLT. Mas vale lembrar, que as afluências são iguais nos dois anos.

A Figura 6.18, apresenta a geração determinada para o sistema. Pode-se verificar através da curva de complementação térmica que o algoritmo desenvolvido consegue sem dificuldade obter uma operação quase uniforme ao longo do período de dois anos, o que acarreta em um menor custo de operação. 


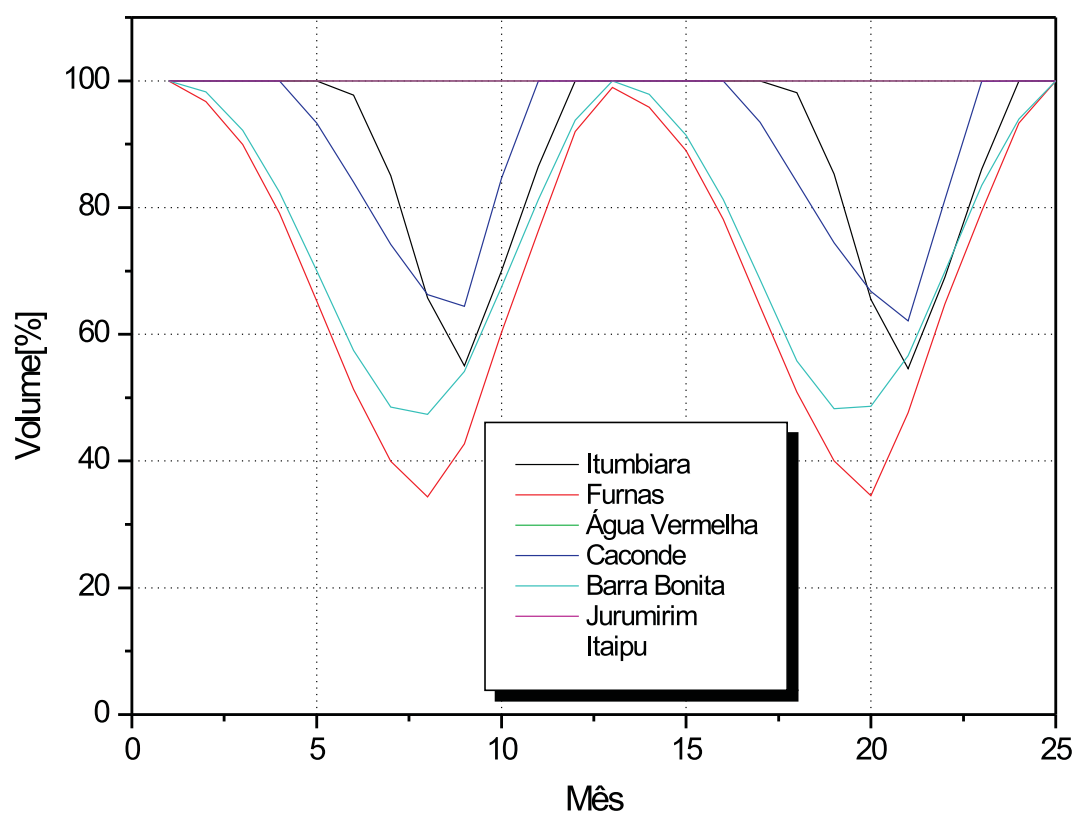

Figura 6.17: Estudo IV - Trajetória ótima de volume de algumas usinas do Sistema Sudeste com afluência igual a $80 \%$ da MLT

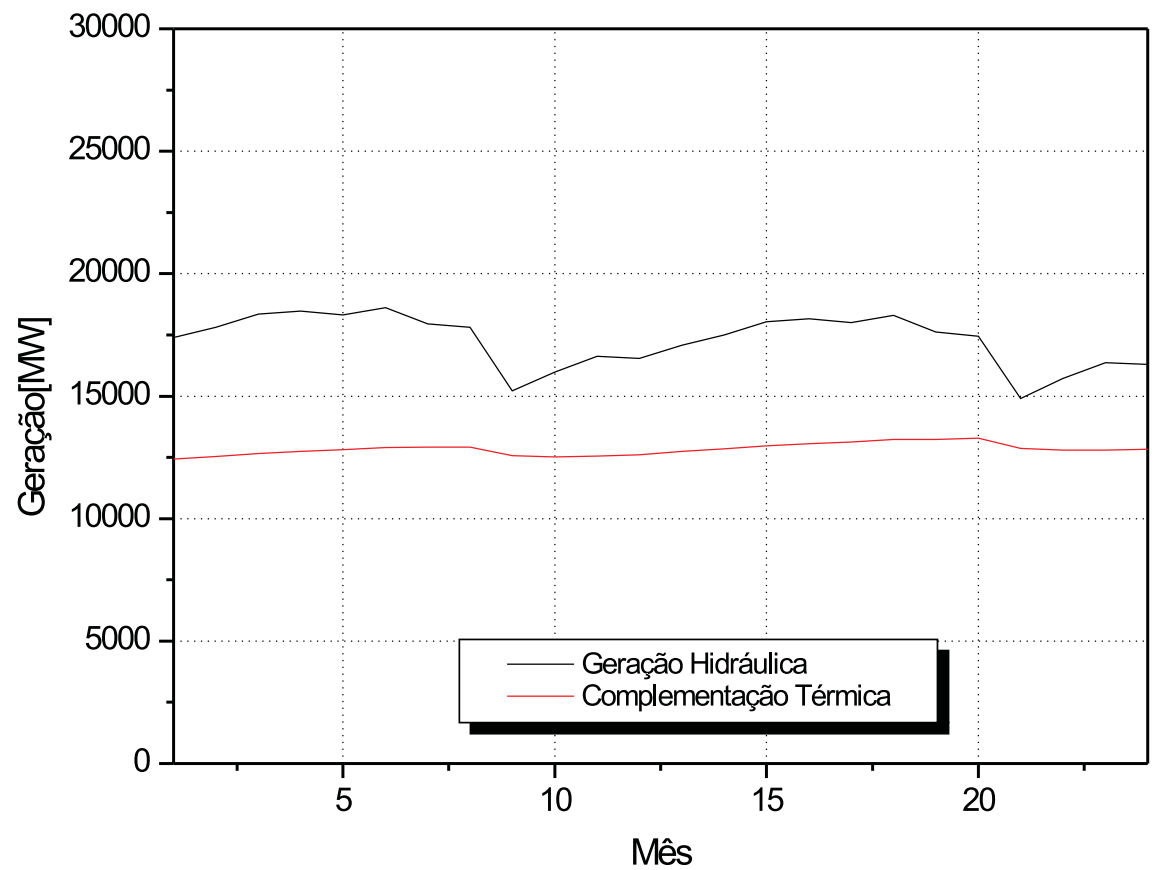

Figura 6.18: Estudo IV - Geração Hidráulica e Complementação Térmica das usinas a reservatório do Sistema Sudeste com afluência igual a $80 \%$ da MLT 


\subsubsection{Teste 3 - Afluência igual ao período do histórico de 1947 a 1949}

Quando adotado o período histórico das afluências o reservatório não terá mais um comportamento uniforme pois precisa suprir a irregularidade das afluências no período de planejamento, atender a demanda prevista e definir um ciclo de operação anual, conforme apresentado na Figura 6.19. A geração hidráulica e a complementação térmica são apresentadas na Figura 6.20 .

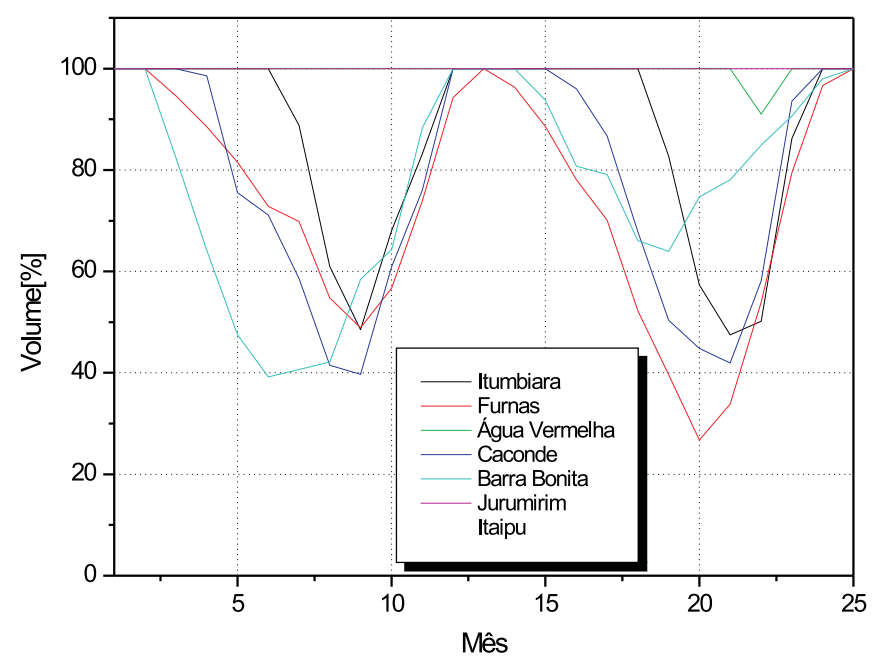

Figura 6.19: Estudo IV - Trajetória ótima de volume no período de 1947 a 1949

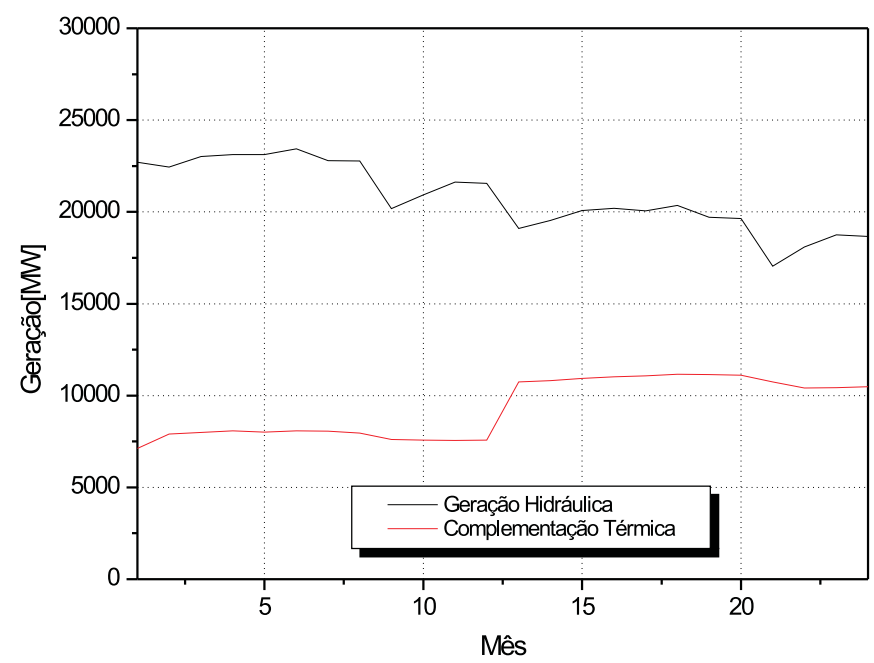

Figura 6.20: Estudo IV - Geração Hidráulica e Complementação Térmica das usinas a reservatório do Sistema Sudeste no período de 1947 a 1949 


\subsubsection{Teste 4 - Afluência igual ao período do histórico de 1953 a 1955}

Neste teste, foi utilizada vazão afluente referente ao período mais seco do histórico, o chamado período crítico, que vai de 1953 a 1955.

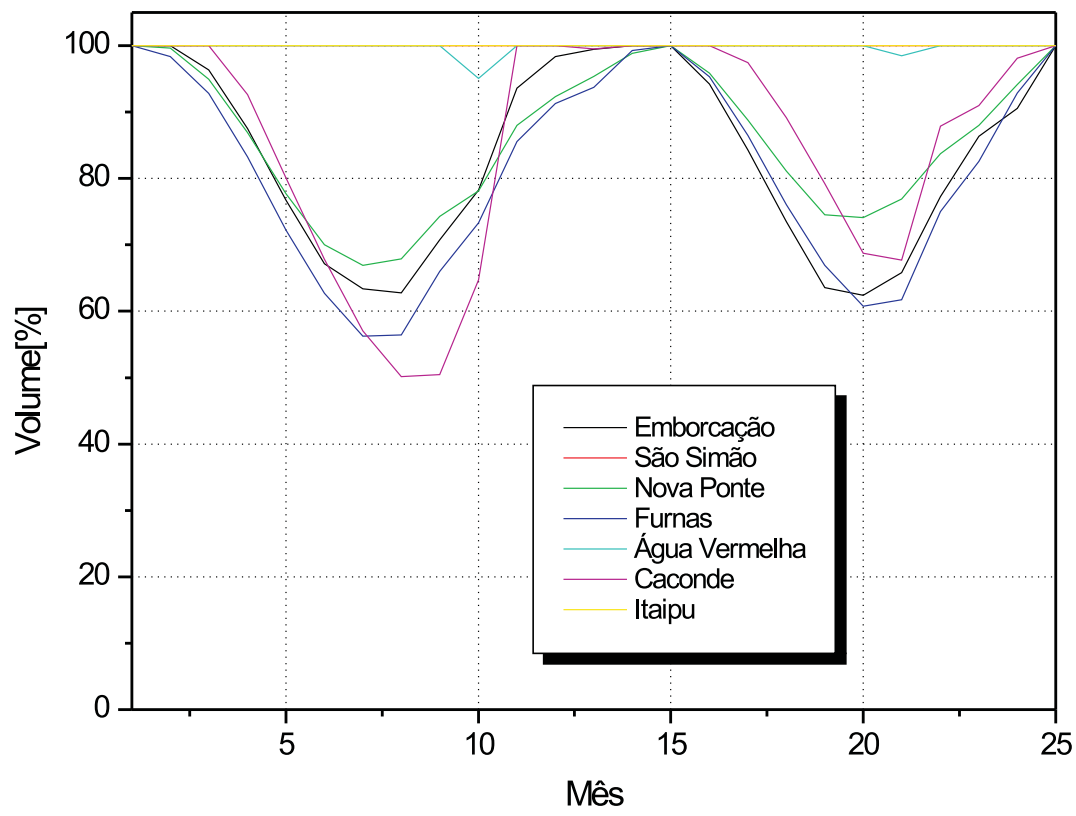

Figura 6.21: Estudo IV - Trajetória ótima de volume no período de 1953 a 1955

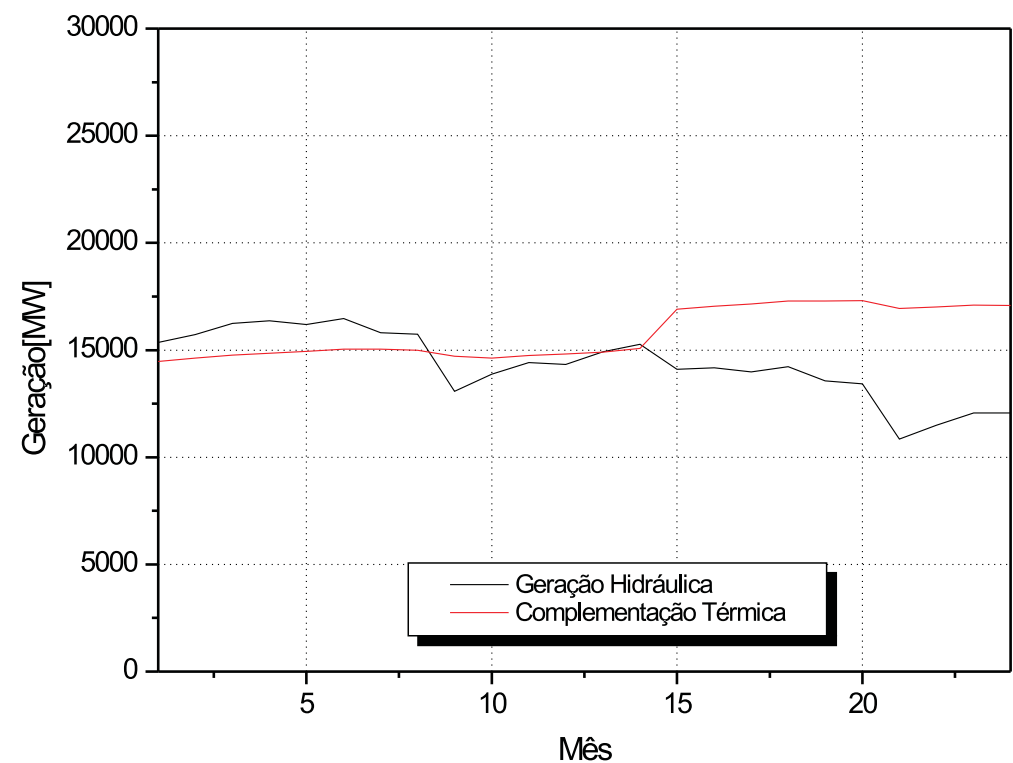

Figura 6.22: Estudo IV - Geração Hidráulica e Complementação Térmica das usinas a reservatório do Sistema Sudeste no período de 1953 a 1955 
O bom desempenho do algoritmo proposto mais uma vez é evidenciado, pois mesmo em um período seco os AGs conseguiram captar sem dificuldades as características de operação das usinas e definiu um cronograma de operação neste período.

\subsection{Estudo V}

Este último Estudo, apresenta uma aplicação do algoritmo proposto em um sistema teste composto por 35 usinas hidroelétricas, abrangendo grande parte do Sistema Sudeste Brasileiro, sendo utilizadas usinas a reservatório e a fio d'água, conforme apresentado na Figura 6.1. Com uma potência instalada total de 36271 MW.

Um subsistema incluindo somente as usinas a reservatório foi testado e apresentado no Estudo anterior, tendo-se posteriormente acrescentado as usinas a fio d'água, com objetivo de se verificar as interferências que poderiam surgir para o algoritmo proposto, principalmente quanto ao crescimento do número de usinas, o que atestou a viabilidade do AGs em se operar com várias usinas.

O objetivo do Estudo V, foi o de analisar o comportamento do algoritmo desenvolvido e já testado em sistemas menores, em um grande e complexo sistema com muitas usinas de grande porte, interligadas em paralelo e em cascata, com dados reais e características típicas das usinas brasileiras. Adotou-se também vazões afluentes distintas para melhor avaliação do algoritmo.

\subsubsection{Teste 1 - Afluência igual a MLT}

Observe nas Figuras 6.23 a 6.29 , que a introdução das usinas a fio-d'água não provocou alteração no comportamento do algoritmo proposto, pois os AGs conseguiu definir um cronograma de operação que se repetiu no segundo ano, diferentemente do PNL que em alguns caso não repetiu a mesma trajetória no segundo ano. 
Através da Figura 6.30, pode-se avaliar a geração hidráulica e a complementação térmica definida pelas duas técnica, quando se adota afluências iguais a MLT.

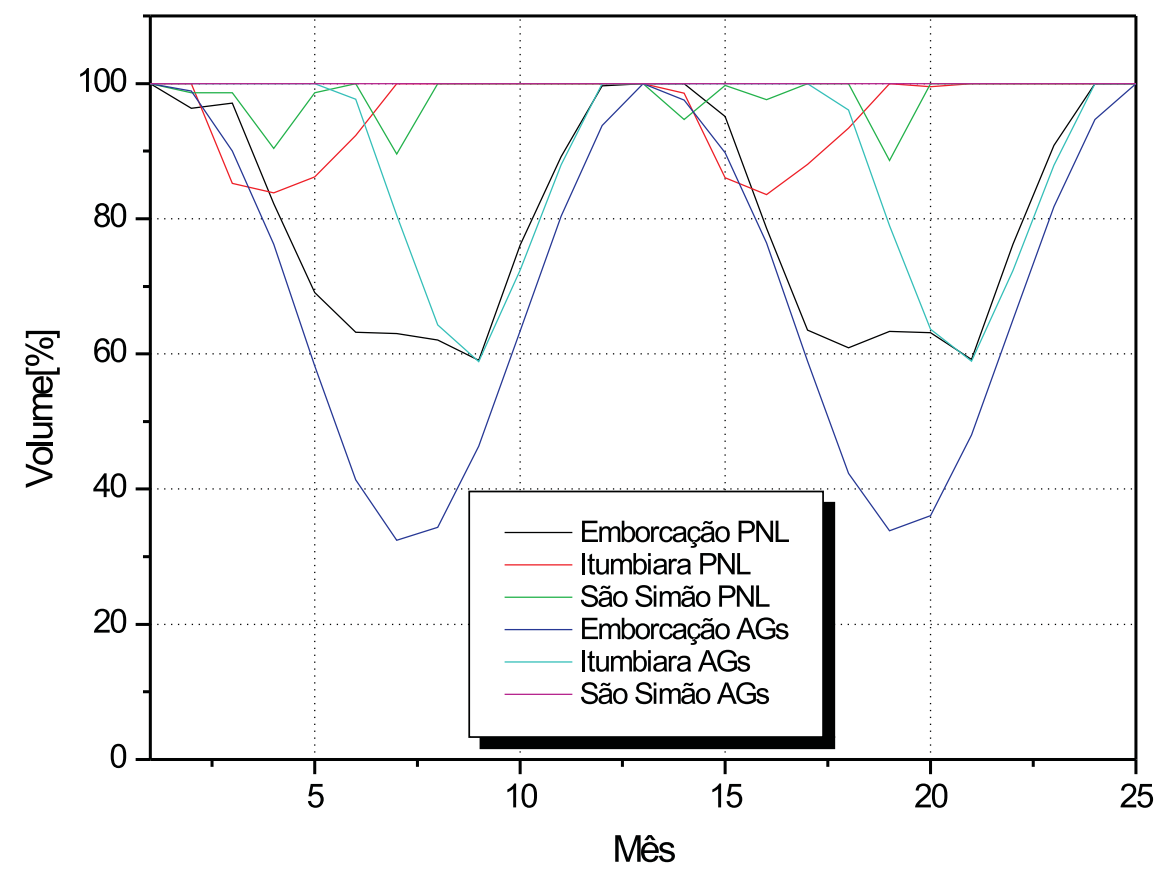

Figura 6.23: Estudo V - Trajetória ótima de volume da cascata do rio Paranaíba

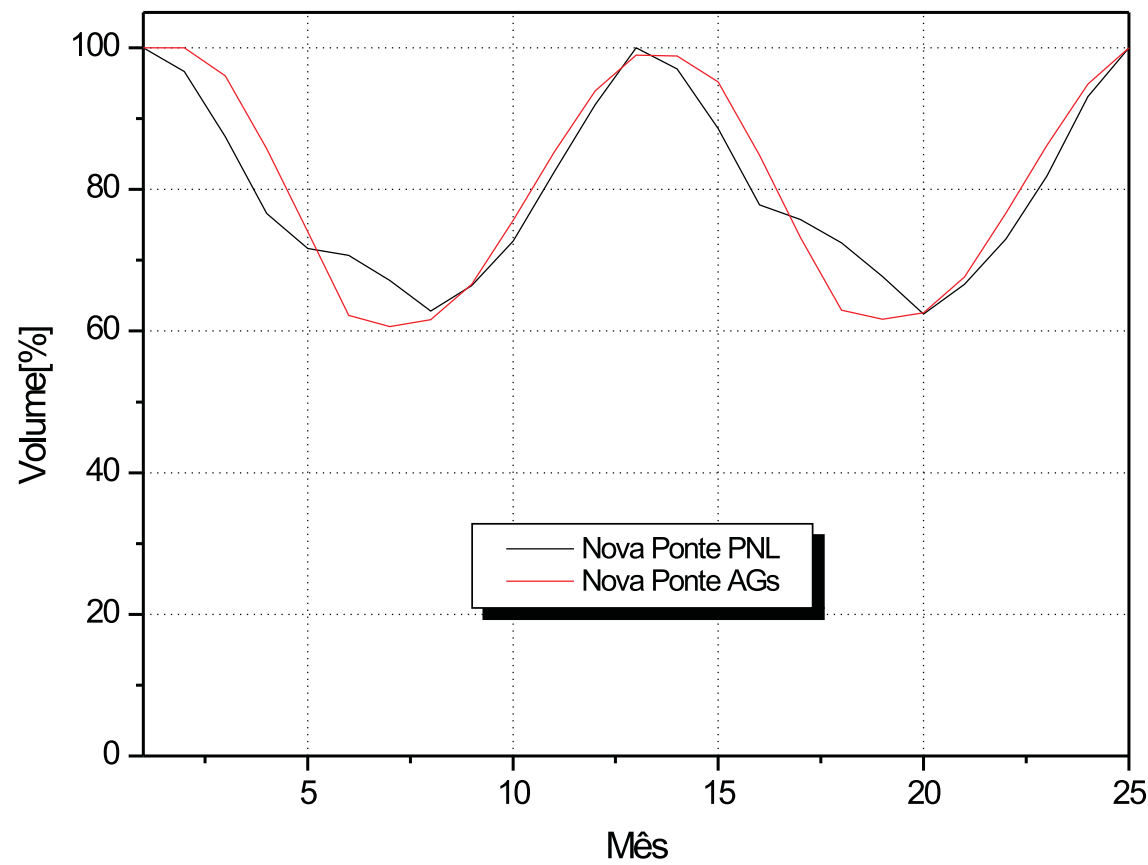

Figura 6.24: Estudo V - Trajetória ótima de volume da cascata do rio Araguari 


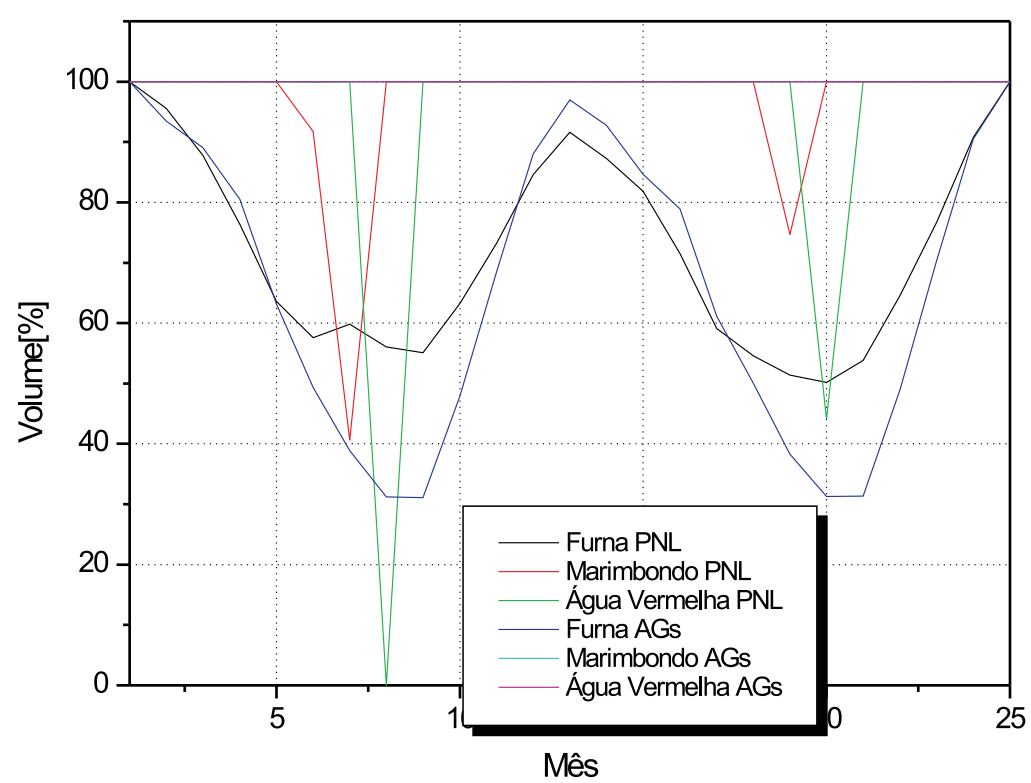

Figura 6.25: Estudo V - Trajetória ótima de volume da cascata do rio Grande

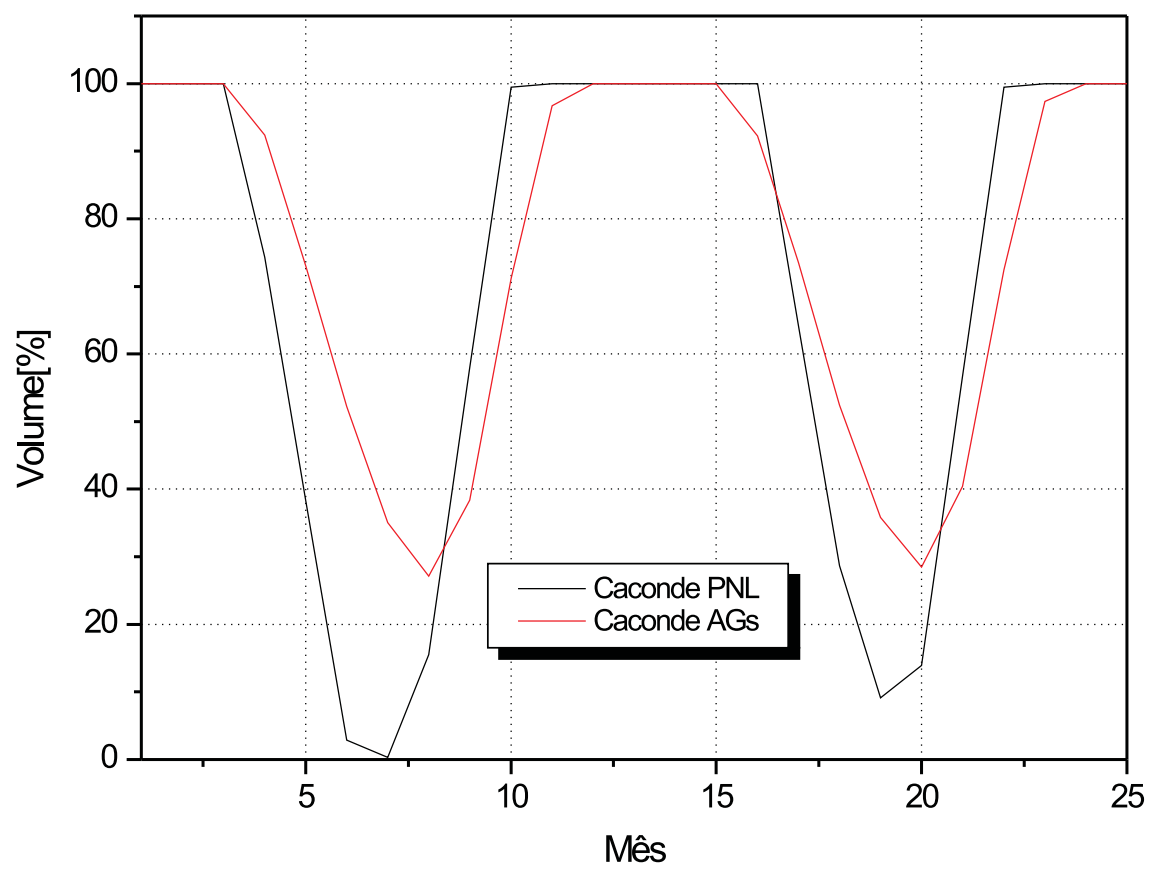

Figura 6.26: Estudo V - Trajetória ótima de volume da cascata do rio Pardo 


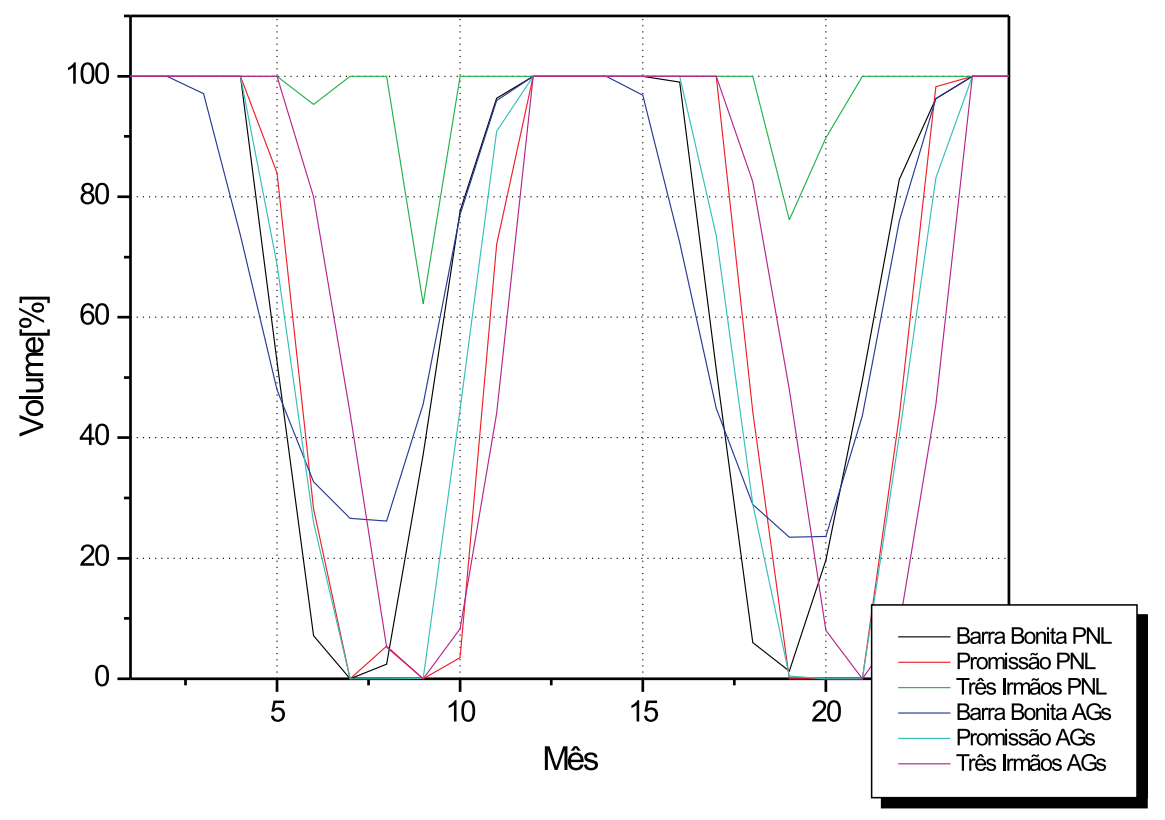

Figura 6.27: Estudo V - Trajetória ótima de volume da cascata do rio Tietê

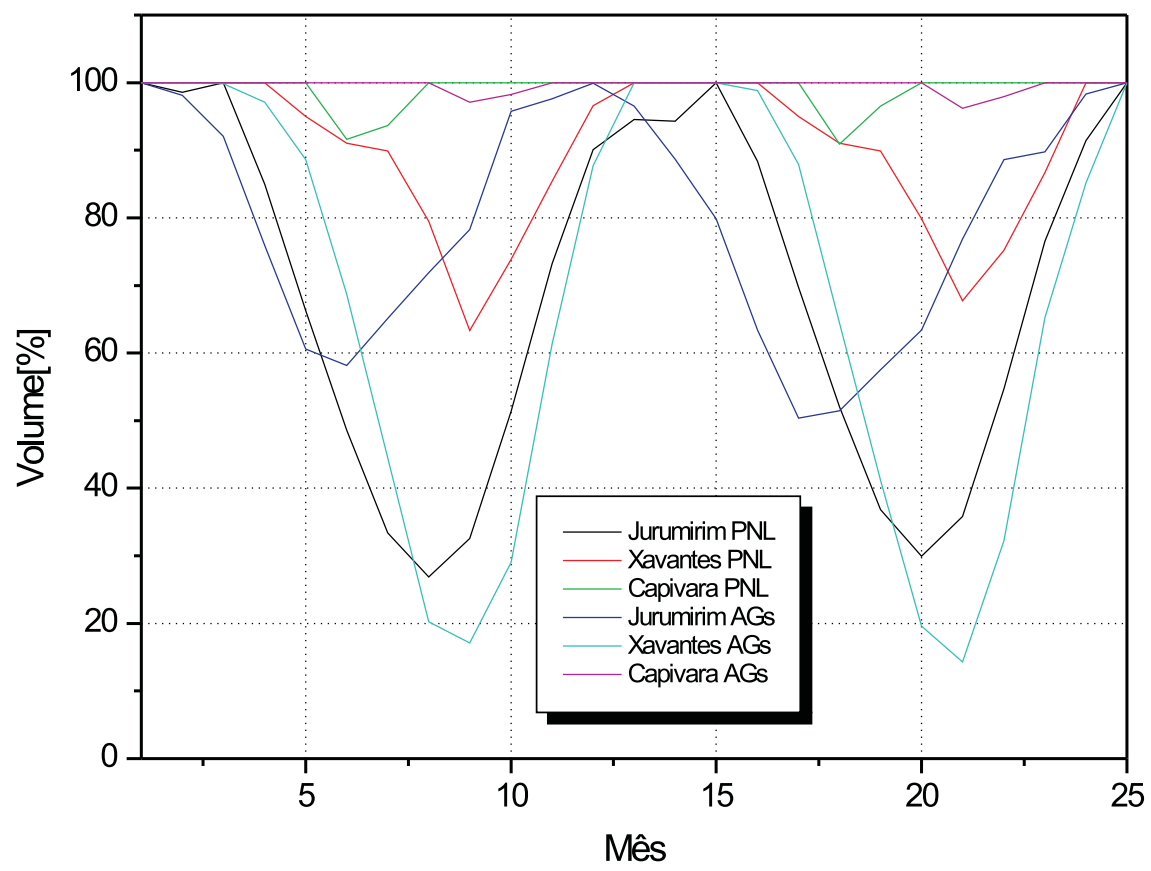

Figura 6.28: Estudo V - Trajetória ótima de volume da cascata do rio Paranapanema 


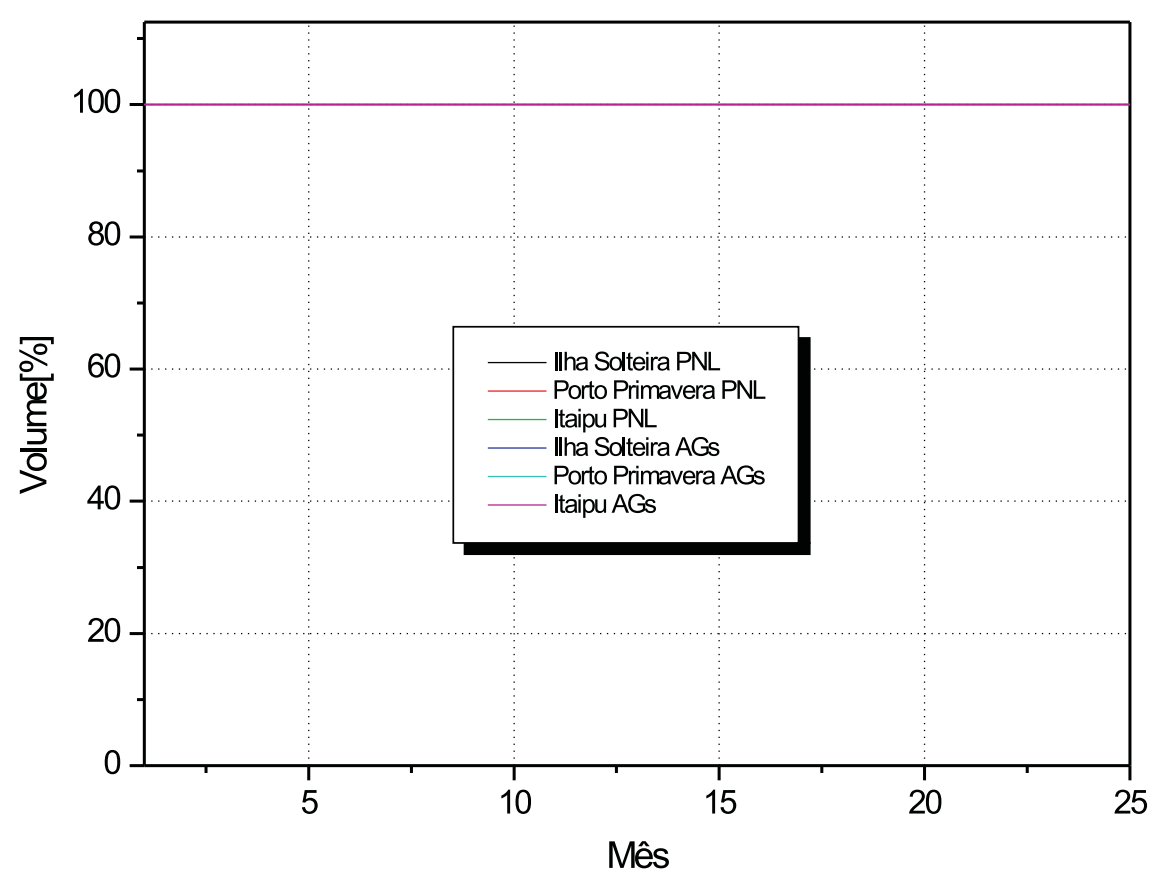

Figura 6.29: Estudo V - Trajetória ótima de volume da cascata do rio Paraná

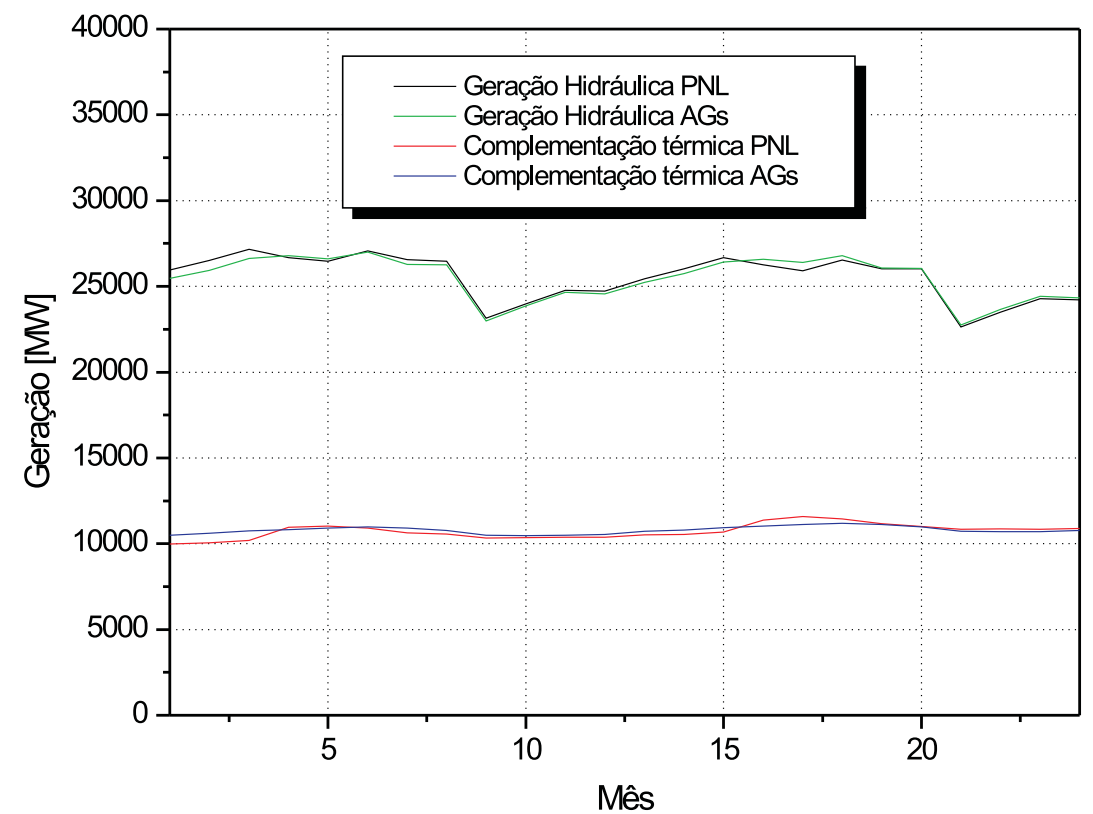

Figura 6.30: Estudo V - Geração Hidráulica e Complementação Térmica das usinas do Sistema Sudeste

\subsubsection{Teste 2 - Afluência igual a $80 \%$ da MLT}

Neste Teste, são adotadas vazões afluentes iguais a $80 \%$ da MLT com objetivo de se verificar o desempenho do algoritmo proposto com 35 usinas. Verifique através 
das Figuras 6.31 a 6.37 , que não houve grandes alterações no comportamento dos reservatórios.

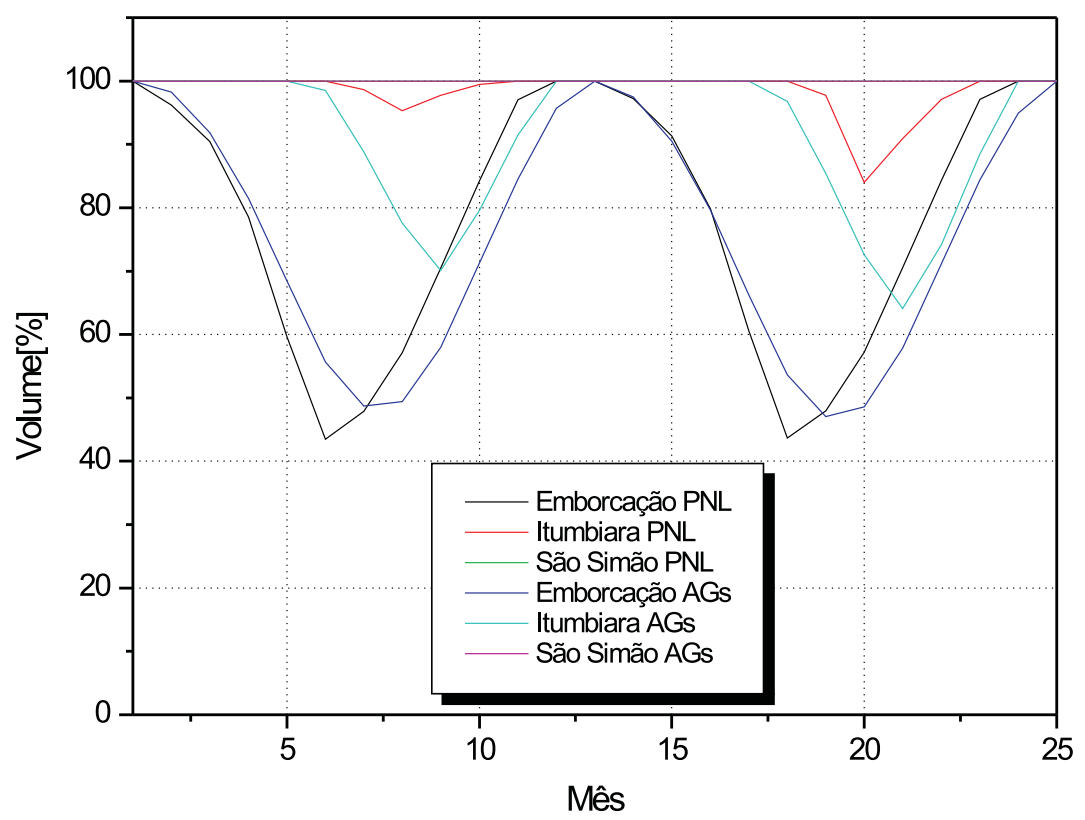

Figura 6.31: Estudo V - Trajetória ótima de volume da cascata do rio Paranaiba

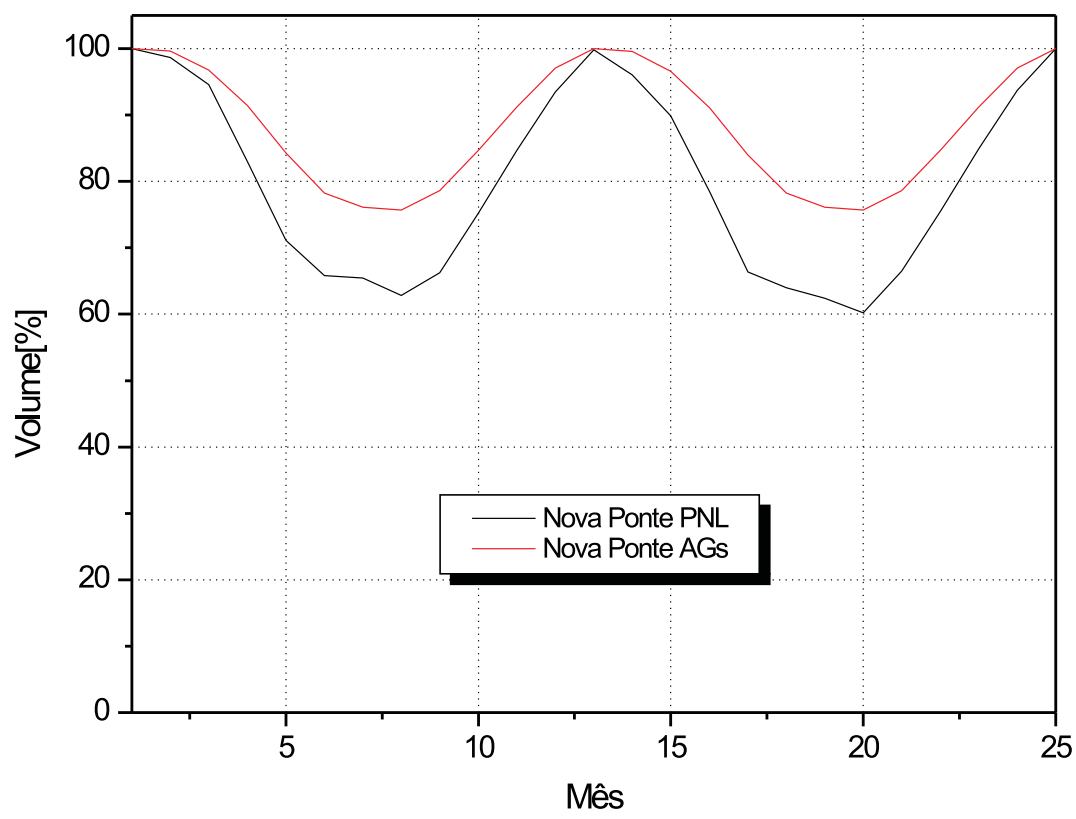

Figura 6.32: Estudo V - Trajetória ótima de volume da cascata do rio Araguari 


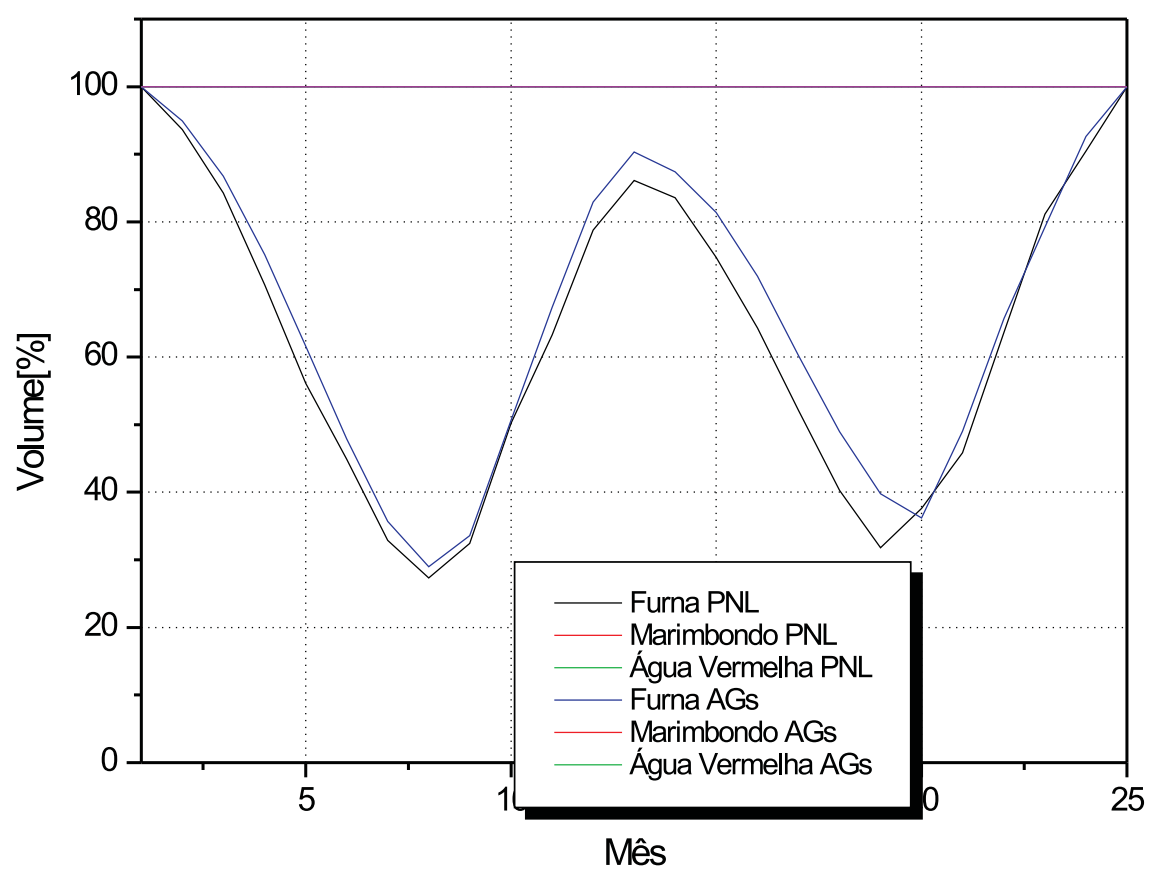

Figura 6.33: Estudo V - Trajetória ótima de volume da cascata do rio Grande

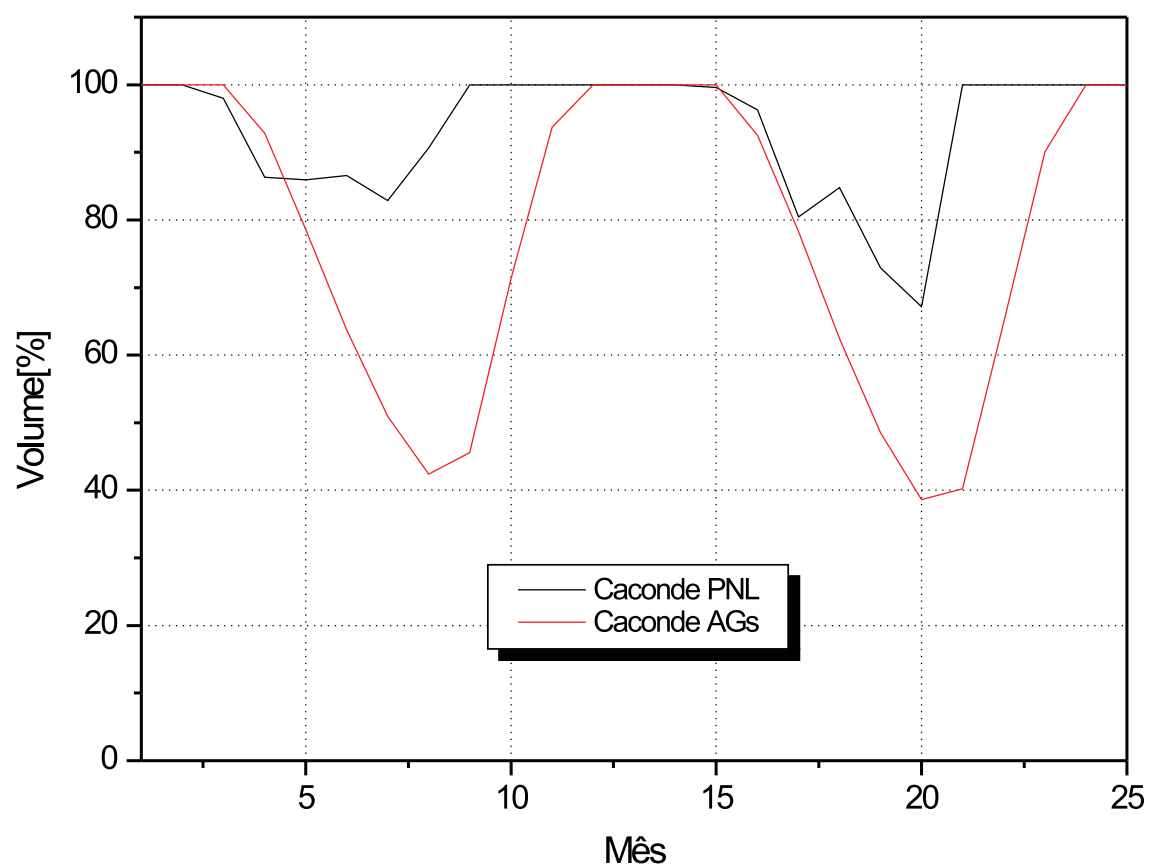

Figura 6.34: Estudo V - Trajetória ótima de volume da cascata do rio Pardo 


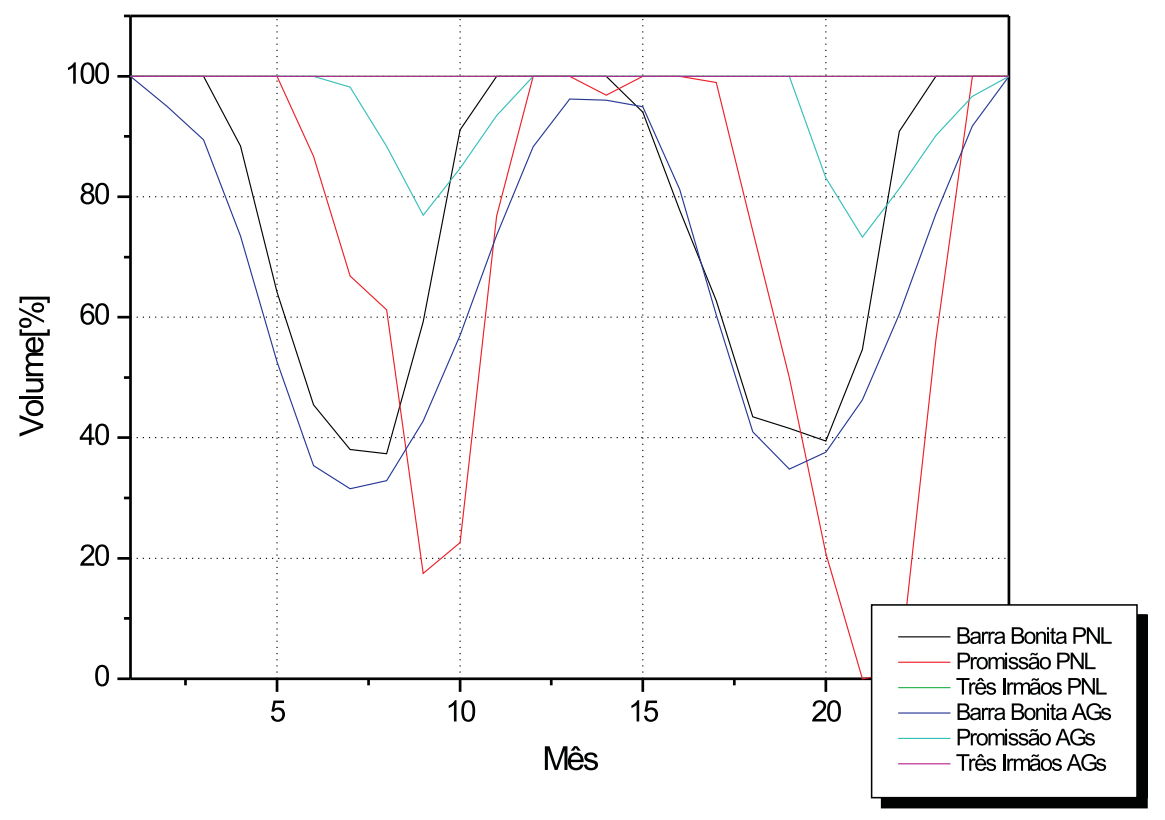

Figura 6.35: Estudo V - Trajetória ótima de volume da cascata do rio Tietê

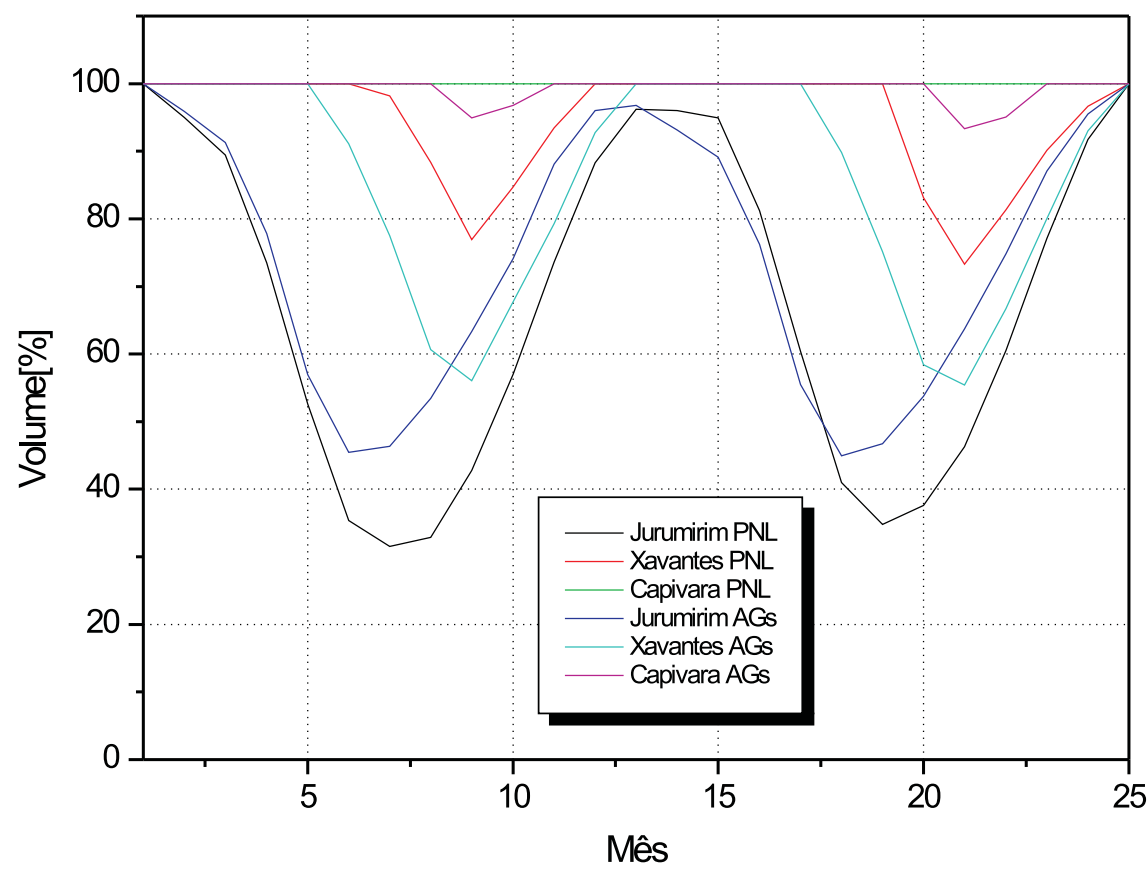

Figura 6.36: Estudo V - Trajetória ótima de volume da cascata do rio Paranapanema 


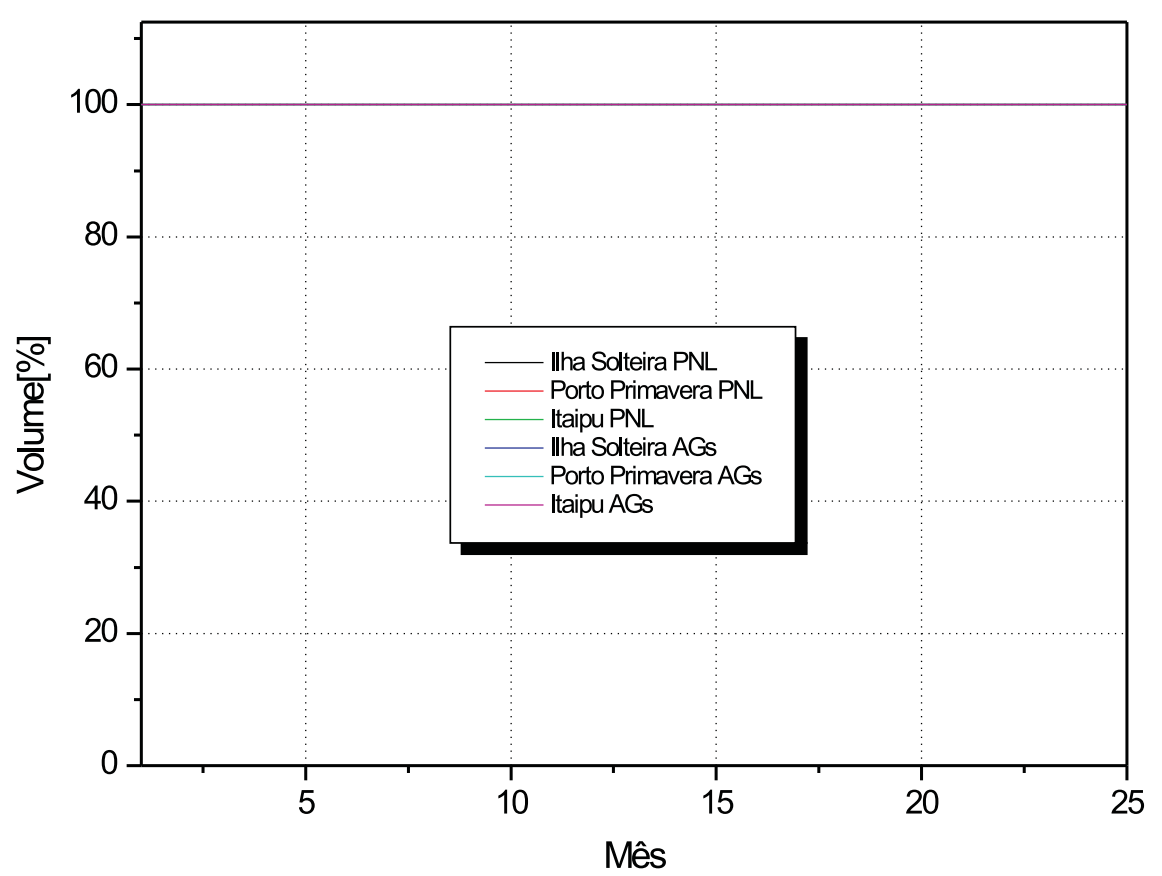

Figura 6.37: Estudo V - Trajetória ótima de volume da cascata do rio Paraná

O bom desempenho do algoritmo pode também ser observado na Figura 6.38 , onde se apresenta a geração hidráulica e a complementação térmica.

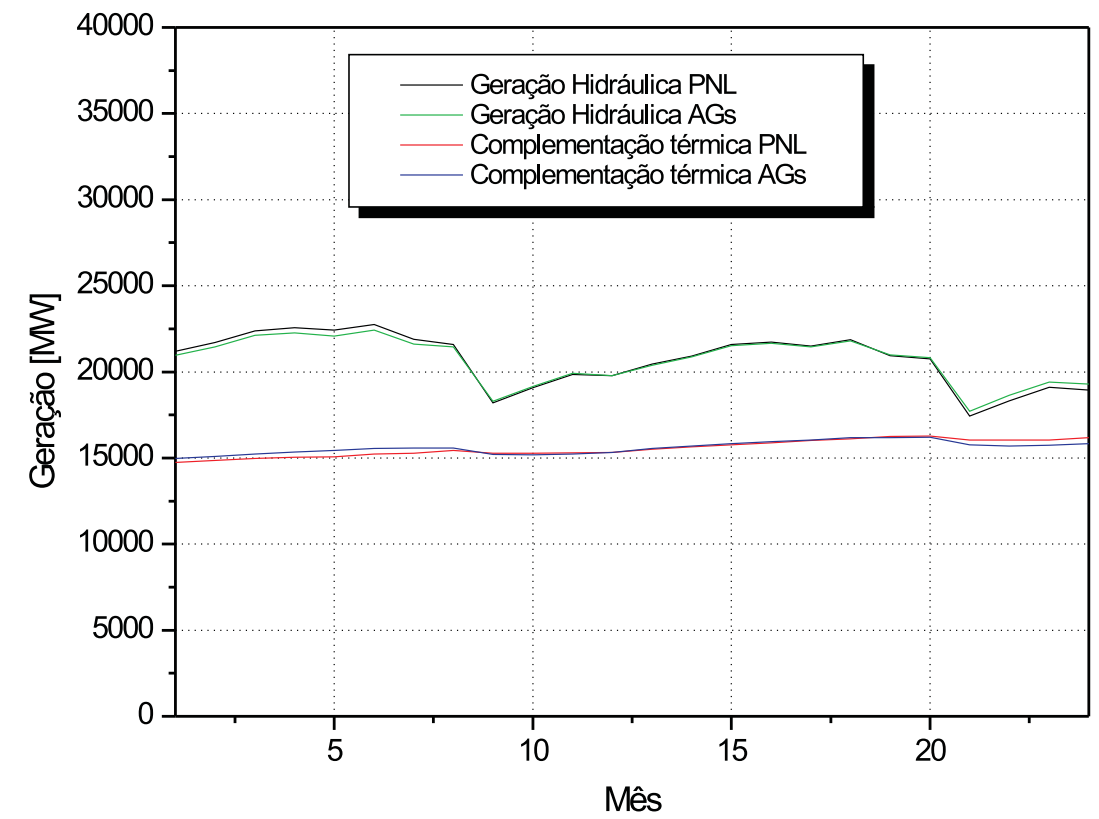

Figura 6.38: Estudo V - Geração Hidráulica e Complementação Térmica das usinas do Sistema Sudeste 


\subsubsection{Teste 3 - Afluência do período histórico de 1947 a 1949}

Finalmente, o último Teste deste Estudo adotou o período histórico de 1947 a 1949. Nas Figuras 6.39 a 6.45 apresentam-se as trajetórias de volumes determinadas pelas duas técnica (PNL e AGs) e fica bem evidenciado o bom desempenho dos AGs em determinar um cronograma de operação, onde não se tem esvaziamentos bruscos como ocorrido quando se adota a técnica de PNL, ou seja, o AGs conseguem suavizar a operação dos reservatórios, o que acredita-se que possa trazer uma forma de operação mais próxima da realidade e segura.

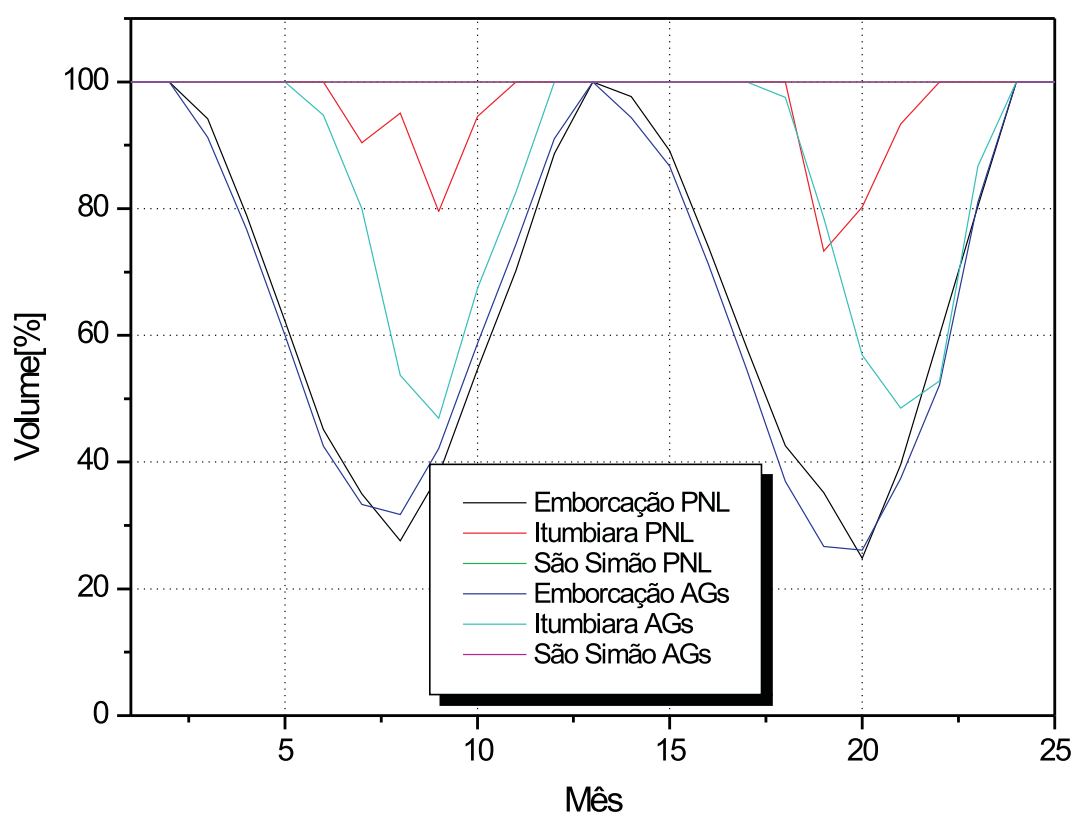

Figura 6.39: Estudo V - Trajetória ótima de volume da cascata do rio Paranaiba 


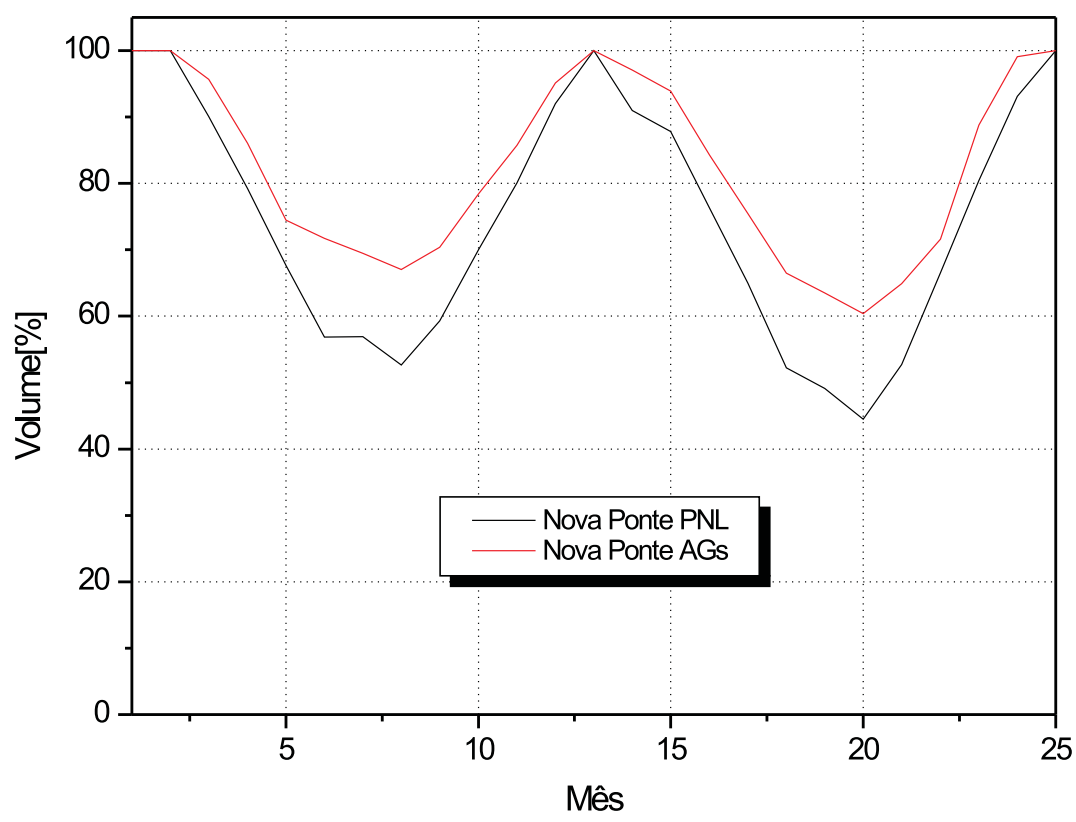

Figura 6.40: Estudo V - Trajetória ótima de volume da cascata do rio Araguari

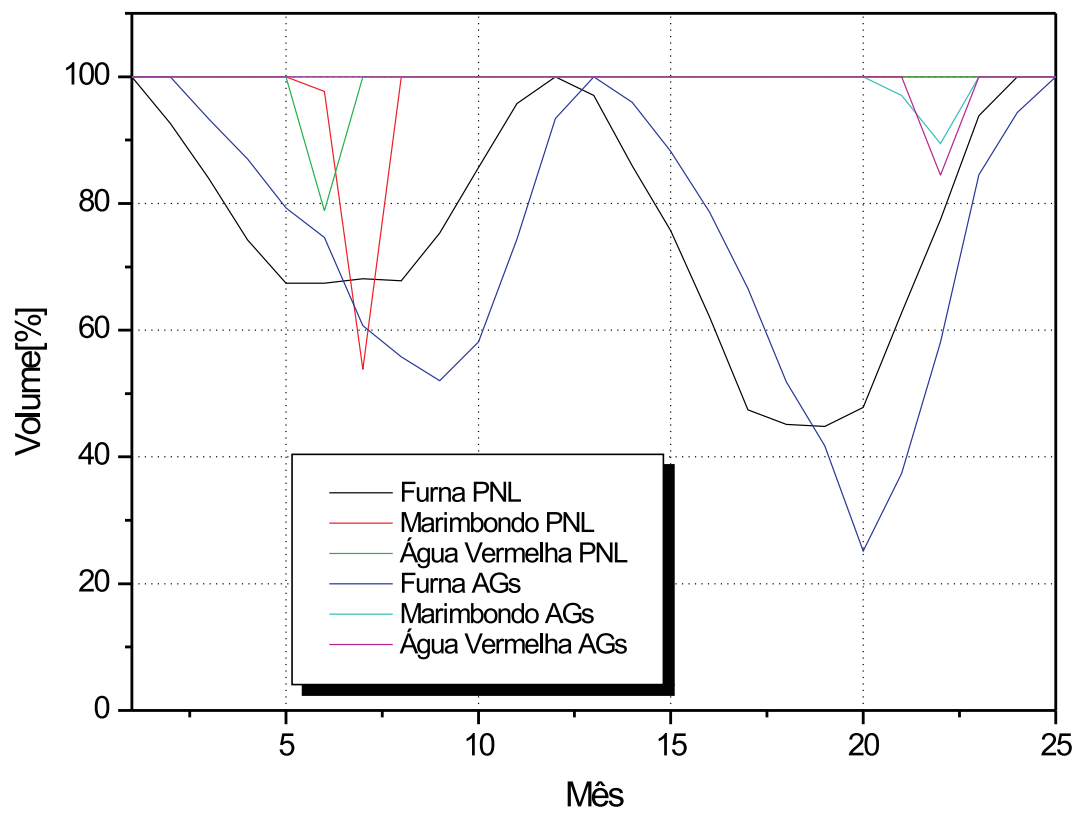

Figura 6.41: Estudo V - Trajetória ótima de volume da cascata do rio Grande 


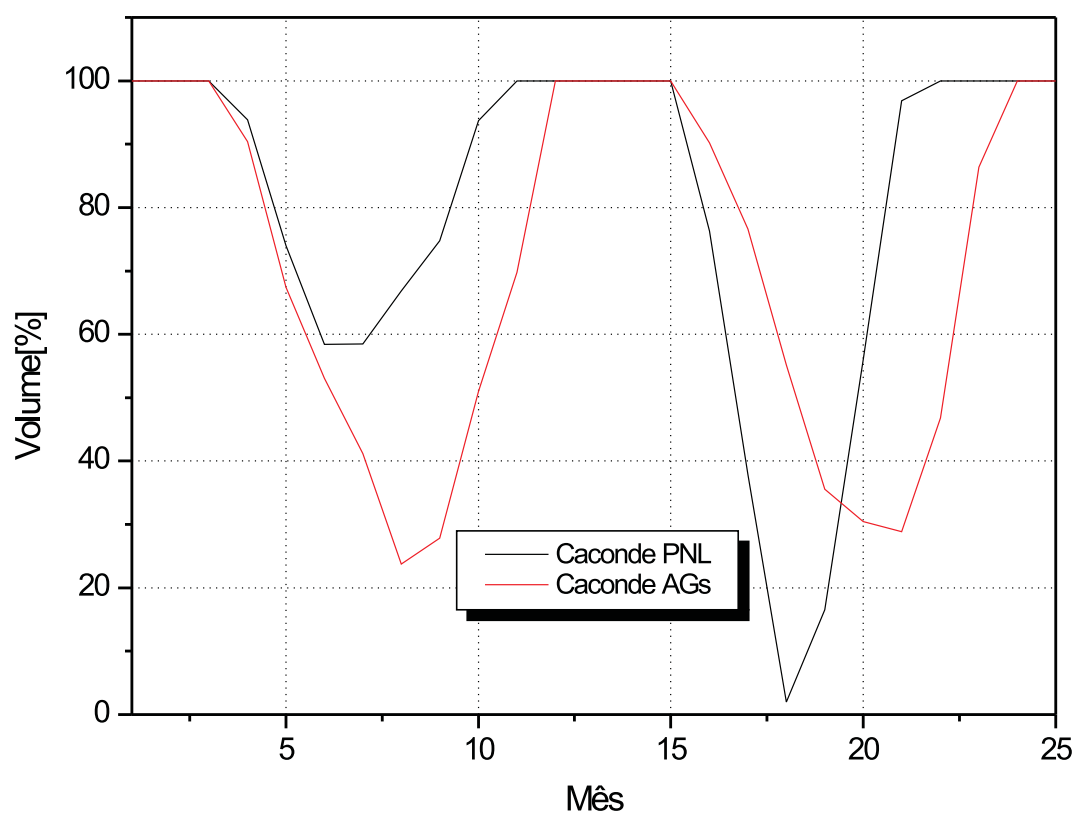

Figura 6.42: Estudo V - Trajetória ótima de volume da cascata do rio Pardo

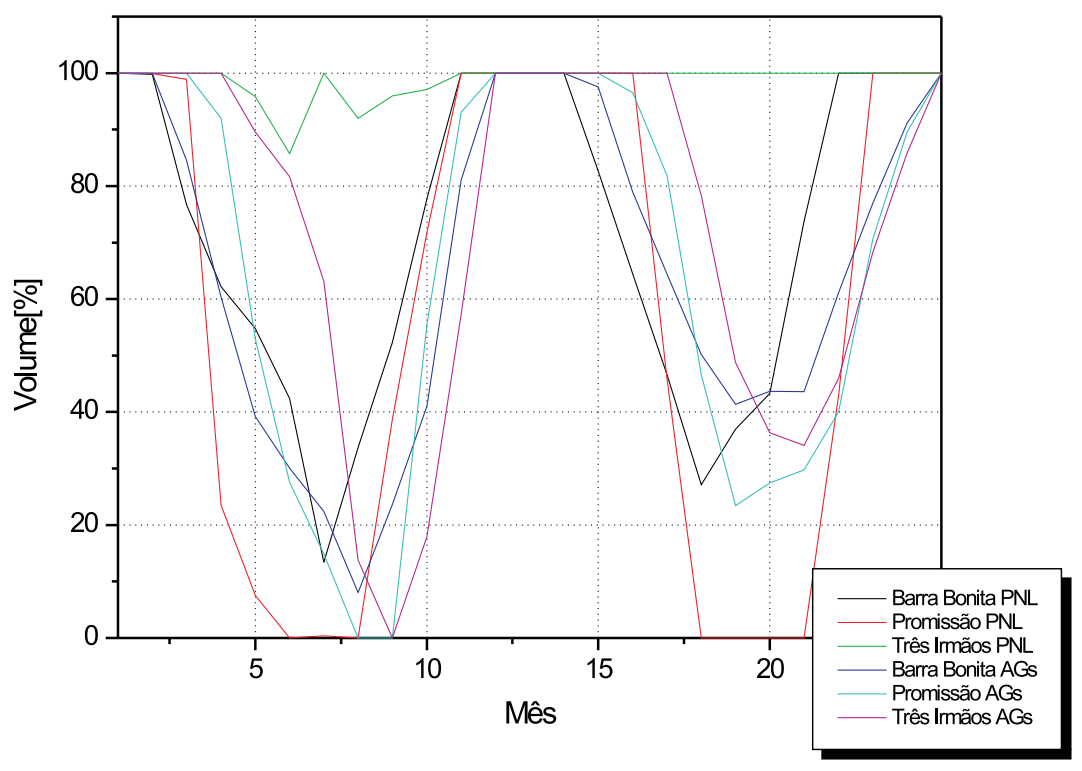

Figura 6.43: Estudo V - Trajetória ótima de volume da cascata do rio Tietê 


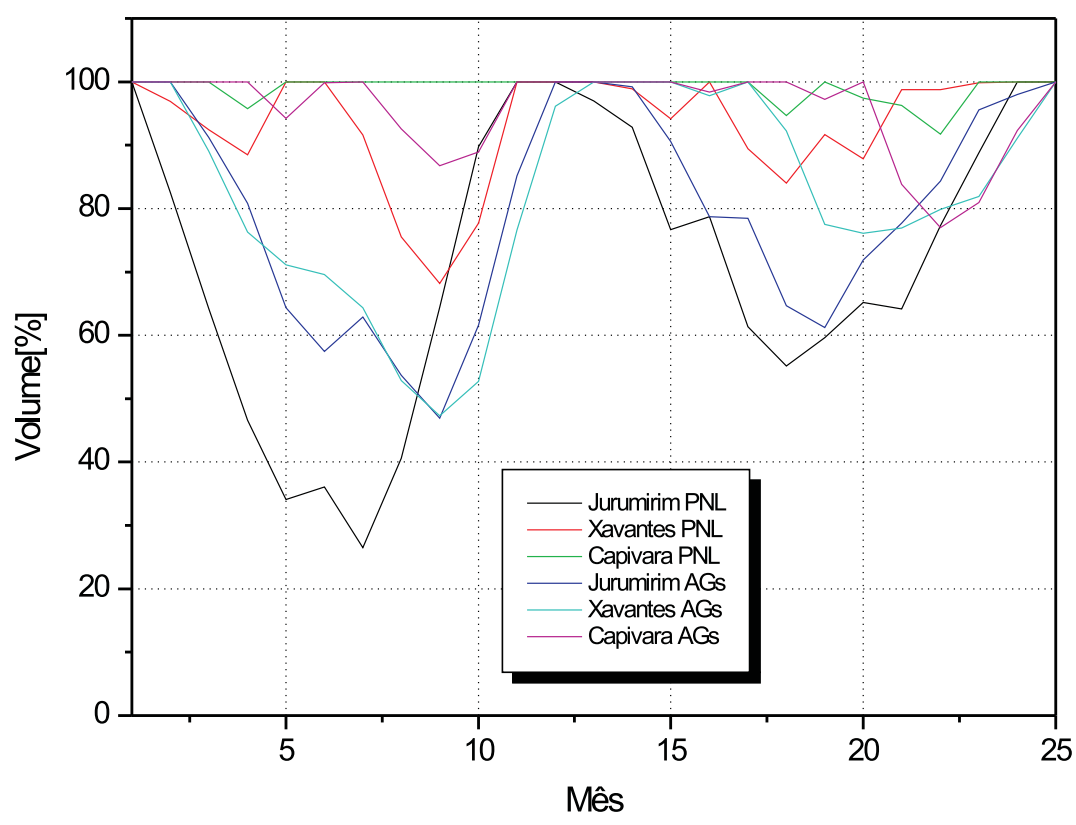

Figura 6.44: Estudo V - Trajetória ótima de volume da cascata do rio Paranapanema

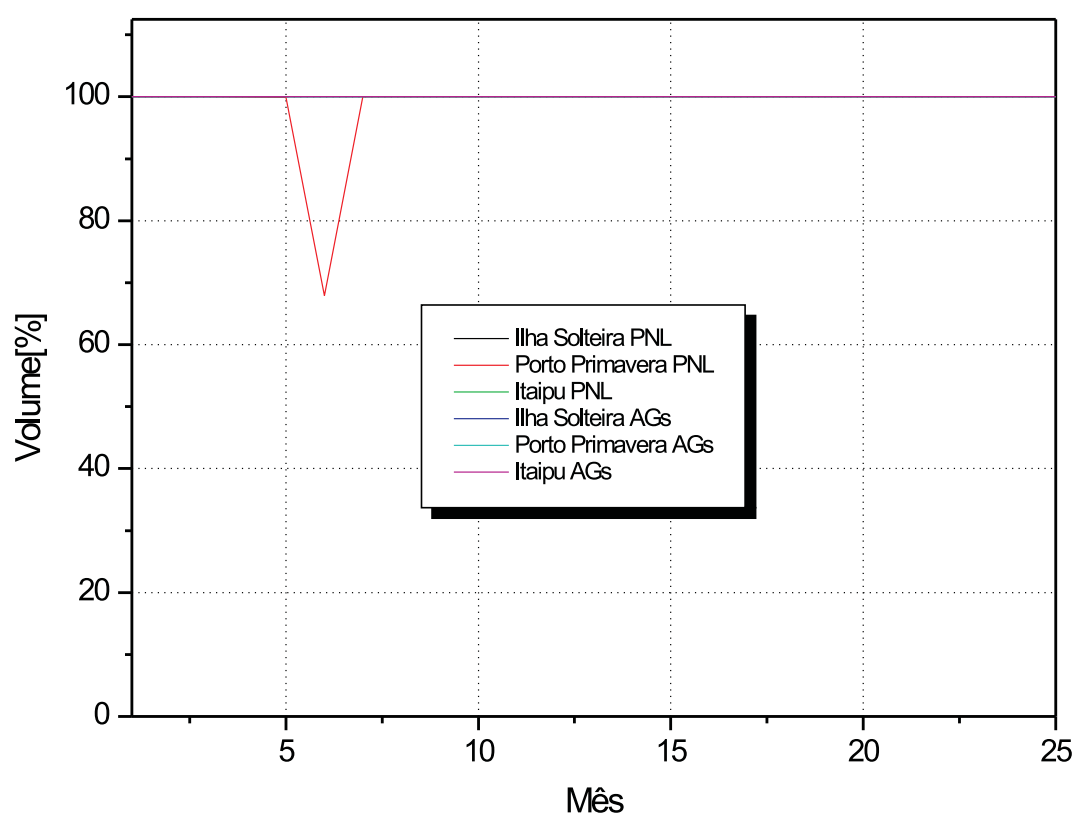

Figura 6.45: Estudo V - Trajetória ótima de volume da cascata do rio Paraná

As curvas de geração hidráulica e complementação térmica do Teste 3 são apresentadas na Figura 6.46 . 


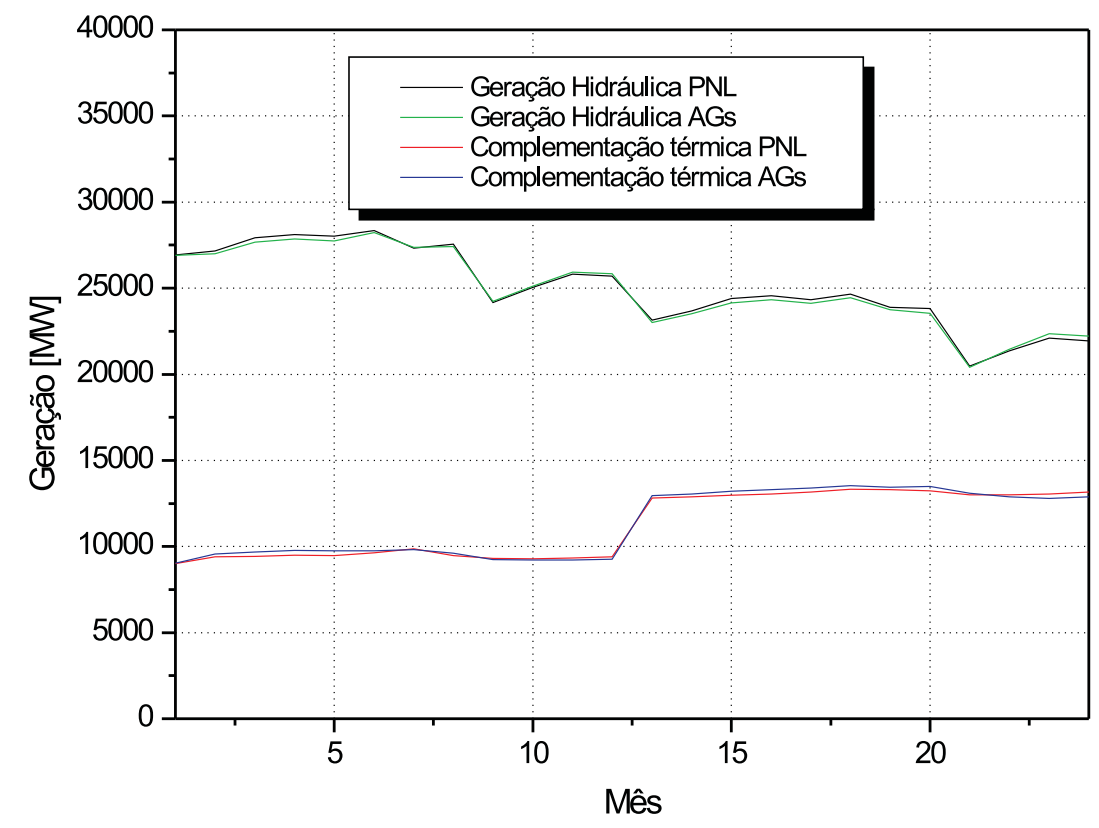

Figura 6.46: Estudo V - Geração Hidráulica e Complementação Térmica das usinas do Sistema Sudeste

Todos os Estudos realizados neste capítulo comprovaram, que as técnicas de Inteligência Artificial, baseadas em Algoritmos Genéticos, são eficientes na resolução de problemas de Planejamento da Operação de Sistemas Hidrotérmicos de Potência. De acordo com as trajetórias de volumes e gerações apresentadas pode-se concluir que em todas as situações de operação e complexidade da cascata os AGs conseguiram apresentar uma boa solução.

Portanto, acredita-se fortemente que este algoritmo proposto poderá auxiliar nos estudos e ações do planejamento da operação resolvendo ou mesmo auxiliando as análises dos gerenciadores do Setor Elétrico Brasileiro. 


\section{Capítulo 7}

\section{Conclusões}

Conforme apresentado neste documento, o referido trabalho mostra a aplicabilidade e potencialidade dos Algoritmos Genéticos no Planejamento da Operação de Sistemas Hidrotérmicos de Potência.

Com relação à técnica adotada, detalhada no capítulo 4, vários testes no que diz respeito a definição do tamanho de uma população eficiente, busca de uma solução inicial mais adequada ao problema e a ponderação dos operadores genéticos utilizados foram considerados nesta fase da pesquisa. Tais análises buscam uma maior segurança na avaliação quanto aos tipos de operadores que melhor se adaptam ao problema e ao emprego de técnicas especiais, como os algoritmos hibrídos, que contribuíram para um melhor desempenho da ferramenta, conforme evidenciado.

Cabe relembrar que o objetivo principal da pesquisa, investigar a aplicação da técnica citada no Planejamento Eletro-Energético, voltado principalmente para o Planejamento Energético de curto prazo, foi exaustivamente avaliado através de testes com usinas pertencentes ao Sistema Sudeste Brasileiro. Estes testes abrangeram desde usina isolada, sistemas com usinas em cascata simples, sistema com várias usinas com cascatas em paralelo, até um complexo sistema de grande porte (35 usinas interligadas hidraulicamente), adotando-se distintas vazões afluentes, o que vem a mostrar a pertinência e a consistência da abordagem, conforme apresentado no capítulo 6 .

Os bons resultados obtidos na aplicação dos AGs mostraram o grande potencial desta ferramenta, que conseguiu captar as diferentes características de operação das usinas, sem a necessidade de simplificar a formulação original do problema. Observou- 
se que em todas as situações os AGs apresentaram um desempenho satisfatório na determinação de uma estratégia de operação que venha a atender as restrições do Planejamento da Operação de Sistemas Hidrotérmicos de Potência.

Ressalta-se também o desempenho dos AGs frente à situação caracterizada por 35 usinas, adotando-se vazões afluentes do período do histórico, como apresentado no capítulo 6, Estudo V.

Vale lembrar que esta pesquisa vem apresentando promissores resultados em eventos científicos como: publicações em periódicos internacionais e nacionais, participações em congressos internacionais e nacionais, destacando-se ainda a sua contribuição como parte de um capítulo de livro, conforme descrito no capítulo 1.

\subsection{Trabalhos Futuros}

Procurando dar continuidade ao trabalho exposto, a seguir, serão apresentadas algumas sugestões para futuros trabalhos.

1. O algoritmo híbrido poderá ser mais explorado com a introdução de outras técnicas de otimização, como por exemplo a busca tabu, simulated annealing, etc.

2. Neste trabalho foi feito um teste de ponderação dos operadores genéticos e isso tornou o algoritmo mais eficiente, mas esta ponderação não foi explorada por completo. Existem várias possibilidades e combinações a serem ainda investigadas, principalmente com a introdução dos operadores baseados no método do gradiente, que só foi totalmente implementado no último ano da pesquisa.

3. O desenvolvimento de uma interface visual para o algoritmo proposto, que facilite a interação do usuário com a ferramenta.

4. Criar uma interface computacional que propicie uma melhor interação entre as técnicas de PNL e AGs.

5. Investigar o comportamento dos AGs, combinado-os com modelos de previsão de vazão. 


\section{Apêndice A}

\section{Algoritmo de Otimização - PNL}

Para resolução do problema do Planejamento Hidrotérmico adota-se um Algoritmo de Otimização não-linear, o qual aproveita a estrutura particular da rede hidráulica, através de procedimentos que norteiam o processo de partição de variáveis em conjunto das variáveis básicas e não básicas. Estes procedimentos compõem a partição dirigida de variáveis e baseiam-se na análise da função objetivo, na análise da função de produção hidráulica, na importância de cada usina no processo otimizador e na experiência do operador. A sua principal característica é a identificação da base por um único índice [ROSENTHAL (1980), SOARES (1987), CARVALHO et al. (1987) e CARVALHO (1986)]

O modelo de fluxo em rede para o problema hidrotérmico, como as suas características e o método de solução, encontra-se em KADOWAKI (1995).

Este algoritmo, considera a estrutura específica de rede do sistema, as estratégias de partição de variáveis, conservando a identidade de cada usina em cada período, começando da usina a montante e progredindo pela cascata até a última usina, para cada intervalo de tempo e consta dos seguintes passos:

1. Inicialize com qualquer solução, como por exemplo a solução a fio d'água;

2. defina o conjunto de prioridade $(\mathrm{P})$ e declare as defluências das outras usinas não pertencentes ao conjunto de prioridade como variáveis básicas;

3. percorra os períodos $(t=1, \ldots ., T)$;

4. percorra as usinas do conjunto de prioridade $i \in P$. 
5. atualize a matriz de defluência básica, considerando a estratégia dinâmica de partição de variáveis;

6. identifique o ciclo e calcule o custo reduzido para a variável não básica associada ao nó $(i, t)$;

7. determine o passo ótimo por busca unidimensional;

8. atualize os volumes, defluência e gradiente das variáveis que pertencem ao ciclo;

9. se existir alguma usina do conjunto de prioridade ainda não considerada, retorne ao Passo 4;

se existir algum período não considerado, retorne ao Passo 3;

caso contrário, vá ao Passo 10;

10. se a convergência ainda não foi obtida, modifique, se necessário o conjunto de prioridade $(\mathrm{P})$ e retorne ao Passo 3;

caso contrário Pare. 


\section{Apêndice B}

\section{Dados das Usinas Hidroelétricas}

Tabela B.1: Dados das usinas hidroelétricas utilizados nos estudos I, II, III, IV e V

\begin{tabular}{|c|c|c|c|c|c|c|c|}
\hline Usinas & $\begin{array}{l}\text { Volume } \\
\text { Máximo } \\
{\left[h m^{3}\right]}\end{array}$ & $\begin{array}{l}\text { Volume } \\
\text { Minimo } \\
{\left[\mathrm{hm}^{3}\right]}\end{array}$ & $\begin{array}{l}\text { Volume } \\
\text { Útil }\left[\mathrm{hm}^{3}\right]\end{array}$ & $\begin{array}{l}\text { Turbinagem } \\
\text { Máxima } \\
{\left[\mathrm{hm}^{3}\right]}\end{array}$ & $\begin{array}{l}\text { Turbinagem } \\
\text { Minima } \\
{\left[\mathrm{hm}^{3}\right]}\end{array}$ & $\begin{array}{l}\text { Engolimento } \\
\text { Efetivo } \\
{\left[\mathrm{hm}^{3}\right]}\end{array}$ & $\begin{array}{l}\text { Potência } \\
\text { instalada } \\
{[M W]}\end{array}$ \\
\hline Emborcação & 17190 & 4669 & 12521 & 2754.144 & 202.356 & 2754.144 & 1192 \\
\hline $\begin{array}{l}\text { Nova } \\
\text { Ponte }\end{array}$ & 12810 & 2435 & 12810 & 1561.032 & 123.516 & 1561.032 & 510 \\
\hline Miranda & 1120 & 1120 & & 1750.248 & 583.416 & 1750.248 & 390 \\
\hline Itumbiara & 17027 & 4573 & 12454 & 8467.416 & 667.512 & 8467.416 & 2080 \\
\hline $\begin{array}{l}\text { Cachoeira } \\
\text { Dourada }\end{array}$ & 460 & 460 & & 6606.792 & 6606.792 & 6606.792 & 439 \\
\hline São Simão & 12540 & 7000 & 5540 & 11826 & 1069.596 & 11826 & 1680 \\
\hline Camargo & 792 & 120 & 672 & 599.184 & 84.096 & 599.184 & 45 \\
\hline Itutinga & 11 & 11 & & 643.86 & 643.86 & 643.86 & 49 \\
\hline Furnas & 22950 & 5733 & 17217 & 4446.576 & 515.088 & 4446.576 & 1312 \\
\hline Peixoto & 4234 & 1540 & 2500 & 3489.984 & 649.116 & 3489.984 & 476 \\
\hline Estreito & 1423 & 1423 & & 5329.584 & 5329.584 & 5329.584 & 1104 \\
\hline Jaguará & 450 & 450 & & 4110.192 & 4110.192 & 4110.192 & 426 \\
\hline $\begin{array}{l}\text { Volta } \\
\text { Grande }\end{array}$ & 2338 & 2338 & & 4162.752 & 4162.752 & 4162.752 & 380 \\
\hline $\begin{array}{l}\text { Porto } \\
\text { Colômbia }\end{array}$ & 1524 & 1524 & & 5224.464 & 5224.464 & 5224.464 & 320 \\
\hline
\end{tabular}




\begin{tabular}{|c|c|c|c|c|c|c|c|}
\hline Marimbondo & 6150 & 890 & 5260 & 7736.832 & 1158.948 & 7736.832 & 1488 \\
\hline $\begin{array}{l}\text { Água Ver- } \\
\text { melha }\end{array}$ & 11025 & 5856 & 5169 & 7679.016 & 1316.628 & 7679.016 & 1380 \\
\hline Caconde & 555 & 51 & 504 & 247.032 & 123.516 & 247.032 & 80 \\
\hline $\begin{array}{l}\text { Euclides } \\
\text { da Cunha }\end{array}$ & 14 & 14 & & 388.944 & 360.036 & 388.944 & 108 \\
\hline $\begin{array}{l}\text { A.S } \\
\text { Oliveira }\end{array}$ & 25 & 25 & & 412.6 & 49 & 467.784 & 32 \\
\hline $\begin{array}{l}\text { Barra } \\
\text { Bonita }\end{array}$ & 3155 & 569 & 2586 & 1994.652 & 110.376 & 1994.652 & 140 \\
\hline Bariri & 544 & 544 & & 2026.188 & 675.396 & 2026.188 & 144 \\
\hline Ibitinga & 985 & 985 & & 1852.74 & 617.58 & 1852.74 & 132 \\
\hline Promissão & 7408 & 5280 & 2128 & 3398.004 & 346.896 & 3398.004 & 264 \\
\hline $\begin{array}{l}\text { Nova } \\
\text { Avanha- } \\
\text { dava }\end{array}$ & 2700 & 2700 & & 3279.744 & 1093.248 & 3279.744 & 303 \\
\hline $\begin{array}{l}\text { Três } \\
\text { Irmão }\end{array}$ & 13550 & 10110 & 3440 & 4593.744 & 394.2 & 4593.744 & 648 \\
\hline Jurumirim & 7008 & 3843 & 3165 & 935.568 & 134.028 & 935.568 & 98 \\
\hline Xavantes & 8795 & 5754 & 3041 & 1702.944 & 194.472 & 1702.944 & 416 \\
\hline $\begin{array}{l}\text { Salto } \\
\text { Grande }\end{array}$ & 78 & 78 & & 346.896 & 28.908 & 346.896 & 102 \\
\hline Capivara & 10540 & 4816 & 5724 & 4583.232 & 575.532 & 4583.232 & 640 \\
\hline Taquaruçu & 1120 & 1120 & & 6859.08 & 1371.816 & 6859.08 & 505 \\
\hline Rosana & 1930 & 1930 & & 6391.296 & 1597.824 & 6391.296 & 320 \\
\hline $\begin{array}{l}\text { Ilha } \\
\text { Solteira }\end{array}$ & 21060 & 8232 & 12828 & 23231.52 & 3363.84 & 23231.52 & 3240 \\
\hline Jupiá & 3680 & 3680 & & 9978.056 & 425.004 & 9978.056 & 1414 \\
\hline Itaipu & 29000 & 24000 & 5000 & 31078.728 & 7140.276 & 31078.728 & 12600 \\
\hline \multicolumn{8}{|c|}{ Potência instalada total para as 35 usinas $=36271.0$} \\
\hline
\end{tabular}




\section{Apêndice $\mathrm{C}$}

\section{Estudos Complementares}

Nos Estudos complementares, foram introduzidas usinas a fio d'água em pequenos sistemas testes e os estudos foram realizados para observar a influência dessas usinas nesse sistemas, e para analisar o comportamentos dos Algoritmos Genéticos.

Estudo complementar I - Emborcação/Itumbiara/Cachoeira Dourada/São Simão

A primeira cascata utiliza as usinas hidroelétricas de Emborcação, Itumbiara, Cachoeira Dourada (usina a fio d'água) e São Simão, localizadas no Rio Paranaíba, como apresentado na Figura C.1. As afluências adotadas são iguais a $100 \%$ da MLT, período de planejamneto adotado será de 12 meses e o mercado de energia que o sistema gerador deve atender igual a $4800 \mathrm{MW}$.

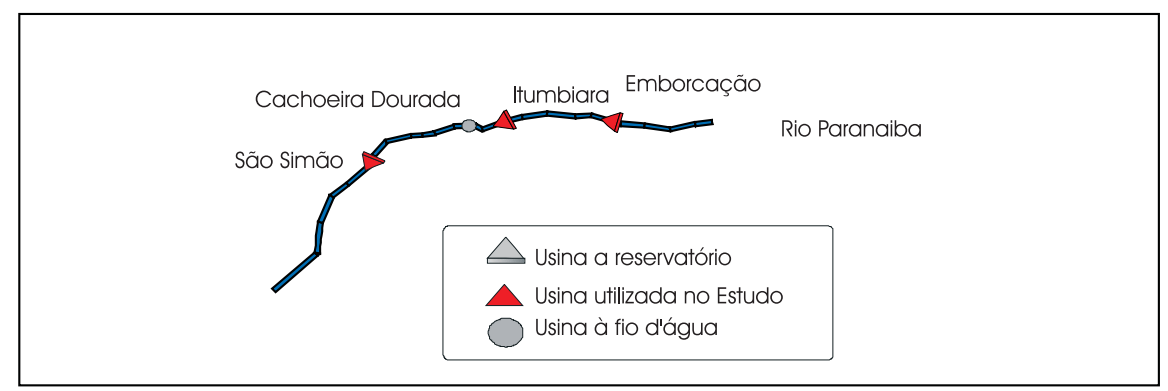

Figura C.1: Cascata utilizada no Estudo Complementar I

Na Figura C.2, apresenta-se a MLT para as quatro usinas consideradas neste Estudo. A Figura C.3 mostra as trajetórias de volume sem a usina fio d'água Cachoeira Dourada 
e com esta adicionada a cascata após a usina de Itumbiara. O comportamento de operação das usinas do segundo o estudo não sofreu grandes alterações em relação ao primeiro.

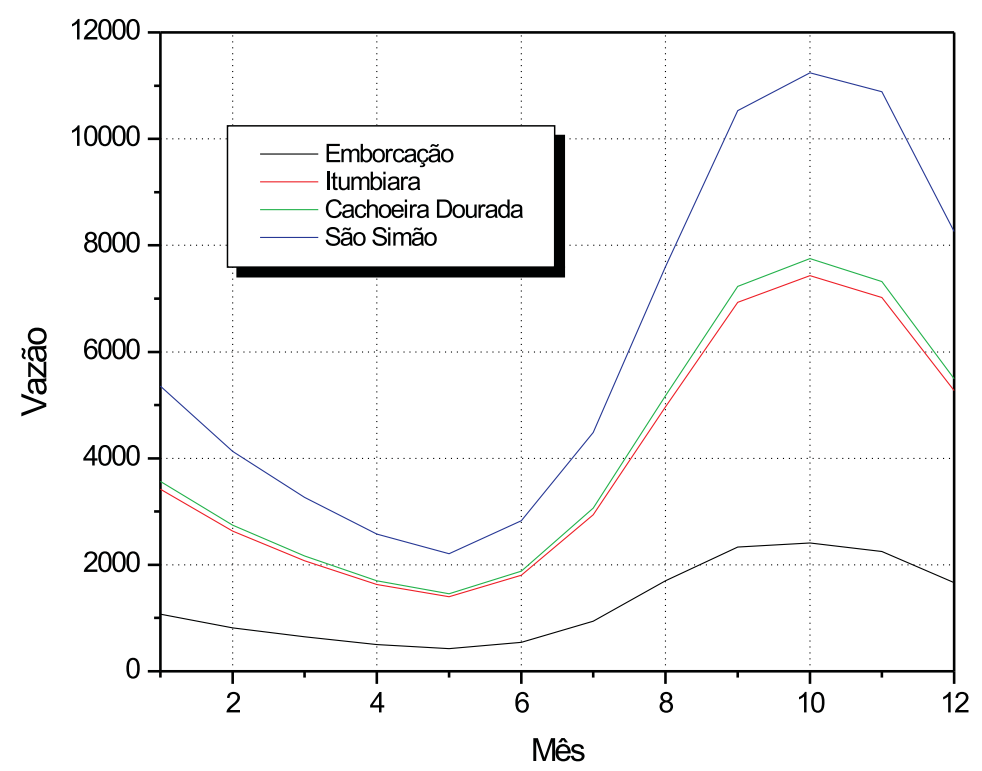

Figura C.2: Afluência natural utilizada no Estudo Complementar I (MLT)

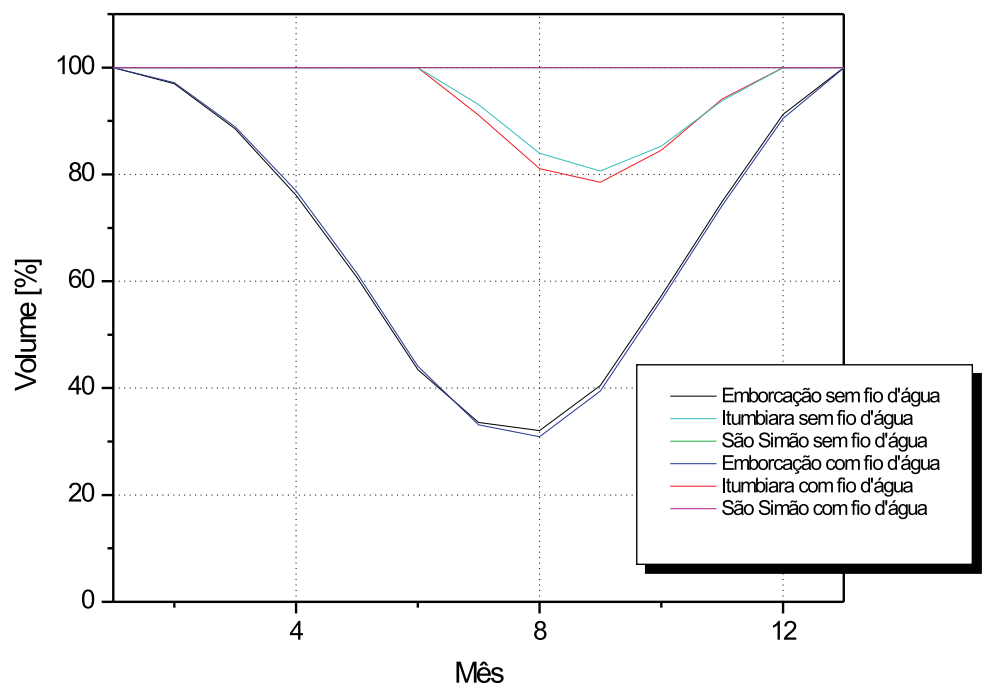

Figura C.3: Estudo Complementar I - Trajetória ótima de volume 
As trajetórias de defluência, apresentada na Figura C.4, assim como as de volume não sofreram grandes modificações em relação ao estudo sem a usina a fio d'água.
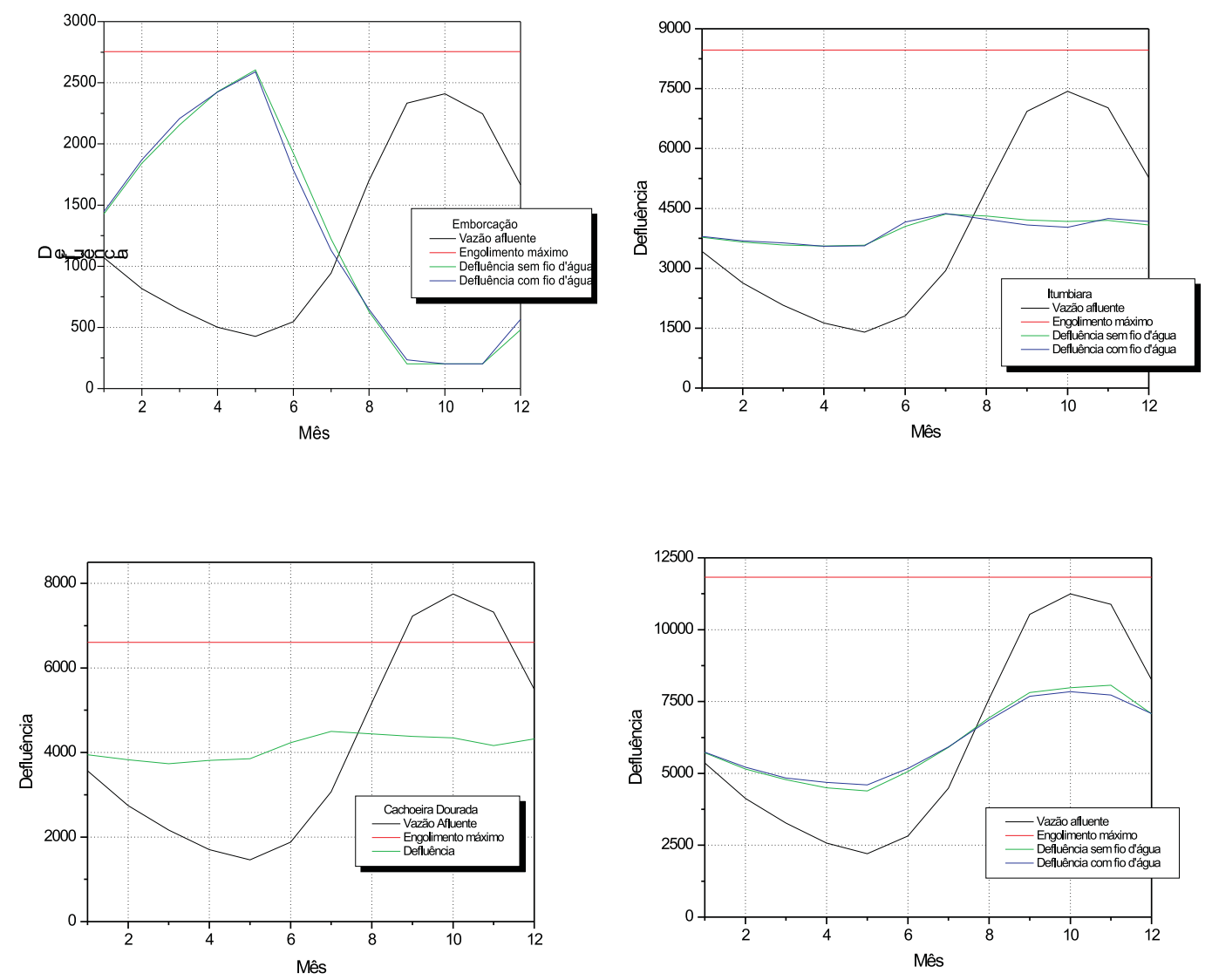

Figura C.4: Trajetórias de Vazão afluentes, vazão turbinada máxima e defluência das usinas hidroelétricas de Emborcação, Itumbiara, Cachoeira Dourada e São Simão.

Através das trajetórias de defluência e volume, pode-se concluir que não houve mudanças significativas nos resultados do estudo com a usina a fio d'água, o que era esperado devido as características de operação da usina a fio d'água.

Na Figura C.5, são apresentadas as curvas de geração hidráulica e na Figura C.6, são mostradas as complementações térmicas ao longo do período de planejamento. Observe que não houve grandes alterações no comportamento da geração de energia ao longo do período de planejamento. 


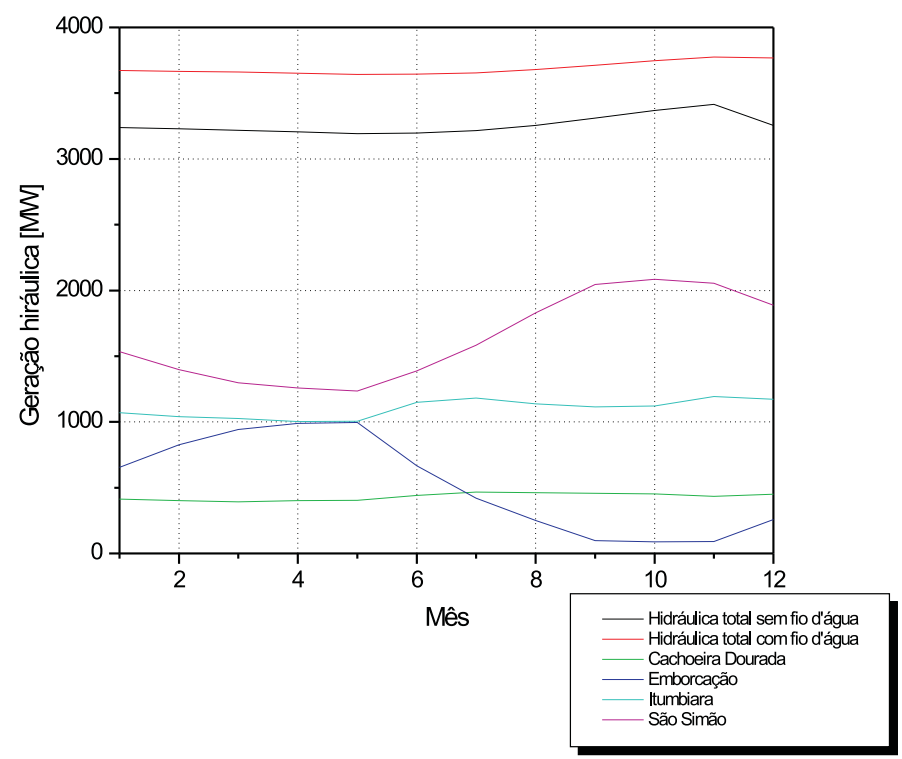

Figura C.5: Estudo Complementar I - Geração hidráulica.

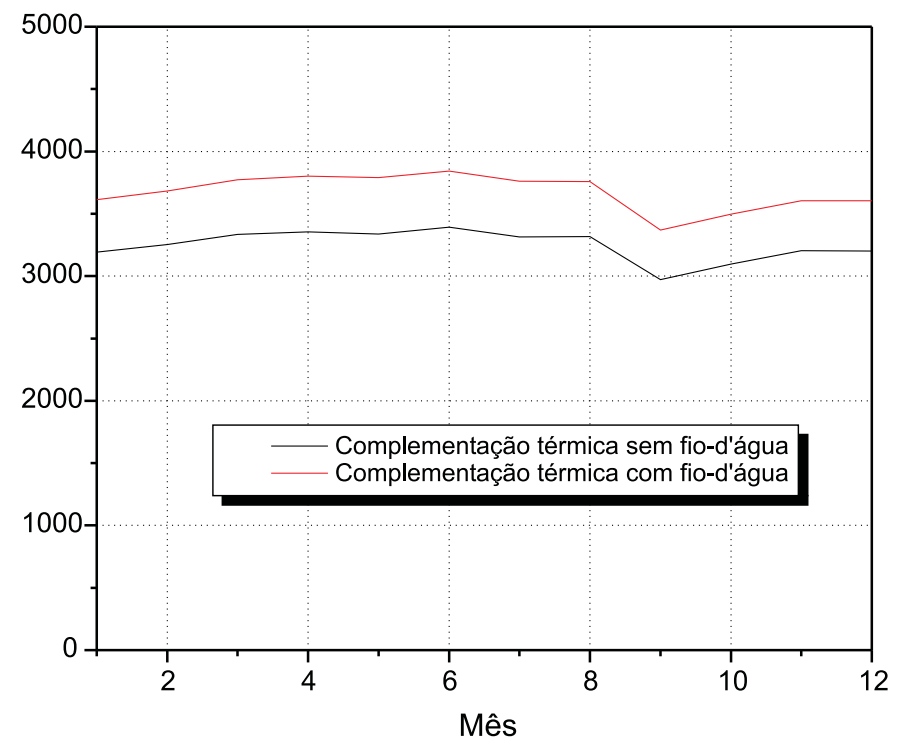

Figura C.6: Estudo Complementar I - Complementação térmica.

Para atestar o comportamento do algoritmo proposto em cascatas composta por usinas a fio d'água e reservatórios, foram feitos mais dois estudos com configurações de sistemas hidrogeradores diferentes. 


\section{Estudo complementar II - Furnas/Estreito/Água Vermelha}

Neste estudo serão adotas as usinas localizadas no Rio Grande, como mostrado na Figura C.12. As afluências para as três usinas são iguais a 100\% da MLT.

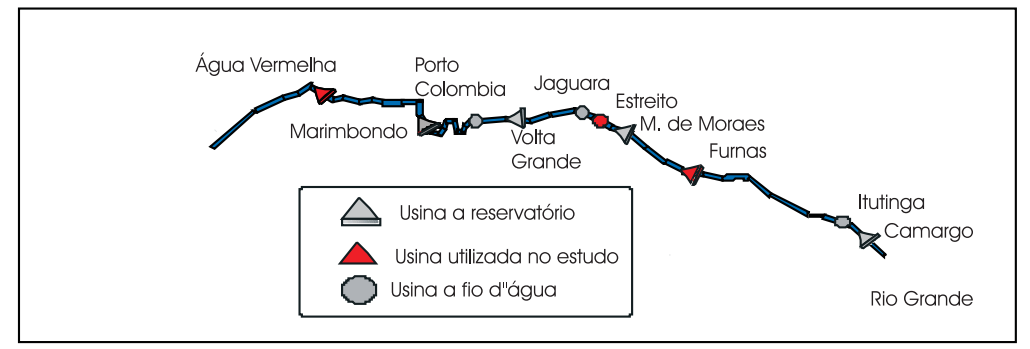

Figura C.7: Estudo Complementar II - Cascata do Rio Grande utilizada no estudo.

Semelhante ao caso anterior as trajetórias de volumes das usinas pertencentes a esse estudo não sofreram grandes modificações ao longo do período de planejamento, como pode ser observado na Figura C.8.

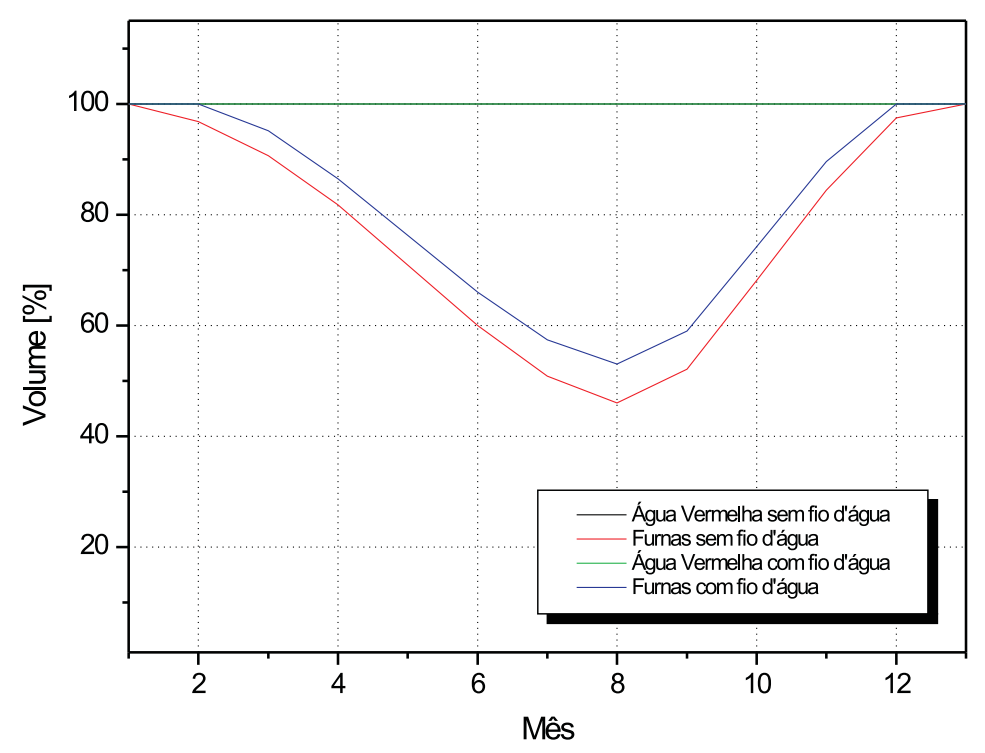

Figura C.8: Estudo Complementar II - Trajetória de volume.

Na Figura C.9, são apresentadas as trajetórias de defluência, engolimento máximo 
e vazão natural para todas as usinas utilizada no estudo II. Observe que a regularização feita por Furnas foi suficiente para eliminar vertimento na usina de Estreito.

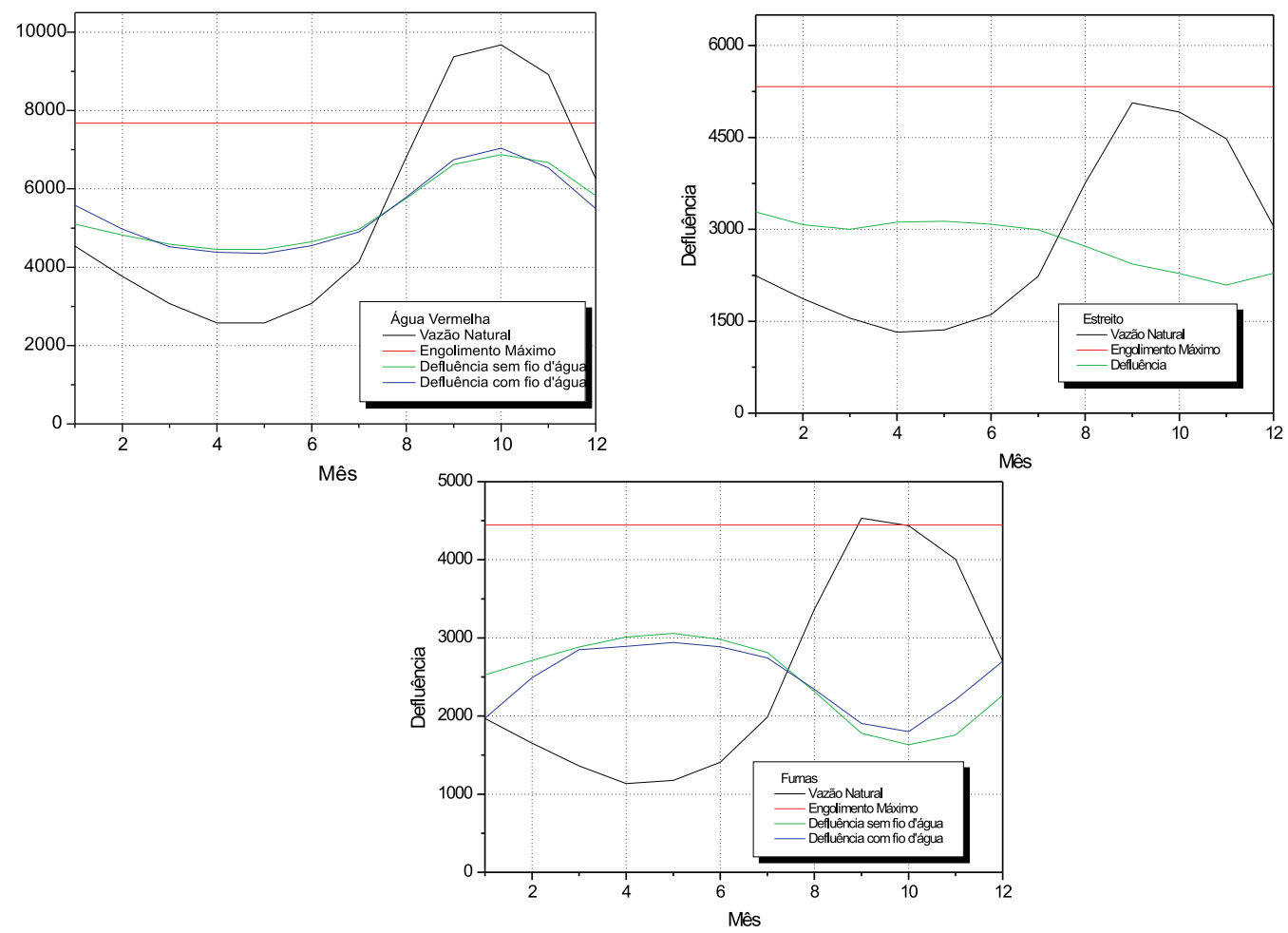

Figura C.9: Estudo Complementar II - Vazão afluente, vazão turbinada máxima e defluência das usinas hidroelétricas de Água Vermelha, Estreito e Furnas.

Através das trajetórias de geração hidráulica, mostrada na Figura C.10 e da complementação térmica apresentada na Figura C.11, mais um vez é comprovado que a usina a fio d'água não exerce grande influência na operação das usinas do sistema teste, pois as trajetórias de defluência e volume não sofreram grandes alterações.

O algoritmo teve o mesmo desempenho em cascatas semelhantes apesar de usinas com características construtivas diferente. O próximo e último estudo será com um número de usinas a reservatório e a fio-d'água mais expressivo. 


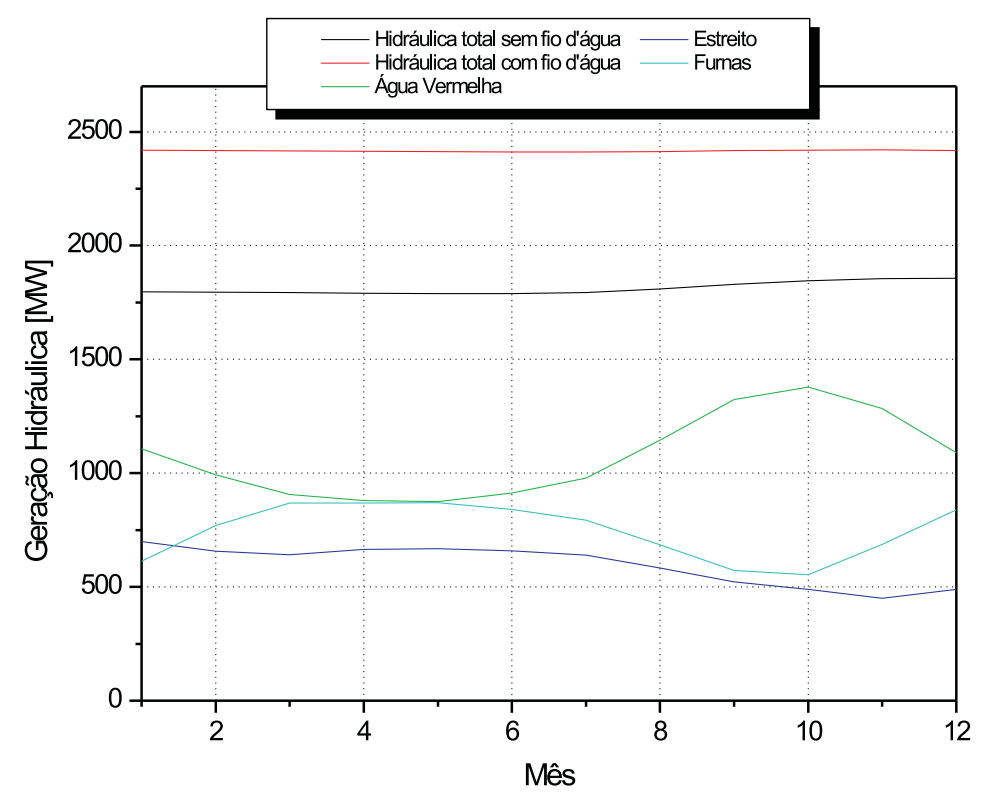

Figura C.10: Estudo Complementar II - Geração hidráulica.

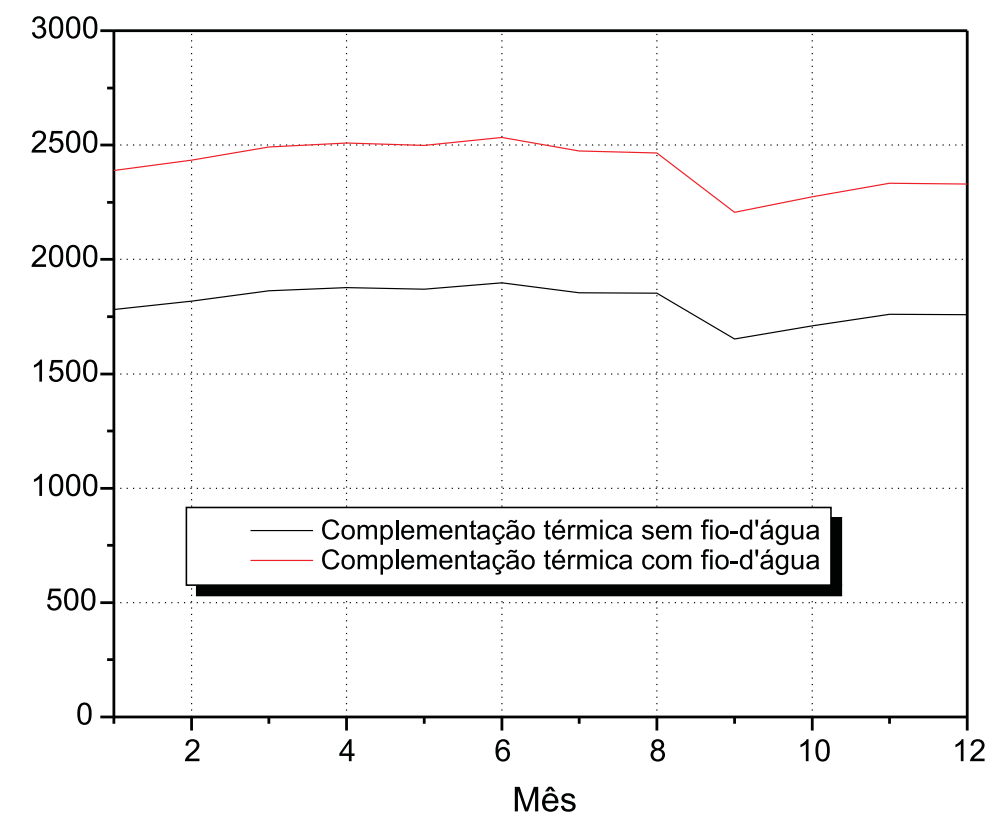

Figura C.11: Estudo Complementar II - Complementação Térmica. 


\section{Estudo complementar III - Camargo/Itutinga/Furnas/Peixoto/Estreito/} Jaguará/Volta Grande/Porto Colômbia/Marimbondo/Água Vermelha

No terceiro e último caso desse estudo, foram acrescentadas ao sistema teste anterior três usinas a reservatório, Camargo, Marimbondo e Peixoto, e mais quatro usinas a fio d'água, Itutinga, Jaguará, Volta Grande e Porto Colômbia, conforme mostrado na C.12.

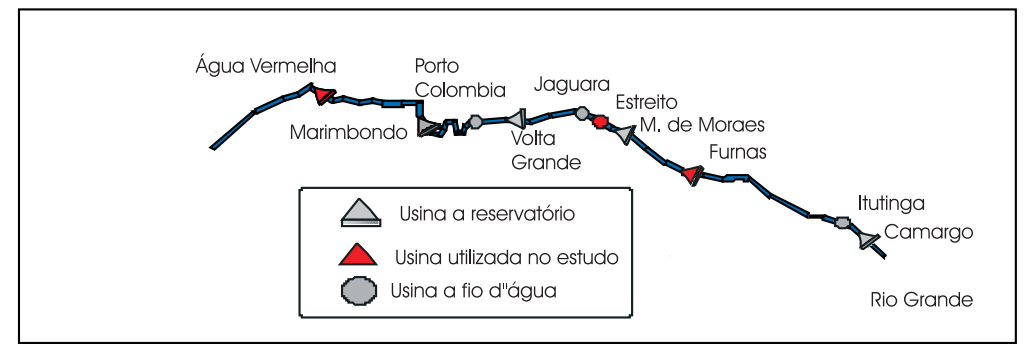

Figura C.12: Estudo Complementar II - Cascata do Rio Grande utilizada no estudo.

Na Figura C.13, são apresentadas as trajetórias ótimas de volumes para o estudo complementar III.

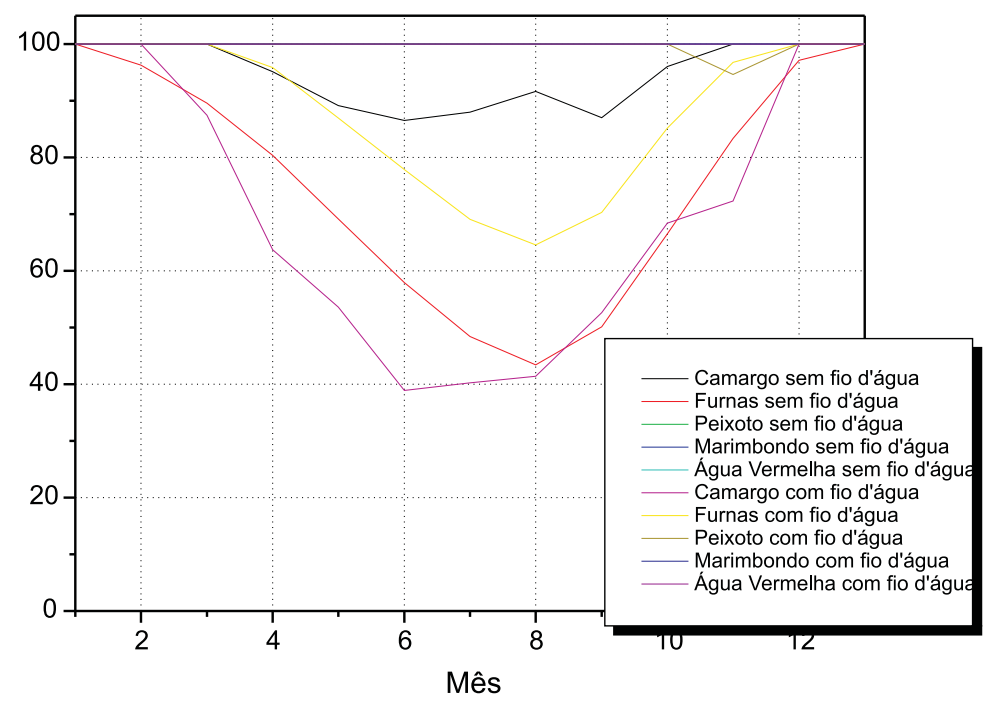

Figura C.13: Estudo Complementar III - Trajetória de volume. 
Observe que apenas duas usinas a de Camargo e Furnas tiveram alterações significativas, nas trajetórias de volume, após a introdução das usinas a fio-d'água. O que pode ter ocorrido para evitar modificações na geração de energia.
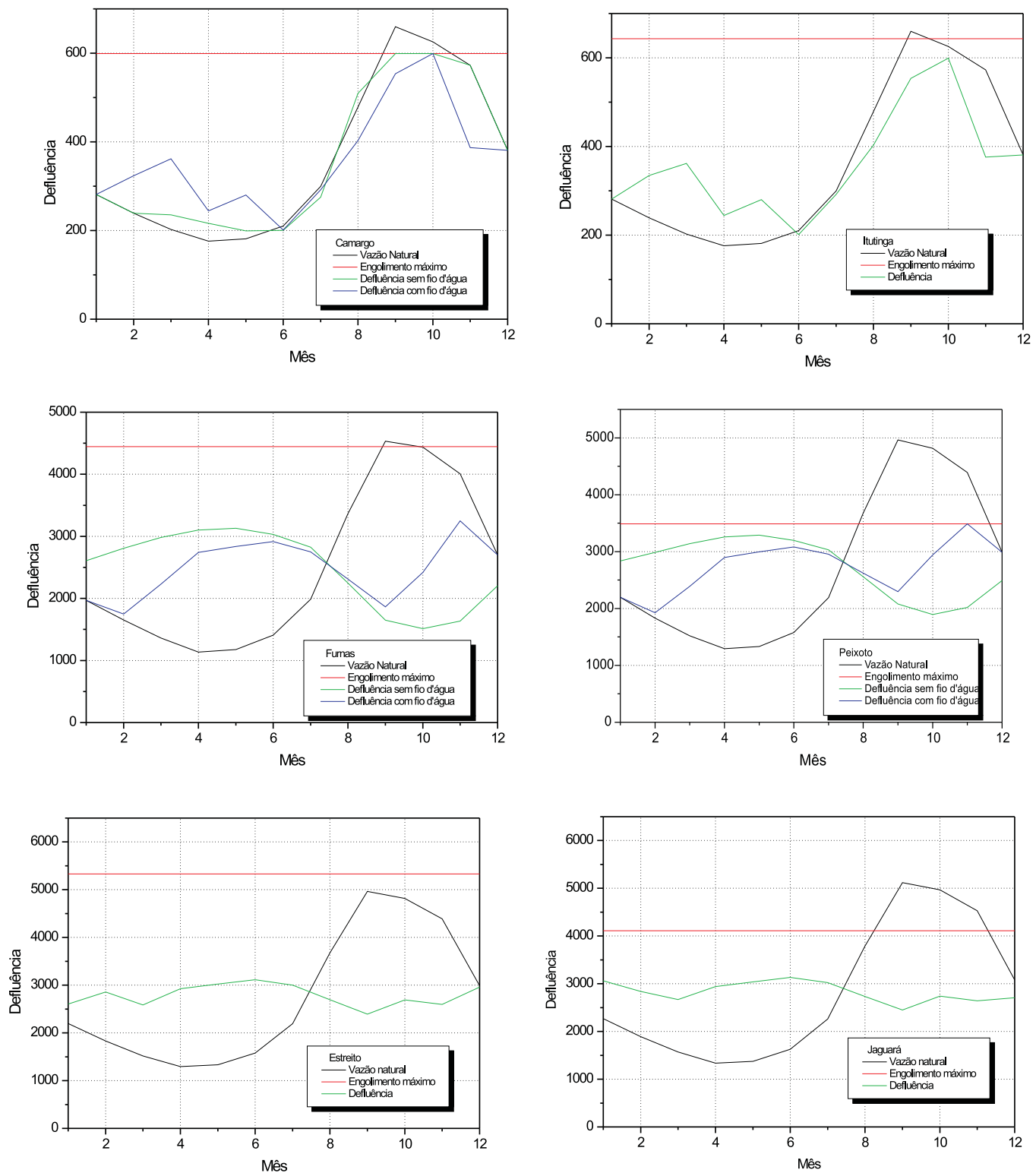

Figura C.14: Estudo Complementar III - Vazão afluente, vazão turbinada máxima e defluência das usinas hidroelétricas de Camargo, itutinga, Furnas, Peixoto, Estreito e Jaguará. 

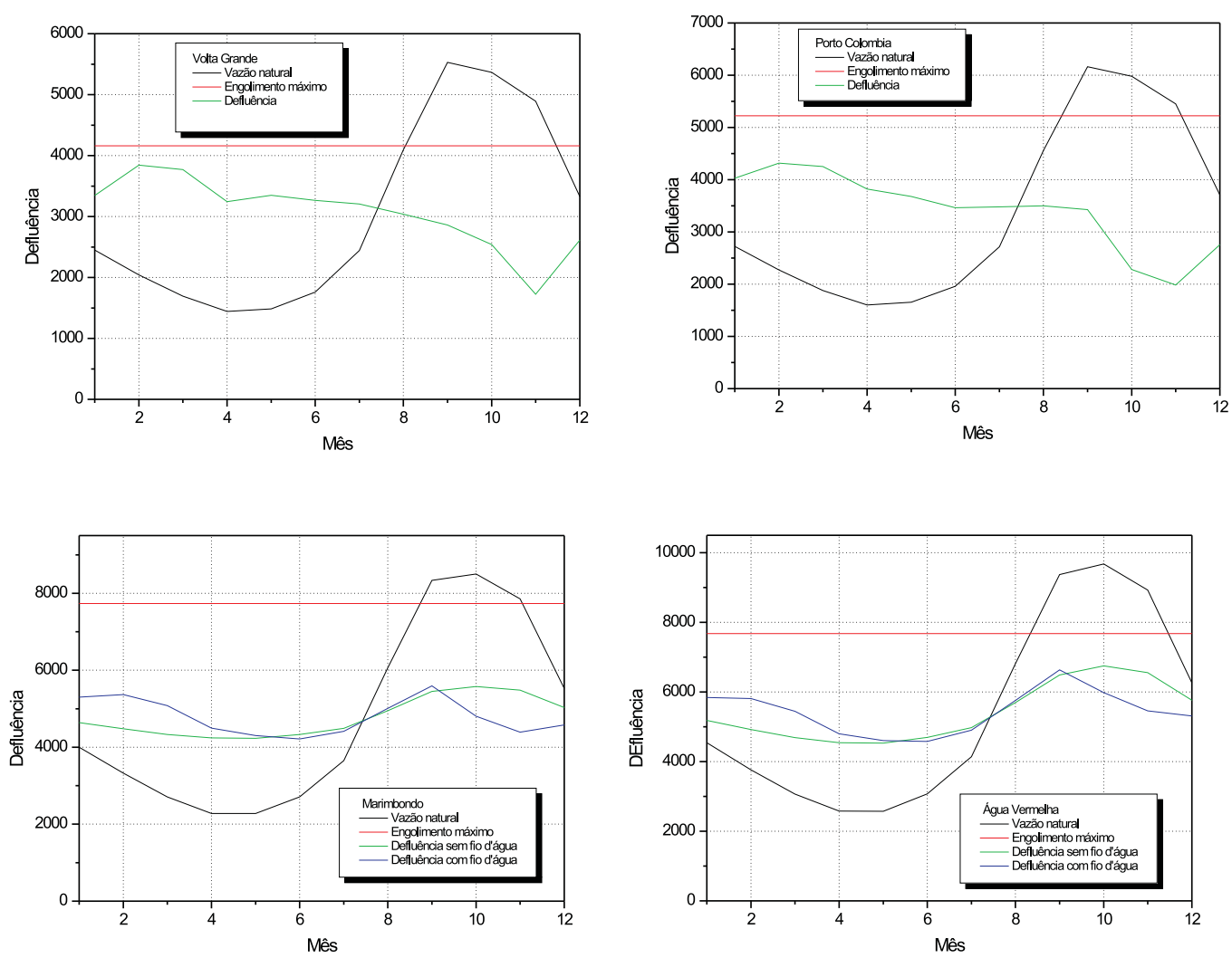

Figura C.15: Estudo Complementar III - Vazão afluente, vazão turbinada máxima e defluência das usinas hidroelétricas de Volta Grande, Porto Colômbia, Marimbondo e Água Vermelha.

Através da Figura C.16, pode-se analisar a geração hidráulica das usinas e a geração total. A característica de geração não alterou com a introdução das usinas a fiod'água. Portanto, as alterações apresentadas nas defluências ocorreram para que a complementação térmica fosse mais uniforme possível em conseqüência de uma geração hidráulica praticamente constante.

O gráfico da complementação térmica mostrado na Figura C.17, confirma o bom desempenho dos AGs, como uma ferramenta auxiliar no Planejamento da Operação de Sistema Hidrotérmicos de Potência, pois consegue captar sem dificuldade as características de operação das diferentes usinas em diversas situações operativa. 


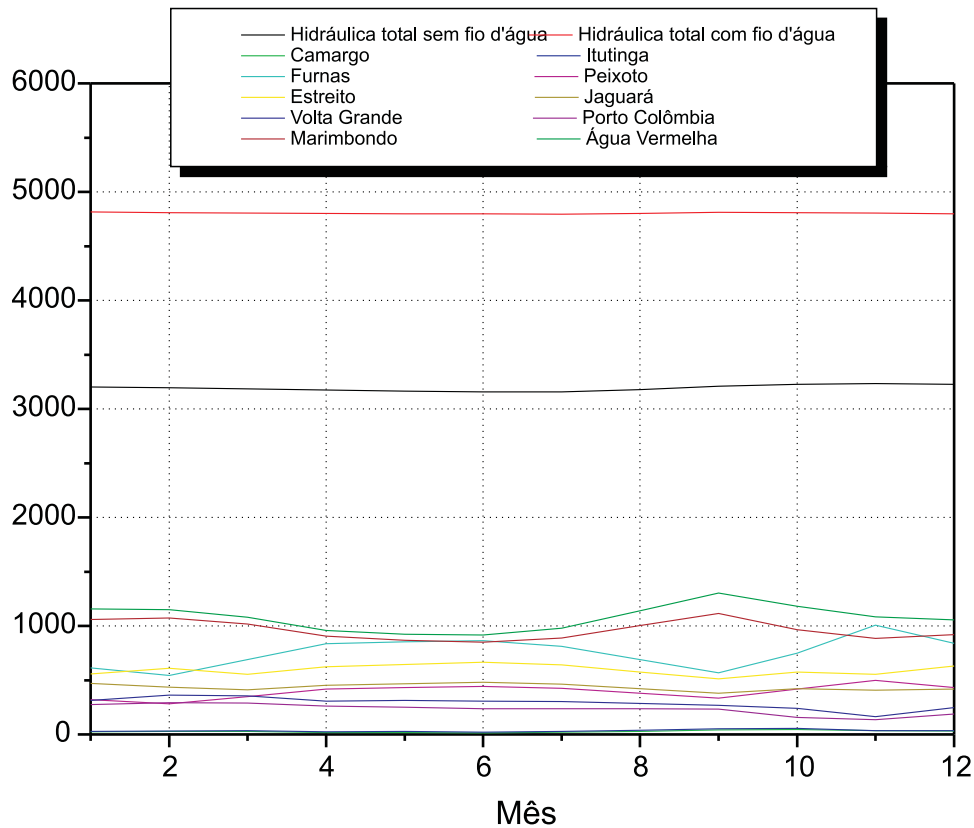

Figura C.16: Estudo Complementar III - Geração hidráulica.

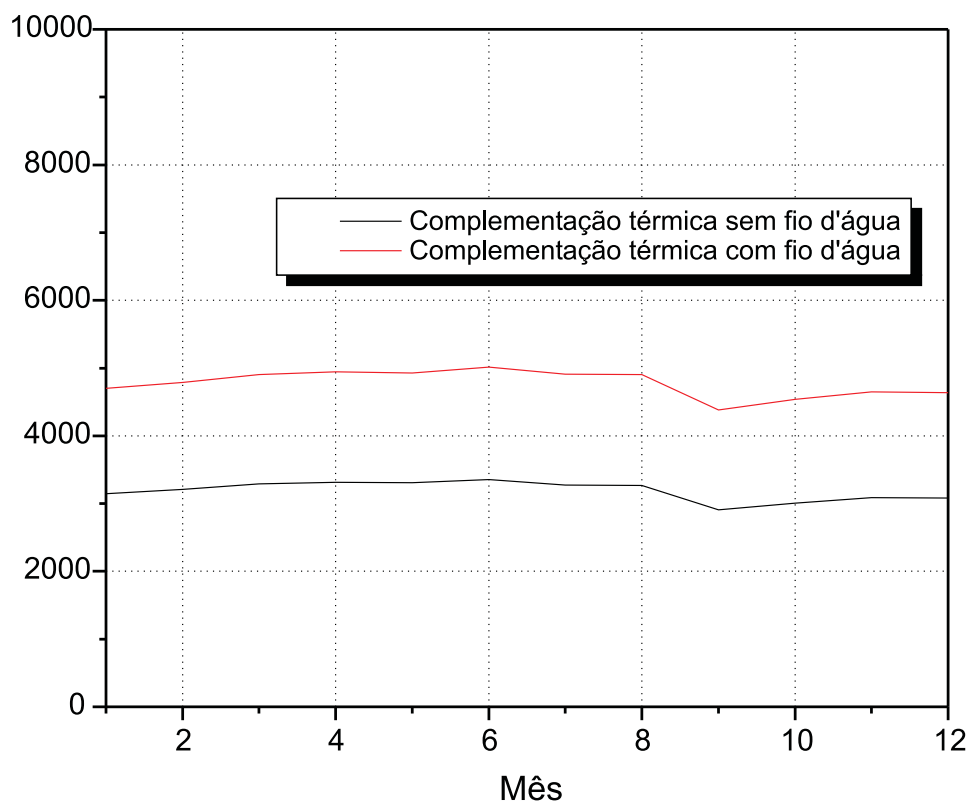

Figura C.17: Estudo Complementar III - Complementação Térmica. 


\section{Referências Bibliográficas}

ACKLEY (1987). ACKLEY, D. (1987). A Connectionist Machine for Genetic Hillclimbing. Kluwer Academic, Boston, United States of America.

ALANDER (2001). ALANDER, J. T. (2001). An Indexed Bibliography of Genetic Algorithms in Power Engineering. ftp: site ftp.uwasa.fi directory cs/report94-1 file gaPowerbib.ps.Z 94-1-Power, University of Vaasa, Vaasa, Finland.

ANEEL (2003). ANEEL (2003). Big - Banco de Informação de Geração, Capacidade de Geração do Brasil. Dados técnicos, Agência Nacional de Energia Elétrica, www.aneel.gov.br.

BAZARAA \& SHETTY (1979). BAZARAA, M. S. \& SHETTY, C. M. (1979). Nonlinear Programming - Theory and Algorithms, volume 1. John Wiley \& Sons, Inc., United States of America.

BEASLEY et al. (1993). BEASLEY, D., BULL, D. R., \& MARTIN, R. R. (1993). An Overview of Genetic Algorithms: Part 1, Fundamentals. Technical Report 15(2), University of Cardiff.

BEASLEY et al. (1993b). BEASLEY, D., BULL, D. R., \& MARTIN, R. R. (1993). An Overview of Genetic Algorithms: Part 2, Research Topics. Technical Report 15(4), University of Cardiff.

BELLMAN (1962). BELLMAN, R. E. (1962). DynamicProgramming. Princeton University Press, Princeton - N.J.

CARNEIRO (1991). CARNEIRO, A. A. F. M. (1991). Contribuição ao Planejamento da Operação Energética de Sistemas Hidrotérmicos de Potência. Tese de Doutoramento, Faculdade de Engenharia Elétrica, Universidade Estadual de Campinas, Campinas. 
CARNEIRO \& BOND (1990). CARNEIRO, A. A. F. M. \& BOND, P. S. (1990). A Large Scale Application of an Optimal Deterministic Hydrothermal Scheduling Algorithm. IEEE Transactions on Power Systems, 5(1):204-211.

CARNEIRO \& MONTANHA (1997). CARNEIRO, A. A. F. M. \& MONTANHA, J. (1997). Estudo da Operação Ótima de Usinas Hidroelétricas através de Autovalores da Matriz Hessiana. XVIII CILAMCE - Congresso Íbero Latino Americano de Métodos Computacionais em Engenharia, II:887-894.

CARNEIRO et al. (1988). CARNEIRO, A. A. F. M., SOARES, S., \& BOND, P. S. (1988). Modelling and Optimization of Hydrothermal Generation Scheduling. VII Congresso Brasileiro da Operação de Sistemas Hidrotérmicos de Potência, 2:823-829.

CARNEIRO \& ZAMBON (1997). CARNEIRO, A. A. F. M. \& ZAMBON, K. L. (1997). Operação de Reservatórios para Geração de Energia Elétrica - Um Eficiente Método Computacional Alternativo. XVIII CILAMCE - Congresso Íbero Latino Americano de Métodos Computacionais em Engenharia, III:1499-1506.

CARVAlhO (1986). CARVAlHO, M. F. H. (1986). Modelos de Fluxo em Redes Aplicados a Sistemas de Energia Elétrica. Tese de Doutoramento, Faculdade de Engenharia Elétrica, Universidade Estadual de Campinas, Campinas.

CARVAlHO et al. (1987). CARVAlHO, M. F. H., CARNEIRO, A. A. F. M., \& SOARES, S. (1987). A Temporally expanded Arborescence Algorithm. VIII Congresso Latino Americano e Ibérico sobre Métodos Computacionais para Engenharia, A:423-437.

CHANG \& CHEN (1998). CHANG, H.-C. \& CHEN, P.-H. (1998). Hydrothermal Generation Scheduling Package: A Genetic Based Approach. IEE Proceeding Generation Transmission Distribuition, 145(4):451-457.

CHEN \& CHANG (1996). CHEN, P.-H. \& CHANG, H.-C. (1996). Genetic Aided Scheduling of Hydraulically Coupled Plants in Hydro-Thermal Coordination. IEEE Transactions on Power Systems, 11(2):975-981.

CICOGNA (1999). CICOGNA, M. A. (1999). Modelo de Planejamento da Operação Energética de Sistemas Hidrotérmicos a Usina Individualizada Orientado por Objetos. Tese de Mestrado, Universidade de Campinas - Faculdade de Engenharia Elétrica e de Computação, Campinas, São Paulo. 
CICOGNA \& SOARES (2003). CICOGNA, M. A. \& SOARES, S. (2003). Um Sistema de Suporte à Decisão para o Planejamneto e a Programação da Operação de Sistemas Hidrotérmicos de Potência. XVII SNPTEE - Seminário Nacional de Produção e Transmissão de Energia Elétrica.

DAVID (1991). DAVID, L. (1991). Handbook of Genetic Algorithms. Van Nostrand Reinhold, New York, United States of America.

DAVID CORNE \& GLOVER (1999). DAVID CORNE, M. D. \& GLOVER, F. (1999). New ideas in optimization, volume 1. David Hatter, McGraw-Hill, Great Britain at the University Press, Cambridge.

GALVÃO \& VAlEnÇA (1999). DE OLIVEIRA GALVÃO, C. \& VALENÇA, M. J. S. (1999). Sistemas Inteligentes - Aplicações a recursos Hídricos e Ciências Ambientais, volume 1. ABRH - Editora da Universidade - UFRGS, Porto Alegre RS.

COElHO (2003). DOS SANTOS COELHO, L. (2003). Fundamentos, Potencialidades e Aplicações de Algoritmos Evolutivos. Notas em matemática aplicada, SBMAC Sociedade Brasileira de Matemática Aplicada e Computacional, São Carlos.

DURAN et al. (1985). DURAN, H., PUECH, C., DIAZ, F., \& SANCHEZ, G. (1985). Optimal Operation of Multireservoir Systems Using an Aggregation-Decomposition Approach. IEEE Transactions on Power Apparatus and Systems, PAS-104(8):20862092.

EIA (2001). EIA (2001). World Hydroelectricity Installed Capacity. U. s. department of energy - table 6.4h, Energy Information Administration, www.eia.doe.gov.

FORTUNATO et al. (1985). FORTUnATO, L. A. M., NETO, A., BARRETO, L. A. L., \& FERREIRA, C. (1985). Operation Planning Studies of the Brazilian Generation System. IFAC Symposium on Planning and Operation of Eletric Energy Systems, pages 193-200.

GEN \& CHENG (1989). GEN, M. \& CHENG, R. (1989). Genetic Algorithms and Enginneering Design. Reading. MA., Addison Wesley, United States of America.

GOLDBERG (1997). GOLDBERG, D. E. (1997). Genetic Algoritmms in Search Optimization and Machine Learning. John Wiley \& Sons, United States of America. 
GREWAL \& WILSON (2000). GREWAL, G. \& WILSON, T. (2000). An Enhanced Genetic Algorithm for Solving the High-Level Synthesis Problems of Scheduling, Allocation, and Binding.

HAUP \& HAUP (1998). HAUP, R. L. \& HAUP, S. E. (1998). Practical Genetic Algorithms, volume 1. Wiley-Interscience - John Wiley \& Sons.

HE et al. (2000). HE, J., XU, J., \& YAO, X. (2000). Solving Equations by Hybrid E volutionary Computation Techniques. IEEE Transactions on Evolutionary Computation, 4(3):295-303.

HOLLAND (1992). HOLLAND, J. H. (1992). Adaptation in Natural and Artificial Systems, volume 1. Bradford Books; Reprint edition.

JONGEPIER (1996). JONGEPIER, A. G. (1996). Artificial Neural Networks Applied to Power Systems, volume 1. KEMA, The Netherland.

KADOWAKI (1995). KADOWAKI, M. (1995). Simulação da Operação de Sistemas Hidroelétricos de Potência a Usinas Individualizadas com Regras Otimizadas. Tese de Mestrado, Escola de Engenharia de São Carlos, Universidade de São Paulo, São Carlos, São Paulo.

KARR et al. (1998). KARR, C. L., WECK, B., \& FREEMAN, L. M. (1998). Solutions to Systems of Nonlinear Equation via a Genetic Algorithm. Engineering Applications on Artificial Intelligence, 2(11):369-375.

WONG \& WONG (1996). KIT P WONG \& WONG, S. Y. W. (1996). Combined Genetic Algorithm/Simulated Annealing/Fuzzy Set Approach to Short-Term Generation Scheduling with Take-or-Pay Fuel Contract. IEEE Transactions on Power Systems, 11(1):128-136.

LEITE (1999). LEITE, P. T. (1999). Um Algoritmo Genético para o Planejamento de Sistemas Hidroelétricos. Tese de Mestrado, Escola de Engenharia de São Carlos, Universidade de São Paulo, São Carlos, São Paulo.

LEITE et al. (2002). LEITE, P. T., CARNEIRO, A. A. F. M., \& CARVALHO, A. C. P. L. F. (2002). Aplicação de Algoritmos Genéticos na Determinação da Operação Ótima de Sistemas Hidrotérmicos de Potência. XIV Congresso Brasileiro de Automática. 
LEITE et al. (2002b). Leite, P. T., CARneiro, A. A. F. M., \& CARVAlhO, A. C. P. L. F. (2002). Energetic Operation Planning Using Genetic Algorithms. IEEE Transactions on Power Systems, 17(1):173-179.

LEWIS (2001). LEWIS, R. (2001). Human Genetics - Concepts and Applications, volume 1. McGraw-Hill.

LYRA et al. (1984). LYRA, C., TAVARES, H., \& SOARES, S. (1984). Modelling and Optimization of Hydrothermal Generation Scheduling. IEE Transaction on Power Apparatus and Systems, PAS-103(8):2126-2133.

MACIEIRA et al. (2003). MACIEIRA, M. E. P., MARCATO, R. M., \& MARCATO, A. L. M. (2003). Comparação entre Abordagem Estocástica e Determinística no Planejamento da Operação de Médio Prazo de Sistemas Hidrotérmicos Interligados. XVII SNPTEE - Seminário Nacional de Produção e Transmissão de Energia Elétrica.

MADAN \& BOLLINGER (1997). MADAN, S. \& BOLLINGER, K. E. (1997). Application of Artificial Intelligence in Power Systems. Eletric Power Systems Research, 41:117-131.

MAE (2002). MAE (2002). Processo de Utilização dos Modelos de Otimização na Formação do Preço do MAE. Apendice d, Mercado Atacadista de Energia Elétrica, www.mae.org.br.

MANTAWY et al. (1999). MANTAWY, A. H., ABDEL-MAGID, Y. L., \& SELIM, S. Z. (1999). Integrating Genetic algorithms, Tabu Search, and Simulated annealing for the Unit Commitment Problem. IEEE Transactions on Power Systems, 14(3):829836.

MARTINEZ (2001). MARTINEZ, L. (2001). Política de Controle Malha Fechada e Malha Aberta no Planejamneto da Operação Energética de Sistemas Hidrotérmicos. Tese de Doutoramento, Faculdade de Engenharia Elétrica, Universidade Estadual de Campinas, Campinas.

MASON et al. (1998). MASON, R. L., GUNST, R. F., \& HESS, J. L. (1998). Statistical Design and Analysis of Experiments, volume 1. John Wiley \& Sons. 
MATSUMOTO \& NISHIMURA (1998). MATSUMOTO, M. \& NISHIMURA, T. (1998). Mersenne Twister: A 623-Dimensionally Equidistributed Uniform Pseudo-Random Number Generator. ACM Transactions on Modeling and Computer Simulation, pages $3-30$.

MENDES (1997). MENDES, E. F. (1997). Projeto Evolucionário de Redes Neurais Artificiais para Avaliação de Crédito Financeiro. Tese de Mestrado, Instituto de Ciências Matemáticas e de Computação, São Carlos, São Paulo.

MENDES et al. (1989). MENDES, M. R., FILHO, N. U. C., \& BRANDAO, J. P. L. (1989). Origem da vida, Genética e Evolução. São Paulo Indústria Gráfica e Editora S/A.

MICHALEWICZ et al. (2000). MICHALEWICZ, Z., BAECK, T., \& FOGEL, D. B. (2000). Evolutionary Computation: Basic Algorithms and Operators, volume 1. Institute of Physics, London.

MICHALEWICZ et al. (1996). MICHALEWICZ, Z., DASGUPTA, D., RICHE, R. G. L., \& SCHOENAUER, M. (1996). Evolutionary Algorithms for Constrained Engineering Problems. Computers $\& 3$ Industrial Engineering Journal, 30(2):851-870.

MIRANDA et al. (1998). MIRANDA, V., SRINIVASAN, D., \& PROENCA, L. M. (1998). Evolutionary Computation in Power Systems - Example 2: Genetic algorithms in Hydrothermal operation Planning. Eletrical Power $\&$ energy Systems, 20(2):93-97.

MONTGOMERY (1984). MONTGOMERY, D. C. (1984). Design and analysis of experiments, volume 1. John Wiley \& Sons, New York.

MORETTIN \& BUSSAB (1984). MORETTIN, P. A. \& BUSSAB, W. O. (1984). Métodos Quantitativos para Economistas e Administradores, volume 1. Atual Editora LTDA.

PEREIRA (1985). PEREIRA, M. V. (1985). Optimal Scheduling of Hydrothermal Systems - An Overview. IFAC Symposium on Planning and Operation of Eletric Energy Systems, pages 1-9.

PEREIRA et al. (1987). PEREIRA, M. V., CUNHA, S. H. F., TERRY, L. A., \& MOSSE, A. (1987). Modelos Computacionais para Planejamento e Operação de Sistemas Hidrotérmicos de Grande Porte. SBA: Controle de Automação, 1(1):31-41. 
RABELO \& OCHI (1996). RABELO, P. G. \& OCHI, L. S. (1996). Um Novo Algoritmo Genético Híbrido para o Problema do Caxeiro Viajante com Grupamento. III Simpósio Brasileiro de Redes Neurais, 1:83-90.

REEVES (1993). REEVES, C. R. (1993). Modern Heuristic Techniques for Combinatorial Problems. John Wiley \& Sons, Great Britain.

REZENDE (2003). REZENDE, S. O. (2003). Sistemas Inteligentes - Fundamentos e Aplicações, volume 1. Manole, Bariri - SP.

RODRIGUES et al. (2003). RODRIGUES, L. G. L., CARNEIRO, A. A. F. M., \& DA COSTA, G. R. M. (2003). O Planejamento da Operação de Curto-Curtíssimo Prazo com Acoplamento Eletro-Energético Utilizando FPOCA. V Congresso Latino-Americano de Geração e Transmissão de Energia Elétrica.

ROSENTHAL (1980). ROSENTHAL, R. E. (1980). Status of Optimization Models for the Operation of Multireservoir Systems with Stochastic Inflows and Nonseparable Benefits. Research Reporter 75, The University of Tennessee, Water Resources Research Center.

SALOMON (1998). SALOMON, R. (1998). Evolutionary Algorithms and Gradient Search: Similarities and Differences. IEEE Transactions on Evolutionary Computation, $2(2): 45-55$.

SCHLICK (1994). SCHLICK, C. (1994). Fast Alternatives to Perlin's Bias and Gain Functions. Graphics Gems IV, pages 401-403.

SILVA (2001). SILVA, E. L. (2001). Formação de Preço em Mercados de Energia Elétrica. Editora Sagra Luzzatto.

SOARES (1987). SOARES, S. (1987). Planejamento da Operação de Sistemas Hidrotérmicos. SBA: Controle de Automação, 1(2):122-131.

SOARES \& CARNEIRO (1991). SOARES, S. \& CARNEIRO, A. A. F. M. (1991). Optimal Operation of Reservoirs for Electric Generation. IEEE Transactions on Power Delivery, 6(3):1101-1107.

SPEARS et al. (1993). SPEARS, W. M., JONG, K. A. D., BäCK, T., FOGEL, D. B., \& DE GARIS, H., editors (1993). An Overview of Evolutionary Computation, volume 667. 
URDEnEtA et al. (1999). URDEnETA, A. J., GóMEZ, J. F., SORRENTINO, E., FLORES, L., \& DIAZ, R. (1999). A Hybrid Genetic algorithm for Optimal Reactive Power Planning Based Upon Successive Linear Programming. IEEE Transactions on Power Systems, 14(4):1292-1298.

WARWICK et al. (1997). WARWICK, K., EKWUE, A., \& AGGARWAL, R. (1997). Artificial Intelligence Techniques in Power Systems, volume 1. The Institution of Electrical Engineers, United kingdom.

WHITLEY (1993). WHITLEY, D. (1993). A Genetic Algorithm Tutorial. Technical Report CS-93-103, Colorado State University, Fort Collins, CO 80523.

WINSTON (1992). WINSTON, P. H. (1992). Artificial Intelligence, volume 1. AddisonWesley Pub Co.

YANG et al. (1996). YANG, P.-C., YANG, H.-T., \& HUANG, C.-L. (1996). Scheduling Short-term Hydrothermal Generation Using evolutionary Programming Techniques. IEE Proceeding Generation Transmission Distribuition, 143(4):371-376.

ZAMBON (1998). ZAMBON, K. L. (1998). Uma eficiente abordagem Linear na Operação de Reservatórios Para Geração de Energia Elétrica. Tese de Mestrado, Escola de Engenharia de São Carlos, Universidade de São Paulo, São Carlos, São Paulo. 